A INFLUÊNCIA DA BR-153 NO CRESCIMENTO E DESENVOLVIMENTO ECONÔMICO DE ARAGUAÍNA

\author{
LUIZ SOARES CORREIA
}

DISSERTAÇÃO DE MESTRADO EM TRANSPORTES DEPARTAMENTO DE ENGENHARIA CIVIL E AMBIENTAL

FACULDADE DE TECNOLOGIA UNIVERSIDADE DE BRASÍLIA 
UNIVERSIDADE DE BRASÍLIA

FACULDADE DE TECNOLOGIA

DEPARTAMENTO DE ENGENHARIA CIVIL E AMBIENTAL

PROGRAMA DE PÓS-GRADUAÇÃO EM TRANSPORTES

\title{
A INFLUÊNCIA DA BR-153 NO CRESCIMENTO E DESENVOLVIMENTO ECONÔMICO DE ARAGUAÍNA
}

\author{
LUIZ SOARES CORREIA
}

ORIENTADOR: JOSÉ AUGUSTO DE SÁ FORTES

DISSERTAÇÃO DE MESTRADO EM TRANSPORTES

PUBLICAÇÃO: T.DM-005A/2015

BRASÍLIA/DF: ABRIL/2015 
UNIVERSIDADE DE BRASÍLIA

FACULDADE DE TECNOLOGIA

DEPARTAMENTO DE ENGENHARIA CIVIL E AMBIENTAL

\section{A INFLUÊNCIA DA BR-153 NO CRESCIMENTO E DESENVOLVIMENTO ECONÔMICO DE ARAGUAÍNA}

\section{LUIZ SOARES CORREIA}

DISSERTAÇÃO DE MESTRADO SUBMETIDA AO DEPARTAMENTO DE ENGENHARIA CIVIL E AMBIENTAL DA FACULDADE DE TECNOLOGIA DA UNIVERSIDADE DE BRASÍLIA COM PARTE DOS REQUISITOS NECESSÁRIOS PARA OBTENÇÃO DO GRAU DE MESTRE EM TRANSPORTES.

\section{APROVADO POR:}

JOSÉ AUGUSTO ABREU SÁ FORTES, PhD (ENC-UnB) (ORIENTADOR)

PAULO CÉSAR MARQUES DA SILVA, PhD (ENC-UnB) (EXAMINADOR INTERNO)

JOSÉ ROGÉRIO DA COSTA VARGENS FILHO, Doutor (UNIP) (EXAMINADOR EXTERNO)

BRASÍLIA/DF, 27 de ABRIL de 2015. 


\section{FICHA CATALOGRÁFICA}

\section{CORREIA, LUIZ SOARES}

A influência da BR-153 no crescimento e desenvolvimento econômico de Araguaína. [Distrito Federal] 2015.

xvi 136p. 210 x 297 mm (ENC/FT/UnB, Mestre, Transportes, 2015).

Dissertação de Mestrado - Universidade de Brasília. Faculdade de Tecnologia.

Departamento de Engenharia Civil e Ambiental.

1. Construção de rodovia

3. Desenvolvimento econômico

I. ENC/FT/UnB
2. Crescimento econômico

4. Evolução de cidade

II. Título (série)

\section{REFERÊNCIA BIBLIOGRÁFICA}

CORREIA, Luiz Soares. (2015). A influência da BR-153 no crescimento e desenvolvimento econômico de Araguaína. Dissertação de Mestrado em Transportes, Publicação PPGT/ENC. T.DM-005/2015, Departamento de Engenharia Civil e Ambiental, Universidade de Brasília, Brasília, DF, 136p.

\section{CESSÃO DE DIREITOS}

AUTOR: Luiz Soares Correia.

TÍTULO: A influência da BR-153 no crescimento e desenvolvimento econômico de Araguaína.

GRAU: Mestre

ANO: 2015

É concedida à Universidade de Brasília permissão para reproduzir cópias desta dissertação de mestrado e para emprestar ou vender tais cópias somente para propósitos acadêmicos e científicos. $\mathrm{O}$ autor reserva outros direitos de publicação e nenhuma parte dessa dissertação de mestrado pode ser reproduzida sem autorização por escrito do autor.

Luiz Soares Correia

Brasília - DF - Brasil.

luiz0908@hotmail.com 


\section{DEDICATÓRIA}

A minha esposa Lislaine,

Por seu amor, compreensão e apoio.

Ao meu filho Luiz Augusto e minha filha Larissa,

Pelo carinho e por doarem alguns momentos preciosos de suas vidas para que eu pudesse me dedicar a esta Dissertação de Mestrado. 


\section{AGRADECIMENTOS}

O corpo é formado por vários membros, um corpo social por várias pessoas. Assim como no mundo não teríamos como vivermos sozinhos, sozinho jamais concluiria o mestrado. Começo meus agradecimentos pela supremacia divina, Deus, que nos dá sabedoria, a minha amada esposa, Lislaine e amados filhos Luiz Augusto e Larissa que sempre estiveram ao meu lado, orando, incentivando, ajudando e torcendo, aos meus pais Osmar Soares Correia e Francisca Soares da Cruz, por me conduzirem ao caminho da escola, ao meu irmão Pedro que, juntamente com os meus pais, contribuiu com a construção da trilha por onde começamos a dar os primeiros passos rumo ao êxito do resultado da formação adquirida, aos meus irmãos José, Maria e Vicente (in memoriam) que crescemos juntos e construímos o legado que nós e nossos filhos desfrutam.

Ao professor José Augusto, por ter aceitado o meu pedido para que fosse meu Orientador, e sendo muito mais do que orientador, com o seu exemplo, ensinou-me a ser mais tolerante e compreensível às situações difíceis a que as pessoas são submetidas, sem esperar que aconteçam.

Ao Dr. Yugo Okida, Vice Reitor da UNIP e Reitor do UNIPLAN, professora Fabiana, professor Ly Freitas, por terem me incentivado a fazer o mestrado, ao professor Pastor Willy que respeitosamente me recebeu enquanto coordenador do PPGT, ao professor Paulo César por ter dado continuidade aos trabalhos que vinham sendo feitos exemplarmente por seus antecessores e também por ter feito parte de minha banca examinadora, ao professor José Rogério que, além de me incentivar no mestrado, ainda fez parte de minha banca examinadora.

A minha cunhada Luciane e amigos Michelle Arcúrio, Ana Maria, Rodrigo Novaes, Romea, Edwin

Silva, Cleber, Wesley, Andrés Idrobo, Fernando Muñoz, Aldey, Rómea, Juan Pablo, Adilson Indi, que contribuíram nos ajustes do trabalho, no meu preparo para a apresentação, na torcida e orações para que, assim como eles, tivesse êxito na minha dissertação. 


\section{RESUMO}

O cenário socioeconômico de um dado local depende de forças que determinam se ele, de acordo com teorias econômicas, se torna "estacionário" ou "em crescimento". Tal ideia se deu com o crescimento e o desenvolvimento econômico da cidade de Araguaína no Tocantins, a qual possui sua posição geográfica facilitada pela abertura da rodovia federal BR-153 e se encontra à margem desta. Isto reforçou a expansão do capital. Dados históricos e estatísticos intensificam este sistema, à medida que promove a ligação entre esta cidade com outros estados como Pará, Goiás e Rio grande do Sul. Outros aspectos que atestam as implicações trazidas pela construção da rodovia Transbrasiliana à cidade de Araguaína referem-se à organização espacial, à formação do contexto social, especialmente à economia, como ela se formou, aliás, estes fatores já fazem parte de ampla contextualização por publicações constantes de pesquisas científicas, como o Instituto de Pesquisas Econômicas Aplicadas - IPEA, Instituto Brasileiro de Geografia e Estatística - IBGE e outros. No entanto, a análise do viés "transporte" restou como objeto para novas investigações, basta ver, este elemento como promotor socioeconômico que foi determinante para o crescimento e desenvolvimento de Araguaína e, assim sua análise não é fator comum no campo de trabalhos científicos. Esta dissertação objetiva mostrar uma nova reflexão, a partir de uma revisão que propõe os autores que discorrem acerca de fundamentos da Economia, da História, da transformação do território econômico e da importância do tráfego viário, e também da relação entre "a vida dos moradores" em Araguaína e o "poder de mobilidade", facilitado pela abertura dos acessos a esta cidade, através da rodovia "BR-153".

Palavras-Chave: Crescimento e desenvolvimento econômico; Rodovia Transbrasiliana. Araguaína; transporte. 


\begin{abstract}
The socioeconomic setting of a specific area depends on the forces that determine it, according to economic theory; it becomes "stationary" or "growth." This idea occurred to the growth and economic development of Araguaína city in Tocantins, which has its geographical position facilitated by the opening of federal highway BR-153 and it is untouched by this. This reinforced the expansion of capital. Historical and statistical data enhance this system, as it promotes the connection between this city to other states like Pará, Goiás and Rio Grande do Sul. Other aspects implies in the Transbrasiliana highway construction to Araguaína city. In this case, it refers to the spatial organization, the social training context, especially the economy, how it has created. In fact, all of them are related to the whole context involved in the publications of scientific research, such as the Institute of Applied Economic Research - IPEA, the Brazilian Institute of Geography and Statistics - IBGE and others. However, analysis of bias "transport" as a result for a new object investigation; how this element as socioeconomic promoter that was essential to the growth and the development of Araguaína. Thus, their analysis is a not common factor in the area of scientific production. This paper aims to show new thinking, from a review proposed by the authors who talk about fundamentals of economics, history, the transformation of economic territory and the importance of the traffic road, and also, the connection between "residents' lives "in Araguaína and the" mobility of power, "facilitated by opening access to this city by highway" BR-153 ".
\end{abstract}

Keywords: Growth and economic development; Transbrasiliana highway. Araguaína; transportation. 


\section{LISTA DE TABELAS}

Tabela 4.1: Distribuição populacional nas microrregiões do Tocantins ................................... 48

Tabela 4.2: Custo com transportes entre 1968 a 1995 ........................................................ 66

Tabela 4.3: População de Araguaína e outras cidades do Tocantins 1940-2010 ........................ 68

Tabela 4.4: Evolução populacional do município de Araguaína .............................................. 69

Tabela 5.1: PIB Municipal - agropecuária - valor adicionado - preços básicos ......................... 76

Tabela 5.2: Crescimento do número de indústrias - Período 1960/1995.................................. 77

Tabela 5.3: Indústria - valor adicionado - preços básicos ..................................................... 78

Tabela 5.4: Número total de Estabelecimentos ou Unidades Locais de Serviços...................... 79

Tabela 5.5: Serviços - valor adicionado - preços básicos ...................................................... 80

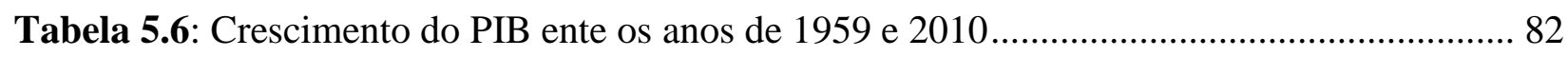

Tabela 5.7: Taxa do desenvolvimento humano entre os anos 1970 a 2010 ............................. 84

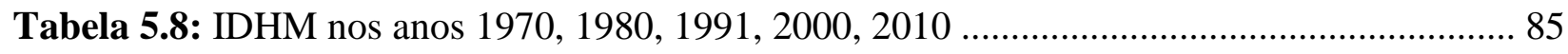

Tabela 5.9: Crescimento da dimensão Renda do IDHM .................................................... 87

Tabela 5.10: Indicadores de ocupação no mercado de trabalho ............................................. 87

Tabela 5.11: Percentual de Apropriação da Renda por Extratos da População do Brasil, Tocantins e alguns municípios do Tocantins, indicadores de 2000 e 2010 ..................................... 88

Tabela 5.12: Número de pessoas segundo faixa de rendimento mensal do estado do Tocantins e

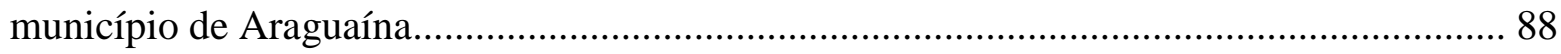

Tabela 5.13: Taxa de ocupação da população com mais de 18 anos........................................ 89

Tabela 5.14: Nível educacional da população ocupada com mais de 18 anos .......................... 89

Tabela 5.15: Crescimento da dimensão Educação do IDHM.................................................. 91

Tabela 5.16: Taxa de analfabetismo da população de 15 anos ou mais de idade por grupos de idade $(\%)$

Tabela 5.17: Taxa de crescimento de frequência escolar e total de estudantes que frequentavam as

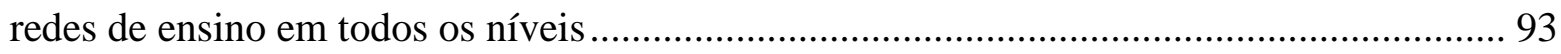

Tabela 5.18: Taxa de frequência a curso superior .......................................................... 93

Tabela 5.19: Índice de Desenvolvimento da Educação Básica de Araguaína............................ 94

Tabela 5.20: Número de Escolas por Etapa de Ensino - Estadual e Municipal de Ensino em Araguaína 95 
Tabela 5.21: Crescimento da dimensão Longevidade do IDHM .......................................... 97

Tabela 5.22: Ranking de Esperança de Vida ao Nascer ......................................................... 97

Tabela 5.23: Coeficiente de Mortalidade Infantil. ................................................................ 98

Tabela 5.24: Sistema de esgotamento sanitário e resíduo sólido ............................................ 99

Tabela 5.25: Sistema de abastecimento de água........................................................... 100

Tabela 5.26: Fornecimento de energia elétrica............................................................... 100

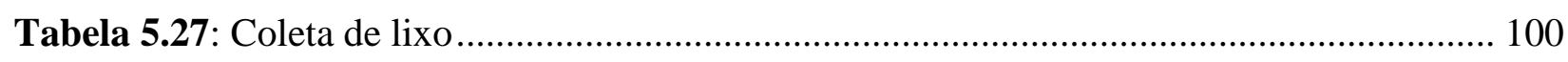

Tabela 5.28: Unidades de Saúde em Araguaína, por Mantenedor ........................................ 101 


\section{LISTA DE FIGURAS}

Figura 2.1: Faixas de Desenvolvimento Humano Municipal ............................................... 25

Figura 3.1: Plano Geral de Viação Nacional - Decreto no 24.497, de 19347, de 1934 ............... 33

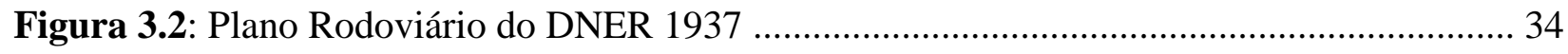

Figura 3.3: Plano Nacional de Viação Rodoviário................................................................. 37

Figura 4.1: Estado do Tocantins e suas Microrregiões ..................................................... 48

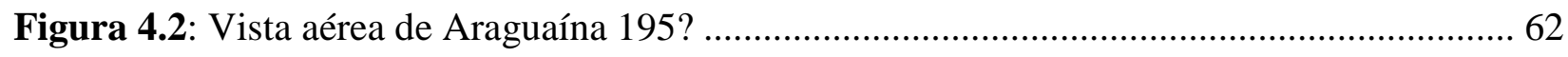

Figura 4.3: Avenida principal de Araguaína 195? ............................................................... 62

Figura 4.4: Araguaína, Capital Regional tipo C. Influência e intermediação com pequenos centros

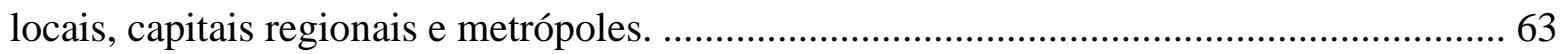

Figura 4.5: Aspectos da infraestrutura rodoviária da região de Araguaína (TO) ....................... 65

Figura 5.1: Raio de Influência do município de Araguaína .................................................. 73

Figura 5.2: Cidades com as quais Araguaína exerce influência e mantém relacionamento ........ 74

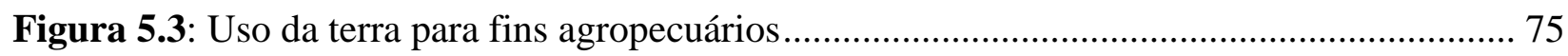

Figura 6.1: Percentual do PIB dos municípios às margens da BR-153 superior ao PIB das cidades

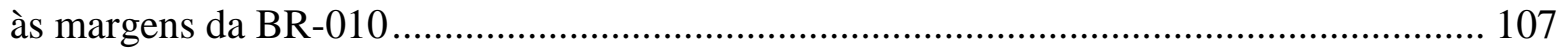

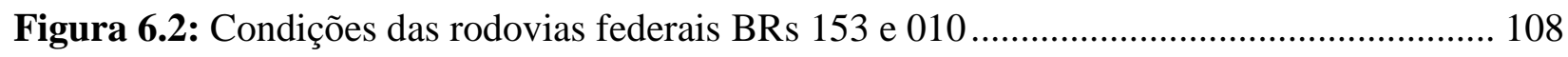

Figura 6.3: Faz referência ao crescimento econômico de antes e depois da BR-153 de Araguaína e cidades correlatas. 112

Figura 6.4: Faz referência à população antes e depois da BR-153, de Araguaína e cidades correlatas

Figura 6.5: Faz referência ao desenvolvimento econômico de antes e depois da BR-153 de Araguaína e cidades correlatas . 114

Figura 6.6: Faz referência a redução dos transportes com a melhoria das vias rodoviárias....... 116

Figura 6.7: PIB Agropecuário de cidades próximas e distantes da BR-153 x 1000 (R\$) ......... 117

Figura 6.8: PIB Indústria de cidades próximas e distante da BR-153 x 1000 (R\$) ................. 118

Figura 6.9: PIB Serviços de cidades próximas e distantes da BR-153 x 1000 (R\$) ................. 119

Figura 6.10: PIB Consolidado de cidades próximas e distantes da BR-153 x 1000 (R\$)......... 120

Figura 6.11: IDHM - Araguaína e cidades correlatas.................................................... 121

Figura 6.12: IDHM Consolidado de cidades prox. e distantes da BR-153 x 1000 (R\$) ........... 122 


\section{LISTA DE EQUAÇÕES}

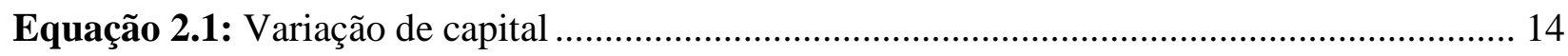

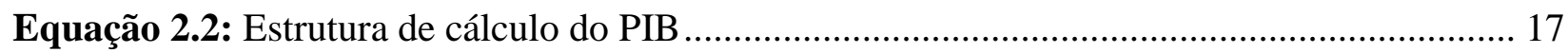

Equação 2.3: Índice de dimensão Longevidade, Educação e Renda ........................................ 23

Equação 2.4: Média geométrica das três dimensões do IDH, Saúde, Educação e Renda............ 23

Equação 2.5: Cálculo geométrico das dimensões do IDHM Saúde, Educação e Renda ............. 26 


\section{LISTA DE ABREVIATURAS E SIGLAS}

ANTT Agência Nacional de Transportes Terrestres

ACIARA Associação Comercial e Industrial de Araguaína

ASCOM Assessoria de Comunicação da Prefeitura Municipal de Araguaína

CELTINS Companhia Energética do Estado do Tocantins

CIMBA Companhia Industrial e Mercantil da Bacia Amazônica

CPDS Comissão de Políticas de Desenvolvimento Sustentável

DERTINS Departamento de Estradas e Rodagens do Estado do Tocantins

DNIT Departamento Nacional de Infraestrutura de Transportes

DNER Departamento Nacional de Estradas e Rodagens

EXPOARA Exposição Agropecuária de Araguaína

FACDO Faculdade Católica Dom Orione

FAHESA Faculdade de Ciências Humanas, Econômicas e da Saúde de Araguaína

FENARA Feira de Negócios das Micro e Pequenas Empresas de Araguaína

FUNAI Fundação Nacional do Índio

FPM Fundo de Participação dos Municípios

GEO Global Environment Outlook

IBAMA Instituto Brasileiro do Meio Ambiente e dos Recursos Naturais Renováveis

IBGE Instituto Brasileiro de Geografia e Estatística

IDEB Índice da Educação Básica

IDH Índice de Desenvolvimento Humano

IDHM Índice de Desenvolvimento Humano Municipal

INEP Instituto Nacional de Estudos e Pesquisas Educacionais Anísio Teixeira

IPEA Instituto de Pesquisa Econômica Aplicada

IPRS Índice Paulista de Responsabilidade Social

ITPAC Instituto Tocantinense Presidente Antônio Carlos

MEC Ministério da Educação

ONU Organização das Nações Unidas

PAR Planos de Ações Articuladas

PIB Produto Interno Bruto

PNUD Programa das Nações Unidas para o Desenvolvimento 
PNV Plano Nacional de Viação

RODOBRÁS Rodovia Belém-Brasília

SBT Sistema Brasileiro de Televisão

SEBRAE Serviço Brasileiro de Apoio às Micro e Pequenas Empresas

SEPLAN-TO Secretaria do Planejamento do Estado do Tocantins

SNV Sistema Nacional de Viação

SALTE Conjunto de programas econômicos e sociais focados na Saúde, Alimentação, Transporte e Energia

SANEATINS Companhia de Saneamento do Tocantins

SPVEA Plano de Valorização Econômica da Amazônia

TGV Transferência Geográfica de Valor 


\section{SUMÁRIO}

1. INTRODUÇÃ

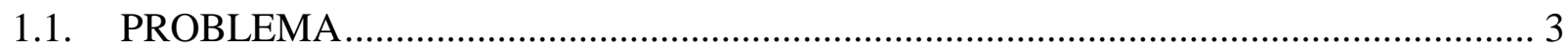

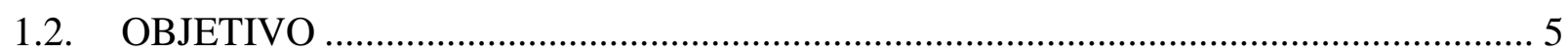

1.2.1. Objetivos Específicos ...................................................................................... 5

1.3. JUSTIFICATIVA DA PESQUISA .................................................................. 5

1.4. ESTRUTURAÇÃO DA METODOLOGIA ............................................................ 6

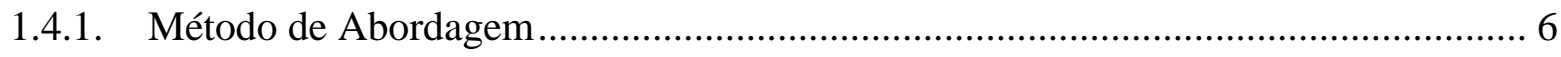

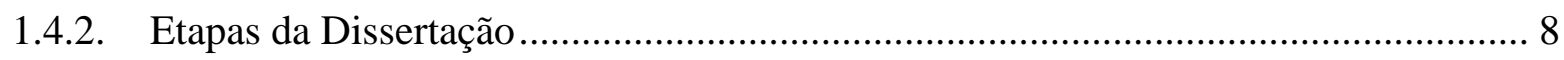

1.5. ESTRUTURA DO DOCUMENTO ............................................................... 9

2. CONCEITOS DE CRESCIMENTO E DESENVOLVIMENTO ECONÔMICO ......... 10

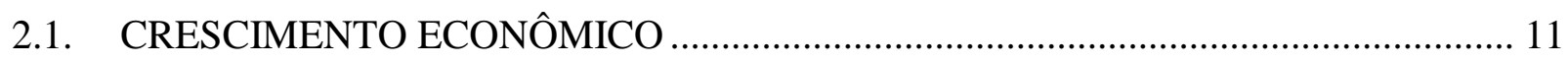

2.1.1. Considerações sobre os modelos de crescimento econômico ............................... 13

2.1.2. Indicadores de crescimento econômico PIB .................................................. 16

2.2. DESENVOLVIMENTO ECONÔMICO ............................................................ 18

2.2.1. Breve histórico da teoria do desenvolvimento econômico.................................... 19

2.2.2. Desenvolvimento econômico: princípios gerativos ........................................ 20

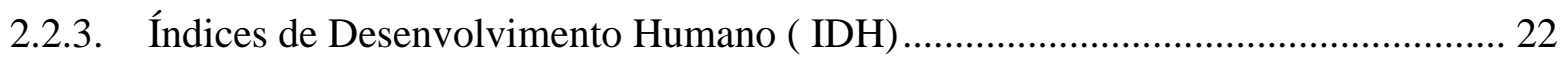

2.2.4. Base de cálculo do IDH e suas respectivas dimensões ..................................... 23

2.2.5. Índice de desenvolvimento humano municipal - IDHM ................................ 24

2.2.5.1. Base de cálculo do IDH municipal e seus respectivos índices ....................... 25

2.2.6. Desenvolvimento Econômico Regional .......................................................... 26

3. PLANOS DE TRANSPORTES NO BRASIL .................................................. 29

3.1. OS PLANOS RODOVIÁRIOS NO BRASIL ................................................... 31 
3.2. INFLUÊNCIAS PRODUZIDAS PELOS TRANSPORTES NO CRESCIMENTO E DESENVOLVIMENTO ECONÔMICO DO BRASIL .................................................. 42

3.3. ATIVIDADE ECONÔMICA VERSUS TRANSPORTES ..................................... 45

4. HISTÓRIA, GEOGRAFIA, TRANSPORTE E CRESCIMENTO POPULACIONAL DE ARAGUAÍNA E CIDADES CORRELATAS .............................................................. 47

4.1. ASPECTOS DAS CIDADES DE GURUPI, PORTO NACIONAL, PEDRO AFONSO E ITACAJÁ, REFERÊNCIA NA COMPARAÇÃO COM ARAGUAÍNA ............ 49

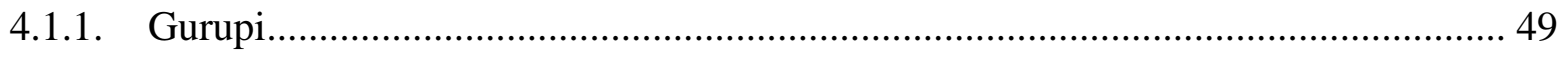

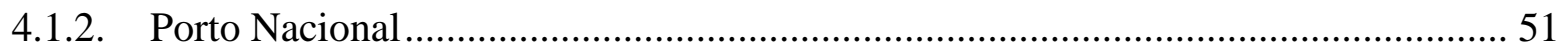

4.1.3. Pedro Afonso ........................................................................................... 54

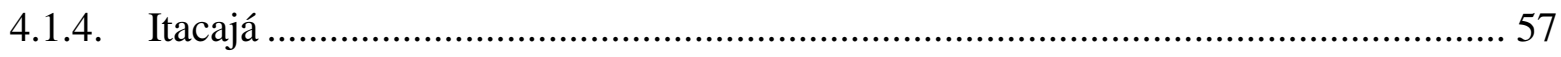

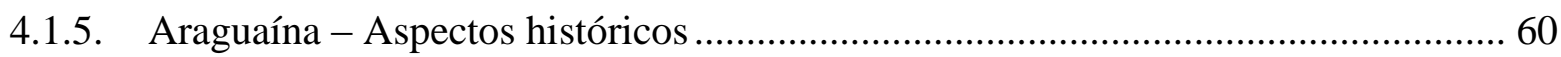

4.1.6. Aspectos das rodovias no município de Araguaína e dos transportes em Araguaína e

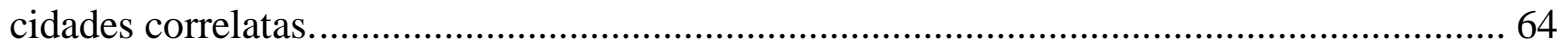

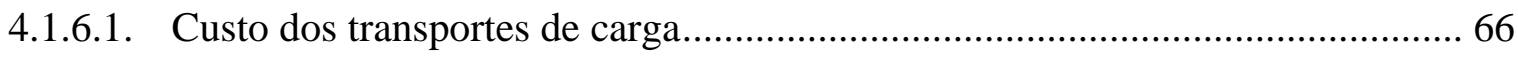

4.1.7. Dinâmica do crescimento populacional de Araguaína e cidades correlatas............ 67

5. ASPECTOS DO CRESCIMENTO ECONÔMICO E DESENVOLVIMENTO ECONÔMICO DE ARAGUAÍNA E CIDADES CORRELATAS ............................................ 72

5.1. ASPECTOS DO CRESCIMENTO ECONÔMICO ............................................... 72

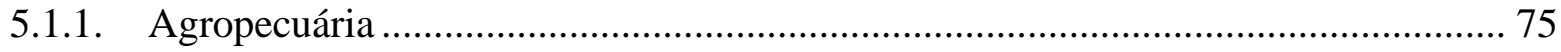

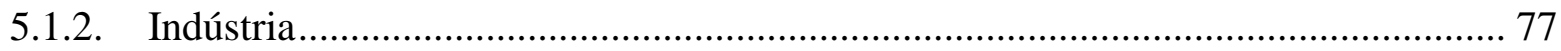

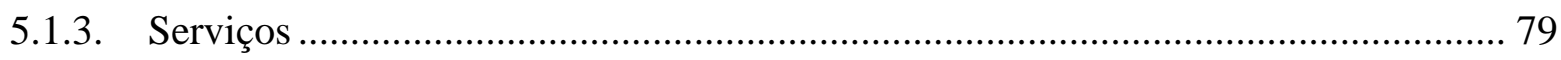

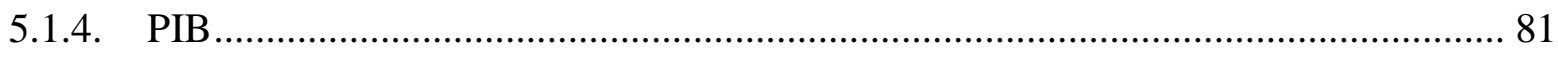

5.2. ASPECTOS DO DESENVOLVIMENTO ECONÔMICO ...................................... 82

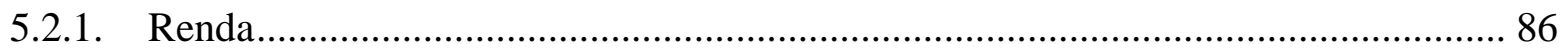

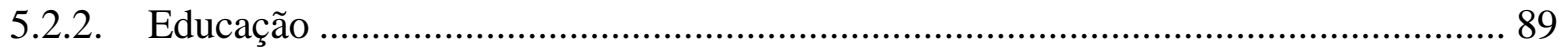


5.2.3. Longevidade

6. ANÁlISE E AVALIAÇÃO DOS IMPACTOS DA IMPLANTAÇÃO DA BR-153 NO DESENVOLVIMENTO E CRESCIMENTO DE ARAGUAÍNA ......................................... 102

6.1. INTRODUÇÃ

6.2. CONTRIBUIÇÕES DA BR-153 À ATIVIDADE ECONÔMICA DA CIDADE DE

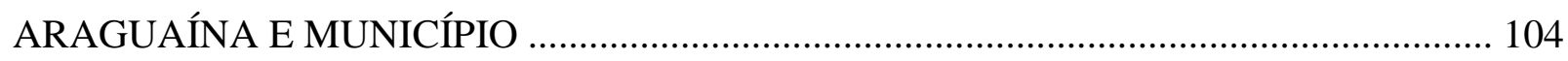

6.2.1. Caracterização da nomenclatura das rodovias ............................................... 105

6.2.2. Características das BR's 153 e 010 que cortam o Estado de Tocantins................. 106

6.2.3. Contribuições à Araguaína advindas da BR-153 ........................................... 111

6.2.4. Relação do Crescimento e Desenvolvimento Econômico das cidades às margens versus cidades que estão distantes da rodovia BR-153 ........................................... 116

7. CONCLUSÕES E RECOMENDAÇÕES .................................................................... 123

7.1. IMPORTÂNCIA E RECOMENDAÇÕES PARA TRABALHOS FUTUROS ........... 127

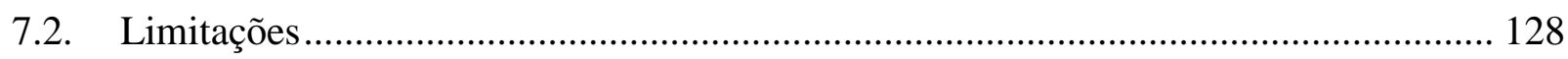

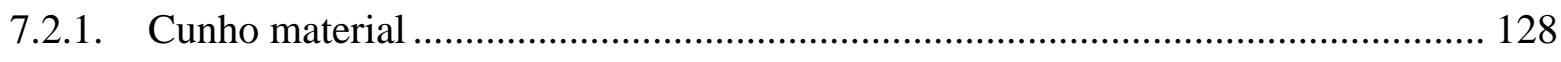

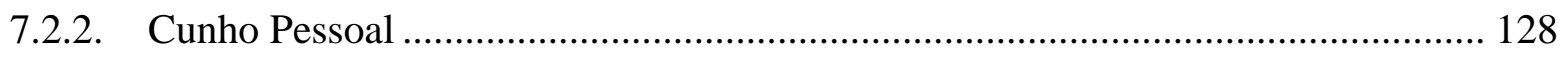

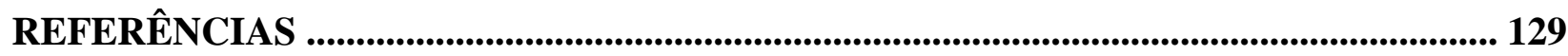




\section{INTRODUÇÃO}

A partir da mensuração de aspectos econômicos e sociais, da quantidade de capital investido pelo governo e indústria, da concentração urbana, sobretudo do nível de bem-estar material da população, é possível prever o crescimento econômico de uma dada região desde o seu início. De acordo com este raciocínio, é possível destacar que, Araguaína no estado do Tocantins, no cenário da expansão capitalista brasileira, tornou-se notória ao nível local, regional e nacional, por ter crescido vertiginosamente após a inauguração da rodovia BR-153, enquanto principal rodovia de integração nacional do Brasil.

Com base em recortes históricos sobre Araguaína e também sobre à rodovia BR-153, constatou-se que, desde o princípio da construção desta rodovia, formaram-se novos povoados e pequenas cidades à sua margem, assim como aumentou o fluxo de pessoas e cresceu em função do que se valeram dela como principal corredor de escoamento para acessar outras regiões, bem como fomentou negócios, investimentos, dentre outras atividades que são próprias da economia.

Embora as razões sejam muitas para utilizar a rodovia BR-153, o maior destaque são a economia e os resultados práticos da promoção dessa acessibilidade junto à sociedade de Araguaína. A BR153 ou Transbrasiliana alcança outras denominações, tais como rodovia Belém-Brasília, rodovia Bernardo Sayão, dependendo do trecho por onde passa.

Entretanto, cabe observar que a análise dos fatores que influenciaram o crescimento e desenvolvimento econômico de Araguaína passa pela contabilização de elementos que norteiam a situação socioeconômica da região em estudo. Assim, isto não pode ser feito aleatoriamente, e sim através de variáveis peculiares ao perfil econômico do campo financeiro, ou seja, destaca-se que, para medir o nível alcançado de bem-estar da população, a quantidade de capital adquirido pelo município e investido pelo governo e indústria, pesam as seguintes referências: Índice de desenvolvimento Humano (IDH), Índice de Desenvolvimento Humano Municipal (IDHM), Produto Interno Bruto (PIB). Tendo como suporte essa quantificação, pode-se concluir o perfil socioeconômico da população da referenciada cidade.

Anteriormente à abertura da rodovia BR-153, Araguaína encontrava-se isolada do resto do Brasil, ou seja, era despovoada, já que as relações territoriais eram restritas aos outros municípios por falta de infraestrutura rodoviária, assim como a sua economia era tímida quando comparada a outros 
tipos de atividades econômicas exercidas em municípios que tinham acessos a outros municípios do Tocantins ou a outros estados. Isto é, tratava-se de uma economia de subsistência, com implicação na mineração e pecuária (SOUSA, 2002).

Por falta da infraestrutura rodoviária, Araguaína não dispunha de meios para promover fluxo de matérias-primas, atrair a circulação de produtos industrializados para a sua delineação territorial, aspecto este que demandou a elaboração de um elo da região de Araguaína ao resto do Brasil. A BR-153 foi capaz de interligar o município às cinco regiões do Brasil.

Acrescenta-se que outro ponto justificador da precariedade socioeconômica vista em Araguaína antes da rodovia BR-153, é com relação aos requisitos promotores do desenvolvimento econômico, ou seja, há necessidade de se investir em infraestrutura diretamente nos setores considerados estratégicos para garantir sua competitividade frente aos outros estados. Em outras palavras, a abertura de caminhos é uma condição primária para consolidar o desenvolvimento de qualquer região, tendo em vista que aumenta a complexidade da produção e o crescimento da atividade econômica e dessa forma, demandando rodovias com traçados retificados, com vistas a garantir maior velocidade e segurança no transporte.

Desde a logística de funcionamento da rodovia BR-153 iniciou-se a implementação das dinâmicas socioeconômicas em Araguaína, pois às margens da então rodovia, foram se estruturando diversas cidades, consolidando a lógica territorial e ações advindas da urbanização na exploração do espaço territorial. Dentre as cidades que se formaram ao longo do trecho da rodovia, destacam-se: Araguaína, Colinas de Goiás (atualmente Colinas do Tocantins), Guaraí, Miranorte, Paraíso do Norte (atualmente Paraíso do Tocantins), Gurupi, Alvorada, dentre outras.

Centraliza-se como ideia primordial, para o presente estudo, que, em face ao surgimento da rodovia ao cenário econômico da região de Araguaína, fora incorporado a economia nacional, pois esta mesma rodovia atuou, conforme dados históricos, de forma consensual para toda a literatura que trata da ligação entre a rodovia BR-153 a cidade de Araguaína, exportador de matérias-primas e, importador de produtos industrializados (AQUINO, 2002).

A ocupação urbana de Araguaína ocorreu facilitada pela rodovia BR-153 pois, de acordo com algumas análises históricas, ao se avaliar como o espaço territorial estava organizado, constatou- 
se uma ocupação incipiente, tanto que as construções eram rudimentares em meados da década de 1950. Posteriormente, a organização espacial, da economia, condicionou-se à pavimentação da rodovia Belém-Brasília (GASPAR, 2002).

Oportunamente, diante da dinâmica territorial provocada pela abertura da rodovia BR-153, a história descreveu a vinda de imigrantes para a cidade de Araguaína, os investimentos de pessoas provenientes do Sul/Sudeste; sobretudo, verificou-se o processo de expansão tanto econômico quanto populacional.

Ressalta-se que, paralelamente à construção da rodovia, deve-se considerar que o governo desenvolveu uma política governamental visando investir intensamente no espaço da cidade de Araguaína. Prova dessa preocupação governamental está em que, nos anos de 1970 e 1980, investimentos da SUDAM em todo o Tocantins mostram-se relevantes (GASPAR, 2002).

A lógica entre o crescimento e desenvolvimento econômico de Araguaína e a construção da rodovia está nos fluxos de pessoas facilitado pela rodovia, que por sua vez, deu à cidade maior acesso da parte externa.

\subsection{PROBLEMA}

Não obstante, o desejo da população proveniente das cidades com baixos índices de crescimento e desenvolvimento econômicos em mitigar sua condição socioeconômica, ainda são insipientes as políticas públicas capazes de corrigir tais disparidades econômicas. A partir de uma análise acerca da situação econômica das cidades brasileiras, constata-se que o Índice de Desenvolvimento Humano (IDH), isto é, o que mede o estado de saúde, educação e renda da população, melhorou com a implantação de programas de tutela estatal em que se destacam programas de bolsas sociais, ao passo que o Produto Interno Bruto (PIB) - índice que mede o acúmulo de riqueza de uma região ou país padece por falta de investimentos em infraestrutura.

Essas mesmas disparidades econômicas podem ser constatadas especificamente em dois contextos da história da cidade de Araguaína, quais sejam, antes e depois da abertura de seus acessos. Observam-se acentuadas diferenças econômicas e sociais em ambos os momentos, basta ver que não possuem suficiência econômica em todos os aspectos. Por exemplo, nota-se que, após a abertura do acesso a Araguaína, através BR-153, houve um crescimento populacional de forma 
exponencial e, portanto, está dotada de hospitais públicos e privados com várias especialidades médicas, escolas e universidades, pólo industrial com dezenas de indústrias, comércio e prestação de serviço em alta e, se comparado com outros municípios do estado do Tocantins, um nível satisfatório de emprego e renda das pessoas.

Antes da rodovia BR-153, Araguaína padece com as precárias condições de vida; mantém-se estagnada sob vários aspectos socioeconômicos: baixíssimo índice de crescimento populacional, possui apenas uma indústria e poucos comércios. Atualmente possui também várias indústrias, intensa atividade na prestação de serviços e uma extensa agropecuária moderna. Em 2010 a cidade apresentou o segundo maior PIB do estado num valor de $\mathrm{R} \$ 1.922 .814,00$, PIB per capita de R $\$$ 12.774,48 e um IDH médio de 0,752 considerado alto, conforme faixas do desenvolvimento humano disponibilizado pelo (PNUD, O que é o RDH, 2014).A maior dimensão deste indicador é a longevidade com $36 \%$ seguido pela Educação e Renda com $32 \%$.

No decorrer desta dissertação, serão apresentados dados desses elementos capazes de demonstrar o status econômico de Araguaína, a partir do final dos anos 50, próximo sua fundação que foi em 1958.

Após a abertura da rodovia BR-153, observa-se que o IDH e o PIB apresentam-se melhores do que anteriormente, visto que Araguaína passa a ter pólo industrial com várias indústrias instaladas, com predominância a agroindústria. Além dessa predominância, onde se destacam laticínios e frigoríficos, existe ainda, como atividade econômica em menor escala, a indústria têxtil. Apesar do setor industrial possuir 285 estabelecimentos industriais, os informais, somados aos não informados, são superiores aos formais em 32\% e, no entanto, geram 1.924 empregos, conforme IBGE (2010).

Conforme dados divulgados em 2012 pela Secretaria de Planejamento do Tocantins (SEPLANTO), o PIB de Araguaína continua sendo o que representa a segunda maior participação econômica no estado, com destaque o setor de serviços com $80 \%$ de participação seguido pela indústria com $17 \%$ e agropecuária com $3 \%$.

Analisar Araguaína antes e depois da abertura de seus acessos através da rodovia é importante, especialmente quando se faz um questionamento quanto à rodovia BR-153: o que mudou no 
município de Araguaína e na vida das pessoas após abertura da rodovia BR-153? Qual a importância da rodovia BR-153 para o crescimento e desenvolvimento econômico de Araguaína?

\subsection{OBJETIVO}

- Demonstrar que a implantação da BR-153 foi fundamental para o desenvolvimento e crescimento de Araguaína.

\subsubsection{Objetivos Específicos}

- Avaliar a influência da rodovia BR-153 no crescimento e desenvolvimento de Araguaína.

- Comparar alguns índices socioeconômicos da cidade de Araguaína, no Estado do Tocantins e fazer a relação do crescimento de Araguaína, antes e depois da construção da rodovia BR-153.

\subsection{JUSTIFICATIVA DA PESQUISA}

A cidade de Araguaína tem em seu bojo histórico perfil econômico crescente, se tomada como ponto de partida para análise a construção da rodovia federal BR-153 iniciada no ano de 1960 e, em seguida seu processo de formação, em seus aspectos socioeconômicos. Por meio da prestação de serviços, comércio, indústria e agricultura, Araguaína mostrou que a abertura desta rodovia federal deu novos rumos à economia local. As transformações no centro urbano do município de Araguaína legitimam a importância da rodovia federal para a cidade; essa importância também pode ser comprovada em seu expressivo crescimento e desenvolvimento econômico devido a evidente política migratória do campo para as cidades, bem como de outras cidades circunvizinhas e de outros estados, ressaltando, dessa forma, a acessibilidade trazida pela rodovia, qual seja, a BR153.

Apesar da rodovia BR-153 fazer interface entre a região norte e o extremo da região sul do país, observa-se, pelos mapas constantes no Departamento Nacional de Infraestrutura de Transportes (DNIT), que a região sul, conjuntamente com a região sudeste, tem maior número de rodovias pavimentadas do que as regiões norte e nordeste.

Vale ressaltar que, conforme dados disponíveis no IBGE, as regiões sul e sudeste também apresentam o PIB maior que o das regiões norte e nordeste, as quais têm menos vias. Contudo, somente a construção de rodovias não justifica o crescimento das cidades, mas está sempre associada à dinamização das atividades econômicas. Constata-se, também, que existem casos em 
que a diferença da soma das riquezas acumuladas, representada pelo PIB de uma região brasileira, é mais que o dobro em relação a outra região, conforme demonstra o IBGE (2010).

Outro ponto a ser observado em relação às regiões com maior número de rodovias é que, não muito diferente do PIB, o PIB per capita das regiões sudeste, centro-oeste e sul é maior que o PIB per capita das regiões norte e nordeste. De acordo com os dados comparativos do PIB a valores correntes, Araguaína, município pertencente a região norte, mesmo tendo PIB per capita abaixo da média nacional, ainda está acima do PIB per capita das regiões norte e nordeste e acima, inclusive, do PIB per capita do estado a que pertence, o Tocantins, segundo IBGE (2010).

Diante das diferenças regionais, na cidade de Araguaína, o enfoque deve ser em torno de um estudo histórico-comparativo da relação Araguaína com a Rodovia Federal BR-153 e influências ocorridas após a sua construção.

Deve-se pensar que, com a construção da BR-153 e integração desta a uma rede de transporte, cuja concepção para a região deve se enquadrar dentro da noção da política de desenvolvimento e crescimento econômico regional com a inclusão uma rede de transporte, embora não seja elemento deste estudo, a cidade venha sair dos modestos índices de crescimento para resultados mais significativos.

Segundo Almeida (2008), quando as diferenças econômicas são mantidas, tem-se a tendência de preservar as interdependências regionais, chegando ao ponto de funcionarem como elementos impeditivos de crescimento econômico, tanto regional quanto nacional. Por essa razão, torna-se necessário adotar mecanismos que atenuem tais desigualdades para que as regiões com menores índices econômicos alcancem níveis consideráveis, de maneira que consigam tornar-se competitivas com as outras regiões com maior nível de crescimento.

\subsection{ESTRUTURAÇÃO DA METODOLOGIA}

\subsubsection{Método de Abordagem}

O método utilizado para a abordagem desta dissertação foi o descritivo-indutivo com uso de série histórica de dados econômicos estatísticos levantados através de pesquisa bibliográfica e de históricos socioeconômicos da cidade de Araguaína e das cidades Gurupi, Itacajá, Pedro Afonso e Porto Nacional, confrontando seu crescimento e desenvolvimento econômico antes e depois da 
construção da BR-153, bem como fazendo comparativo de Araguaína com as cidades e seus recursos de transportes como meio estimulante da economia regional.

O critério para a escolha das cidades usadas na comparação com Araguaína foi baseado na idade das cidades, em fatos históricos da cidade, dos recursos econômicos e modais de transporte em que cada município é servido para o escoamento do excedente produzido, como elemento indutor da economia regional.

Para tal, foram consultadas obras literárias, relatos de pesquisas acerca de dados quantitativos em relação à cidade de Araguaína e as cidades correlatas, assim como aspectos econômicos e sociais constantes de sítios eletrônicos do Governo Federal destinados a elaborar estatísticas e censos.

A idealização deste ocorreu com a observação da discrepância socioeconômica existente entre antes e depois da construção da rodovia BR 153, relativamente à cidade de Araguaína e tais cidades como Itacajá, pouco mais velha do que Araguaína, a qual permanece estagnada sob o ponto de vista capitalista, com modestos indicadores socioeconômicos. Com baixo índice socioeconômico de crescimento populacional chegando às vezes ao decrescimento.

Verificou-se a relação estreita entre Araguaína e a construção da rodovia BR 153, que por sua vez, necessitou de uma análise espaço-temporal em que a dinâmica social e econômica foi formada a partir da existência da rodovia BR-153. O crescimento populacional da cidade de Araguaína foi um dos aspectos observados, uma vez que é sinônimo e motor do desenvolvimento econômico. Mais especificamente, foram abordadas as dinâmicas socioeconômicas estruturadas por influências advindas da logística produzida pela rodovia BR-153, a fim de explicar como esta mesma rodovia foi responsável pelo recorte sociedade/economia.

A partir da integração nacional promovida pela BR-153 foi demonstrada a vivência multiterritorial ocorrida na cidade de Araguaína pois para Dias e Brito (2012), a então rodovia configura-se como um instrumento de território-rede. O contexto de construção da rodovia BR-153 é o cenário escolhido para demonstrar que a rodovia foi a base para o desenvolvimento econômico e social de Araguaína. 


\subsubsection{Etapas da Dissertação}

Primeira Etapa: Levantamento do Referencial bibliográfico constituída por conceitos de crescimento e desenvolvimento econômico através do PIB e IDH.

Segunda Etapa: Levantamento de dados históricos dos transportes no Brasil com suas influências e Dados Históricos de Araguaína e cidades correlatas (antes e depois da construção da Rodovia BR-153).

Terceira Etapa: Coleta de dados dos estatísticos e índices econômicos que compõem o PIB e o IDH de Araguaína e cidade correlatas no período que compreende a construção da rodovia federal BR-153, para consolidação da relação da construção da referida rodovia com o Crescimento e Desenvolvimento Econômico de Araguaína.

Quarta Etapa: Análise dos dados coletados, através de comparação e interpretação das informações à luz das teorias selecionadas para subsidiar a pesquisa e apresentação dos resultados finais.

Quita Etapa: Conclusões e recomendações.

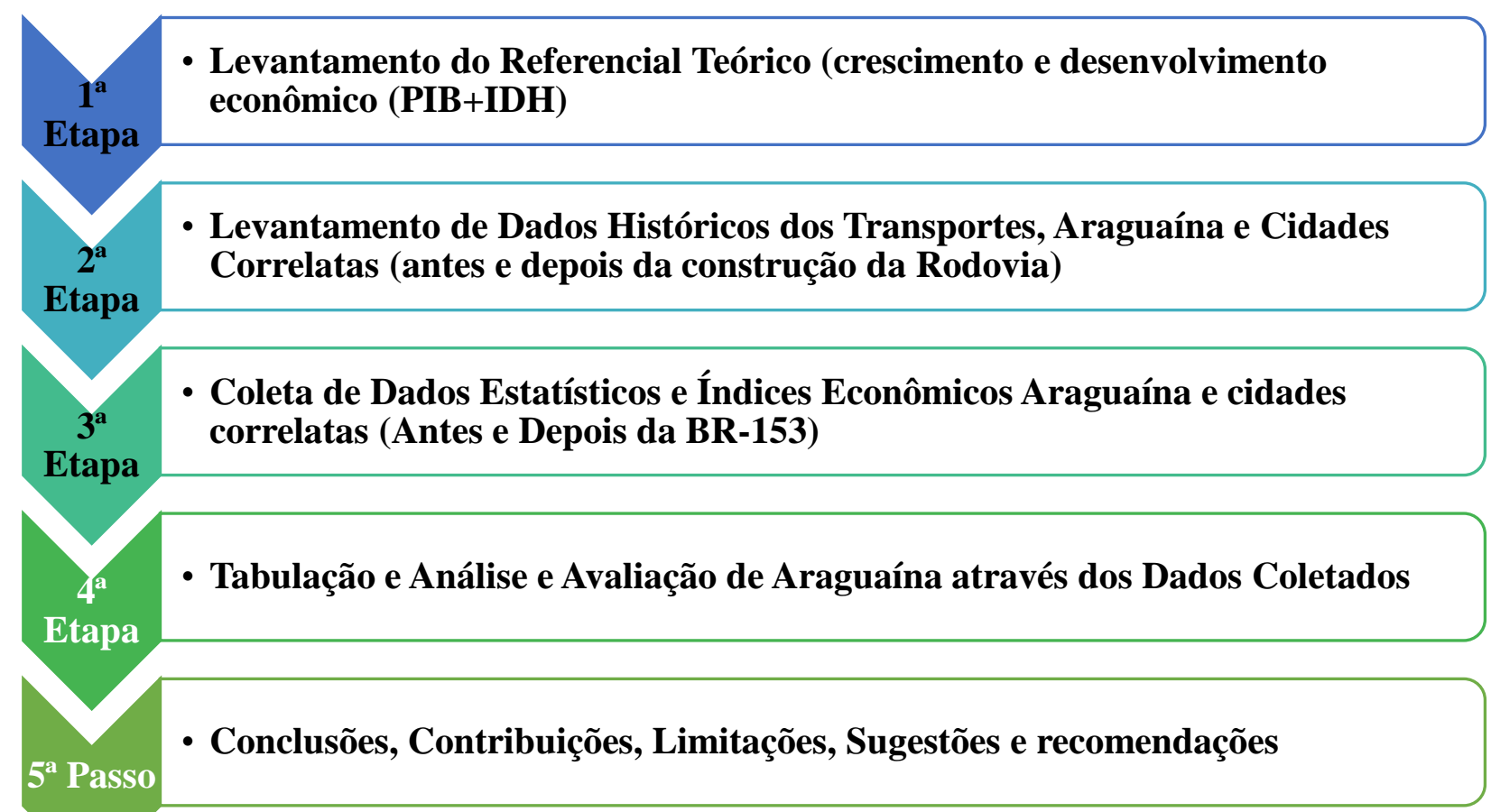




\subsection{ESTRUTURA DO DOCUMENTO}

Esta dissertação divide-se em sete capítulos. O primeiro capítulo é introdutório e tem por finalidade apresentar os parâmetros e o desenvolvimento da pesquisa proposta, apresentando o problema, objetivos, justificativa e síntese da metodologia do trabalho.

O capítulo 2 mostra conceitos de crescimento e desenvolvimento econômico, os quais estão ligados à história da humanidade e também ao processo de industrialização iniciando na Europa no século XVIII e chegando ao Brasil no início do século XX, onde houve muitas limitações. Porém é relevante ressaltar que, para uma discussão mais acadêmica e mais específica, o conceito de "crescimento e desenvolvimento econômico regional" deve ser considerado como ponto crucial e relevante na análise aqui apresentada.

O capítulo 3 apresenta um breve histórico dos planos nacionais relacionados à malha rodoviária brasileira, desde a primeira república (1889-1930) até os dias atuais, fazendo, inclusive, menção ao surgimento da construção da rodovia federal BR-153, bem como o entendimento do valor agregado da infraestrutura de transporte e influência positiva ou negativa produzida na vida das pessoas, no crescimento e desenvolvimento econômico.

O capítulo 4 contextualiza o município de Araguaína e cidades correlatas demonstrando em número seus aspectos históricos, geográficos, transportes, socioeconômicos e populacionais.

Já no capítulo 5, enfatiza-se fatores que foram cruciais para o crescimento e desenvolvimento econômico de Araguaína, onde foram demonstrados em números os dados econômicos e sua relação com o transporte.

O capítulo 6 apresenta a análise dos resultados. Com os dados levantados no capítulo anterior, são analisados os resultados alcançados e identificados os fatores responsáveis pelo crescimento e desenvolvimento de Araguaína. Destacam-se ainda, as contribuições da BR-153 às atividades econômicas do município em referência.

Por fim, o capítulo 7 apresenta as conclusões e recomendações, apoiando-se nos objetivos propostos inicialmente, de forma que respondam às questões problema e elucidem o tema. 


\section{CONCEITOS DE CRESCIMENTO E DESENVOLVIMENTO ECONÔMICO}

O processo de formação do capital está implicado na noção de desenvolvimento econômico e social de um país. Mais especificamente no que trata aos aspectos quantitativos em que pese o PIB. A formação do capital no Brasil esteve atrelada a incentivos governamentais, à importação e exportação de bens de capital ao longo da industrialização, no período compreendido entre 18851945 da historiografia no Brasil. Lembrando que, foi a crise econômica de 1929 que determinou modificação profunda na sociedade através da economia brasileira, isto é, transformou-a em industrial nos anos subsequentes (BARAT, 1991).

Destaque-se também que, com alterações profundas na economia brasileira ocorridas nos anos 1930, o governo priorizou sua política econômica em favor do incremento da renda interna, em lugar das importações de bens de capitais, o que impulsionou a instalação do setor industrial siderúrgico e deu expressividade à expansão dos setores de metalurgia e siderurgia.

Com a expansão industrial e mudanças nas estruturas econômicas, desencadearam-se, dessa forma, novas necessidades para dar suporte a essa nova fase da economia, especialmente a necessidade da requalificação da infraestrutura de transporte para o deslocamento dos bens de consumo e escoamento da produção, assim como o suporte da energia elétrica para alimentação das máquinas nas indústrias e atender às demandas de consumo da sociedade através de bens de consumo oriundos das indústrias.

A produção de energia elétrica ilustrou o processo de industrialização, tendo em vista que a produção desse insumo, conforme nos orienta Barat (1991), nas duas primeiras décadas do século XX aumentou em razão do consumo cada vez maior. Não obstante, esse delineamento da expressiva produção de energia, deve-se considerar a relativa participação das usinas hidroelétricas na geração de energia elétrica.

Barat (2007), ainda fazendo referência ao desenvolvimento industrial, acrescenta que:

Com a proliferação industrial cada vez mais consolidada, o consumo tornou-se demasiado em relação à produção industrial, desencadeando a emancipação da produção automobilística, tanto que em 1960 esse tipo de indústria tinha 2/3 de sua produção concentrada em veículos de carga leves, médios e pesados.

A teoria de desenvolvimento econômico refere-se à mudança ou crescimento que produz aumento 
nos rendimentos per capita, na produção agrícola, no nível de industrialização ou no comércio exterior de um país. Apesar dos termos crescimento e desenvolvimento econômico serem frequentemente utilizados indistintamente para designar o aumento da renda nacional e per capita, o crescimento mede a evolução quantitativa das variáveis macroeconômicas para justificar como um país cresce economicamente. Deve-se compreender ainda que o desenvolvimento refere-se à variação qualitativa das estruturas econômicas e sociais dos países. A noção de desenvolvimento é frequentemente mais utilizada quando se faz referência aos aspectos humanos, especialmente em países em vias de desenvolvimento.

Milone (1998) afirma que: o crescimento econômico é definido pelo PIB em termos globais e per capita ao logo do tempo. Enquanto que desenvolvimento econômico, segundo ainda Milone,“(...) é um aumento de produção acompanhado de modificação nas disposições técnicas e institucionais, isto é, mudanças nas estruturas produtivas e alocações de insumos pelos diferentes setores da produção".

Avaliar o crescimento e desenvolvimento econômico de um país ou de uma determinada região depende de levantamento de dados comparativos num determinado período de tempo entre as diferenças das estruturas física, organizacional, social, cultural, especificamente das políticas econômicas. Este aspecto foi abordado em um trabalho realizado por Dias e Dias (2007), relativamente a análise econômica dos Estados brasileiros em dependência, a longo prazo, do crescimento da produtividade da distribuição de renda, da melhoria do capital humano.

\subsection{CRESCIMENTO ECONÔMICO}

A sociedade antes do capitalismo, que é um movimento recente, não tinha noção de crescimento econômico, pois vivia em estágios comparativamente estagnados. Era uma sociedade basicamente agrícola, onde os recursos variavam conforme comportamento do tempo dentro da própria sazonalidade, entre boas ou más colheitas nas estações do ano. Se a estação era boa, adquiriam-se mais recursos e acumulavam-se os bens produzidos na terra.

Ao contrário, sofriam as penalidades da escassez dos mantimentos e consumia o excedente das melhores estações ocorridas anteriormente. Outro fator que contribuía na baixa do estoque dos bens adquiridos da terra eram as guerras e as epidemias, que por vezes, impediam o homem de se debruçar sobre a terra, seu bem maior e fonte de riqueza. 
De acordo com Pinto e Fredes (1974), a fisiocracia, escola de pensamento composta por economistas burgueses no século XVIII na França, ficou conhecida pelo trabalho pioneiro e singular de François Quesnay (1694-1774). No Tableau Économique de 1758, Quesnay defendia que a agricultura era a fonte de riqueza da nação como atividade produtiva e, portanto, o aumento das riquezas dependia do aumento da produtividade agrícola. Tal conceito era divergente no mercantilismo inglês, focado no desenvolvimento da indústria e do comércio exterior. Além de ter desenvolvido a indústria, a Inglaterra possuía um forte transporte marítimo competitivo; com base nisso, cresceu economicamente num ritmo muito mais acelerado do que a França.

O capitalismo foi a máquina propulsora capaz de provocar mudanças contínuas tecnológicas e de acumulação de capital que alterou de forma radical as estruturas da sociedade. No século XX, a produção industrial mundial cresceu entre 30 e 40 vezes e, embora a população mundial tenha dobrado, a produção per capita cresceu entre 15 e 20 vezes. Diante dessa realidade emergiu a necessidade em entender como ocorre o crescimento econômico. Milone (2009) enfatiza que, para haver crescimento econômico, deverão existir dois elementos: o primeiro é através da acumulação de capital, por meio do aumento de máquinas, indústrias; da realização de obras de infraestrutura: estradas, energia; e do investimento em recursos humanos; melhor preparação da mão de obra e outros $^{1}$.

Na abordagem da econometria espacial, feita por Vieira (2009), sobre os estudos do crescimento econômico da cidade de São Paulo e outras regiões, revela que estes estiveram, de forma geral, ligados à grande teoria de crescimento econômico das nações, principalmente, aqueles balizados pela literatura econômica do mainstream (termo que designa o pensamento ou gosto corrente da maioria da população, ou seja, ideia que expressa uma característica dominante da literatura). Barro e Sala-i-Martin (2004), que apresentam composições teóricas e discutem sobre os principais conceitos do crescimento econômico propostos no decorrer do século XX, utilizam ferramentas teóricas em discussão no âmbito municipal, nos municípios japoneses; estadual, nos estados norteamericanos e regional, nas regiões europeias. Estes teóricos, em suas análises apresentam os comportamentos observados em cada um desses centros geográficos.

\footnotetext{
${ }^{1}$ Pode se considerar que a visão de Milone sobre crescimento econômico está em consonância com as teorias modernas deste mesmo assunto. Para que a riqueza tenha valor agregado precisa ter investimentos no capital humano.
} 


\subsubsection{Considerações sobre os modelos de crescimento econômico}

Vieira (2009) considera que o crescimento econômico das nações passa pela noção ofertada por economistas clássicos como Adam Smith (1776); David Ricardo (1817); Thomas Malthus (1798); Ramsey (1928); Allyn Young (1928); Frank Knight (1944); Joseph Schumpeter (1934). Ainda, conforme Vieira (2009), fazendo menção a esses economistas, encontram-se os modelos de interpretação das determinantes do crescimento econômico a longo prazo de qualquer nação. Dentro desse contexto, abordado por Vieira e Veríssimo (2009), tais modelos tinham por base a chamada propriedade de convergência, cuja ideia principal era de que para economias com níveis mais baixos de PIB per capita, maiores seriam as taxas de crescimento previstas, sendo essa propriedade associada ao suposto retorno decrescente do capital. Exemplarmente, existe o modelo de Solow-Swan, cujo ápice de seu entendimento está na forma neoclássica da função de produção, em que o processo de acumulação de capital expressa o nível de renda do país.

As ações governamentais também são determinantes nas aplicações dos modelos teóricos do crescimento econômico porque tratam das implicações de políticas públicas que incidem na taxa de crescimento do capital, são elas: taxação, poder de execução das instituições, fornecimento de serviços de infraestrutura, proteção da propriedade intelectual e regulação do comércio internacional e mercados financeiros, dentre outros pontos. Contudo, os modelos teóricos de crescimento econômico até então destacados, dos anos 50 e 60 encontram resistência ao serem aplicados atualmente, em função de ser dada maior ênfase aos estudos empíricos, através do senso comum e das experiências adquiridas.

O governo determina nas políticas econômicas se os investimentos de capitais serão altos ou baixos. Aspecto peculiar quanto às bases de sustentação da visão de Solow é com relação ao equilíbrio dos efeitos do crescimento populacional, que por sua vez, possibilita, acaso se apresente sem medida, menor disponibilidade de capital para atender à população em todas as necessidades. Neste sentido, o investimento sobre estoque de capital, pelo trabalhador, é fator crucial para legitimar o crescimento econômico. Uma das formas de investimento no estoque de capital é a poupança feita por trabalhadores em nível ascendente, e a inclusão do progresso tecnológico (VIEIRA, 2009).

Deve-se considerar que a acumulação do capital físico, com o propósito de crescimento econômico, obedece à atuação do progresso tecnológico, com vistas a contornar os efeitos dos rendimentos 
decrescentes e manter o crescimento do produto per capita. Entretanto, fazer referência da teoria neoclássica produzida por Solow perdeu espaço, nos anos 80, em face de sua impotência diante de aplicações empíricas. Desta forma, entende-se que a inserção tecnológica nos modelos neoclássicos decorre, imperativamente, da diferença entre os retornos privados e sociais do investimento, em que prevalece a constância dos retornos sociais do investimento em detrimento dos efeitos decrescentes do retorno privado.

Principiando com os modelos atuais de teorias que explicam o crescimento econômico, observa-se que a diferença entre os modelos neoclássicos e os vigentes, encontra-se sedimentada na incorporação da determinante da taxa de crescimento em longo prazo no modelo atual, aspecto que define o que se convencionou chamar de "modelos de crescimento endógeno". Sendo que os modelos de crescimento endógeno, os atuais, então, os modelos recentes de crescimento econômico não dependem de variáveis exógenas importantes como tecnologia e população, antes sim, seus retornos do investimento não são necessariamente decrescentes. Mas se deve aceitar que os benefícios externos do capital humano atuam como papel crucial no processo da economia porque evita a tendência de retornos decrescentes à acumulação de capital (VIEIRA, 2009).

Lucas (1988) propõe um modelo de crescimento no mesmo exemplo de crescimento endógeno da economia que incorpora o capital humano. Seu modelo consiste em explicar a dinâmica de crescimento por meio da acumulação de capital humano, de maneira que as divergências nas taxas de crescimento entre os países são decorrentes da intensidade com que aumentam as dotações desse fator ao longo do tempo. Considera ainda que tende a ter mais habilidade e maior nível de produtividade os trabalhadores com mais estudos.

Cabe ressaltar que deixa de existir o crescimento econômico quando este permanece em estado estacionário pelas sociedades, isto é, o nível de investimento ou acúmulo de capita iguala-se à depreciação, portanto não ensejando a relação capital-trabalho constante e, fomentando baixos índices do PIB. Portanto, torna-se necessário o aumento de capital para superar a depreciação, o que nos orienta para novos investimentos. Acaso, sejam vislumbrados altos níveis de investimentos, a renda per capita aumenta. Isto é, segundo a teoria de Robert Solow:

$\mathrm{k}=\mathrm{sf}(\mathrm{k})-\delta \mathrm{k}$

Equação 2.1: Variação de capital

Dados da Equação: 
$\Delta \mathrm{k}=$ variação do capital

$\operatorname{sf}(\mathrm{k})=$ poupança em função do capital (ou seja, investimento)

$\delta \mathrm{k}=$ depreciação do capital

Para Vieira (2009), na posição de estado estacionário, steady state, o estoque de capital per capita fornece o produto que gera poupança e investimento de forma suficiente para que o estoque de capital, o consumo e o produto aumentem à mesma taxa que a população e a oferta de trabalho. Existindo a falta de progresso técnico, os valores per capita são constantes. Com isso, o crescimento em steady state, refere-se ao crescimento equilibrado de forma que não induza a alterações nos preços relativos, ou seja, a variação da razão capital/trabalho no modelo conduz a uma variação na produtividade marginal do capital e do trabalho que não proporciona alteração nos preços relativos da economia.

A hipótese de convergência da renda, que provém da suposição de retornos decrescentes para o capital, foi bastante explorada dos modelos de Solow-Swan. De acordo com tal hipótese, quanto menor o nível inicial do PIB real per capita, relativamente a posição de longo prazo - ou de estado estacionário - maior a taxa de crescimento. A convergência é condicional devido aos níveis de steady state do capital por trabalho e produto por trabalhador, de forma que dependem da taxa da poupança, da taxa de crescimento da população e da posição da função de produção, características que variam entre países (VIEIRA, 2009).

À medida que o investimento em máquinas e equipamentos eleva a renda per capita e acelera o crescimento dos países, a acumulação de capital físico assume papel importante. Considera-se ainda que, políticas que alteram a parcela da renda referente à poupança também auxiliam no processo de aceleração do crescimento e conduzem o sistema à trajetória de crescimento equilibrado. Uma vez que entre diferentes países as taxas de poupança e de crescimento da população variam, países diferentes alcançaram diferentes estados estacionários. Nessa perspectiva, quanto maior a taxa de poupança, mais rico é o país e, quanto maior a taxa de crescimento da população, mais pobre o país se tornará (VIEIRA, 2009).

Entretanto, não se pode considerar a população, por si só, como capital humano, o capital humano diz respeito à capacidade que um indivíduo tem em produzir com qualidade. No mesmo sentido, Pinto e Fredes (1974) afirmam que a melhoria do capital humano, focado nas necessidades humanas individuais ou coletivas é o que define a Teoria Econômica ou Economia Política, que 
por outro lado se encarrega de estudar problemas em termos abstrato e trata de determinar as leis que os regem. Já a Política econômica se encarrega de aplicar o conhecimento teórico proporcionado pela Economia Política a um estado determinado para se obter melhores frutos.

Vale ressaltar que os países em vias de desenvolvimento apresentam, além de uma baixa qualificação do capital humano, uma escassa dotação de capital físico, tornando mais difícil a aplicação das políticas adequadas que permitam aumentar o nível de qualificação dos habitantes. No que diz respeito ao capital humano, as modernas teorias do crescimento econômico destacam cada vez mais a importância de investimento no fator humano, objetivando melhorias em suas funções produtivas. Os investimentos em educação, formação profissional e em capacitação, assim como a porcentagem de universitários de um país, são fatores muito importantes no crescimento econômico, já que estão na origem de grande aumento na produtividade do trabalho. Neste contexto o desenvolvimento humano é fundamental para o crescimento econômico.

Hoffmann (2001) considera que o crescimento econômico é o tema central das ciências econômicas, que conta com o apoio da obra fundamental de Adam Smith para explicar a causa das riquezas das nações, que é uma das preocupações da humanidade nos dias atuais, visto que descreve um fenômeno que traduz o aumento da riqueza através da soma de todos os produtos e serviços finais, produzida por uma determinada região ou país, em um período de tempo, onde se destaca o PIB.

\subsubsection{Indicadores de crescimento econômico PIB}

O Produto Interno Bruto (PIB), no Brasil, medido pelo Instituto Brasileiro de Geografia e Estatística (IBGE) é um dos principais indicadores do país que serve para medir o crescimento econômico. Ele, o PIB, sintetiza a soma de todas as riquezas produzidas no país no período de um ano. Sua divulgação é feita a cada trimestre e inicia no primeiro trimestre depois do fechamento do ano, mas os dados definitivos só saem dois anos depois, quando são incorporados dados mais completos sobre a renda.

No mundo, a aplicação do método para cálculo do PIB iniciou-se em 1948 sob responsabilidade do Fundo Monetário Internacional (FMI). No Brasil, teve início no mesmo ano a cargo da Fundação Getúlio Vargas (FGV) até 1990. A partir de então, o cálculo ficou aos cuidados do IBGE que 
reestruturou a metodologia de cálculo do PIB fazendo com que seus resultados fossem integrados ao sistema de contas nacionais.

No entendimento de boa parte dos economistas, o PIB é significativo quando há harmonia entre os elementos que o compõe e o social: se há investimentos, empresas são abertas e mantidas, empregos são gerados e aumentam a renda e o consumo das famílias. Fatores que revelam a interrelação entre o PIB e o IDH.

O cálculo do PIB é feito pela oferta e pela demanda e, ao final, ambos devem fechar o mesmo valor. Nele, entra apenas o que se produziu no intervalo medido, o legado dos anos anteriores não entra no cálculo.

O IBGE usa os seguintes elementos para calcular o PIB:

- Valor de todos os produtos e serviços produzidos num país, calculado pela soma dos valores acrescentados por cada empresa, incluindo as empresas estrangeiras localizadas em território nacional, na agropecuária e no setor de serviços;

- Somatória de todos os rendimentos gerados num país, incluindo todos os valores pagos aos detentores dos fatores de produção (salários, rendas, juros e lucros).

- Apuração de todas as despesas efetuadas pelos agentes econômicos e dirigidas à produção nacional, que de fato são as despesas de consumo efetuadas pelas famílias, as despesas públicas efetuadas pelo governo, as despesas de investimentos feitas pelas empresas como compra de equipamentos e a balança comercial, com as exportações para o exterior. As importações têm uma representação negativa como sendo o dinheiro saindo do país.

Quando o resultado dos cálculos do PIB fecha negativo em dois trimestres consecutivos, a economia entra em estado de recessão técnica.

Equação 2.2: Estrutura de cálculo do PIB

PIB $=$ Consumo Privado + Renda + Total de Investimento realizado no período + Gastos do Governo + Balança Comercial (Saldo das Exportações-Importações).

Demonstrar o desempenho do PIB depende da consideração da performance de três setores na economia: Agropecuária, Indústria e Serviços. Expressa-se através do PIB, como anda o 
crescimento econômico de um dado setor. Para tanto, os bens e serviços finais são considerados na sua contagem. Os serviços, referem-se ao item consumo, influencia diretamente na variação do PIB. Dessa forma o aumento de serviços implica no crescimento do PIB em dado ano de contabilização.

Deve-se ainda entender que os serviços, enquanto expressividade do consumo, apoiam-se em dois elementos essenciais para o cálculo do PIB, ou seja, a renda das pessoas e a taxa de juros. Destacase que esta renda é a real, qual seja, descontada a inflação.

Especificamente a indústria, insere-se no rol dos investimentos privados, pois, dependendo da taxa de juros e o quanto a atividade econômica esteja aquecida, tem-se um nível de investimentos consideráveis, ou melhor, vislumbra-se a expansão do capital. Contudo, é o consumo da população quem define o PIB, ou seja, se o consumo é maior o PIB cresce. Além do consumo das famílias o a balança comercial também interfere no comportamento do PIB, quanto menor sejam as exportações, menor é a entrada de divisas e, consequentemente, ocorre a redução no PIB.

A conta de investimento do PIB é a Formação Bruta de Capital Fixo (FBCF), o qual serve para medir o quanto as empresas aumentaram os bens de capital - aqueles que servem para produzir outros bens como máquinas, equipamentos e construção civil que é outra variante deste indicador que deve ser considerada.

Cabe ressaltar que, conforme análise feita a respeito do crescimento do PIB, este não depende apenas das políticas internas de governo, do consumo das famílias ou do que é produzido no país mas também do comportamento financeiro internacional. Dependendo da política interna, os impactos negativos provenientes do meio internacional podem ser minimizados.

\subsection{DESENVOLVIMENTO ECONÔMICO}

O conceito de desenvolvimento econômico compreende um número expressivo de determinados aspectos, a partir de um grande número de indicadores socioeconômicos, entre os quais se destacam os seguintes: escolaridade da população, nível de produção e de rendimento por habitante, em longo prazo a taxa de desemprego, taxa de crescimento populacional, taxa de poupança por habitante, distribuição da renda e tecnologia e equipamentos.

Os desequilíbrios dos indicadores acima apresentados, ora em níveis elevados ora em baixos níveis, 
relatam a situação de países em vias de desenvolvimento. Não obstante, ainda que estes fatores sejam preocupantes por si mesmos, o fato mais alarmante em questão de desenvolvimento econômico é que as diferenças entre países desenvolvidos e os em vias de desenvolvimento aumentaram consideravelmente a partir das últimas duas décadas do século XX.

\subsubsection{Breve histórico da teoria do desenvolvimento econômico}

O desenvolvimento econômico nasce na história da humanidade, a partir do momento que o mundo inicia o processo de industrialização, onde foi possível, com recursos da indústria, melhorar as condições de vida das pessoas. Em virtude desse fato, surge uma sociedade que começa a se desenvolver econômica e socialmente. Já no Brasil, o processo de desenvolvimento econômico acentua-se quando a produção industrial passa a substituir a economia de caráter agroexportador no século XX. Vale lembrar aqui, que o responsável mais importante desse processo de desenvolvimento econômico foi o presidente Getúlio Vargas na década de 30 do século XX. Segundo Josef Barat (1991):

[...] os grandes investimentos feitos nos anos vinte permitiram que, até 1935-1936, instalada. A política anticíclica adotada pelo governo federal serviu para, de início, manter e, posteriormente, incrementar a rede interna, estimulando a industrialização pelo crescimento do mercado. (BARAT, 1991).

Desta forma, um ponto significativo nesta discussão sobre a industrialização no Brasil é que havia algumas limitações, sendo uma delas, a mais importante, a dependência externa da economia brasileira, redefinida, mas não eliminada após a descolonização. É salutar mencionar que o desenvolvimento faz referência a resultados do crescimento e estes são divididos na sociedade: erradicação da pobreza, melhoria dos salários e formas diferentes de renda. E também ao aperfeiçoamento das condições de trabalho, ao aumento da produtividade do trabalho e a participação nos resultados e ganhos dele decorrentes, melhoria das condições habitacionais, melhoria na alimentação, ao maior acesso à saúde, educação, infraestrutura de transporte e segurança.

Neste sentido, são essas políticas do desenvolvimento econômico, da disponibilidade de subsídios públicos para a produção e a infraestrutura nas cidades, bem como a expansão acelerada das infraestruturas de transportes, que beneficiam a população e a produção de manufaturas do mercado interno do país. 
Ainda, o desenvolvimento econômico no Brasil não pode ser mensurado de forma dissociada da história dos transportes, bastar ver a relação que este guarda com os índices econômicos. Dessa forma, passa-se à continuidade da análise multidimensional que é própria entre a história dos transportes e o desenvolvimento econômico, ressaltando que o desenvolvimento dos transportes ocorreu paralelo ao desenvolvimento econômico, pois os transportes promoveram o deslocamento de pessoas e mercadorias com vistas à produção e geração de emprego, renda e, consequentemente, acúmulo de capital.

\subsubsection{Desenvolvimento econômico: princípios gerativos}

O Índice de Desenvolvimento Humano (IDH), medido pelo Programa das Nações Unidas para o Desenvolvimento (PNUD), considera quatro os mais elementares conjuntos dos itens que as pessoas podem ser ou fazer: ter uma vida longa e saudável, ser instruído, ter acesso aos recursos necessários a um nível de vida digno e ser capaz de participar da vida da comunidade. Esses itens são sintetizados, pelas dimensões Longevidade, Escolaridade e Renda, para que se possa ter dados consideráveis - estatísticos e exequíveis na maioria dos países do mundo.

Pelas razões apresentadas, é relevante informar que diversos estados brasileiros já estejam adotando índices municipais mais amplos que o Desenvolvimento Humano Municipal (IDHM), como exemplo: Índice Paulista de Responsabilidade Social (IPRS), elaborado pela Fundação Seade em 1999-2000, por requerimento da Assembleia Legislativa paulistana.

Existe, entretanto, outro tipo de dificuldade que carece de ser discutida para que uma inquietante dúvida seja sanada. Trata-se, certamente, da aceitação cada vez mais generalizada de que não é suficiente o desenvolvimento; que não há mais nada o que acrescentar, mas que é fundamental que ele seja "sustentável" ". Alvo a ser perseguido. Neste sentido, tal ideia já não pode ser considerada nova, uma vez que se tornou conhecida a mais de 25 anos, embora tenha começado a ser colocada em documentos internacionais, bem antes, a partir de 1980, com a divulgação do relatório final da comissão mundial sobre o meio ambiente, gerida por "Gro Harlem Brundtland”. Esta comissão foi criada pela ONU e teve como objetivo reexaminar as questões pertinentes e críticas ao meio ambiente, propondo orientações e novas políticas, considerando os problemas existentes. Tal

\footnotetext{
2 A Primeira Ministra da Noruega Gro Harlem Brundtland, desenvolveu o conceito de sustentabilidade, hoje mundialmente aceito. Define o desenvolvimento sustentável como sendo "aquele que atende as necessidades do presente sem comprometer as possibilidades das gerações futuras atenderem suas próprias necessidades".
} 
proposta integra ao desenvolvimento econômico (BADER, 2008)

É fundamental que as questões relacionadas ao meio ambiente sejam tratadas com maior rigor e acrescentadas em todos os indicadores, tanto nos relacionados ao crescimento econômico, quanto nos relacionados ao desenvolvimento econômico, forçando, dessa forma, políticas que não comprometam o futuro, pois é do meio ambiente que provém todos os recursos necessários à vida e a economia de uma nação.

Os principais aspectos do desenvolvimento econômico estão diretamente relacionados ao desenvolvimento humano, ainda mais quando este atua exclusivamente no bem-estar do indivíduo, tal como emprego, cultura, lazer e condições que viabilizem sua inserção na sociedade, a partir de uma projeção econômica mínima para assegurar as necessidades básicas.

São vários os segmentos e temas que englobam os aspectos sociais que dizem respeito ao bemestar do indivíduo e qualidade de vida, uma vez que o objeto deste trabalho não é exclusivamente qualidade de vida/bem-estar do indivíduo, aqui serão abordados apenas os que são de maior relevância para o desenvolvimento da pesquisa.

Conceito criado pelo economista John Kenneth Galbraith, qualidade de vida, tem seus indicadores quantificados pela Organização Mundial de Saúde (OMS), é usado para medir as condições de vida do ser humano. Esse método envolve saúde, bem físico, mental, psicológico emocional, relacionamentos sociais, como família e amigos e também outras circunstâncias da vida (VEIGA, 2014).

Para a Organização das Nações Unidas (ONU), qualidade de vida é definida como o acesso a serviços urbanos de qualidade. A Constituição Brasileira de 1988 segue, basicamente, as definições da ONU e estabelece ainda que a sustentabilidade das cidades está vinculada à garantia de direitos da população a serviços urbano de qualidade, à moradia, trabalho e lazer, ou seja, a todas as condições que contribuem positivamente para o que se denomina como qualidade de vida nas cidades. Quanto maior o acesso a bens e serviços como educação, saúde e saneamento básico, itens que compõe o IDH, maior a possibilidade de se criar um ambiente favorável econômico e social (RIBEIRO ET AL, 2013). 


\subsection{3. Índices de Desenvolvimento Humano (IDH)}

Um grupo de pessoas do qual constavam os economistas Mahbud u-Haq e Amartya Sen, preocupado com questões relacionadas ao desenvolvimento, lançou o primeiro Relatório do Desenvolvimento Humano (RDH) em 1990, que deu origem ao IDH. O referenciado grupo, insatisfeito com a metodologia usada para medir o nível de desenvolvimento que se pautava apenas em dados quantitativos dos níveis de crescimento, propôs a ampliação de alternativas que rivalizasse com o PIB per capita e colocasse as pessoas como a verdadeira riqueza das nações (PNUD, 2014).

O primeiro RDH lança o IDH para além da dimensão da riqueza dos estados, representada no PIB per capita; inclui também duas outras grandezas com idêntica ponderação, a expectativa de vida e a alfabetização (DAMÁSIO, 2014). Este método padronizado, usado para avaliar o bem-estar de uma população num determinado país, foi desenvolvido em 1990 e vem sendo usado desde 1993 pelo Programa das Nações Unidas para o Desenvolvimento (PNUD) em seu relatório anual. Por meio das variações de índice entre 0 (pior) e 1 (melhor) e a combinação desse índice em um indicador síntese, demonstra-se que, quanto mais próximo de 1 estiver, maior o desenvolvimento humano $^{3}$ do país ou região.

Os níveis do desenvolvimento humano definidos pelo PNUD no intervalo de 0 a 1 são:

- Países menos desenvolvidos:

- Desenvolvimento humano baixo:

- Desenvolvimento humano médio:

- Desenvolvimento humano alto:

- Desenvolvimento humano muito alto:
0 a 386

0,387 a 0,393

0,394 a 0,592

0,593 a 0,717

0,718 a 0,878

Vale frisar que o valor do nível do Índice de Desenvolvimento Humano poderá sofrer variações, para mais ou para menos, na inserção ou retirada de item dos dados que compõem o indicador, na mudança da estrutura do cálculo, como ocorreu, quando a média das três dimensões Longevidade,

\footnotetext{
${ }^{3}$ Além de medir a variação dos níveis de desenvolvimento humano dos países, também é capaz de avaliar as ações promovidas pelos governos e pela sociedade no intuito de diminuir as desigualdades sociais.
} 
Educação e Renda deixou de ser pela média aritmética e passou a ser calculada pela média geométrica, fazendo com que o valor se apresente menor.

\subsubsection{Base de cálculo do IDH e suas respectivas dimensões}

Quando completou 20 anos em 2010 novas metodologias foram incorporadas para o cálculo do IDH; entretanto, ainda mantém as três dimensões, saúde, educação e renda, sendo que a dimensão saúde eventualmente é substituída por longevidade com a consideração de que, para ter vida longa, necessariamente precisa ter saúde.

Para mensurar o IDH é necessário criar sub-índices para cada uma das três dimensões, depois aglutinar num único índice, que é o próprio IDH, que atinge valores compreendidos no intervalo entre 0 e 1.

Equação 2.3: Índice de dimensão Longevidade, Educação e Renda

Índice de dimensão $=\frac{\text { valor observado-valor mínimo }}{\text { valor mínimo-valor máximo }}$

Representando este índice a média geométrica dos três índices de dimensão mencionados, há que ajustar cada um deles, transformando os indicadores das dimensões em sub-índices cujos valores estejam contidos estritamente no intervalo de 0 a 1 . A fórmula utilizada para o efeito é a seguinte:

Equação 2.4: Média geométrica das três dimensões do IDH, Saúde, Educação e Renda $I D H=\sqrt[3]{I D H_{\text {Saúde }} X I D H_{\text {Educação }} X I D H_{\text {Renda }}}$

Com base nos dados dos levantamentos do IDH de 2010, Damásio (2013) considera que a inovação ocorrida no mesmo em usar a média geométrica em substituição à aritmética foi vantajosa porque a média geométrica ao penalizar mais os valores extremos, implica na não substituição adequada entre as três dimensões. Assim, produzindo, por si só, valores mais baixos de IDH, um estado que apresente uma das dimensões significativamente menor que as restantes, será penalizado e, desta forma, a sua pontuação deteriorar-se-á.

Inerente às dimensões do IDH: educação onde verifica-se anos médios de estudos, longevidade com vistas à expectativa de vida da população e PIB per capita que é a renda média por pessoa. O indicador longevidade, que é a esperança média de vida ao nascer, mensura as condições de saúde e salubridade de determinada região, além de demonstrar o número medido de anos que uma pessoa nascida em determinado local deve viver. 
A variável educação compreende a taxa de escolaridade da população adulta e a taxa do fluxo escolar da população jovem. Quanto à mensuração da renda per capita, temos como critério utilizado, a soma da renda de todos os residentes, dividida pelo número de pessoas que moram no país, região ou município - inclusive crianças - e pessoas sem registro de renda.

Apesar do indicador IDH ter melhorado com a mudança na estrutura de cálculo da média geométrica para aritmética, ainda não abrange questões relacionadas ao meio ambiente e a mudanças climáticas, requisitos esses importantes à vida e que não devem ser desprezados. Nem mesmo o IDH municipal contempla itens mais amplos como o proposto, pois segue o padrão do IDH global.

\subsection{5. Índice de desenvolvimento humano municipal - IDHM}

Com base no senso populacional IBGE (2000), no Brasil foi criado o Índice de Desenvolvimento Humano Municipal (IDHM), que é o IDH dos municípios. Ele é a quarta parte do Relatório do Desenvolvimento Humano Brasileiro. Esse esforço foi sintetizado no formato do Atlas do Desenvolvimento Humano Municipal, com muitos dados e edições específicas. Com esses dados disponíveis, tornou-se possível abrir um conjunto de novas possibilidades de uso de informações.

Ao mesmo tempo que se criou uma nova demanda de cálculo a partir dos dados tradicionais, estes, ao serem dependentes do censo demográfico, limitavam sua atualização a períodos de dez anos. Essa nova demanda de dados do IDHM surge, então, da necessidade de se poder contar com dados do IDH que sirvam para o monitoramento de políticas públicas locais e regionais e que apresentem estudos acadêmicos que contemplem perspectivas de curto prazo mais relacionados à configuração de políticas econômicas e sociais (PNUD, 2010).

Com intuito de melhor expressar as condições sociais de unidades geográficas como os municípios, o PNUD, conjuntamente com o Instituto de Pesquisa Econômica Aplicada (IPEA) e a Fundação João Pinheiro assumiram a responsabilidade de adaptar os componentes utilizados nas dimensões do IDH Global Longevidade, Educação e Renda para calcular IDHM de todos os municípios brasileiros, a partir de dados do Censo Demográfico do IBGE, 2010.

Os cálculos do IDHM foram feitos com base na metodologia utilizada nos anos de 1991 e 2000, através da compatibilização das áreas municipais entre 1991, 2000 e 2010, levando em 
consideração as divisões administrativas ocorridas no período e fazendo comparabilidade temporal e espacial entre os municípios. O desafio já havia sido enfrentado nas edições do Atlas de 1998 e 2003 (PNUD, 2014). Todos os indicadores de suporte ficam reunidos no Atlas do Desenvolvimento Humano do Brasil 2013.

A taxa combinada de matrícula mais os indicadores PIB per capita foram substituídos, respectivamente, pela renda familiar per capita média do município e pelo número médio de anos de estudo da população adulta (25 anos ou mais). A taxa de alfabetização de adultos utilizada pelo IDH foi substituída no IDHM pela taxa de analfabetismo na população de 15 anos e mais. O quarto e último indicador utilizado pela metodologia do IDHM, a esperança de vida ao nascer, tem o mesmo conceito utilizado pelo IDH.

Para melhor compreensão da posição dos níveis do IDHM, observam-se: muito baixo, baixo, médio, alto e muito alto, Figura 2.1, apresenta a faixa de desenvolvimento para cada nível.

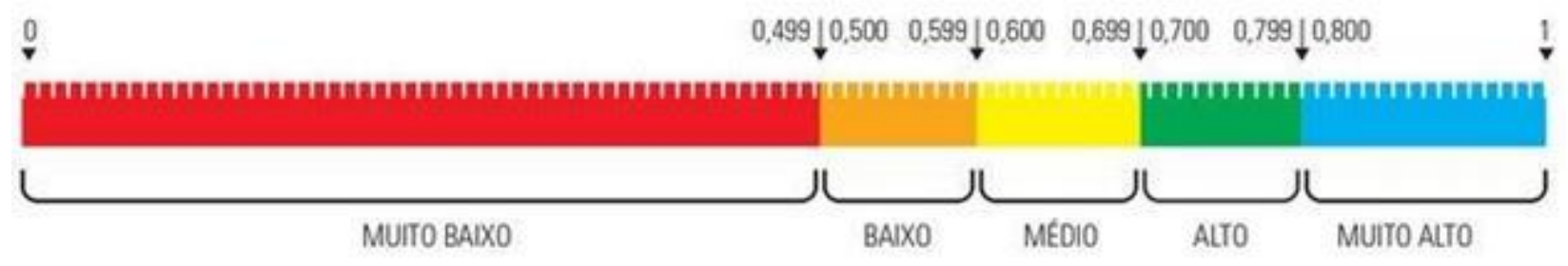

Figura 2.1: Faixas de Desenvolvimento Humano Municipal

Fonte: PNUD (2014)

Qualquer alteração de valor em qualquer uma das três dimensões Longevidade, Educação e Renda interfere diretamente no resultado do ID. A condição ideal é que cresçam com foco a se aproximar de" um". Nota-se que quanto maior o número de pessoas na faixa de 0 a 0,499 que é um nível muito baixo e baixo, menor nas faixas subsequentes médio, alto e muito alto, maior é a desigualdade das condições de vida das pessoas.

\subsubsection{Base de cálculo do IDH municipal e seus respectivos índices}

$\mathrm{O}$ cálculo do IDHM foi adaptado à metodologia do IDH Global, ajustado à realidade brasileira, com indicadores adequados para também avaliar as condições dos núcleos sociais menores, disponíveis no censo demográfico.

Usa-se, no entanto, a média geométrica para calcular os três pilares do IDHM, similar ao IDH: 
- Saúde ou Longevidade (Vida longa e saudável/Expectativa de vida)

- Educação $\sqrt[3]{(\text { Escolaridade da população Adulta x Fluxo da População Jovem) }}$

- Renda (Renda per capita)

Equação 2.5: Cálculo geométrico das dimensões do IDHM Saúde, Educação e Renda $I D H M=\sqrt[3]{I D H_{\text {Saúde }} X I D H_{\text {Educação }} X I D H_{\text {Renda }}}$

A alteração da base de cálculo de média aritmética para geométrica do IDHM beneficia mais as cidades que apresentam as dimensões Saúde, Educação e Renda menores do que as cidades que possuem essas mesmas dimensões mais altas. Com o resultado, requererá dos gestores maior atenção e esforços para a redução das desigualdades existentes entre cidades com indicadores menores.

\subsubsection{Desenvolvimento Econômico Regional}

O desenvolvimento econômico regional pode ser considerado como uma manifestação histórica ligada aos países capitalistas e, obviamente, possui forte relação com a produção e a renda por habitante. É mister dizer que, em relação ao aspecto histórico, em meados do século XX, muitos cientistas, não se sentindo confortáveis com a situação da época, iniciaram seus estudos no que tange a problemas que afetavam as sociedades modernas: o desenvolvimento desigual entre regiões de um país. Como exemplo, o Brasil que cresceu socioeconomicamente com muitas diferenças. É sabido que o país passou por uma forte crise no início da década de sessenta. Houve uma estagnação drástica considerável em vários setores. Neste sentido Lessa et al. afirmam que:

Entre 1962 e 1967 a economia brasileira atravessou sua pior fase do pós-guerra no que se refere ao crescimento, enquanto se promovia modificações profundas tanto no arcabouço da política econômica (financiamento público, privado e externo, comércio exterior e capital estrangeiro) como nos padrões de distribuição funcional e pessoal da renda (...).

Neste recorte sincrônico, observa-se a oscilação de evolução da economia. Assim, "O lento crescimento não foi uniforme ao longo destes anos; observa-se momentos mais desfavoráveis em meados de 1965 e princípios de 1967” (LESSA ET AL, 1982).

O desenvolvimento econômico deve ser sustentável de forma a mesclar mudanças econômicas, sociais e culturais de uma população que a tornam preparada a crescer, cumulativamente e de forma 
gradativa. No desenvolvimento regional existe o entendimento da inclinação econômica, das especializações produtivas estabilizadas e de novas oportunidades econômicas da região que se deseja desenvolver. Esta combinação de ideias é essencial para a definição de ações que visam robustecer o desenvolvimento e a competitividade regional, os quais podem ser elencados como: recursos humanos, tecnologia e inovação, infraestrutura, gestão, ambiente de negócios e posicionamento de mercado.

Como as sociedades capitalistas desenvolveram primeiramente na Europa e depois nos Estados Unidos, de forma a serem incapazes de se conformarem com seus estágios de desenvolvimento, a "ciência regional" ou ainda "geografia organizacional do espaço" destas localidades, tornou-se referência para os demais países; a longo prazo dificilmente regride, pois a acumulação de capital em uma economia com dinâmica de crescimento passa a ser uma forma de sobrevivência. E claro, para que isto ocorra, a infraestrutura possui papel essencial nesta construção.

No entanto, quando uma sociedade é capaz de se conformar com sua situação econômica, não há desenvolvimento. É necessário que haja iniciativa do Estado para que desperte o espírito da política do crescimento econômico e social.

Para Oliveira Jr. (1996), transformação da política de transportes em instrumento de desenvolvimento regional precisa incorporar as dimensões de integração intra e intersetorial, para que o transporte, como condição necessária, mas não suficiente do processo de desenvolvimento, possa ser efetivo. Oliveira Jr. cita como exemplo, a política de saneamento básico e de abastecimento de água como sendo fundamental para a redução dos índices de mortalidade infantil. Com isso considera que políticas públicas precisam ser incluídas no planejamento.

O desenvolvimento econômico é visto como uma extraordinária ação caracterizada pela melhoria das condições de vida do ser humano, tanto no aspecto histórico quanto num período observado. Outra característica do desenvolvimento econômico é a realização do progresso bem como a conservação da produtividade ou da renda por pessoa em que se deve acompanhar, por um procedimento das dinâmicas locais, cuja avaliação sob a perspectiva histórica, é estratégica para a compreensão dos fatores a ele relacionados. A cultura regional pode ser examinada, especialmente, por um ponto de discussão intrínseco: aspectos institucionais e sociais, e os fatores que podem ser considerados fundamentais para a melhoria da qualidade de vida ofertada em uma determinada 
região, já que o caminho trilhado pode ou não ter impacto similar a uma outra.

De maneira mais técnica, estes caminhos são circuitos da região com uma elaboração criteriosa no que se refere a um processo de acumulação de bens e da difusão das novas tecnologias, as quais provocam mudanças importantes em vários aspectos. Primeiramente, por ter gerado maior flexibilidade nos processos produtivos, uma vez que isto altera os modos de produção e organização das empresas, desestruturando a administração e elevando à análise dos resultados, bem como dos efeitos dessas novas tecnologias sobre as economias em desenvolvimento. Em outras palavras, é mister pensar na expansão interna de tal economia e nas mudanças estruturais que aumenta o segmento produtivo essencialmente no setor terciário, explanando significativamente a participação deste na economia.

Em relação à convergência transporte desenvolvimento econômico, é possível dizer que o primeiro é instigador do segundo e que, por esta razão, desempenha um papel fundamental na economia regional, o qual é traduzido em termos de produção. E obviamente, interfere na distribuição de renda entre os indivíduos de um grupo social. O desenvolvimento econômico no Brasil não pode ser mensurado de forma dissociada da história dos transportes, haja vista a relação que este guarda com aquele, tendo em vista o acúmulo de bens de capital e o desenvolvimento da sociedade. Dessa forma, passamos à continuidade da análise multidimensional que é própria entre a história dos transportes, o desenvolvimento e crescimento econômico. 


\section{PLANOS DE TRANSPORTES NO BRASIL}

Muitos foram os planos de investimentos para expansão territorial e crescimento das regiões brasileiras. Para se chegar aos planos nacionais relacionados à malha rodoviária existente no país propriamente dita, é necessário apresentar histórico acerca do desenvolvimento do transporte brasileiro.

Na Primeira República, 1889-1930, verificou-se o auge da malha ferroviária brasileira. Sua expansão teve início na década de 1850 , tendo o governo brasileiro tanto o objetivo de proporcionar a entrada do capital estrangeiro no país, principalmente inglês, quanto o de dar suporte à exportação de produtos. Segundo Anísio Brasileiro (2001), a construção das ferrovias teve seu ápice nas décadas dos anos 1870 e 1880 com 5.129 km construídos, entre 1876 e 1885 e 6.546 km construídos, entre 1886 e 1896.

Com a crescente expansão da produção cafeeira e da industrialização iniciada no final do século XIX, uma das providências adotadas para estruturação do setor de transportes brasileiro foi a criação do Ministério de Indústria, Viação e Obras Públicas em 1891, transformado em 1909 no Ministério de Viação e Obras Públicas.

O mencionado Decreto $\mathrm{n}^{\circ} 862$, de 16 de outubro de 1890, que teve por objetivo incentivar as empresas ferroviárias, previa ligações entre o Estado de Goiás e Mato Grosso e concedia linhas de navegação a vapor sub-convencionadas no Baixo Tocantins, entre Belém e o início da via férrea de Alcobaça no Alto Tocantins. O referido decreto também concedeu privilégio de exploração por 60 anos e concedia juros de $6 \%$ ao ano sobre o capital empregado, durante trinta anos, além de prever a cessão de terras devolutas numa extensão de $20 \mathrm{~km}$ para cada lado das vias férreas e fluviais e também conceder isenção de direitos de importação sobre os materiais utilizados na construção e para o carvão de pedra usado no tráfego.

No entanto, mesmo com os incentivos mencionados, o projeto de expansão das ferrovias não teve sucesso, tendo o governo arcado com grandes prejuízos por causa dos abusos cometidos por parte dos concessionários no regime da garantia dos juros, que proporcionava lucros fáceis permitindo a eles, o descuido com a economia de custos e também com as indenizações pagas por conta das rescisões contratuais. A falta de projetos, a qual pode ser constatada por meio do tamanho diferenciado das bitolas das ferrovias, impedia a integração futura entre as estradas construídas, as 
linhas ferroviárias projetadas para o escoamento da produção do café e açúcar sem qualquer integração entre si e, a mudança da produção para outra região, fazendo com que as ferrovias perdessem sua finalidade (BRASILEIRO ET AL, 2001) também contribuíram para o fracasso dos planos de expansão das ferrovias.

Josef Barat (1978) acrescenta que:

A partir da II Grande Guerra iniciou-se o processo de deterioração contínua do sistema ferroviário. As estradas de ferro, que ainda funcionavam sob a forma de concessão e de propriedade privada, foram encampadas pelo setor público. A obsolência do equipamento e suas deficiências operacionais transferiram-se para o setor público.

Os prejuízos e desvantagens anteriormente demonstrados, ocorridos na utilização do sistema ferroviário brasileiro foram dando lugar à utilização do transporte rodoviário, tendo em vista as grandes vantagens operacionais por ele oferecidas, mesmo com o baixíssimo volume de tráfego movido à tração animal apresentado no início do século XX. A chegada dos primeiros veículos automotores no Brasil ocorrida nos anos de 1893 e seguintes, trouxe consigo a necessidade de implantação de rodovias onde esses veículos pudessem trafegar. Somente em 25 de outubro de 1910, por meio do Decreto n 8.324, foi que o Governo Federal decidiu incentivar a construção rodoviária no país. O referido decreto trazia subsídios pagos pelo Governo por quilômetro de rodovia construída dentro das especificações contidas no projeto por ele determinado com vista à padronização mínima de tecnologia rodoviária e previa ainda, a criação de serviços subvencionados de transporte rodoviário de passageiros e de transporte de cargas por automóveis.

O I Congresso Paulista de Estradas de Rodagem no ano de 1971, presidido pelo então prefeito da cidade de São Paulo, Washington Luís, destacou a necessidade de se construir estradas modernas para automóveis. Neste período, conforme assevera Ferreira Neto (1974), já circulavam pelo território brasileiro cerca de 5.000 automóveis e $90 \%$ desses rodavam entre Rio de Janeiro e São Paulo, sendo usados somente nos centros urbanos, em face da precariedade das estradas existentes, as quais serviam unicamente para o tráfego de carroças.

Outro fato marcante a ser destacado para o desenvolvimento rodoviário foi a chegada das empresas automobilísticas Ford (1919) e General Motors (1925) ao Brasil. Neto (1974) registra que:

Em 1919, a Ford Motor Company tinha autorização para funcionar no Brasil e foi 
instalada em São Paulo uma organização industrial para montagem do seu modelo $\mathrm{T}$, que viria dos Estados Unidos em peças, aproveitando a mão-de-obra nacional. Devido a essas circunstâncias, que lhe dava uma série de vantagens, o automóvel poderia ser vendido por um preço que o tornaria acessível à classe média nacional [...] Em 1925, coube a General Motors tomar a mesma iniciativa, embora o seu carro, mais luxuoso e potente que o modelo $\mathrm{T}$, fosse destinado a uma categoria mais elevada de usuários. Suas instalações começaram a operar com a capacidade de montar diariamente 25 carros.

\subsection{OS PLANOS RODOVIÁRIOS NO BRASIL}

Em 1926 Washington Luís assume a Presidência da República, tendo como lema "Governar é construir estradas", e traz a construção rodoviária da condição de plano à diretriz básica de política pública em âmbito federal. Segundo Brasileiro (2001), o Decreto no 5.141/1927, instituiu o Fundo Especial para Construção e Conservação de Estradas de Rodagem Federais, formado pelo imposto adicional sobre os combustíveis e veículos importados, a ser aplicado com exclusividade na construção e conservação das estradas de rodagem federais em todo o território nacional, e previa ainda, em seu artigo $5^{\circ}$, o repasse de verbas federais aos Estados para o apoio ao desenvolvimento de programas voltados para a expansão de suas respectivas malhas rodoviárias.

Motivados pelo então Presidente do Brasil, Washington Luís, que entendia haver a necessidade de se "construir estradas para todas as horas do dia e para todos os dias do ano" foram apresentados alguns planos de implantação das rodovias federais que serviram de base aos planos nacionais de viação posteriores, embora não tenham sido aprovados oficialmente (BRASIL, 2014). A seguir a descrição de cada Plano realizado:

- Plano Catramby (1926/1927) - primeiro conhecido do gênero que previa um plano geral para a base rodoviária brasileira e propunha a construção de rodovias superpostas aos traçados ferroviários. Foi apresentado no $4^{\circ}$ Congresso Nacional de Estradas de Rodagem na cidade do Rio de Janeiro, e era formado por dezessete estradas federais, ou troncos de penetração; e por doze estradas estaduais ou de união dos estados, adotando, resumidamente, princípios

predominantes dos planos ferroviários apresentados anteriormente, introduzindo a superposição de traçados.

- Plano Luiz Schnoor (1927) - previa a construção de rodovias irradiando da localização da futura capital federal no planalto central para as demais regiões do país e, em muito assemelhava-se ao que temos atualmente. O referido Plano sofreu inúmeras críticas em face 
das superposições de numerosos traçados rodoferroviários e pela falta de justificação geoeconômica de vários traçados.

- Plano da Comissão de Estradas de Rodagem Federal (1927) - propôs a construção da malha rodoviária passando pelo planalto central, mais focada no centro-sul e nordeste do Brasil. Assemelha-se ao Plano Schnoor, sendo, entretanto, mais realista. Importante salientar que nada de concreto em relação aos estudos elaborados pela referida Comissão de Estradas de Rodagem Federal foi encontrado, apesar das buscas realizadas.

Só a partir de 1930 foi que o governo federal passou a tratar a questão das rodovias brasileiras com maior profundidade. A primeira providência adotada pelo Ministro de Viação do Governo Vargas, José Américo de Almeida, foi a elaboração de um plano geral de viação que desse subsídio ao governo na tomada de decisões para investimento nos transportes nas áreas ferroviária, rodoviária e da navegação de cabotagem, surgindo daí, o Decreto no 24.497, de 29 de junho de 1934.

O Plano Geral de Viação Nacional (PGVN) de 1934, fixou a orientação de nove troncos com direção norte-sul, onze troncos que se dirigiam de leste para oeste e, também, dezoito ligações as quais estabeleciam comunicação entre eles ou ligavam a determinados pontos da fronteira, conforme demonstrado pela Figura 3.1. 


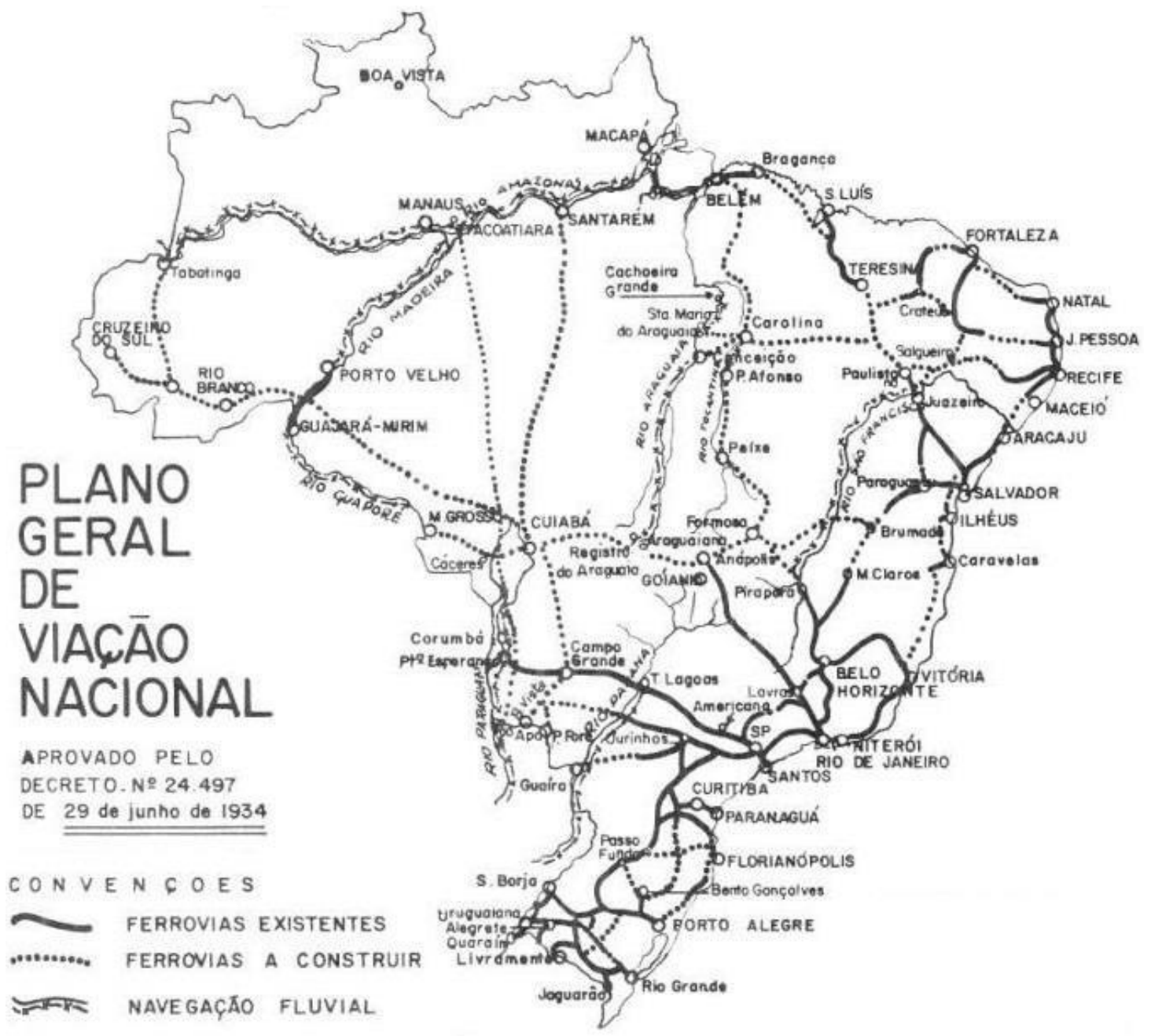

Figura 3.1: Plano Geral de Viação Nacional - Decreto no 24.497, de 19347, de 1934 Fonte: Planos de Viação Evolução - Histórica 1808 - 1973

Mesmo não tendo distinguido se os troncos e ligações terrestres seriam construídos por meio de rodovia ou ferrovia, uma das conclusões do parecer apresentado pela Comissão designada para a elaboração do PGVN/1934 foi que, somente a estrada de ferro seria a solução definitiva para o estabelecimento dos troncos previstos (Brasil, 1976).

O PGVN/1934 também previa, as chamadas vias mistas, dentre as quais destacou-se a TM-3, trecho inicialmente traçado da Rodovia Federal BR-153, objeto de estudo deste trabalho, e compreendia um percurso navegável do Rio Tocantins de Carolina/MA à Pedro Afonso. Neste período, a Lei $\mathrm{n}^{\circ}$ 467, de 31 de julho de 1937 criou o Departamento Nacional de Estradas de Rodagem - DNER, com a atribuição de organizar as estradas de rodagem nacionais que estavam sob sua direção e execução. 
Diante de suas atribuições, foi elaborado, no mesmo ano de sua criação o Plano Rodoviário do DNER/1937, demonstrado pela Figura 3.2.

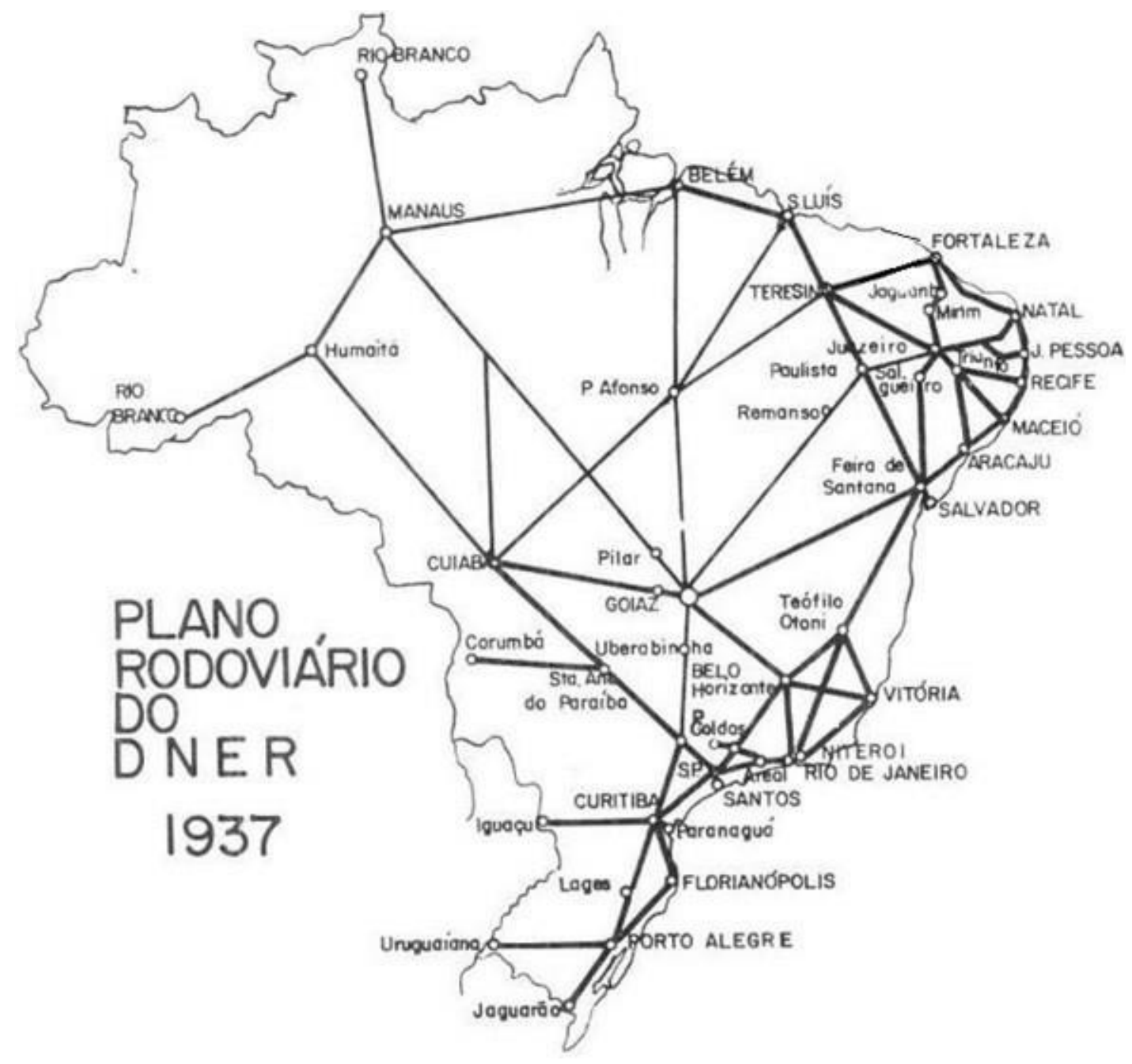

Figura 3.2: Plano Rodoviário do DNER 1937

Fonte: Planos de Viação Evolução - Histórica 1808 - 1973

No plano rodoviário do DNER (1937) previu-se a construção da atual BR-010, passando pelo lado esquerdo do Rio Tocantins, pelo município de Pedro Afonso, beneficiando a cidade de Itacajá, então pertencente ao referido município.

O primeiro Plano Rodoviário Nacional, instituído pelo Decreto nº 15.093, de 20 de março de 1944, previa a construção de vinte e sete linhas federais, sendo seis rodovias longitudinais, quinze transversais e seis radiais, num total de $35.574 \mathrm{~km}$, cada uma delas com a nomenclatura de "BR" acrescido de um número (BRASILEIRO, 2001). 
Dentre as rodovias longitudinais, destaca-se a Rodovia Transbrasiliana, BR-153, que fazia o trajeto de Belém/PA a Santana do Livramento/RS, com o seguinte percurso: Belém - Guamá - Imperatriz - Porto Franco - Carolina - Pedro Afonso - Tocantínia - Porto Nacional - Peixe - São José do Tocantins - Anápolis - Goiânia - (Ponte Afonso Pena, sobre o Rio Paranaíba) - Triângulo Mineiro (Ponte General Mendonça Lima, próxima à Cachoeira dos Marimbondos, no Rio Grande) - Rio Preto - Lins - Marília - Ourinhos - A. Bernardes - Porto União - Marcelino Ramos - Passo Fundo - Santa Maria - são Gabriel - Santana do Livramento. (BRASIL, 1976).

Cabe salientar que, estava prevista a passagem da Rodovia BR-153 pela cidade de Pedro Afonso/TO cidade a que o então Distrito de Itacajá pertencera. O texto do decreto ressalta ainda que a diretriz indicada no primeiro trecho que vai de Belém-PA a Peixe, na época, pertencente ao Estado de Goiás, com extensão aproximada de $1.622 \mathrm{~km}$, seria a mesma do prolongamento ferroviário de Pirapora a Belém, ou seja, os pontos principais seriam os seguintes: Belém Imperatriz - Porto Franco - Carolina - Pedro Afonso - Tocantínia - Porto Nacional - Peixe.

Para os referidos trajetos o PRN de 1944 adotou alguns critérios básicos:

- Evitar a superposição das rodovias com os troncos ferroviários principais;

- Aproveitar trechos de rodovias existentes ou em projeto, dos planos estaduais;

- Considerar apenas trechos rodoviários de caráter nacional;

- Estabelecer, no interior do país, as convenientes ligações da rede rodoviária nacional com a infraestrutura aérea. TRANSPORTES (2014)

Embora o Presidente Getúlio Vargas tenha reconhecido e dado apoio ao setor rodoviário pelo fato deste impulsionar o desenvolvimento da indústria brasileira, durante o período da guerra houve uma desaceleração no setor rodoviário em face das restrições estabelecidas para a compra de combustíveis líquidos, que impediam a utilização de equipamentos usados nos trabalhos de terraplanagem das estradas. (BRASILEIRO, 2001, APUD NETO, 1974).

No ano de 1945, houve mudanças significativas para o setor rodoviário brasileiro, que por influência de Maurício Joppert da Silva, Ministro da Viação do governo interino de José Linhares, estabeleceu várias ações que repercutiram nas ações de construção e reforma das rodovias da época. Com a edição do Decreto-lei no 8.463/45, conhecido como "Lei Joppert, o DNER foi transformado em autarquia e foi criado o Fundo Rodoviário Nacional (FRN), formado pelo imposto único destinado à construção e conservação das rodovias federais, estaduais e municipais, recurso que os 
estados passaram a receber através de seus órgãos em semelhança ao DNER, para a construção, conservação e melhoramento das estradas, o qual daria suporte ao DNER para implantação das rodovias no interior do Brasil.

Com a criação da Comissão de revisão e atualização do Plano Geral de Viação Nacional de 1934 (PBGVN/34), criada pelo Ministro Joppert, por meio da Portaria n ${ }^{\circ}$ 19, de 8 de janeiro de 1946, foi que as estradas passaram a ter um importante papel no desenvolvimento do país, com a utilização de todos os meios de transporte, quer seja rodoviário, ferroviário ou fluvial, na política de ocupação do território brasileiro, em contraposição ao referido Plano Geral de 1934 que tinha a preocupação de implantar somente um único meio de transporte nas várias regiões do país.

Os estudos finais da comissão responsável pela revisão do PGVN/1934, foram encaminhados pelo Poder Executivo acompanhados pela mensagem n 242 do Presidente da República para a aprovação do Congresso Nacional em 9 de junho de 1948, transformando-se no Plano Nacional de Viação de 1951. O referido plano () nunca foi aprovado formalmente pelo Congresso Nacional, conforme TRANSPORTES (2014). 


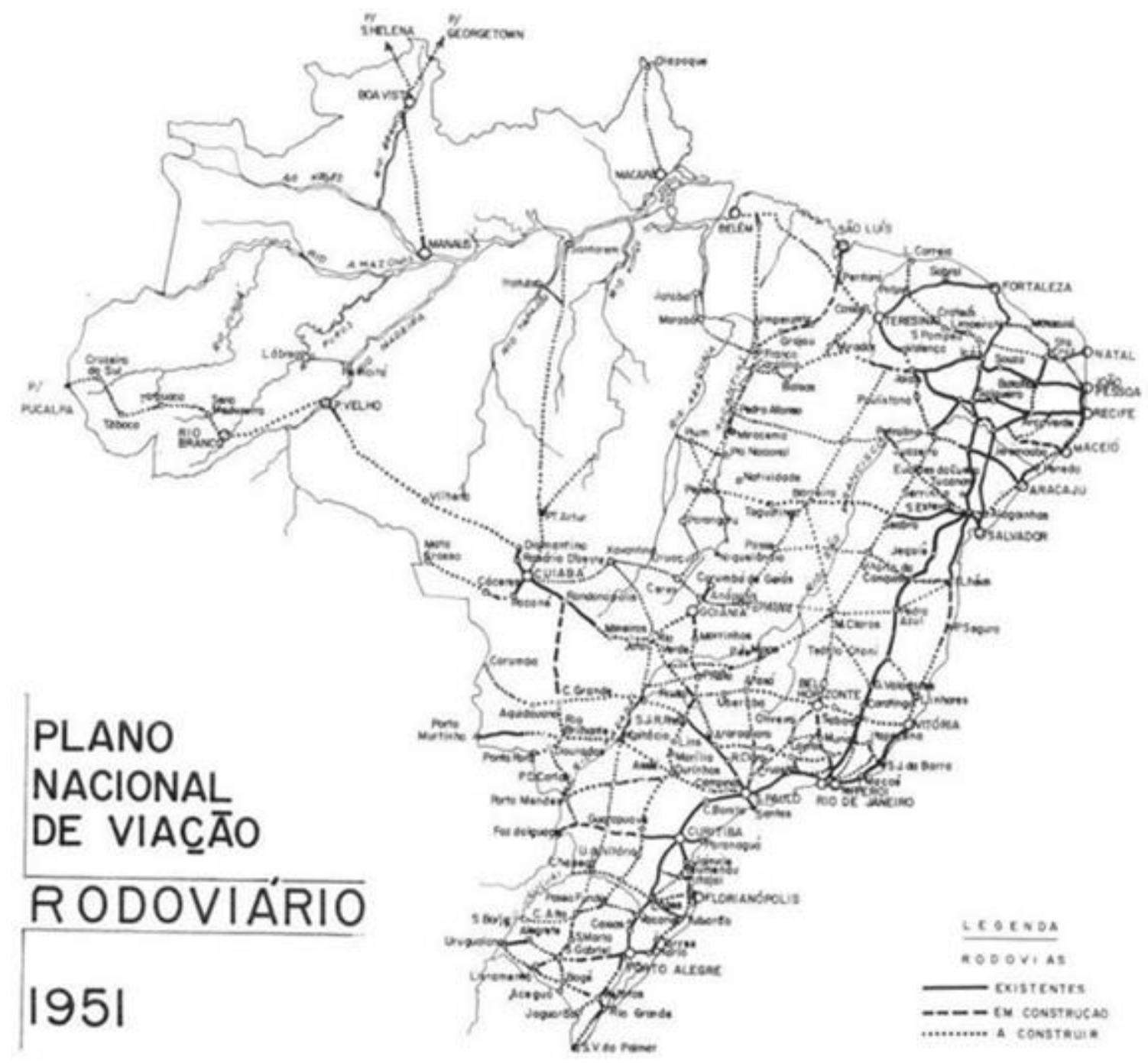

Figura 3.3: Plano Nacional de Viação Rodoviário Fonte: Planos de Viação Evolução - Histórica 1808 - 1973 (Brasil, 1974)

O lançamento do Plano SALTE em 1948, no governo de Eurico Gaspar Dutra, que vai do ano de 1946 a 1950, “(...) era, na verdade um conjunto de programas econômicos e sociais nos campos da saúde (S), alimentação (AL), transportes (T) e energia (E)" Brasil e Barbosa (1976). O referido plano previa recursos físicos, materiais e financeiros para todos os meios de transportes. A parte relativa aos transportes baseou-se nos planos anteriores, quais sejam, Plano Nacional de Viação PNV de 1934 e Plano Rodoviário de 1944. Nesse período, ocorreu também a construção da estrada Rio-São Paulo, conhecida como Via Dutra. 
Com a posse do Presidente Juscelino Kubistchek da República em 1956 e em face da necessidade de implantação do Programa de Metas que previa "50 anos de progresso em 5 anos de realizações" o Congresso Nacional aprovou em caráter provisório, os programas de obras rodoviárias e ferroviárias previstas no Anexo da Lei 2.975, de 27 de novembro de 1956, cuja ementa trazia a alteração da legislação relativa ao imposto único sobre combustíveis líquidos e gasosos. O Plano de Metas do Presidente Juscelino consistia em trinta metas abrangendo investimentos para o setor ferroviário, rodoviário, portuário e marinha mercante. Neste período, dois grandes fatores impulsionaram o desenvolvimento do setor rodoviário: a chegada da indústria automobilística e a construção de Brasília, a qual não estava prevista inicialmente e ficou conhecida como "metasíntese".

A localização da Capital Federal no Planalto Central trouxe a necessidade de um plano rodoviário nacional que a interligasse com todas as demais regiões do país, promovendo inclusive a interiorização, prevista desde os tempos do império português. Para isso, grandes eixos rodoviários foram implantados a saber: Belém-Brasília, Brasília-Fortaleza, Brasília-Belo Horizonte, BrasíliaAnápolis e Brasília-Acre Brasileiro (2001).

Nesse período destacou-se também a construção da rodovia Transbrasiliana, BR-153, cujo projeto de ligação da Região Norte com a Região Sul pelo centro do país, era previsto desde o final do século XX, quando o Engenheiro Jales Machado, Secretário de Obras da Província de Goiás, ao viajar de Anápolis, passando pelo Rio Tocantins e Araguaia, teve a ideia de implantação de uma ligação rodo-ferro-fluvial que iria de Anápolis a Belém (Brasileiro, 2001). Essa ligação estava prevista anteriormente na forma de ferrovia no Plano Schnoor e o Plano Geral de Viação Nacional de 1934 viria confirmar a construção. O Plano Rodoviário Nacional de 1944 incluiu como um de seus principais eixos, uma rodovia que se chamaria Transbrasiliana, cortando o país de sul a norte, com início em Santana do Livramento até Belém/PA (BRASILEIRO,2001).

A inauguração oficial da Rodovia BR-153 ocorreu somente em 02 de fevereiro de 1960, com o trânsito de automóveis produzidos no país, os quais compunham a chamada Caravana da Integração Nacional, saindo das regiões dos quatro pontos cardeais, no dia 23 de janeiro de 1960, e chegada a Brasília prevista para o dia 31 de janeiro de 1960. Comemorando a chegada da Caravana de Integração Nacional a Brasília, Juscelino, e um dos trechos do discurso da comemoração. Aqui 
destaca-se a importância da Rodovia Transbrasiliana, BR-153, para o país, conforme abaixo transcrito:

- Já temos uma transbrasiliana, já é possível viajar por terra de Belém a Porto Alegre - o que equiivale a ir de Lisboa a Moscou, ou de Nova York à Califórnia. Digo isto, meus senhores, mais com uma sensação de alívio do que de alegria. É que confesso que demoramos demais a chegar a este resultado (KUBITSHECK, 1960).

O Plano Nacional de Viação de 1934 vigorou no Brasil até o ano de 1964. Somente com a Lei 2975/5, promulgada no Governo de Juscelino Kubitscheck os planos rodoviário e ferroviário foram alterados. Depois de trinta anos do início da revisão do PGN/1934, a publicação da Lei n 4.592, de 29 de dezembro de 1964, aprovou o "Plano Nacional de Viação" (BRASIL,2014).

O PNV de 1964 tinha como bases gerais o atendimento às necessidades socioeconômicas e político estratégicas estimadas para os próximos vinte e cinco anos, além da prioridade para vias e terminais de caráter nacional, da continuidade e revitalização aos troncos longitudinais rodoferroviários, bem como dos terminais portuários e aeroviários na faixa de $500 \mathrm{~km}$ no litoral, da ligação de Brasília, com as capitais estaduais. Previa a facilitação do escoamento da produção nacional entre os centros produtores e os grandes centros, o atendimento às necessidades estratégicas militares, inclusive, no acesso adequado às fronteiras terrestres e marítimas, e a integração do sistema de viação nacional com os sistemas pan-americano e internacional (BRASIL,1976).

O Conselho Rodoviário Nacional ficou incumbido de apresentar as emendas necessárias ao setor, observando as seguintes normas específicas:

- Classificar como rodovias federais aquelas que liguem Brasília a uma ou mais capitais dos Estados ou, ainda, a pontos da orla oceânica ou fronteira terrestre e também que liguem duas ou mais capitais estaduais a esses pontos; liguem duas ou mais rodovias federais para diminuir o tráfego interestadual; permitam o acesso a parques nacionais, indústrias, bases militares, estâncias hidrominerais, principais terminais marítimos, aeroviários e ferroviários.

- Não deveria sobrecarregar a malha rodoviária federal, para que os estados pudessem resolver sozinhos seus problemas relacionados ao setor rodoviário e

- Máximo aproveitamento da malha rodoviária já existente aprovada pelo Planos Rodoviário de 1957. 
Conforme a orientação geográfica, as rodovias foram classificadas como:

- Radiais - saindo de Brasília em qualquer direção, e que servem de ligação com as capitais estaduais e pontos periféricos do País.

- Longitudinais - orientadas na direção norte-sul;

- Transversais - orientadas na direção Leste-Oeste;

- Diagonais - orientadas na direção nordeste-sudeste e noroeste-sudeste;

- Ligações - que fazem ligação em qualquer direção, pontos importantes de duas ou mais rodovias para encurtamento de tráfego e as de acesso, responsáveis pelos acessos a importantes instalações federais e pontos turísticos, bem como a terminais marítimos, fluviais, aeroviários ou ferroviários.

Nessa classificação convém destacar a descrição da BR-010 (Brasília - Paraná - Carolina - Porto Franco - Guamá - Belém) com 1.901 km de extensão, como rodovia de penetração de caráter pioneiro, com vistas à integração econômica e a BR-153, classificada como rodovia longitudinal, com extensão de $3.749 \mathrm{~km}$. A rodovia que popularmente denominam como Belém-Brasília é composta pelas BR's 153, 010, 060 e 226, enquanto que a rodovia que oficialmente é a BelémBrasília é apenas a BR-010. Em 1965, com a publicação da Lei na 4.906, de 17 de dezembro, houve um acréscimo de aproximadamente $2.000 \mathrm{~km}$ de rodovias sobre a rede apresentada pelo PNV/1964, que já era de 18.000 km de extensão.

O Decreto-Lei $n^{\circ}$ 142, de 02 de fevereiro de 1967, promulgado pelo Presidente Castelo Branco, traz em seus artigos quase a totalidade do projeto original de $1964 \mathrm{e}$, consequentemente, revoga as Leis 4.592/64 e 4.906/65. Com isso, houve uma redução significativa do número de rodovias, que passaram de cento e trinta e duas para cento e nove, bem como de sua extensão global, que passou de $103.000 \mathrm{~km}$ para $89.000 \mathrm{~km}$ (BRASIL, 1976). O referido Decreto destacou-se também por apresentar uma racionalidade na adoção, distribuição e nomenclaturas das rodovias federais. Outro fato importante ocorrido neste ano de 1967 para o setor de transportes brasileiro foi a implantação de uma ampla reforma administrativa no país, estabelecendo, dentre outras diretrizes, a criação do Ministério dos Transportes, pelo Decreto-lei no 200, de 05 de fevereiro. (República, 1967). A inauguração do Ministério dos Transportes ocorreu no dia 15 de março de 1967, e, sob sua competência ficaram a coordenação dos transportes ferroviários, rodoviários e aquaviários, 
marinha mercante, a construção naval, portos e vias navegáveis e, também, parte da coordenação dos transportes aeroviários (BRASILEIRO, 2001).

A BR-010, que inicia em Brasília-DF e termina em Belém-PA, que entre outras cidades, inclui Pedro Afonso e naturalmente Itacajá em seu traçado, foi eliminada dos PNV em 1972/1973 pelo Presidente da República Garrastazu Médici.

Embora a BR-010 tenha sido eliminada do PNV em 1973, o Projeto de Lei nº 1.143/1973 recebeu as emendas 83 do Deputado Siqueira Campos e 109, dos, versando sobre o retorno da BR-010 ao PNV, a Emenda No 83 e a Emenda N 109, dos deputados Rezende Monteiro, Ary Valadão, Brasílio Caiado, Eurico Ribeiro e João Castelo. Estas emendas passaram a integrar a Lei 5.917 de 10 de setembro de 1973.

A Emenda $n^{\circ} 83$ acrescentou a rodovia radial BR-010 com o trecho de Brasília - Paranã - Carolina - Porto Franco - Guamá - Belém, justificando a sua manutenção no PNV pois o traçado previsto encurtaria a distância entre o extremo norte do país e a capital federal, em mais de $300 \mathrm{~km}$.

A Emenda $n^{\circ} 109$ incluiu outro trecho para a Rodovia BR-010: Brasília - Paranã - Carolina Estreito e apresentou como justificativa o fato de que, com a abertura da Rodovia Transbrasiliana, no trecho localizado entre os rios Araguaia e Tocantins, as áreas que se encontravam à margem direita do Rio Tocantins foram abandonadas, estendendo-se o referido abandono até o nordeste goiano. A inclusão da BR-010 tentaria corrigir o problema do isolamento da região trazendo progresso para o Estado de Goiás.

Segundo Anísio Brasileiro, o Plano Nacional de 1973 “... inovou ao incorporar princípios e normas de economia de transporte aplicáveis a todas as jurisdições com visão sistêmica nacional'. Relata o autor, que o trecho rodoviário federal, considerando-se trechos construídos e previstos, atingiu 111.944 km, tendo elaboração paralela dos Estados e Municípios na formulação de seus próprios planos (BRASILEIRO, 2001). Para Peixoto, a elaboração do PNV/1973 pode assim ser descrito:

Fora elaborado com o objetivo fundamental de promover o estabelecimento de infraestrutura de um sistema viário integrado capaz de atender pelo menor custo às necessidades de transportes exigidas pelo desenvolvimento e pela segurança nacional (PEIXOTO, 1977). 
O Plano Nacional de Viação de 1973, abrangeu os conceitos relativos aos sistemas nacionais rodoviários, ferroviários, aquaviários, portuários e aeroviários, com revisões previstas inicialmente de cinco em 05 cinco anos e teve sua vigência até 06 de janeiro de 2011. Nessa data foi, revogado pela Lei no 12.379, que criou o Sistema Nacional de Viação - SNV, composto pela infraestrutura física e operacional dos vários modos de transporte (rodoviário, ferroviário, aquaviário e aeroviário) de pessoas e mercadorias, sob a jurisdição dos diferentes entes da Federação e subdivide-se em Sistema Federal de Viação e sistemas de viação dos Estados, do Distrito Federal e dos Municípios, conforme TRANSPORTES (2014).

\subsection{INFLUÊNCIAS PRODUZIDAS PELOS TRANSPORTES NO CRESCIMENTO E DESENVOLVIMENTO ECONÔMICO DO BRASIL}

Segundo Peixoto (1977) a circulação dos indivíduos, das mercadorias e das informações multiplica as oportunidades de contatos econômicos e sociais entre os homens, sendo o mais poderoso fator de progresso humano e um dos principais índices do grau de civilização de um povo: "quanto mais rápidos, frequentes, fáceis e seguros forem os agentes da circulação, tanto mais adiantada será a civilização".

Fromm (1991) afirma que o sistema de transportes tem como objetivo garantir a disponibilidade de serviços de transporte rápido, seguro e econômico, fundamentais em uma economia em fase de crescimento e em constantes mudanças, a fim de movimentar bens de consumo e pessoas, sem causar danos e perdas a ambos, sem estragos ou discriminação, em resposta à procura pública e privada ao custo consistente com o bem-estar, a conveniência, a segurança nacional, e a outros objetivos públicos.

Apesar da mobilização para o desenvolvimento industrial ocorrido entre os anos de 1885 e 1930, com o desenvolvimento do sistema ferroviário, no Brasil o despertar para o crescimento econômico está relacionado ao transporte rodoviário, que tomou impulso no mundo a partir da II Grande Guerra Mundial, (BARAT, 1991):

O surto de industrialização que se seguiu à Segunda Guerra Mundial deve ser analisado à luz de um complexo conjunto de fatores políticos, institucionais e econômicos. A análise do crescimento industrial deve ser complementada, de forma sumária, com uma visão panorâmica da evolução de alguns outros setores industriais importantes. Entre 1958 e 1970, finalmente, a produção nacional de veículos automotores cresceu de quase 7 vezes. Com relação ao crescimento da 
produção automobilística, o lado do vertiginoso incremento na escala de produção e da rápida conquista de índices de nacionalização superiores a $95 \%$.

Conforme o referido autor, nos anos de 1930 e 1940, foram concedidos incentivos regulamentares e institucionais ao transporte. Com a criação do Departamento Nacional de Estradas e Rodagens (DNER) tornou-se possível a capacitação e a expansão das rodovias, bem como a diversificação dos fluxos de produção manufaturada.

Desde o começo de sua expansão por meio das rodovias, o Brasil tem sofrido com a falta de uma política que vise a distribuição e a integração dos modais de transporte. Um dos fatores que mais contribuem com a ausência desta integração é a descontinuidade espacial no que diz respeito ao suporte à consolidação de uma economia nacional com a autonomia dos polos de economia primário-exportador (BARAT, 1991), em detrimento ao quadro real da economia do país, onde os pólos exportadores regionais integram-se diretamente aos principais centros industriais asiáticos, norte-americanos e europeus, que, de um lado, eram os grandes consumidores da sua produção de matérias-primas e alimentos e, de outro, os fornecedores das suas necessidades de produto manufaturados.

No que tange à implantação de infraestrutura de transportes e o processo de apropriação do território nacional, houve uma resposta econômica que pode ser descrita como uma exploração degradante, desenfreada e sem planejamento. As políticas públicas estabelecidas deveriam ter sido organizadas e ter estabelecido regras na perspectiva do fluxo migratório e ocupação do solo, pois as pessoas se aglomeravam por interesse econômico proporcionado, e formavam cidades, sem um planejamento prévio. Sobre esse assunto Barat (2007) destaca também a falta de complementariedade entre os diferentes modais, após o fim de ciclo primário exportador e o colapso da integração ferrovia porto navegação.

Segundo Owen (1975), a revolução dos transportes do século XX nos deu a consciência da relação entre a imobilidade e a pobreza". Nesse sentido, a imobilidade é verificada na economia quando tempo e energia são desperdiçados em áreas do mundo subdesenvolvido, por falta de mecanização dos meios de condução. Para este autor, a proximidade entre imobilidade e pobreza diz que vislumbrando a ausência de transporte em uma região, ou ainda, a deficiência dele, a maior parte dos recursos mundiais permanece intocados, já que não há meios de atingi-lo. Acrescenta ainda o autor que, fabulosos recursos minerais e florestais, que poderiam contribuir na luta contra a miséria, 
não são utilizados porque ninguém pode chegar até eles, sobretudo transportá-los, a exemplo da cidade de Itacajá, analisada na presente pesquisa.

As implicações do transporte na economia mostram-se com maior ênfase, à medida que, diante de sua ineficácia, aumenta cinco vezes o valor dos produtos em relação ao custo original. Mais que isto, conforme estudos realizados por (OWEN,1975):

As dificuldades de transporte têm seu impacto político e social, assim como econômico. O transporte deficiente dificulta sobremaneira a efetivação da integração nacional, pois o processo de crescimento é retardado pela limitada possibilidade de aos administradores governamentais viajarem através do seu país e pelas dificuldades de se conduzir negócios. Ele também limita a eficiência dos programas de assistência técnica e econômica.

A ligação dos transportes com a economia do Brasil é algo tão antigo, que ao mencionar história do povoamento da região do Tocantins pelos índios, Mellati (1967) afirmou que a área de criação agrícola não necessitava tanto de suas próprias mercadorias produzidas, mas especialmente dos artigos que eram recebidos pelos portos de mar, tais como sal, instrumentos de ferro, utensílios domésticos, dentre outros.

No século XVIII, houve uma abertura de caminhos a oeste do Tocantins, a fim de favorecer os primórdios da navegação comercial. O transporte de gado, com a abertura da estrada Transbrasiliana, foram-se modificando as relações de produção. A motivação para reabertura da estrada relaciona-se ao fato de que, em virtude de seu fechamento suspendeu-se o corte de gado em Marabá e as charqueadas de gado (MELATTI,1967). É sabido que o transporte, em sentido geral, bem como sua política, em determinadas regiões do país, possibilita modificações nos arranjos sociais, mais especificamente na dinâmica econômica que se estabelece em diversos espaços.

O transporte rodoviário é um bem que viabiliza tanto o crescimento quanto o desenvolvimento econômico de um país, pois existe, notadamente, uma estreita relação dos transportes com o IDH, que trata da qualidade de vida das pessoas. Além disso, o PIB espelha o acúmulo de riquezas. O transporte num país em estágio de desenvolvimento, é um bem dos que mais consome recursos em sua fase de implantação. Embora, quando bem planejado, não diminua o acúmulo de capital. Vale salientar, de um ponto de vista mais amplo, que ele representa uma espécie de investimento diversificado do crescimento geral de uma economia. O transporte rodoviário não só permite 
estímulos relacionados à atividade diretamente produtiva, através do seu impacto econômico, como também permite outras atividades relacionadas ao desenvolvimento e a outras atividades não relacionadas diretamente à atividade econômica. Obviamente que para tal desenvolvimento ocorra, torna-se necessário a integração do desenvolvimento econômico aos transportes (FROMM, 1968).

Para Barat (1991) a integração entre o setor de transportes e o desenvolvimento mais harmonioso e integrado aos níveis nacional, regional e urbana. Somente terá êxito mediante planos, programas e projetos que combinem objetivos múltiplos de natureza econômica e local. Os transportes deverão ser, inclusive, mais indutores do que corretivos na ocupação do território e facilitar o escoamento da produção agrícola, a implantação das indústrias e a distribuição de seus produtos, bem como a movimentação das pessoas nas ligações entre residência, trabalho, escola e lazer.

O transporte rodoviário, associado à tecnologia pode desempenhar um papel de múltiplas facetas na consecução dos objetivos do crescimento urbano e rural. De acordo com Fromm (1968), uma de suas funções, é como elemento balizador e produtor de receita e de permitir que mercadorias e passageiros sejam transferidos entre os centros de produção e consumo. Parte desse movimento ocorre também no meio rural, no qual o transporte propicia equilíbrio por meio da fixação de pessoas em seus locais de origem. Com a permanência do agricultor no meio rural, evita-se, dessa forma, o inchaço dos centros urbanos causando problemas sociais como o desemprego e a falta de moradia, dentre outros. Com isso, é possível ainda um incremento à economia da região. No entanto, torna-se necessário um transporte acessível e eficiente que permita o deslocamento das pessoas na zona rural.

Barat (2007) afirma que os transportes, quando usados como atividade-meio ou como suporte à produção de bens e serviços são vitais para o aproveitamento da capacidade produtiva de um país ou região. Estão na linha de frente as questões ligadas ao desenvolvimento econômico, à geração de emprego e renda, à ocupação do espaço territorial, ao meio ambiente e à produção de energia. E todos esses fatores são fundamentais na formação de capital, na concentração de empresas, por possuírem características semelhantes ou parecidas, na ocupação de mão de obra, e no consumo de insumos energéticos e nos eixos de desenvolvimento.

\subsection{ATIVIDADE ECONÔMICA VERSUS TRANSPORTES}

A necessidade de transportes no território nacional apoia-se no relacionamento entre o dispêndio 
da nação e o volume total do movimento de bens que as mais variadas atividades econômicas envolvem. Referida premissa pode ser comprovada por meio do conhecimento acerca do Produto Nacional Bruto (PNB) e das estatísticas dos transportes, sendo possível estimar as prováveis demandas de transportes (OWEN, 1975).

De acordo com os dados fornecidos pelo Conselho Nacional de Transportes - CNT (2006), a existência de outros pólos urbanos distribuídos no interior, confere ao Estado razoável distribuição regional, sendo que os 645 municípios que compõem o Estado, mantém indústrias, produções agropecuárias e serviços interligados por uma malha rodoviária considerada como sendo a melhor do país, demonstrado nos resultados do Relatório Gerencial da Confederação Nacional dos Transportes. Nesse sentido, a malha rodoviária que atende São Paulo torna verdadeiro o crescimento do mercado consumidor interno e externo, ampliando a produção nos próximos anos e impactando na distribuição das riquezas. Na perspectiva de analisar como os fluxos econômicos mobilizam os transportes, justificando-se a relação entre eles, em meio à geografia econômica, a linha de pensamento de Alfred Weber é favorável porque evidencia a relação hierárquica entre cidades e baseia-se na economia de escala e na otimização dos custos de transporte (ICHIHARA, 2007).

A partir da teoria de Weber, ou seja, da análise de insumo-produto, as redes de transportes são gerenciadas em acordo com os modelos de economia regional, destacando-se o objetivo de melhorar a rede de transportes para atender às demandas de consumo. $\mathrm{O}$ fluxo de transportes de uma rodovia em função da demanda é determinado pela oferta econômica prevista. E desse equilíbrio previsto no planejamento tem-se como resultado o equilíbrio na economia (LEONTIER e STROUT, 1963).

No próximo capítulo, serão abordados dados históricos e socioeconômicos do município de Araguaína e dos municípios que serão utilizados na comparação com a cidade objeto deste trabalho, dando subsídio ao estudo da relação existente entre este Município e a rodovia federal BR-153, ressaltando também a importância da referida BR para a economia de Araguaína. 


\section{HISTÓRIA, GEOGRAFIA, TRANSPORTE E CRESCIMENTO POPULACIONAL DE ARAGUAÍNA E CIDADES CORRELATAS}

Para se fazer menção às cidades tocantinenses torna-se necessário apresentar brevemente a história do estado, pois todo processo de transformação das cidades transcorreu na antiga formação territorial goiana, exceto a capital Palmas, que foi construída a partir da criação do estado em 1988.

Em 1987, a Comissão de Estudos dos Problemas do Norte (CONORTE) apresentou à Assembleia Constituinte uma emenda popular com cerca de 80 mil assinaturas como reforço à proposta de criação do Estado. Por interesse popular e colaboração política, o estado foi criado por meio do artigo 13 do Ato das Disposições Constitucionais Transitórias da Constituição em 05 de outubro de 1988 (BRASIL, 2014).

A primeira Constituição do Estado, promulgada em 5 de outubro de 1989 nos moldes da Constituição Federal, criou mais 44 municípios, além dos 79 já existentes. Atualmente, o Tocantins possui 139 municípios divididos em 8 microrregiões do estado brasileiro (IBGE, 2015). No centro geográfico do Estado foi construída a capital Palmas, numa área de $1.024 \mathrm{Km}^{2}$, desmembrada do município de Porto Nacional, para ser a sede do governo estadual. Em $1^{\circ}$ de janeiro de 1990 foi instalada a capital (IBGE, 2015).

De acordo com o IBGE (2015), sob aspecto político, conforme Figura 4.1, as mesorregiões do estado do Tocantins são formadas por 8 microrregiões no estado brasileiro, onde estão distribuídas as 139 cidades, Araguaína com 17 municípios, Bico do Papagaio com 25, Dianópolis com 20, Gurupi com 14, Jalapão com 15, Miracema do Tocantins com 24, Porto Nacional com 11 e Rio Formoso com 13. 


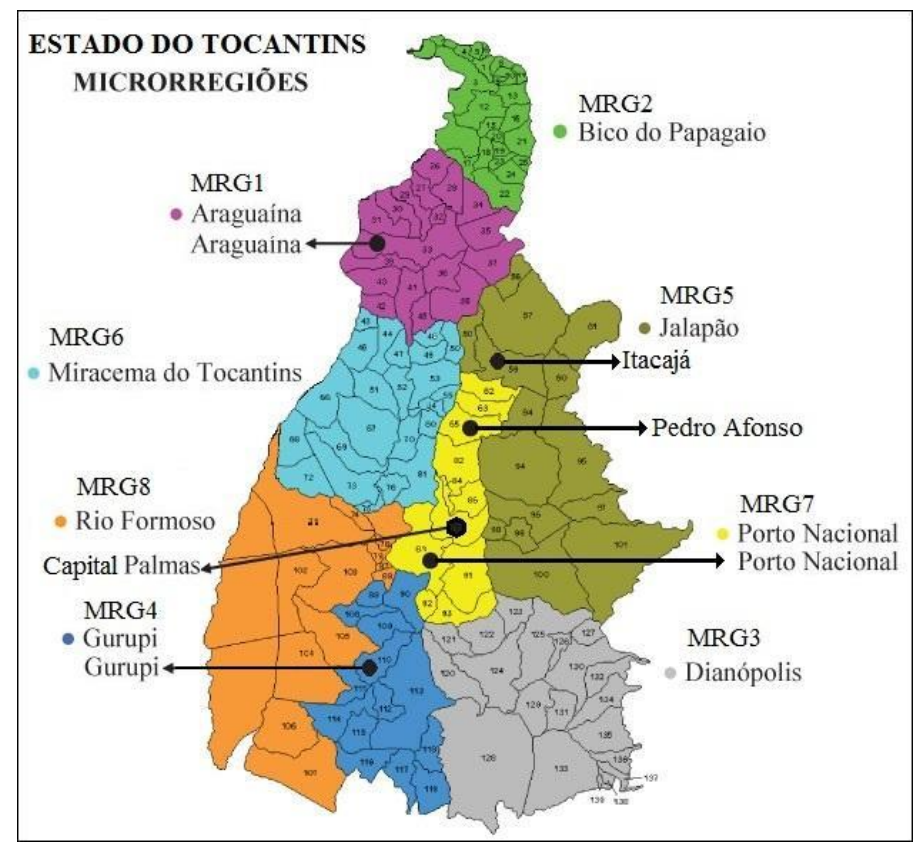

Figura 4.1: Estado do Tocantins e suas Microrregiões Fonte: Parisel, et al., (2010)

A microrregião de Araguaína é a segunda maior na concentração da população tocantinense com cerca de $20 \%$, sendo a primeira, a região central de Porto Nacional, que concentra em torno de $23 \%$ da população tocantinense. Tais números devem-se ao fato de as maiores cidades do estado, Palmas, na microrregião de Porto Nacional, com 228.297 habitantes e Araguaína, na microrregião de Araguaína, com 150.484 habitantes (Tabela 4.1) estarem localizadas nessas duas regiões.

Tabela 4.1: Distribuição populacional nas microrregiões do Tocantins

\begin{tabular}{|c|c|c|c|c|}
\hline Posição & Nome da Microrregião & Área em km² & $\%$ & $N^{o}$ de \\
\hline 1 & Bico do Papagaio & $15.767,856 \mathrm{~km}^{2}$ & 15 & 25 \\
\hline 2 & Araguaína & $26.493,499 \mathrm{~km}^{2}$ & 20 & 17 \\
\hline 3 & Miracema do Tocantins & $34.721,860 \mathrm{~km}^{2}$ & 11 & 24 \\
\hline 4 & Jalapão & $53.416,435 \mathrm{~km}^{2}$ & 5 & 15 \\
\hline 5 & Porto Nacional & $21.197,989 \mathrm{~km}^{2}$ & 23 & 11 \\
\hline 6 & Rio Formoso & $51.405,340 \mathrm{~km}^{2}$ & 8 & 13 \\
\hline 7 & Gurupi & $27.445,292 \mathrm{~km}^{2}$ & 10 & 14 \\
\hline \multirow[t]{2}{*}{8} & Dianópolis & $47.172,643 \mathrm{~km}^{2}$ & 9 & 20 \\
\hline & Total & $277.621,858 \mathrm{~km}^{2}$ & 100 & 139 \\
\hline
\end{tabular}

Fonte: IBGE (2014, adaptado pelo autor)

Nas maiores microrregiões em área, que são Jalapão, com uma área de 53.416,435 km², concentrando apenas 5\% da população e Rio Formoso, numa área de 51.405,340 km², concentrando $8 \%$ da população, estão as menores taxas populacionais. 
Pelo fato de as microrregiões que formam o estado do Tocantins não serem objeto de estudo deste trabalho, elas foram apresentadas, tão somente, para demonstrar a estrutura político-administrativa do estado do Tocantins e também, para se conhecer a microrregião em que cada cidade aqui evidenciada encontra-se inserida. Conforme IBGE (2010), as cidades de Araguaína, Gurupi e Itacajá, pertencem, respectivamente, às microrregiões de Araguaína (MRG1), Gurupi (MRG4) e Jalapão (MRG5); as cidades de Pedro Afonso e Porto Nacional pertencem à Microrregião de Porto Nacional (MRG7).

\subsection{ASPECTOS DAS CIDADES DE GURUPI, PORTO NACIONAL, PEDRO AFONSO E ITACAJÁ, REFERÊNCIA NA COMPARAÇÃO COM ARAGUAÍNA}

Das cidades apresentadas, duas foram fundadas na mesma década que Araguaína, Gurupi e Itacajá, década de 50, sendo que Gurupi e Araguaína estão às margens da BR-153 e Itacajá às margens da BR-010 e outras duas, Pedro Afonso e Porto Nacional, não estão às margens de rodovia longitudinal e nem radial, mas são ribeirinhas, estando a primeira próxima ao bicentenário e a segunda com mais de um bicentenário de idade.

Tendo em vista que os estudos deste trabalho estão focados em Araguaína (cidade principal) e as abordagens histórico-sócio-econômicas serem maiores, muitos dados das demais cidades foram apresentados juntamente com os dados de Araguaína, no intuito de dar suporte às análises comparativas com esta e também, a partir dela, mostrar no capítulo 6, uma análise e avaliação da influência da implantação da BR-153 no desenvolvimento e crescimento de Araguaína. Por esta razão as cidades Gurupi, Porto Nacional, Pedro Afonso e Itacajá, serão apresentadas primeiro.

\subsubsection{Gurupi}

Apesar de ter a mesma idade de Araguaína, das cidades apresentadas, Gurupi é a que tem a história mais recente, desde sua fundação. Conforme consta no histórico do município, IBGE (2014), a adentrada na região foi ocasionada por Benjamim Rodrigues em 1932, quando procurava por uma tropa de muares que escapara do município de Peixe às margens do rio Tocantins. Sua ocupação veio mesmo ocorrer 14 anos mais tarde por exploradores oriundos de Dueré, Porto Nacional e cidades geralmente do norte do estado, dando início a formação do arraial.

Ainda, conforme constam nos relatos do IBGE (2014), concorreu fortemente para o desenvolvimento do município a inclusão de Gurupi no projeto da rodovia Transbrasiliana, BR- 
153, quando se fez uma planta rústica da cidade, com localização da igreja matriz e a abertura das principais avenidas.

A agropecuária foi a grande promotora das transformações ocorridas com a constante chegada de aventureiros e colonos e com o crescimento das lavouras e da criação de gado; as cabanas de pau a pique e ranchos de sapé foram cedendo lugar a construções sólidas com alvenarias, ainda no início do ano de 1950. Em 1956, elevou-se o povoado a Distrito pertencente a Porto Nacional e, em 1958, alcançou sua emancipação político-administrativa, dando-se a instalação no ano seguinte (IBGE, 2014).

Gurupi está localizada nas coordenadas latitude $11^{\circ} 43^{\prime} 45^{\prime \prime}$ sul, longitude $49^{\circ} 04^{\prime} 45^{\prime \prime}$ oeste, a 223 km de Palmas/TO e 742 km de Brasília/DF, posicionada ao sul, na microrregião do "Gurupi”. Possui uma área de $1.836 \mathrm{~km}^{2}$; em seus limites estão os municípios: Aliança do Tocantins, Cariri do Tocantins, Dueré, Figueirópolis, Peixe e Sucupira.

A microrregião tocantinense a que a cidade de Gurupi pertence também é denominada de Gurupi, com 137.217 habitantes em 2010 e divide-se em quatorze municípios: Aliança do Tocantins, Alvorada, Brejinho de Nazaré, Cariri do Tocantins, Crixás do Tocantins, Figueirópolis, Gurupí, Jaú do Tocantins, Palmeirópolis, Peixe, Santa Rita do Tocantins, São Salvador do Tocantins, Sucupira e Talismã.

Conforme dados econômicos e sociais, IBGE (2014) e SEPLAN-TO (2014), Gurupi é a terceira maior cidade do Tocantins em termos populacionais e econômicos; sendo o polo regional da região sul do estado, sua base econômica está sob serviços correspondendo a 67,7\% do PIB, seguido pela indústria com 27,9\% e agropecuária com 4,4\%. Possui escolas estadual de ensino fundamental, médio e campus universitários, com destaque para a Universidade Federal do Tocantins UFT e Centro Universitário Regional de Gurupi (UNIRG).

O sistema se transporte no município é composto por rodovias, aeroporto e ferrovia. Apesar da existência dos três modais, o mais usado para o transporte de carga é o rodoviário, tendo como principal rodovia a BR-153, que faz interação do município com as regiões Norte e Sul do Brasil. As demais rodovias, as quais fazem interação do município com outras localidades são a TO-365, que interliga o município de Gurupi a Porto Nacional e Palmas; TO-374 e acessa as partes do 
interior do Tocantins e também a estrada de rodagem federal BR-242, transversal que interliga Gurupi a Maragogipe, no litoral baiano, próximo a Salvador e também a Sorriso/MT (MT, 2015).

O transporte aéreo não faz concorrência com o transporte rodoviário no que diz respeito à movimentação de cargas, visto que possui apenas uma empresa operando com vôos regulares no transporte de passageiros, a SETE, que faz vôos para Brasília, Goiânia, Palmas e cidades do interior de Goiás, Tocantins e Mato Grosso. No município não há empresa aérea operando com transporte de cargas.

A ferrovia presente no município é a EF-151, denominada Ferrovia Norte-Sul (FNS), com 1.574 km construídos entre Açailândia/MA e o Porto Seco de Anápolis/GO, sendo apenas $719 \mathrm{~km} \mathrm{em}$ operação, que vai de Açailândia a Palmas, segundo VALEC (2014). Apesar de ser recente o início das operações do transporte de carga no modal ferroviário, este já transporta commodities agrícolas, fertilizantes, combustíveis e containers com cargas em geral.

Ainda está em construção e em estudo de viabilidade (EVTEA) a ferrovia EF-334, denominada Ferrovia de Integração Oeste-Leste (FIOL), que será interligada à FNS no pátio multimodal de Gurupi, através de Figueirópolis/TO. A FIOL fará conexão de Gurupi ao porto de Ilhéus/BA passando por todo o oeste baiano, o qual se destaca por ser um dos maiores polos produtores de grãos do país, segundo VALEC (2014).

\subsubsection{Porto Nacional}

Das cidades em tela, Porto Nacional é a mais antiga, uma das mais antigas do Tocantins, que surge à beira do rio Tocantins por interesses econômicos dos exploradores de ouro. De acordo com relatos expressos no sítio eletrônico do IBGE (2015), a exploração do minério, iniciada em 1722 é responsável pela formação da maioria dos povoados que se estabeleceram na região da então província de Goyaz, onde está fixado Porto Nacional, que, na época de sua descoberta, era denominada de Porto Real do Pontal.

Conforme IBGE (2014), o núcleo formador da cidade foi fundado em meados 1738 com a fixação de morada do português Félix Camôa, que explorava a travessia do rio de mineradores, mascates, tropeiros, transeuntes, aventureiros e viajantes. 
(...) não tardou que outros barqueiros aproveitassem a ideia do pioneiro lusitano e também comercializassem a travessia dos chegantes. Dessa forma, ao aproximarse o início do século XIX, inúmeros casebres começaram a desenhar um pequeno aglomerado humano, abrigando ali agricultores, pescadores, trabalhadores preparados para o transporte de cargas em direção aos dois arraiais, e mineradores, muitos mineradores, na busca diuturna das mais espetaculares pepitas de ouro já encontradas na região, segundo PMPP (2015).

Quando, em 1791, o cabo Thomaz de Souza Villa Real, verificava a possibilidade de navegação e do estabelecimento de uma rota comercial sul-norte, instalou-se um destacamento militar na região (IBGE, 2015).

Com a exploração do comércio, da navegação e, naturalmente, com o despertar econômico em 14 de novembro de 1831, ano em que D. Pedro I abdicou ao trono, o Julgado de Porto Real foi elevado à Vila de Porto Imperial, segundo PMPP (2015). Conforme IBGE (2014), os principais fatores que contribuíram para a sua elevação à sede de município foram:

- incremento da navegação do Tocantins e do comércio com Belém do Pará, - declínio da mineração nas localidades vizinhas, como Pontal,

- desenvolvimento da criação de gado.

Segundo informação encontrada no sítio eletrônico da Prefeitura Municipal de Porto Nacional (PMPP,2015), em 13 de julho de 1861 pela Resolução Provincial nº 333, o governo da Província de "Goyaz" eleva Porto Real à condição de Cidade. No histórico de Porto Nacional, Porto Real já era um importante empório comercial, com muitos comerciantes, comércio fluvial intenso com a região Norte; era o mais importante polo cultural, político, econômico e social do então norte goiano; apresentava população de 4.313 habitantes e a existência de três escolas para alunos do sexo masculino e uma para estudantes do sexo feminino.

Com a Proclamação da República a cidade passa a se denominar de Porto Nacional (RODRIGUES, 1945).

Ainda sobre os aspectos econômico e sociais, na história recente de Porto Nacional, antes da construção da BR-153 e FNS, paralelas ao rio Tocantins, Rodrigues (1945) expõe que:

Colocada em ótima situação, Pôrto Nacional progride rapidamente, exercendo Poderosa influência no progresso da região tocantina, sendo o centro da linha base da marcha para o oeste da civilização. Seu aeroporto, suas estradas carroçáveis para Tocantínia, Barreiras (Bahia), Natividade, e Palma, os garimpos de cristal, a mineração de ouro, enfim os mil e um dos fatores que regem seu progresso, 
sobretudo suas escolas, deixam entrever o desenvolvimento vertiginoso que há de ter muito breve.

O município está a 70 km da capital do estado, 745 km de Brasília/DF e 765 km de Goiânia/GO, na posição geográfica definida pelo paralelo Latitudinal 10 $40^{\circ} 28^{\prime \prime}$ em interseção com a Longitudinal $48^{\circ} 25^{\prime} 01^{\prime}$, pertencente a microrregião de "Porto Nacional" no estado do Tocantins. Possui uma área de $4.450 \mathrm{~km}^{2}$; em seus limites estão os municípios tocantinenses de Miracema do Tocantins, Palmas, Monte do Carmo, Silvanópolis, Ipueiras, Brejinho de Nazaré, Fátima, Oliveira de Fátima, Nova Rosalândia, Pugmil e Paraíso do Tocantins.

A cidade de Porto Nacional, pertence a microrregião brasileira de Porto Nacional, composta pelas cidades Aparecida do Rio Negro, Bom Jesus do Tocantins, Ipueiras, Lajeado, Monte do Carmo, Palmas, Pedro Afonso, Porto Nacional, Santa Maria do Tocantins, Silvanópolis e Tocantínia; a microrregião de Porto Nacional é a que tem o maior número de habitantes: 322.824; desses, 41\%, pertencem apenas a capital do estado, Palmas.

Os dados municipais extraídos do SEPLAN-TO (2014) apresentam Porto Nacional como sendo a quarta maior cidade do Tocantins, tanto em número de habitantes quanto pela taxa do PIB; o setor de serviços foi responsável por 49,5\% do valor adicionado, indústria 39,37\% e agropecuária 11,08\%. A atividade econômica com maior efeito no PIB é o setor de serviços; deste setor, a maior contribuição vem da administração pública; na indústria é a construção civil e na agropecuária é a soja cana-de-açúcar, mandioca, feijão.

Ainda sobre os indicadores econômicos, o IDHM, a dimensão com maior expressão é a longevidade, representando $37 \%$ do índice; seguido pela educação e renda, com 32\% e $31 \%$, respectivamente. Possui escolas de ensino fundamental, médio e faculdades de ensino superior, com destaque ao Instituto de Ensino Superior de Porto Nacional, o qual possui o curso de Medicina, curso em pouquíssimas cidades do estado.

A composição do sistema de transporte de Porto Nacional é formada por rodovias, ferrovia e aeroporto, a hidrovia, que foi o maior corredor de transporte de cargas e passageiros, rumo ao Norte do país e deixou de ser utilizada em função do transporte rodoviário com a construção da rodovia federal BR-153 e ponte sobre o rio Tocantins, em 1979, fazendo com que a cidade voltasse a crescer com maior expressão tanto nos aspectos populacionais quanto econômicos. 
As rodovias presentes no município são: TO-050, a principal via de acesso no sentido Norte-Sul e a que conduz a Palmas; TO-255, que atravessa o município no sentido Leste-Oeste e a principal via de acesso, a BR-153. Ainda fazem parte do município as rodovias TO-040, TO-458, TO-454 e TO-455, sendo que a TO-454 em leito natural e a TO-458 em pavimentação, conforme SEPLANTO (2014).

Também está presente no município a ferrovia EF-151, com o denominado Pátio Multimodal de Porto Nacional à margem da rodovia TO-336, que é utilizada para o transporte de parte das commodities agrícolas, fertilizantes, combustíveis, containers com cargas em geral, com contrato de arrendamento firmado com sete empresas, conforme VALEC (2014).

No sistema aeroviário, apesar de possuir o primeiro aeroporto construído no estado, não há companhia aérea para operar no município, sendo necessário utilizar-se dos serviços de taxi aéreos e de cargas de Palmas.

\subsubsection{Pedro Afonso}

A cidade de Pedro Afonso, assim como Porto Nacional, é também uma cidade Ribeirinha, na confluência dos rios Tocantins e Sono, pertencente ao grupo das cidades mais antigas do Tocantins se aproxima do bicentenário. Antes, fora dominada pelos índios Xerentes, e mais tarde, após a chegada de um padre capuchinho, para somar aos já existentes indígenas da região, vem do município de Riachão/MA os índios Craôs (MELLATI, 1967).

Diferentemente das cidades de Porto Nacional, Gurupi e Itacajá, que nascem por interesses econômicos, Pedro Afonso nasce por interesse religioso como afirma (RODRIGUES, 1945).

Foi em julho de 1845 que o capuchinho italiano frei Rafael Targgia veio ao ponto onde hoje é Pedro Afonso, catequisar os índios Cherentes, trazendo em sua companhia uma escolta de dez praças, para garantia da povoação que ia criar, no lugar então chamado "Travessia dos Gentios".

Em pouco o arraial progredia, havendo uma capelinha, as barracas dos soldados e algumas casas de taipa, sendo conhecido por "Arraial do Rio Sono" (RODRIGUES, 1945).

Segundo Rodrigues (1945), por saberem das ricas pastagens daquela zona e da existência de terras devolutas, em breve, fazendeiros do Piauí e Maranhão foram sendo atraídos para formarem suas 
fazendas na região. Tal foi o progresso que, em 23 de agosto de 1853, a região era elevada à categoria de Distrito de Paz e, logo a seguir em 1858, eleva-se a Distrito Administrativo pela lei provincial $n^{\circ} 546$, que lhe muda o nome para Pedro Afonso.

Pela Lei $n^{\circ} 801$ de dezembro de 1887, foi restabelecida a Vila, cuja instalação se deu a 14 de julho de 1888. Pela Lei $\mathrm{n}^{\circ}$ 179, de 25 de julho de 1898, Pedro Afonso transformou-se em município, conforme GOIÁS (2013).

Além do município beneficiar-se da agricultura e da pecuária, em 1910, um dos maiores fatores de prosperidade é a corrida pela borracha do Araguaia. O estado da Bahia, nessa época, fazia suas transações comerciais com o Baixo Araguaia, servindo-se do rio Sono para fazer o escoamento de seus produtos, onde eram desembarcados e, muitas vezes vendidos aos comerciantes locais, com uma redução de 30 a 40\% sob os importados de Belém/PA e de São Luís/MA, que vinham pelo rio Tocantins, tornando-se destaque e maior empório comercial da época no alto sertão (IBGE, 2014).

Pedro Afonso, por aproximados 20 anos, entre 1913 a 1930, por questões políticas, passa pela fase mais escura de sua economia e história, iniciada por baianos cangaceiros que ensanguentaram e assolaram a região, saqueando o comércio, incendiando casas, tomando, roubando gado e praticando as maiores atrocidades até 1922.

Com o intuito de acabar com o banditismo, o governo estadual manda para lá um sargento sanguinário para manter a ordem, o qual pôs em prática o terror nas piores condições em que fora praticado pelos cangaceiros baianos (RODRIGUES, 1945).

Em 1930, findado o período da atuação dos baianos e militares, a cidade, privilegiada por estar nas confluências dos dois rios em condições de navegabilidade, volta a ser próspera, reergue suas casas, monta suas fazendas, abre seu comércio com a ação benéfica do governador Pedro Ludovico Teixeira, que estabelece a ordem e dá vigoroso impulso a Pedro Afonso (RODRIGUES, 1945).

Rodrigues (1945), afirma que:

O surto progressista atual de Pedro Afonso é notável, mais ativado pelos garimpos próximos em franca exploração (...).

Impõe-se, porém a mudança dos índios Craôs dessa região, pelo perigo que representam. Breve, Pedro Afonso terá lugar de destaque na economia nacional, pois procura já industrializar-se. 
Pertencente à microrregião de Porto Nacional no estado do Tocantins, nas coordenadas geográficas latitude $08^{\circ} 58^{\prime} 03$ " sul, longitude 48 $10^{\prime} 29^{\prime}$ " oeste, Pedro Afonso possui uma área de 2.010,90 km² e faz limite com as cidades Bom Jesus do Tocantins, Tupirama, Rio Sono, Tocantínia, Centenário e Rio dos Bois. Distante de Palmas 173 km, Araguaína 253 km, Goiânia 866 km, Brasília 758 km e Guaraí 40 km; dentre as metrópoles, possui maior interação comercial Goiânia, apesar de estar mais próxima a Brasília.

De acordo com a SEPLAN-TO (2014) e IBGE (2014), o PIB municipal no estado em 2010 ocupa $13^{\mathrm{a}}$ posição no ranking, sendo que a maior participação deste vem de serviços com 56,4\%, seguido pela agropecuária com 33,79\% e indústria com 9,85\%. O município ocupa a $17^{\mathrm{a}}$ posição em números populacionais com o $7^{\circ}$ PIB per capita e IDH-M dos 139 municípios de seu estado. Quanto ao IDH-M a maior participação vem da Longevidade com 38\%, seguida da Renda com $32 \%$ e Educação com $30 \%$.

Desde a fundação e durante anos, o transporte em Pedro Afonso era feito por vias navegáveis. Após a construção da BR-153 e pelo fato de as cidades com maior interesse econômico estarem às margens da rodovia, o transporte passou a ser rodoviário. No período de adaptação dos meios de transporte, a cidade teve significativas perdas socioeconômicas e populacional, período que compreende desde o início da construção da rodovia BR-153 até os anos 80 .

Com o cognome de "Capital da Soja do Tocantins", Pedro Afonso faz o escoamento da produção e ligação com outras regiões pelas rodovias TO-010 e BR-235/TO-336, que interliga o município à BR-153; além das rodovias também escoa o excedente, através da ferrovia EF-151, utilizando o Terminal Multimodal de Guaraí/TO, o qual localiza-se a $40 \mathrm{~km}$ de Pedro Afonso, que transporta commodities agrícolas, fertilizantes, combustíveis e carga em geral através de containers, em cujo terminal operam apenas duas empresas. Não possui aeroporto; compartilha uma pista de pouso do município de Tupirama/TO, distante $4 \mathrm{~km}$ de Pedro Afonso; para voos regulares, a população desloca-se para Palmas ou Araguaína.

Ainda sobre os aspectos econômicos e sociais a cidade de Pedro Afonso é dotada de escolas de ensino fundamental, médio, técnico com formação em Agropecuária, Açúcar e Álcool, Zootecnia 
e Logística e uma faculdade com bacharelado em Administração e tecnológico em Tecnologia em Agroindústria.

\subsubsection{Itacajá}

Itacajá, cidade com idade aproximada de Araguaína e Gurupi, fundada na mesma década, no ano de 1953, às margens do rio Manoel Alves Pequeno, afluente do rio Tocantins, também às margens da BR-010 e TO-239, ambas em trecho com leito natural, pertence a microrregião brasileira do Jalapão. A população do Jalapão, estimada em 65.705 habitantes, está dividida em quinze municípios com uma área total de $53.416,43 \mathrm{~km}^{2}$ desta área, Itacajá ocupa 3.051 km²

Conforme Rodrigues (1945), a descoberta e ocupação da região onde é situada a cidade de Itacajá está relacionada a fatores econômicos. Iniciou-se em meados do século XIX por duas grandes famílias, Correia do estado do Piauí e Soares do Maranhão, cabendo ressaltar que entre ambas houve enlaces matrimoniais e numerosa prole.

Conforme Mellati (1967), são três os principais motivos pela atração por essa região: as secas no estado do Piauí, o esgotamento das terras no Maranhão e o sistema de arrendamento vigente nos dois estados, aonde os proprietários de terras exigiam de seus agregados a entrega de cerca da quarta parte da produção. Esses agregados procuraram escapar de tais condições e seguiram rumo ao norte do Goiás, onde podiam ocupar uma porção de terra mediante uma taxa irrisória paga ao município de Pedro Afonso ou mesmo sem nenhuma contribuição.

No início do século passado, na posição geográfica onde está a cidade, era uma das fazendas do sr. Agostinho Ferreira Soares e se tornou um pequeno povoado denominado de Passo do Agostinho, formado por familiares deste fazendeiro e novos aventureiros atraídos por esse "eldorado" capaz de transformar homens com modestos recursos em grandes fazendeiros ${ }^{4}$.

Com a liberação de espaço por Agostinho em sua fazenda e formação do povoado, por volta de 1930, o que era chamado de Passo do Agostinho, passou a ser chamado de Porto do Vau, pelo fato de, no período de seca, o rio dar passagem a vau. Logo abaixo do Porto do Vau, na Fazenda Barriguda, de propriedade de Honorato Correia, ficava o $4^{\circ}$ distrito fiscal de Pedro Afonso. Com a colaboração do pastor Francisco Colares, este distrito fiscal foi transferido para o Porto do Vau,

\footnotetext{
${ }^{4}$ Era considerado um grande fazendeiro quem conseguisse o acúmulo de aproximadamente 600 reses (Melatti, 1967)
} 
dando origem ao núcleo urbano Vila de Itacajá em 1938 (MELATTI, 1967).

A atividade econômica de Itacajá, que vinha em ascensão desde a chegada dos primeiros moradores até a década de 1940, começa entrar em depressão. Com o massacre dos índios Krahós ocorrido em outubro de 1940, intervenção do Governo Federal, separação do território indígena, retirada dos fazendeiros e agricultores por intermédio do pastor Dodanim Gonçalves, sem a devida indenização em 1952, o município permanece em estado de recessão por longos anos.

Melatti (1967) menciona que "Por volta do ano de 1960 a situação econômica havia se acomodado; a forma rudimentar na criação de gado, produção agrícola e modais de transporte não colocava a cidade em condições de competitividade com cidades onde os acessos facilitavam o escoamento do excedente produzido."

Segundo Melatti (1967), o transporte da produção era feito a pé; por isso, os rebanhos eram muito maltratados pelas longas caminhadas até o destino, que eram os mais variados, como Pedro Afonso, Carolina/MA, Balsas/MA e até mesmo São Luís e Belém, capitais do Maranhão e Pará, respectivamente. A produção agrícola que, às vezes, mal dava para o consumo interno, quando existia excedente, era escoada por pequenas embarcações na época das cheias do rio, período em que era possível a navegação, sobre os ombros dos trabalhadores, tropas de muares e juntas de bois de carro.

Na região, até esse período, não existiam escolas formais para a alfabetização. As pessoas recorriam às das fazendas, normalmente com paredes feitas de palha, quando melhor, adobe com cobertura sempre de palha, chão batido e assentos em toras ou travessões de madeira e tamboretes rústicos. Também buscavam alfabetização na Escola Evangélica Batista, que ficava junto a um orfanato.

A precariedade se estendia da situação financeira das famílias à educação e à saúde, pois não tinham hospitais e muito menos médicos. Quando algum enfermo grave, que possuía recursos financeiros, adoecia, recorria a Pedro Afonso ou Carolina/MA e, se houvesse necessidade, os mais abastados iam de avião, saindo de Pedro Afonso para Goiânia, capital do estado.

No fim dos anos 60 e meados de 70, a região norte goiana passou por profundas transformações, dentre as quais podemos mencionar as cidades de Araguaína, Gurupi, Porto Nacional e Pedro 
Afonso. Nas cidades retro mencionadas houve os mais variados impactos, numas perdas de população e redução do poder econômico, noutras o oposto ocorreu. Entretanto houve cidades como Itacajá cuja estrutura econômica pouco se alterou. O período apresentado é o mesmo que compreende a construção da rodovia BR-153.

Fazendo referência a Itacajá, Melatti declara que: A abertura da estrada Transbrasiliana contribuiu para facilitar o transporte de gado para o seu principal mercado - a capital paraense - mas não parece ter trazido nenhuma contribuição para as relações de produção (MELATTI, 1967).

Mesmo que a construção da BR-153 não tenha provocado impactos que causassem grandes transformações a Itacajá, que fica a 96 km de distância desta rodovia, com necessidade de balsa na travessia do rio Tocantins para alcançá-la, ou volta de $140 \mathrm{~km}$ por Pedro Afonso, com travessia do rio sobre ponte, ela não deixou de ser mais um dos meios para o escoamento da produção.

Com a construção da BR-153, foram melhoradas as rodovias com serviços de terraplanagem TO239 saindo de Itacajá e chegando a Guaraí/TO, às margens da BR-153 e BR-010, nos sentidos Santa Maria e Goiatins.

Em se tratando da atividade econômica, outras mudanças ocorreram em Itacajá; no período de 1960 a meados de 1975, o êxodo rural obrigou os criadores de gado a cercarem suas terras e formarem pastagens mais densas para seus rebanhos; foi construída uma ponte para travessia sobre o rio Manoel Alves Pequeno, que anteriormente era feita a vau, canoa ou a nado; foram construídas escolas de ensino médio; melhorias nas estruturas do comércio varejista; um hospital particular e um posto de saúde público.

A partir dos anos 80, foi implantado o sistema de iluminação pública permanente provinda de usina hidroelétrica, que outrora era feita através de motor a diesel por determinado período do dia; uma indústria de cerâmica automatizada, que anteriormente funcionava artesanalmente; hospital público e implantados sistemas de telefonia fixa, móvel e banda larga.

Atualmente, além desses recursos geradores de emprego e renda, Itacajá ainda continua com a criação de gado em pequena escala, agricultura melhorada com o tratamento do solo, empregos públicos na prefeitura e órgãos representativos do estado, aposentadorias e recursos do governo federal destinados aos índios Khraôs, os quais habitam a região. Com a pouca melhoria e ajuda do 
governo, a cidade foi pavimentada; aumentou-se o número de comércios, mas as rodovias que por elas passam, permanecem como leito natural até os dias atuais.

De acordo com a SEPLAN-TO (2014), o PIB itacajaense no estado, em 2010, ocupa a 47ª posição no ranking; a maior participação deste vem de serviços, com 52,4\%, seguido pela agropecuária com $38 \%$ e indústria com $9,6 \%$. O município ocupa a $44^{a}$ posição em números populacionais, com o $99^{\circ}$ PIB per capita e IDH-M na 100 posição, dos 139 municípios de seu estado. Quanto ao IDHM a maior participação vem da Longevidade com $43 \%$, seguida da Renda com $31 \%$ e Educação com $26 \%$.

Ao contrário da sucinta abordagem feita sobre as cidades de Gurupi, Porto Nacional, Pedro Afonso e Itacajá, Araguaína, por ser a cidade objeto deste estudo, concomitantemente à abertura da BR153, mereceu uma análise mais detalhada de seu status socioeconômico antes e depois da construção da referida rodovia. Não obstante, cabe ressaltar que, juntamente com Araguaína, o status socioeconômico e populacional das cidades correlatas estará, também, sendo apresentado, fazendo com que repetições de dados sejam evitadas.

\subsubsection{Araguaína - Aspectos históricos}

As cidades brasileiras de Maringá - PR, Brasília - DF e Palmas - TO surgiram a partir de um plano urbanístico desenvolvido por empresas privadas, ao contrário do que ocorreu com Araguaína, surgida por um aglomerado de pessoas desordenadamente às margens de uma rodovia. Ressalta-se a modernidade daqueles projetos de planejamento urbano, onde há representações simbólicas que enfatizam as suas imagens, destacando um polo econômico regional que se cria em uma região sem ocupação urbana anterior, conforme afirmam Andrade e Cordovil (2008).

Igualmente a um grande número de cidades brasileiras, Araguaína foi criada a partir de um povoado antecedido por duas famílias, que por duas vezes mudou de nome, até se tornar a cidade que hoje está bem constituída. Formada no limite sul de uma mancha florestal sobre o espigão TocantinsAraguaia (VALVERDE e DIAS, 1967), às margens de dois importantes rios, Andorinhas e Lontra, fundamentais para o abastecimento de água e energia elétrica para seus moradores e rebanhos.

A região de ricas terras onde está situado o município de Araguaína era ocupada pelos primeiros habitantes da região, os índios Carajás (DIAS e BRITO, 2012). Inicialmente, por volta de 1876, o 
município foi chamado de Lontra por localizar-se às margens do rio de mesmo nome. Devido a grandes conflitos com os índios Carajás. Sua denominação mudou para "Livre-nos Deus", nome que expressava o temor permanente não só do ataque dos Carajás, mas, também, dos animais selvagens que habitavam a primitiva região (RIBEIRO ET AL, 2013).

Para a sobrevivência do povoado, iniciou-se um pequeno cultivo de cereais num padrão de agricultura de subsistência e o excedente da produção era levado para ser vendido no Povoado Coco, atual Babaçulândia. Objetivando a melhoria econômica, adotaram a cultura do café, todavia, sem sucesso, devido às inúmeras dificuldades encontradas para escoamento da produção. Apesar da existência do meio de transporte fluvial, este não dava acesso às localidades de maior interesse pelo produto (RIBEIRO ET AL, 2013).

De acordo com Ribeiro (2013), em razão do isolamento imposto pela ausência de estradas, condições geográficas e insalubridade do clima, o povoado passou por um longo período de estagnação que durou até o ano de 1925, ano em que o povoado tomou um novo impulso com a chegada de novas famílias. Anos mais tarde, na casa de um morador, iniciou-se a alfabetização. Em 1936 chegou o primeiro destacamento policial.

Embora existissem os estradões feitos pelos habitantes da região, e por muares, havia a necessidade de estrada terrestre em condições satisfatórias para o escoamento da produção do local. Devido à falta de recursos de transporte e das longas distâncias, apesar dos anos de existência do povoado, Araguaína muito pouco cresceu a partir de seus primeiros moradores. Em depoimento feito por um antigo morador, apelidado por "Gaucho", em 1944, este disse que o local possuía seis casas e era denominado de Lontra (VALVERDE e DIAS, 1967).

Na Figura 4.3 pode ser observado como era o povoado Lontra pouco antes de se tornar a cidade de Araguaína. A retrata a cidade de Araguaína logo após a sua emancipação e início da abertura da rodovia federal BR-153, na década de 50, mas a data precisa não foi possível identificar.

São Vicente, atualmente Araguatins, foi o primeiro município a quem o povoado de Lontra pertencera, posteriormente a Boa Vista do Tocantins, hoje Tocantinópolis e por último a Filadélfia. Após emancipação de Filadélfia, no ano de 1948, o Povoado Lontra foi anexado a ela, ficando conhecida então, como Povoado de Araguaína. Cinco anos mais tarde o Povoado Araguaína, por 
Lei Municipal de Filadélfia em 1953, foi transformado em distrito, mantendo a mesma denominação. Finalmente, através de Lei Estadual em 14-11-1958, tornou-se cidade Araguaína, IBGE (2014).

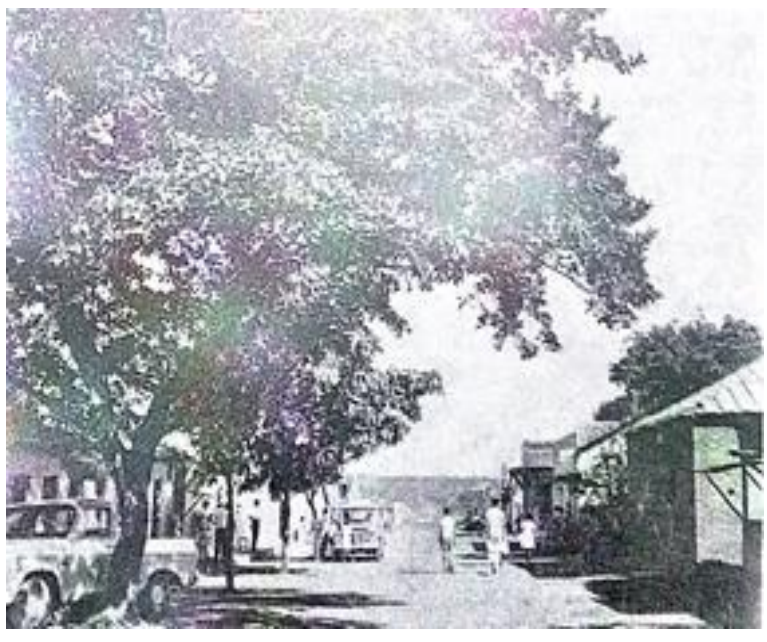

Figura 4.2: Avenida principal de Araguaína 195 ?

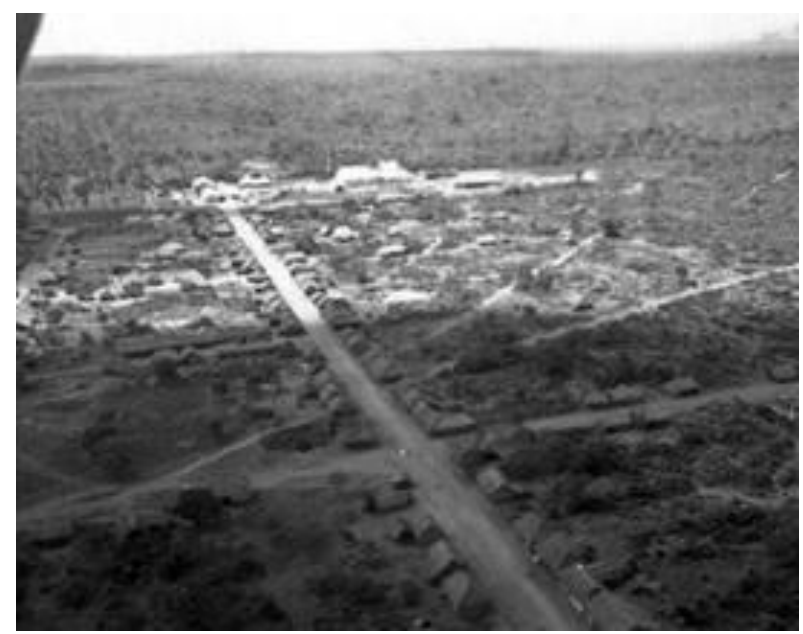

Figura 4.3: Vista aérea de Araguaína 195? Fonte: IBGE (2014) Fonte: IBGE (2014)

No período de 1960 a 1975, Araguaína atingiu um estágio de crescimento sem precedentes na história do Estado de Goiás, sendo que, em 1965, foi criada a indústria da Região Norte, Companhia Industrial e Mercantil da Bacia Amazônica (CIMBA). Em 1967 foi criado o primeiro frigorífico de Araguaína, de propriedade do Grupo Boa Sorte, que até hoje é um dos maiores da região com capacidade de abate de 900 cabeças de gado vacum por dia. Tal desenvolvimento tem repercutido de forma a ultrapassar as fronteiras do estado e do país, chamando atenção, inclusive, do exterior (RIBEIRO ET AL, 2013).

Em curto espaço de tempo, o município passou por profundas transformações, a ponto de, deixar de ser uma pequena cidade influenciada para ser influenciadora de outras cidades em aspectos econômicos e sociais, uma Capital Regional ${ }^{5}$ C (Figura 4.4), tanto dando suporte e subsídios econômicos, como fazendo intermediação de cidades menores de seu entorno, dos estados TO,

\footnotetext{
${ }^{5}$ Capital Regional - integram a este nível 70 centros que, como as metrópoles, também se relacionam com o estrato superior da rede urbana. Com capacidade de gestão no nível imediatamente inferior ao das metrópoles, têm área de influência de âmbito regional, sendo referidas como destino, para um conjunto de atividades, por grande número de municípios. Como o anterior, este nível também tem três subdivisões. O primeiro inclui as capitais estaduais não classificados no nível metropolitano e Campinas. O Segundo e o terceiro além da diferenciação de porte, têm padrão de localização regionalizado com o segundo mais presente no centro-sul e o terceiro nas demais regiões do País. IBGE.
} 
MA, e PA, com a capital Palmas e grandes centros econômicos como Goiânia/GO, Brasília/DF, São Paulo/SP, Belém/PA e São Luís/MA.

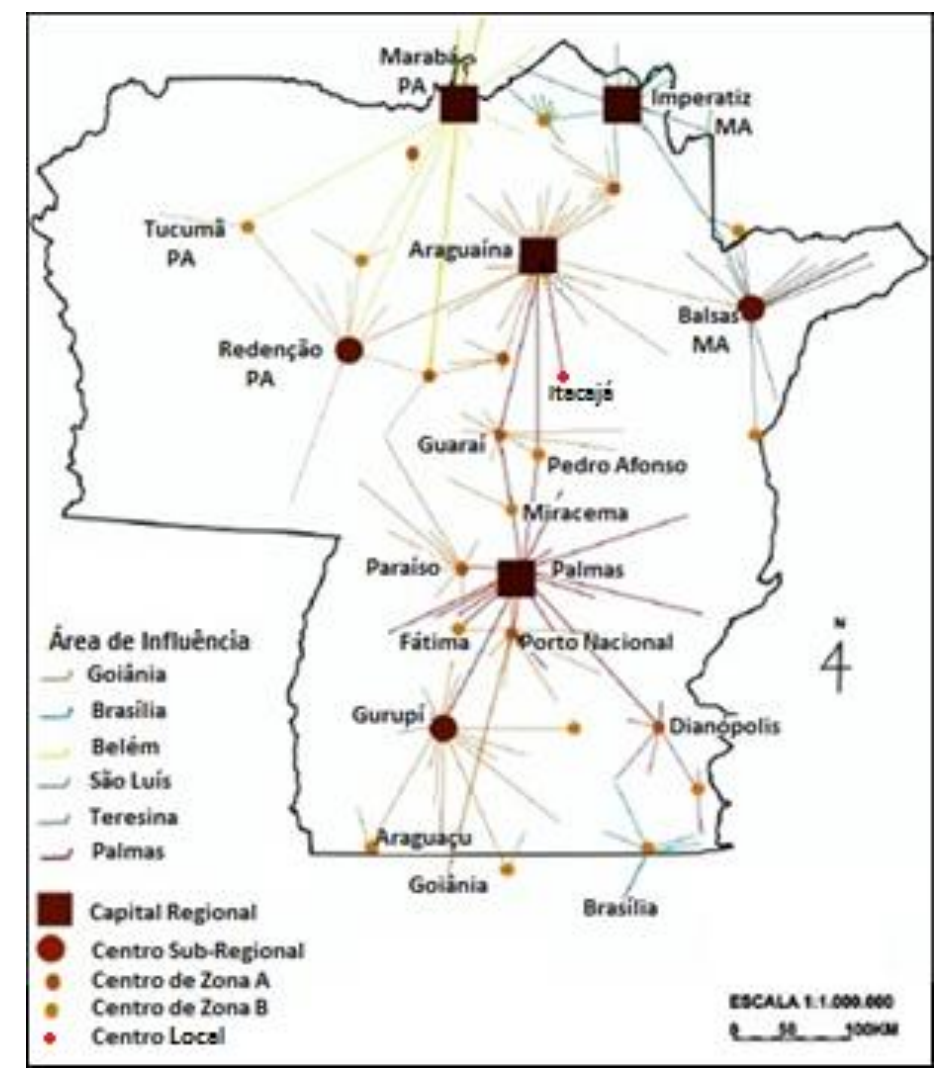

Figura 4.4: Araguaína, Capital Regional tipo C. Influência e intermediação com pequenos centros locais, capitais regionais e metrópoles.

Fonte: IBGE, (2014, adaptado pelo autor)

As transformações ocorridas em Araguaína não deixaram, no entanto, de provocar mudanças no aspecto urbano. Dias e Brito (2012), destacam que:

A rodovia provocou uma reorganização da rede urbana no Norte Goiano, perdendo em importância as cidades ribeirinhas em favor das cidades surgidas e reestruturadas às margens da nova BR. Araguaína emerge nesse contexto e se transforma em um grande pólo de crescimento. Hoje sua territorialidade é construída baseada em territórios-redes, e a rodovia Belém-Brasília é uma das bases dessa territorialização.

Conforme Ribeiro et Al (2013) apesar de Araguaína ter apresentado uma evolução econômica em 1926. Com a chegada de novas famílias no então povoado Lontra, o processo de desenvolvimento socioeconômico do município iniciou-se, na realidade, a partir de 1960 com a construção da Transbrasiliana, o que fez com que a cidade crescesse exorbitantemente em relação às demais 
cidades próximas, as quais eram maiores e mais antigas do que ela, chegando a ser a quarta maior cidade do então estado de Goiás, menor apenas para Luziânia, Anápolis e Goiânia, no período de 1980 a 1986.

Com a criação do estado do Tocantins em 1989, Araguaína tornou-se a maior cidade do novo estado.

O município de Araguaína localiza-se nas coordenadas $07^{\circ} .11^{\prime} 28^{\prime \prime}$ sul, 48¹2’26” oeste, ao norte do estado do Tocantins, na microrregião "Araguaína". Com área compreendida de 3.920 km², limita-se com os seguintes municípios: Aragominas, Babaçulândia, Carmolândia, Filadélfia, Muricilândia, Nova Olinda, Palmeirante, Pau d'Arco, Piraquê, Santa Fé do Araguaia e Wanderlândia, todos estes no próprio estado do Tocantins e ainda, com o município de Floresta do Araguaia, no estado do Pará, tendo o rio Araguaia como divisa entre os estados.

Para compor a microrregião de Araguaína, além dos 11 municípios tocantinenses que fazem limites com o município de Araguaína, incluem-se ainda os municípios, Araguanã, Arapoema, Bandeirantes do Tocantins, Colinas do Tocantins, Palmeirante e Xambioá.

\subsubsection{Aspectos das rodovias no município de Araguaína e dos transportes em Araguaína e cidades correlatas.}

No sentido norte-sul, o principal acesso ao município é por meio da rodovia federal Transbrasiliana, BR-153, no sentido leste-oeste, pela rodovia estadual TO-222 e, ao lado perpendicular, a TO-164. Embora a TO-222 possua a maior extensão dentro do município, a BR-153 é a principal e mais importante via de acesso à Araguaína, conforme DNIT (2011).

As rodovias estaduais TO-222, TO-164, TO-424, TO-230, TO-226 (Figura 4.5) são conectadas à rodovia Transbrasiliana e juntas fazem a circulação entre Araguaína, sua região e fora dela, inclusive, facilitando o escoamento da produção agropecuária regional, levando às cidades brasileiras o fomento da exportação via porto maranhense.

A distância rodoviária dos grandes centros, com os quais o município de Araguaína possui relativa interação, devido ao eixo rodoviário, é: Goiânia-GO a 1.144 km, Brasília-DF a 1.128 km, BelémPA a 841 km, São Luís - MA a 842 km e Palmas -TO a 384 km, que, embora não esteja no eixo rodoviário, é a capital do estado de onde provêm todos os recursos do governo estadual. 
Nesse processo interno, observa-se a importância da TO-222 que atravessa Araguaína de leste a oeste e que tem o nome nesse trecho interno como avenida Bernardo Sayão, onde o comércio local foca-se, principalmente, na prestação de serviços e produtos para a área agroindustrial (Figura 4.5).

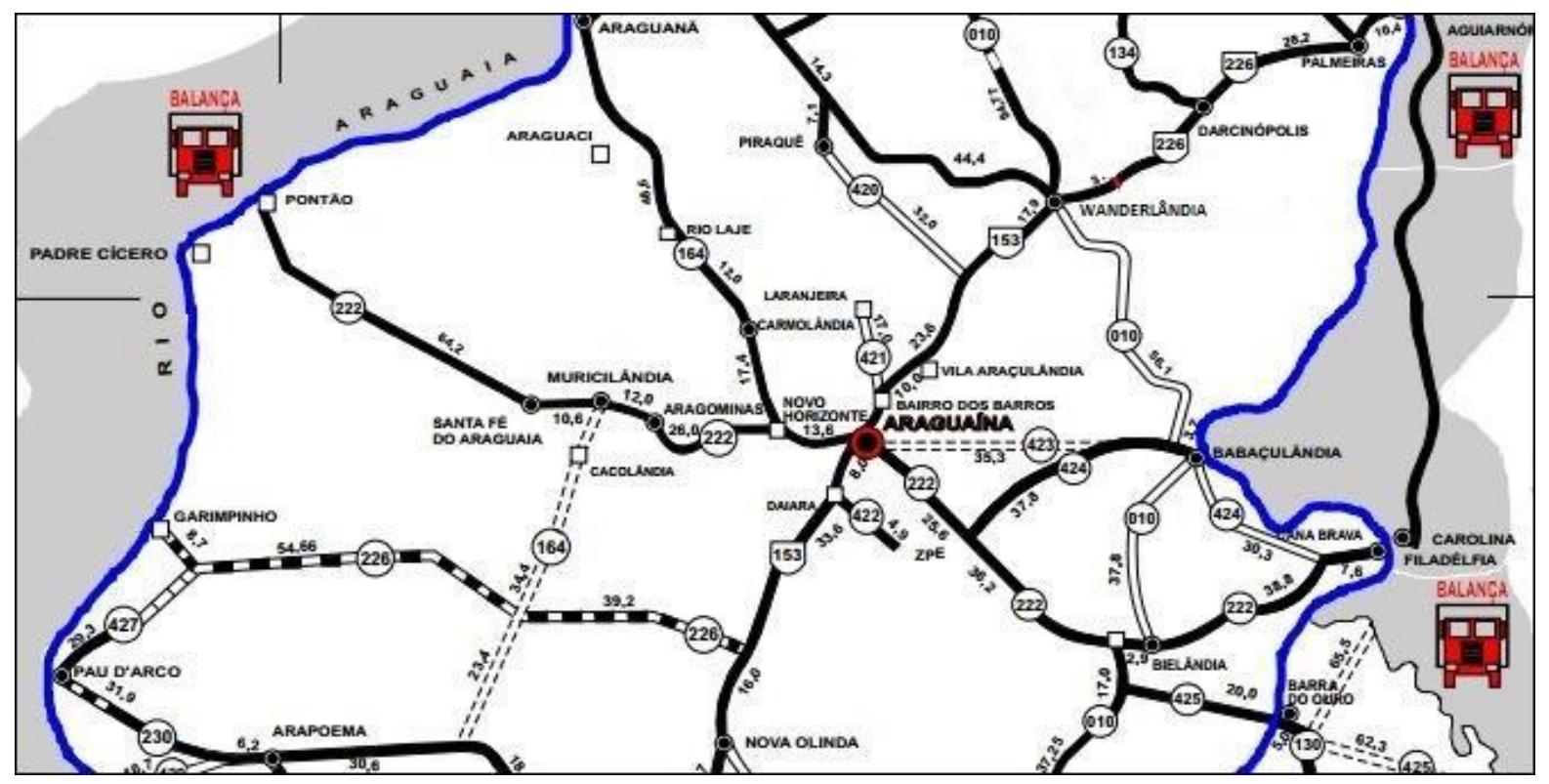

Figura 4.5: Aspectos da infraestrutura rodoviária da região de Araguaína (TO) Fonte: Transportes (2014, adaptado pelo autor)

Às margens da rodovia BR-153, nas proximidades da TO-222 desenvolveram-se grandes, médias e pequenas fazendas e intensa atividade no agronegócio, que impulsiona a economia do município. Com isso, criou-se o Distrito Agroindustrial de Araguaína (DAIARA), o qual possui diversas indústrias e quatro grandes frigoríficos de referência nacional, beneficiando tanto a produção de matéria prima como a produção de carne e couro.

De acordo com o sítio eletrônico do Mercado Físico Rural - MFRural (2014) de Marília/SP, focado no agronegócio, a localização geográfica de Araguaína possibilitou sua integração com todas as regiões do país para circulação de pessoas e mercadorias por meio de transporte aéreo e terrestre. Além desses modais de transporte, o município foi alcançado pela Ferrovia Norte-Sul (EF-151) e também contemplado com um pátio multimodal, onde operam sete empresas com contrato de arrendamento para o transporte de commodities agrícolas, fertilizantes, combustíveis e containers com carga em geral, conforme VALEC (2014). 
Apesar de Araguaína ter sido alcançada pelo transporte ferroviário em 2007 e possuir um pátio multimodal para o embarque e desembarque de cargas, principalmente para o agronegócio regional, como exemplo, a soja, que vai até o porto de Itaqui, no Maranhão, e de lá para o mercado mundial, o transporte de carga, em quase sua totalidade, é realizado pelo transporte rodoviário, segundo VALEC (2014).

Infere-se que a razão de maior parte dos transportes de carga ser feita pelo meio rodoviário é devido ao fato de as rodovias estarem mais tempo em operação, maior alcance e interação com outras regiões e, somente em 2014, a EF-151, ter ultrapassado a fronteira do estado do Tocantins, chegando a Anápolis Goiás, totalizando 1.574 km de extensão. Com isso, só será possível mensurar os ganhos do transporte de carga feito pela EF-151 em relação as rodovias após períodos de avaliação.

Ainda sobre a FNS, o previsto é $4.733 \mathrm{~km}$ de extensão na sua conclusão, ligando Barcarena no estado do Pará, até o estado do Rio Grande do Sul que vai configura uma verdadeira espinha dorsal ferroviária, segundo VALEC (2014).

Apesar da existência de uma ferrovia com pátio multimodal para o transporte de carga nos municípios de Araguaína, Pedro Afonso, Porto Nacional e Gurupi, o modal ferroviário de carga não influencia nas avaliações do custo do transporte de carga e nem crescimento e desenvolvimento econômico de Araguaína no período da construção da rodovia Transbrasiliana, pois não tem o mesmo alcance da referida rodovia; ressalte-se que a ferrovia com pátio modal alcançou somente no ano de 2014 a cidade de Gurupi a qual foi utilizada nas comparações com Araguaína.

\subsubsection{Custo dos transportes de carga}

De acordo a Tabela 4.2, é possível afirmar, que, na medida em que as estradas de rodagens vão melhorando suas condições de uso, vai ocorrendo a redução do custo de transporte.

Tabela 4.2: Custo com transportes entre 1968 a 1995

\begin{tabular}{l|c|c|c}
\hline \multicolumn{1}{c|}{ Município } & 1968 & 1980 & 1995 \\
\hline Araguaína & $1.676,00$ & $1.259,48$ & 835,30 \\
Gurupi & 892,21 & 610,00 & 610,00 \\
Itacajá & $2.317,76$ & $1.867,25$ & $1.708,18$ \\
Pedro Afonso & $1.859,71$ & $1.247,00$ & $1.013,00$ \\
Porto Nacional & $1.269,71$ & 987,50 & 897,50 \\
\hline
\end{tabular}

Fonte: IPEA (2014, adaptado pelo autor) 
A Tabela 4.2 faz referência ao transporte rodoviário onde se verifica que todas as cidades apresentadas, após a finalização construção da rodovia Transbrasiliana (BR-153), tiveram uma redução nos custos dos transportes entre a cidade e a capital mais próxima, como por exemplo, Araguaína com redução de 33\% e Gurupi, 46\%. Das cidades que não estão às margens da Transbrasiliana, a que teve maior redução nos custos foi Pedro Afonso com 49\%, seguida por Porto Nacional com 29\%. A que teve a menor redução foi Itacajá com $24 \%$.

Convém lembrar que, apesar de Itacajá, Pedro Afonso e Porto Nacional não terem sido contempladas com acesso pavimentado no período estudado, o acesso a essas cidades foi melhorado com serviço de terraplanagem. Outro fator que contribuiu para a redução dos custos dos transportes destas cidades para a capital mais próxima foi o fato de que, para qualquer cidade acessar a capital mais próxima era necessário adentrar à BR-153, rodovia que estava pavimentada. Acrescenta-se, ainda, que Itacajá permanece ao leito natural até nos dias atuais.

Quanto ao transporte de carga por meio aéreo, apesar do aeroporto de Araguaína, denominado “Aeroporto Internacional de Araguaína", ser o principal aeroporto da região norte do estado do Tocantins e também de algumas localidades do sul dos estados do Pará e Maranhão e de ter capacidade para pouso e decolagem de aeronaves de grande porte, Araguaína não utiliza esta modalidade de transporte para carga, apenas para o transporte de passageiros, que tem crescido simultaneamente com as melhorias das condições financeiras e crescimento populacional.

\subsubsection{Dinâmica do crescimento populacional de Araguaína e cidades correlatas}

Segundo Valverde e Dias (1967), a ocupação tem nesta área todas as características de um povoamento recente e com casas em construção. Existe ainda um ou outro modesto núcleo de população diferenciado com traçado do tipo Strassendoorf ${ }^{6}$, um contraste para Araguaína, cidade muito espalhada, que conserva não apenas o modelo original de sua formação. Mesmo existindo ainda considerável parte da estrutura urbana para organizar, Araguaína já existia como cidade antes da abertura da estrada rodoviária BR-153.

Apesar do primeiro impacto no crescimento de Araguaína, na fase inicial, com trabalhadores vindos para a construção da rodovia, o grande impulso veio, porém, cinco anos após a abertura da

\footnotetext{
${ }^{6}$ Modelo de vila ou cidade com edificações feitas ao longo de uma estrada ou rua.
} 
rodovia, com afluxo de povoadores mineiros, goianos, paulistas, paranaenses, maranhenses, piauienses e nordestinos em geral (VALVERDE e DIAS, 1967).

De acordo com os números do IBGE (2010), 64\% dos 150 mil habitantes do município fazem parte da População Economicamente Ativa (PEA). O município de Araguaína possui densidade demográfica de 37,62 hab./ $/ \mathrm{km}^{2}$, acima, portanto, da densidade demográfica do estado do Tocantins (4,98 hab./km²) e do Brasil (22,46 hab./km²).

As maiores cidades do estado são respectivamente: Palmas, Araguaína, Gurupi, Porto Nacional e Paraíso do Tocantins. Juntas, estas cinco cidades abrigavam em 2009, cerca de $42 \%$ da população total do estado, (RIBEIRO ET Al, 2013).

Tabela 4.3: População de Araguaína e outras cidades do Tocantins 1940-2010

\begin{tabular}{l|c|c|c|c|c|c|c|c|c|c}
\hline \multicolumn{1}{c|}{ Município } & 1940 & 1950 & 1960 & 1970 & 1980 & 1991 & 1996 & 2000 & 2007 & 2010 \\
\hline Araguaína & & & 10.622 & 37.780 & 72.063 & 103.315 & 105.019 & 113.143 & 115.759 & 150.484 \\
Gurupi & & & 11.915 & 24.660 & 38.653 & 56.752 & 64.725 & 65.034 & 71.413 & 76.755 \\
Itacajá & & & 10.655 & 12.168 & 13.940 & 13.933 & 6.549 & 6.815 & 6.386 & 7.104 \\
Pedro Afonso & 31.226 & 38.84 & 9.607 & 10.455 & 10.021 & 13.432 & 8.648 & 9.028 & 10.294 & 11.539 \\
Porto Nacional & 20.794 & 42.23 & 22.872 & 31.517 & 39.327 & 43.224 & 43.365 & 44.991 & 45.289 & 49.146 \\
\hline
\end{tabular}

Fonte: IPEA (2014, adaptado pelo autor)

Ainda em 1950, Araguaína, Gurupi e Itacajá não passavam de pequenos povoados e não dispunham de censo demográfico por pertencerem a outros municípios onde seus sensos demográficos eram vinculados, enquanto que as cidades Porto Nacional, fundada em 1738 e Pedro Afonso em 1847, apresentam em 1950 população de 42.231 e 38.844 habitantes, respectivamente .

Em 1960, os povoados estavam emancipados e contavam com um número significativo de habitantes, acima inclusive da população de Pedro Afonso, que estava às vésperas de seu centenário, teve um decréscimo populacional de 24\%. Porto Nacional, nesta mesma década, embora não tenha ficado com população menor do que as novas cidades, teve uma baixa no número de habitantes em $75 \%$.

No senso demográfico IBGE (1970), Araguaína é apresentada com uma população superior a todas cidades demonstradas na Tabela 4.3, inclusive Porto Nacional que, em 1960, tinha uma população mais do que o dobro da população de Araguaína. Na escalada do crescimento populacional a seguir vem Gurupi, que por volta de 1980 faz interseção com Porto Nacional e ultrapassa-o. 
Observa-se no recrudescimento da população de Araguaína e Gurupi em relação às demais cidades, sempre em ascendência e sobressaltos desde a década de 60 . O mais recente foi nos fins dos anos 90, incorporação das referidas cidades ao estado do Tocantins.

Quanto às perdas populacionais ocorridas em Pedro Afonso e Porto Nacional ocorridas até 1960, além dos trabalhadores que emigraram para as cidades às margens da rodovia, elas justificam-se também pela emancipação das cidades distritais como Itacajá e Gurupi. A partir de 1960, cabe a avaliação das razões do crescimento exponencial de Araguaína e relação as demais cidades, inclusive Gurupi, que foi fundada no mesmo dia e ano e que também está às margens da BR-153.

Foi por volta da década de 50 e 60 que houve incentivo, por parte do governo, ao processo de ocupação de terras destinadas à produção da atividade agrícola e pecuária em grandes regiões do país, ainda pouco explorada como a região norte e centro-oeste. Para tal, a Superintendência de Desenvolvimento da Amazônia (SUDAM) foi criada no governo do presidente Humberto de Alencar Castelo Branco, com o objetivo de facilitar a aquisição de terras e fomentar o desenvolvimento da região com políticas de fortes incentivos financeiros, para buscar e atrair grandes investidores, conforme SUDAM (2015).

Desde a fundação de Araguaína, sua população dividiu-se entre urbana e rural, com destaque à zona rural que, entre os anos de 1960-1970 teve uma Taxa Geométrica de Crescimento Anual (TGCA) de 9,23\%, mas, a partir da década de 70, iniciou-se um grande declínio nessa população. Segundo Ribeiro, et al, (2013), a causa provável desse contraditório tenha sido devido ao processo de migração para a área urbana, apresentando uma TGCA negativa de -9,97\%, no intervalo entre 1991-2000, mantendo-se igual ou menor que 1,00\% nos demais períodos; assim, a população rural permaneceu estável desde o ano de 2000, conforme pode ser observado na (Tabela 4.4).

Tabela 4.4: Evolução populacional do município de Araguaína

\begin{tabular}{c|c|c|c|c|c|c|c|c|c|c}
\hline ANO & INTERVALOS & $\begin{array}{c}\text { POP. } \\
\text { TOTAL }\end{array}$ & $\begin{array}{c}\text { TCA } \\
(\%)\end{array}$ & $\begin{array}{c}\text { TGCA } \\
(\% \\
\mathbf{a} . \mathbf{\%})\end{array}$ & $\begin{array}{c}\text { POP- } \\
\text { URBANA }\end{array}$ & $\begin{array}{c}\text { TCA } \\
(\boldsymbol{\%})\end{array}$ & $\begin{array}{c}\text { TGCA } \\
(\boldsymbol{\%} \\
\mathbf{a . a .})\end{array}$ & $\begin{array}{c}\text { POP. } \\
\text { RURA } \\
\mathbf{L}\end{array}$ & $\begin{array}{c}\text { TCA } \\
(\%)\end{array}$ & $\begin{array}{c}\text { TGCA (\% } \\
\mathbf{a . a .})\end{array}$ \\
\hline 1960 & - & 10.826 & - & - & 2.382 & - & - & 8.444 & - & - \\
1970 & $1960 / 1970$ & 37.780 & 248,97 & 13,31 & 17.372 & 629,30 & 21,98 & 20.408 & 141,69 & 9,23 \\
1980 & $1970 / 1980$ & 72.063 & 90,74 & 6,67 & 47.956 & 176,05 & 10,69 & 24.107 & 18,13 & 1,68 \\
1991 & $1980 / 1991$ & 103.315 & 43,37 & 3,33 & 84.614 & 76,44 & 5,30 & 18.701 & $-22,43$ & $-2,28$ \\
2000 & $1991 / 2000$ & 113.143 & 9,51 & 1,01 & 105.874 & 25,13 & 2,52 & 7.269 & $-61,13$ & $-9,97$ \\
2010 & $2000 / 2010$ & 150.484 & 33,00 & 2,89 & 142.925 & 35,00 & 3,05 & 7.559 & 3,99 & 0,39 \\
\hline
\end{tabular}

Fonte: Censo demográfico 1960 a 2012, IBGE (2014, adaptado pelo autor) 
Segundo Farias e Almeida (2010), o processo de expansão de seu centro urbano passa por um longo período de estagnação, sob o ponto de vista da lógica do modo de produção capitalista. Somente no plano de metas do presidente Juscelino Kubitschek com a construção da BR-153, a cidade teve um novo estímulo para seu crescimento, tanto pela chegada de novos habitantes para trabalharem nas obras desta rodovia, como pela utilização da mão de obra local a serviço da mesma. É o que vem afirmar Becker:

A urbanização não é aí uma consequência da expansão agrícola: A fronteira já nasce urbana, tem um ritmo de urbanização mais rápido que no resto do país. Na década de 60 e 70 a maior parte do fluxo migratório era espontâneo, destinava-se ao norte e Goiás e sul do Pará, e era formado por trabalhadores rurais pequenos ocupantes, posseiros e proprietários sem capital vindo do nordeste" (BECKER, 1991).

No período de 1991 a 2010, a população de Araguaína teve uma taxa média de crescimento anual de 2,89\%. No Estado, estas taxas foram de 1,02\% entre 2000 e 2010, e 1,03\% entre 1991 e 2000. No país foram de 1,01\% entre 2000 e 2010 e 1,02\% entre 1991 e 2000. Nas últimas duas décadas, a taxa de urbanização cresceu 42,01\% (PNUD, 2010). Verifica-se que a alta TGCA na década de 2000/2010 em Araguaína de 2,89\%, deve-se, principalmente, a estes últimos quatro anos de 2007 a 2010.

O período mais importante a ser observado, tanto em relação ao crescimento populacional quanto ao da Taxa Geométrica de Crescimento Anual da População (TGCA) em Araguaína é análogo ao período da construção da Rodovia Transbrasiliana, entre os anos de 1960 e 1970/1975, em que é possível constatar que houve um maior incremento no volume de pessoas.

A dinâmica do elevado crescimento populacional para as cidades de Araguaína e Gurupi, com percentual muito maior para Araguaína, no período da construção da rodovia Transbrasiliana, devese às atividades econômicas desenvolvidas com a construção da referenciada rodovia e, consequentemente, pela descoberta de uma nova fronteira agrícola capaz de fomentar excedente às demandas internas e externas aos referenciados municípios (SUDAM, 2015) e (FARIAS ET AL, 2010).

Cabe, ainda, ressaltar que os dados relacionados ao crescimento populacional, aspectos rodoviários, transportes, históricos e geográficos das cidades Gurupi, Porto Nacional, Pedro Afonso, Itacajá e Araguaína darão subsídios às investigações feitas relacionadas ao crescimento 
econômico apresentado pelo PIB e ao desenvolvimento econômico apresentado pelo IDH das cidades relacionadas, tendo como referência a rodovia Transbrasiliana, promotora dos eventos econômicos em Araguaína expostos neste trabalho. 


\section{ASPECTOS DO CRESCIMENTO ECONÔMICO E DESENVOLVIMENTO ECONÔMICO DE ARAGUAÍNA E CIDADES CORRELATAS}

A economia do município de Araguaína, originalmente, baseava-se principalmente na produção de babaçu, e secundariamente, na produção do arroz, amendoim e algodão. Como elemento, que também pertencera à atividade econômica, utilizou-se também a madeira mogno ricamente existentes às margens do rio Araguaia. Como atividade econômica da região, especialmente dos lavradores, usava-se a prática de caça de animais silvestres como o caititu, veado e lontra para a extração e venda do couro para atravessadores de Anápolis, os quais, por sua vez, vendiam-no para os grandes mercados do Sudeste (VALVERDE e DIAS, 1967).

A partir de 1960, com a construção da BR-153, Araguaína passou a ser um importante entreposto no extremo norte do então Estado de Goiás, devido à sua localização geográfica, e transformou-se num importante elo entre Norte/Nordeste (RIBEIRO ET AL, 2013). Com isso, começou a alcançar notoriedade econômica na região, tendo como fatores desencadeadores do crescimento econômico a expansão das atividades agropecuária, indústria, comércio e serviços.

\subsection{ASPECTOS DO CRESCIMENTO ECONÔMICO}

O crescimento econômico de Araguaína passou por radicais mudanças, ocorridas no cenário político após o golpe militar de 1964, a intervenção na Amazônia seguiu as diretrizes adotadas na década anterior. A ação do governo tinha por base o Plano de Valorização da Amazônia, elaborado em 1953, podendo ser comprovadas durante o processo que extinguiu a Superintendência do Plano de Valorização Econômica da Amazônia (SPVEA) e criou a SUDAM, que incorporou e reproduziu as concepções anteriores para a colonização da região, conforme pode-se observar no artigo $4^{\circ}$ da lei de criação da SUDAM, onde se lê o seguinte:

[...] b) definição dos espaços econômicos suscetíveis de desenvolvimento planejado, com a fixação de pólos de crescimento capazes de induzir o desenvolvimento de áreas vizinhas; [...] e) adoção de política imigratória para a Região, com aproveitamento de excedentes populacionais internos e contingentes selecionados externos. 
Para o crescimento econômico na época priorizava-se a criação e a consolidação de Polos. Esta mesorregião goiana vivenciou os impactos do POLOCENTRO $^{7}$ e POLOAMAZÔNIA $^{8}$. Como as estratégias inovadoras foram omitidas no contexto do intercâmbio com os arranjos locais, a intensificação do êxodo rural e a concentração fundiária foram inevitáveis.

Atualmente Araguaína possui várias indústrias, com destaque para a de laticínios, e conta com uma grande zona de influência econômica que envolve os estados do Maranhão e Pará e parte significativa do Tocantins (Figura 5.1).

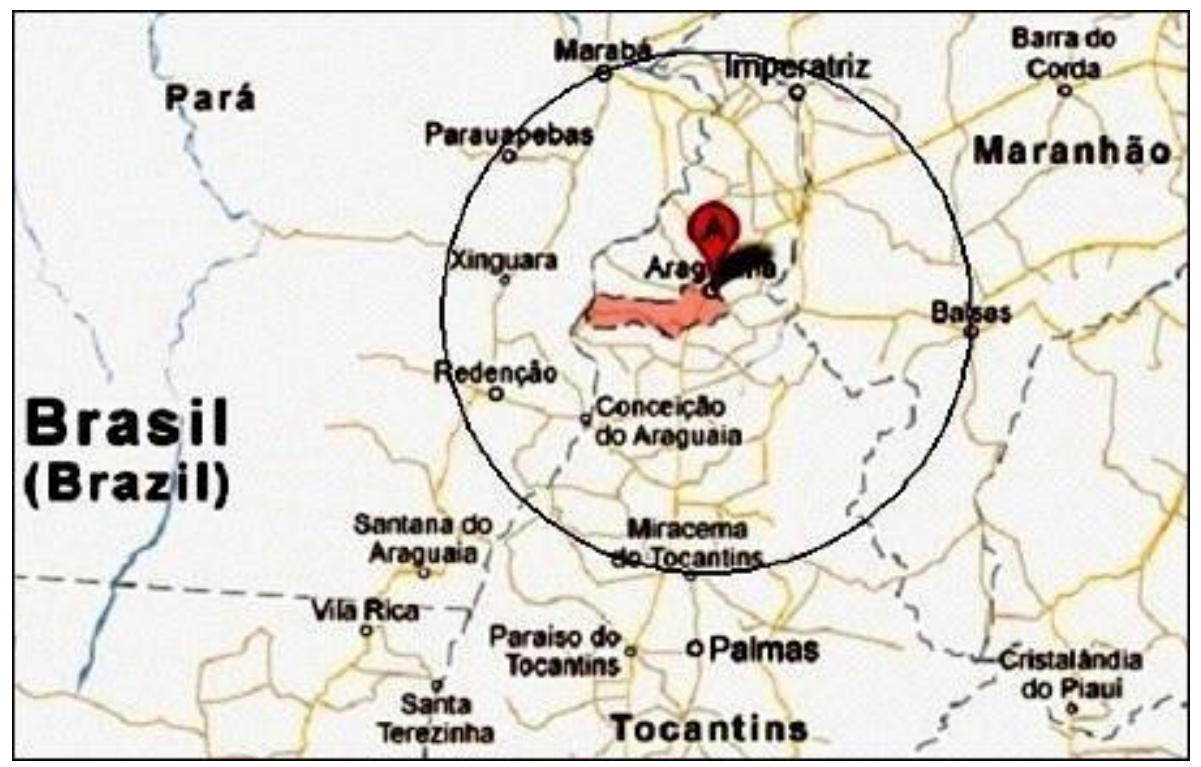

Figura 5.1: Raio de Influência do município de Araguaína

Fonte: Googlemaps (2014, adaptado pelo autor)

Em 2007 o IBGE realizou um levantamento de dados sobre a hierarquia urbana no Brasil e considerou que o estado do Tocantins não possui cidades com nível de metrópole, possuindo apenas duas capitais regionais: Palmas, de médio porte do tipo B e Araguaína, de menor porte do tipo $\mathrm{C}^{9}$. Araguaína é, portanto, a segunda cidade mais influente do Tocantins e recebe a mesma

\footnotetext{
${ }^{7}$ Programa de Desenvolvimento dos Cerrados, para a criação de polos de desenvolvimento do cerrado e ocupação do Planalto Central Brasileiro. Criado pelo Decreto Lei $\mathrm{n}^{\circ}$ 75.320, de 24 de janeiro de 1975.

${ }^{8}$ Programa de Pólos Agropecuários e Agrominerais da Amazônia, cujo a finalidade de promover o aproveitamento integrado das potencialidades agropecuárias, agro-industriais, florestais e minerais, em áreas prioritárias da Amazônia. Criado pelo Decreto ${ }^{\circ}$ 74.607, de 24 de setembro de 1974.

${ }^{9}$ Capital Regional é uma hierarquia urbana que, de acordo com o porte da cidade, condições socioeconômico, populacional, capacidade de influência e gestão a um nível hierárquico imediatamente inferior, articulação urbana como cidade intermediária entre cidades imediatamente maiores e menores, que a partir de uma Metrópole como Goiânia, poderá ser classificada como Capital Regional A, B ou C, Centro Sub Regional A ou B, Centro de Zona A ou $\mathrm{B}$ e por último, Centro Local, que não exercer influência a qualquer outra cidade, restringindo-se às influências das cidades maiores, como Itacajá.
} 
classificação de importância das cidades próximas: Marabá e Imperatriz, nos estados do Pará e Maranhão, respectivamente, sobre as quais Araguaína exerce influência econômica (Figura 5.2).

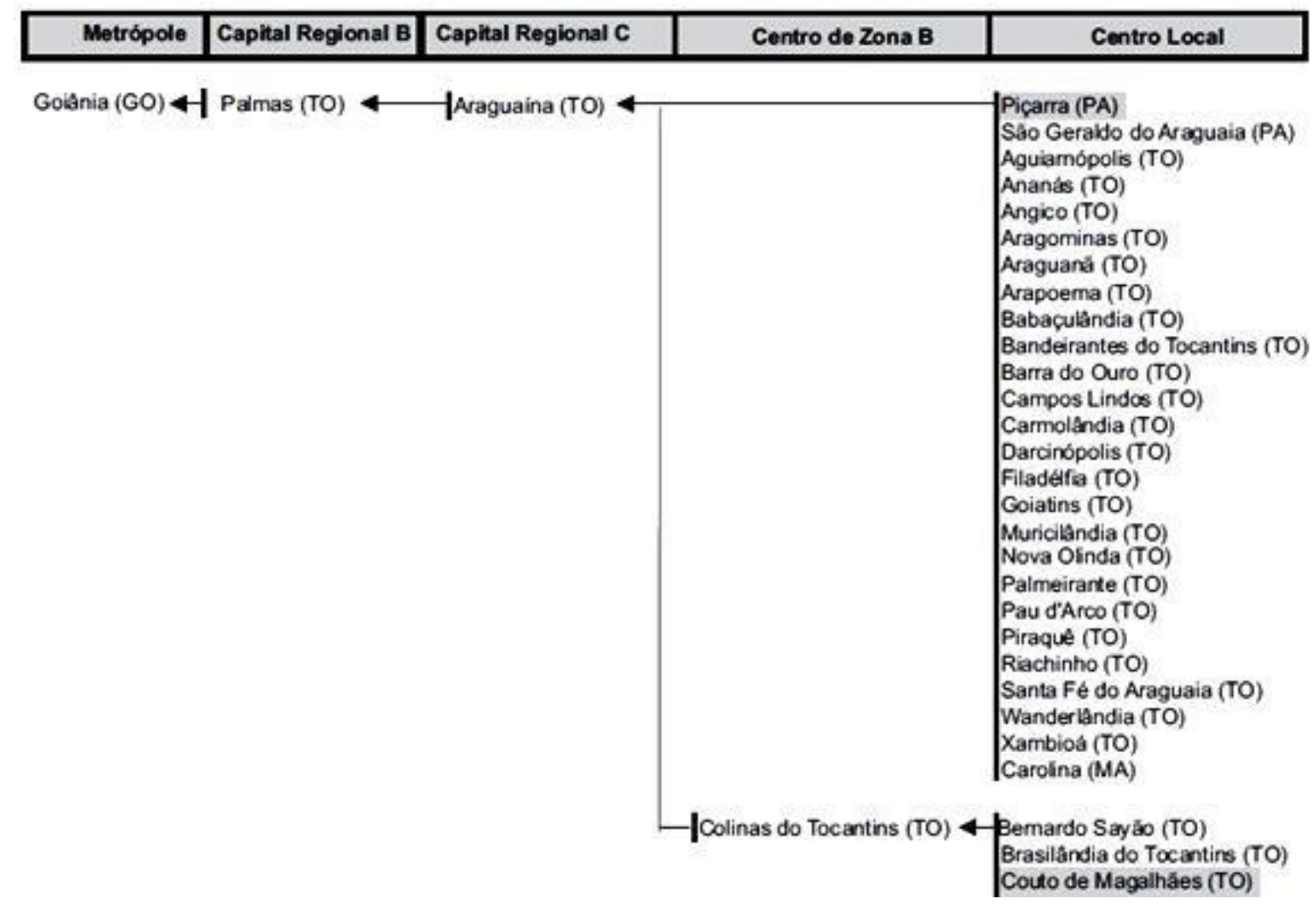

Figura 5.2: Cidades com as quais Araguaína exerce influência e mantém relacionamento Fonte: IBGE (2007, adaptado pelo autor)

Segundo o mesmo estudo, Araguaína, através de Palmas, faz parte da região de influência da Metrópole Regional Goiânia e não Brasília, apesar de ambas estarem praticamente à mesma distância, cerca de $1.200 \mathrm{~km}$. Araguaína é a $15^{\mathrm{a}}$ maior cidade de relacionamento empresarial com Goiânia. No mesmo quesito, Palmas ocupa o $7^{\circ}$ lugar.

De acordo com Ribeiro et al (2013), na base econômica de Araguaína, devido ao crescimento da cidade, tem se destacado o mercado imobiliário, impulsionado pelos incentivos habitacionais do Governo Federal com os programas habitacionais como Minha Casa Minha Vida. O mercado imobiliário, juntamente com as Instituições de Ensino Superior (IES) que nos últimos anos foram instaladas, tem incentivado o mercado da construção civil, fator que tem contribuído consideravelmente para o aquecimento da economia da cidade. 
Os novos empreendimentos estão distribuídos nas regiões periféricas da cidade, situados nas proximidades do eixo da BR-153 e da represa do Rio Lontra, onde foi construída uma nova ponte interligando o centro da cidade às novas áreas de expansão (RIBEIRO ET AL, 2013).

\subsubsection{Agropecuária}

Onde se inicia a ocupação humana, para sobrevivência, quase sempre se principia a agropecuária. Até meados dos anos de 1950, em Araguaína, ainda se praticava a agricultura e a pecuária de subsistência, com poucas terras ocupadas, em 1960 a produção agropecuária apresentava 38.677 hectares (ha) ${ }^{10}$ de terras usadas, caracterizando assim produção em larga escala; em 1970 apresenta um astronômico incremento no uso da terra nove vezes maior, seguido de $85 \%$ em 1975 e $40 \%$ em 1980 (Figura 5.3).

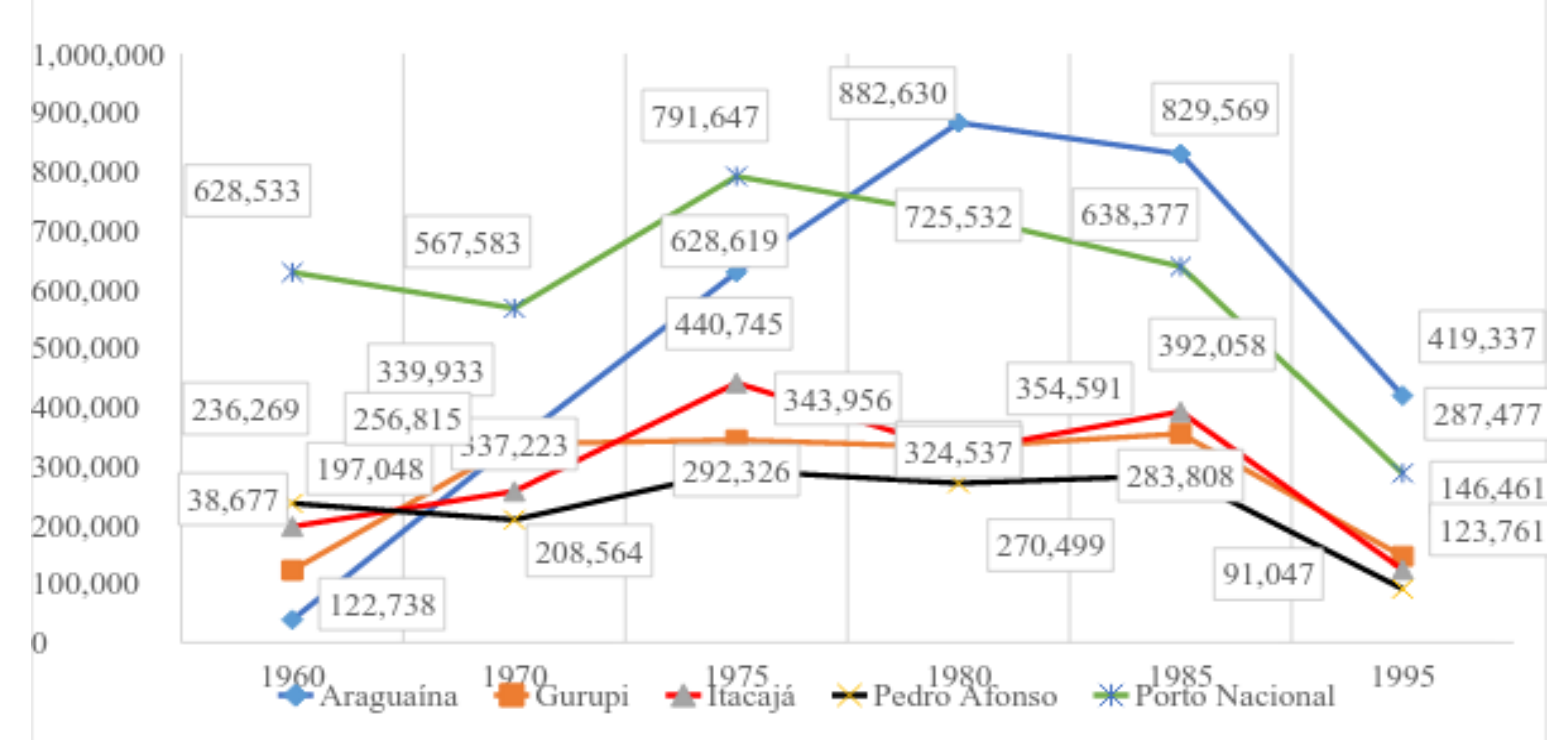

Figura 5.3: Uso da terra para fins agropecuários

Fonte: Fonte: IPEA (2014, adaptado pelo autor)

Se relacionarmos o crescimento do uso da terra para fins agropecuários em Araguaína e Gurupi, que foi 9 e 1,5 maior, respectivamente ao período da construção da rodovia e, consequentemente, ao aumento populacional e compará-los com as outras cidades aqui expostas, não contempladas com rodovia pavimentada, no período de 1960 a 1970, como Pedro Afonso, Porto Nacional e Itacajá, verifica-se que Pedro Afonso e Porto Nacional decresceram 12\% e 10\% e observa-se ainda

10 O hectare (ha) é utilizado para exprimir medidas de áreas agrárias de superfície, no entanto está fora do Sistema Internacional de Unidades de Medida (SI). 1 (um) hectare corresponde a $10.000 \mathrm{~m}^{2}$ (INMETRO, 2013) 
Itacajá, que apesar de não ter sido contemplada com rodovia como a BR-153 e nem tenha rio em condições de navegabilidade, foi pouco menos afetada que as demais cidades na sua produção agropecuária (Figura 5.3).

Complementando os dados do uso da terra para fins agropecuários, também foram pesquisados os dados do valor da produção do PIB agropecuária a preço básico multiplicado por mil reais do ano de 2000 a nível municipal, bem como foi possível constatar as diferenças existentes entre as cidades nos anos de 1960 e 1970, especialmente os que compreendem o período em que foi construída a rodovia Transbrasiliana (Tabela 5.1).

Através da Tabela 5.1 é possível constatar que o PIB municipal agropecuário de Araguaína em 1970, é superior em 5 vezes em relação ao valor constante em 1959. Mesmo mantendo um valor superior ao valor de Araguaína, Gurupi também teve ganho no valor agropecuário num percentual muito menor que a taxa de Araguaína, em 52\%. O oposto ocorre com as cidades de Itacajá que teve perda de valor em $27 \%$ e Pedro Afonso e Porto Nacional, ambas com perda de $42 \%$. Lembrando que o período apresentado compreende o mesmo período da construção da rodovia Transbrasiliana.

Tabela 5.1: PIB Municipal - agropecuária - valor adicionado - preços básicos

\begin{tabular}{l|c|c|c|c|c|c}
\hline \multicolumn{1}{c|}{ Município } & 1959 & 1970 & 1975 & 1985 & 1996 & 2001 \\
\hline Araguaína & $1.733,75$ & $8.460,47$ & $19.442,08$ & $85.909,85$ & $23.910,54$ & $26.983,75$ \\
Gurupi & $7.144,55$ & $10.882,32$ & $11.296,75$ & $21.548,73$ & $11.269,10$ & $9.067,04$ \\
Itacajá & $5.571,74$ & $4.065,52$ & $4.751,43$ & $9.059,90$ & $2.557,29$ & $4.099,88$ \\
Pedro Afonso & $5.006,75$ & $2.918,01$ & $3.378,74$ & $6.162,62$ & $6.424,21$ & $34.786,63$ \\
Porto Nacional & $14.580,41$ & $8.409,10$ & $16.347,84$ & $13.694,49$ & $11.282,63$ & $19.303,79$ \\
\hline
\end{tabular}

Fonte: IPEA (2014, adaptado pelo autor)

Ao apresentado na Tabela 5.1, mesmo que Araguaína tenha crescido em relação à agropecuária, em um percentual muito alto, se comparado as demais cidades, no período em que se conclui a construção da rodovia entre 1970 e 1975, há uma estabilidade e as cidades que tiveram perdas no período do início da construção da Rodovia Transbrasiliana voltam a crescer. Observa-se, também, que as cidades que tiveram perdas na economia, produzida pela agropecuária, no mesmo período de 1970 a 1975, e são exatamente as que estão fora do eixo da Transbrasiliana. 


\subsubsection{Indústria}

Conforme Senso Industrial de Goiás, IBGE (1960), Araguaína e Itacajá não dispunham de indústria; Gurupi, com a mesma idade de Araguaína, possuía apenas três estabelecimentos, enquanto que Porto Nacional e Pedro Afonso apresentavam doze e oito indústrias, respectivamente. No senso de 1970, Araguaína e Gurupi ultrapassam Porto Nacional e Pedro Afonso, sendo que Pedro Afonso teve redução no número de indústrias e Itacajá aparece com apenas três indústrias, número bem menor que o das demais cidades.

Nos sensos subsequentes, IBGE de 1975, 1980, 1985 as cidades de Araguaína, Gurupi e Porto Nacional mantém-se em constante crescimento e, entre 1985 a 1995, período que compreende a criação do estado do Tocantins. Gurupi cresce e ultrapassa Araguaína, que tinha o maior número de unidades industriais, num sobressalto de aproximadamente três vezes acima do número de unidades de Porto Nacional.

Nesse mesmo período, cai em 26\% o número de indústrias. Pedro Afonso e Itacajá, entre os anos de 1970 a 1995, mantém-se oscilando entre seis e três indústrias, respectivamente (Tabela 5.2).

Tabela 5.2: Crescimento do número de indústrias - Período 1960/1995

\begin{tabular}{l|c|c|c|c|c|c}
\hline \multicolumn{1}{c|}{ Município } & 1960 & 1970 & 1975 & 1980 & 1985 & 1995 \\
\hline Araguaína & 0 & 42 & 77 & 96 & 113 & 187 \\
Gurupi & 3 & 33 & 61 & 78 & 82 & 223 \\
Itacajá & 0 & 3 & 3 & 6 & 4 & 3 \\
Pedro Afonso & 8 & 6 & 4 & 4 & 5 & 6 \\
Porto Nacional & 12 & 25 & 97 & 50 & 94 & 70 \\
\hline
\end{tabular}

Fonte: Fonte: IBGE (2014, adaptado pelo autor)

Em contribuição ao número de unidades industriais foi levantado, também, o valor adicionado do PIB municipal da indústria a preço básico em reais do ano de 2000 (mil R\$), verificando-se que, embora, aparentemente exista divergência entre o crescimento do número de estabelecimentos industriais e a queda de valor do PIB da indústria entre 1970 e 1975, essa divergência ocorreu não pela existência real de incremento do valor adicionado, mas pela mudança do cálculo entre os anos de 1970 e 1996. Saliente-se que os elementos que compõe este setor compreendem: indústria de transformação e extrativa mineral, construção civil e serviços industriais de utilidade pública como energia elétrica e sistema de água e esgoto (IPEA, 2014). 
Tabela 5.3: Indústria - valor adicionado - preços básicos

\begin{tabular}{l|r|r|r|r|r|r}
\hline \multicolumn{1}{c|}{ Município } & $\mathbf{1 9 5 9}$ & \multicolumn{1}{c|}{$\mathbf{1 9 7 0}$} & \multicolumn{1}{c|}{$\mathbf{1 9 7 5}$} & \multicolumn{1}{c}{$\mathbf{1 9 8 5}$} & \multicolumn{1}{c}{$\mathbf{1 9 9 6}$} & \multicolumn{1}{c}{$\mathbf{2 0 0 1}$} \\
\hline Araguaína & & $8.998,47$ & $3.167,20$ & $19.744,06$ & $38.493,68$ & $119.734,92$ \\
Gurupi & 366,10 & $2.858,45$ & $2.260,27$ & $6.140,18$ & $64.023,76$ & $74.103,25$ \\
Itacajá & & 130,22 & 41,25 & 107,95 & 94,87 & $1.641,45$ \\
Pedro Afonso & 842,22 & 400,70 & 163,19 & 131,46 & 87,25 & $3.509,42$ \\
Porto Nacional & 329,14 & $3.545,93$ & $1.115,90$ & $2.263,95$ & $16.576,60$ & $33.065,99$ \\
\hline
\end{tabular}

Fonte: IPEA (2015, adaptado pelo autor)

Os dados expressos na Tabela 5.3 compreendem o valor adicionado a preço básico, multiplicado por mil reais, da indústria de transformação e extrativa mineral, construção civil e serviços industriais de utilidade pública, como usina hidroelétrica e fornecimento de rede de água e esgoto.

Com base nos referidos dados, constata-se que Gurupi, em 1959, apresenta três indústrias com valor adicionado de 366,10 multiplicado por mil reais. Já Araguaína, às margens da mesma rodovia - BR-153, fundada no mesmo dia e ano em que Gurupi foi fundada e Itacajá, que pertence a mesma década de fundação de Gurupi e Araguaína, não apresentam valor adicionado de indústria por não possuí-la. Pedro Afonso e Porto Nacional, sendo cidades mais antigas e tidas como centros econômicos regionais às margens do rio Tocantins, que ainda servia como via de transporte de passageiro e carga, apresentam, respectivamente, valor adicionado a preço básico de 842,22 e 329,14 em mil reais. Assim, é importante observar que Gurupi, neste mesmo ano, apresenta valor adicionado superior ao de Porto Nacional (Tabela 5.3).

Araguaína em 1970, dez anos após o início da construção da rodovia Transbrasiliana, apresenta-se com valor adicionado três vezes superior ao valor de Gurupi, superior inclusive ao valor adicionado das cidades de Porto Nacional, Pedro Afonso e Itacajá. Em 1975 apesar da redução do valor adicionado em função da alteração da estrutura do cálculo, IPEA (2014), Araguaína, mantém-se com valor adicionado em constante crescimento muito superior as demais cidades, acompanhado de sobressaltos nos anos subsequentes. Enquanto Gurupi e Porto Nacional também mantém em constante crescimento seu valor adicionado, ainda assim, apresentam valores menores que os de Araguaína. Quanto a Pedro Afonso e Itacajá, oscilam em decrescimento e crescimento nos anos subsequentes com baixo valor adicionado, se comparados as outras três cidades aqui apresentadas (Tabela 5.3). 


\subsubsection{Serviços}

Os setores econômicos do município de Araguaína demonstram-se desiguais e o setor de serviços concentra a maior parte dos recursos de sua economia. Mesmo com as desigualdades existentes, todos os setores, sem exceção, tiveram crescimento exponencial. Apesar de ter o cognome "Capital do Boi Gordo" pela expressão econômica e política representada pela pecuária, é o setor de serviço que concentra o maior volume de recursos econômicos do município.

Tal fato representa uma aparente contradição em relação ao cognome "cidade do boi gordo". Merece, portanto, maiores explicações. Primeiro há que se admitir que boa parte da indústria beneficia produtos de origem agropecuária, segundo, boa parte do comércio se destina a insumos primários, a máquinas e implementos agrícolas e pecuários (SILVA, 2012).

No senso de 1960 Araguaína apresenta apenas três unidades de serviços, mesma quantidade de Itacajá; Gurupi apresenta 19, Pedro Afonso e Porto Nacional apresentam 22 unidades de serviços. Em 1970, Araguaína cresce 43 vezes a mais, em relação ao ano de 1960, ficando acima de Itacajá 26 vezes e de Pedro Afonso em cinco vezes e de Porto Nacional em mais que o dobro; em relação a Gurupi, Araguaína cresceu apenas $4 \%$ a mais. Cinco anos mais tarde, quando se conclui a abertura da Transbrasiliana com pavimentação, há um incremento em Araguaína triplicado; as outras cidades tiveram crescimento menor: Gurupi 31\%, Itacajá 80\%, Pedro Afonso 31\% e Porto Nacional pouco mais que o dobro (Tabela 5.4).

É importante observar, também, que as unidades de serviços, entre os anos de 1975 a 1995, período da formação do estado do Tocantins, Araguaína, Itacajá, Pedro Afonso e Porto Nacional oscilam entre crescimento e decrescimento das unidades de serviços, tanto que Araguaína, em 1975, chegou a ter 394 unidades de serviços, muito acima das demais cidades, inclusive das unidades de serviços apresentadas em 1995 e termina com a mesma quantidade de unidades de serviço de Gurupi, única cidade que manteve seu crescimento constante desde o senso de 1960 (Tabela 5.4).

Tabela 5.4: Número total de Estabelecimentos ou Unidades Locais de Serviços

\begin{tabular}{l|c|c|c|c|c|c}
\hline \multicolumn{1}{c|}{ Município } & 1960 & 1970 & 1975 & 1980 & 1985 & 1995 \\
\hline Araguaína & 3 & 130 & 394 & 201 & 294 & 214 \\
Gurupi & 19 & 125 & 164 & 169 & 213 & 214 \\
Itacajá & 3 & 5 & 9 & 9 & 11 & 2 \\
Pedro Afonso & 22 & 26 & 34 & 9 & 5 & 10 \\
Porto Nacional & 22 & 61 & 142 & 99 & 152 & 75 \\
\hline
\end{tabular}

Fonte: IBGE (2014, adaptado pelo autor) 
Associado ao número de unidades de Serviços, que é composto por comércio, transporte e comunicação, intermediação financeira, administração pública, aluguéis e outros serviços está o valor adicionado deste setor do PIB municipal, a preço básico em reais do ano de 2000 (mil R\$). Com base na associação comparativa desses dois elementos, verificou-se que o número de estabelecimentos de unidades de serviços manteve-se em constante crescimento desde 1959 até 1985; o mesmo ocorreu com o valor adicionado para todas as cidades aqui analisadas, ultrapassando o período da construção da rodovia Transbrasiliana em mais de dez anos (IPEA, 2014).

Tabela 5.5: Serviços - valor adicionado - preços básicos

\begin{tabular}{l|r|r|r|r|r|r}
\hline \multicolumn{1}{c|}{ Município } & \multicolumn{1}{c|}{$\mathbf{1 9 5 9}$} & \multicolumn{1}{c|}{$\mathbf{1 9 7 0}$} & \multicolumn{1}{c}{$\mathbf{1 9 7 5}$} & \multicolumn{1}{c}{$\mathbf{1 9 8 5}$} & \multicolumn{1}{c}{$\mathbf{1 9 9 6}$} & \multicolumn{1}{c}{$\mathbf{2 0 0 1}$} \\
\hline Araguaína & 91,53 & $26.585,99$ & $77.145,46$ & $86.424,44$ & $204.892,52$ & $309.431,23$ \\
Gurupi & $3.833,42$ & $15.944,08$ & $34.910,00$ & $60.810,14$ & $168.070,42$ & $195.060,48$ \\
Itacajá & 319,08 & $1.428,90$ & $2.491,53$ & $3.747,13$ & $3.074,53$ & $8.891,53$ \\
Pedro Afonso & $1.158,73$ & $3.046,67$ & $4.121,22$ & $5.331,78$ & $11.321,01$ & $19.945,07$ \\
Porto Nacional & $2.184,62$ & $11.774,15$ & $22.708,58$ & $20.927,48$ & $77.840,83$ & $84.020,22$ \\
\hline
\end{tabular}

Fonte: IPEA (2014, adaptado pelo autor)

Diferentemente do setor industrial que em 1959 não possui unidade e nem valor adicionado para as cidades de Araguaína e Itacajá, conforme se nota pela Tabela 5.5, o setor de Serviços do PIB apresenta unidades de serviços e valor adicionado para todas cidades aqui citadas. Constata-se que, nesse mesmo ano, todas cidades apresentam um crescimento astronômico em relação à Araguaína. Itacajá cresceu.

Araguaína, dez anos após ter sido alcançada pela rodovia Transbrasiliana, em 1970, com sobressalto nos anos subsequentes, ultrapassa todas as demais cidades correlatas, sendo que todas essas cidades mantiveram-se em constante crescimento nos anos subsequentes, exceto Itacajá que, em 1996, apresentou queda de 26\% do valor adicionado em relação ao ano de 1985.

Neste contexto é importante ressaltar que, apesar da inexistência de indústria tanto em Itacajá quanto em Araguaína, no período que compreende o início da construção da rodovia Transbrasiliana, o setor de Serviços e Agropecuária do PIB em Itacajá gerava demanda tanto para a população não indígena quanto para a população indígena, que recebia recursos financeiros do Governo Federal através do Serviço de Proteção ao Índios (SPI), hoje Fundação Nacional do Índio (FUNAI), e, por essa razão, o PIB itacajaense torna-se mais elevado que o PIB de Araguaína. 
Importante observar, também, que Araguaína fora alcançada com a construção da rodovia Transbrasiliana mais de dois anos após Gurupi, que foi em 1957 e que Pedro Afonso e Porto Nacional por serem velhos centros econômicos regionais já possuíam um consolidado setor de serviços.

Todos os setores que compõe o PIB, Agropecuária, Indústria e Serviços salientados referenciando as cidades de Araguaína, Gurupí, Itacajá, Pedro Afonso e Porto Nacional nas Tabelas nos três setores evidenciam que a construção da rodovia Transbrasiliana (BR-153) promoveu significativas mudanças econômicas em Araguaína e Gurupi, ressaltando que as mudanças ocorridas foram maiores em Araguaína que nas demais cidades.

\subsubsection{PIB}

A consolidação dos dados econômicos dos setores Indústria, Agropecuária e Serviços de um período observado resultam no Produto Interno Bruto, o PIB. Neste sentido, conforme (Tabela 5.6) o PIB de Araguaína, valor adicionado a preços básicos do ano de 2000 em reais (mil R\$), que, em 1959, era menor inclusive que o PIB de Itacajá, em 1970 expõe um crescimento muito acima do apresentado em 1959, enquanto que Itacajá cai 5\% e Pedro Afonso 9\%, fora os $45 \%$ que perdera entre 1949 e 1959. Araguaína, ultrapassa, ainda, a cidade de Gurupi que, apesar de ter a mesma idade, possui um PIB muito superior e, também, de Porto Nacional que, no Censo anterior tinha apresentado queda de $20 \%$.

Importante observar que, nos sensos de 1975 e 1980, houve elevação do PIB de todas cidades referenciadas bem como, nos sensos apresentados entre 1996 e 2000, lembrando que o estado do Tocantins foi criado em 1989 e teve bastante incentivo do Governo Federal. Além disso, cabe salientar que as cidades que tiveram perdas ou deixaram de ter ganho de capital na construção da rodovia Transbrasiliana, quando da formação do estado do Tocantins tiveram ganho muito superior às cidades que tiveram ganho na construção da Transbrasiliana. Ainda sobre a evolução do PIB das cidades em questão, Araguaína, em 2010, apresenta o maior valor adicionado do PIB, 857.958,00 reais (mil R\$), com 74\% acima do segundo maior PIB, que é de Gurupi (Tabela 5.6). 
Tabela 5.6: Crescimento do PIB ente os anos de 1959 e 2010

\begin{tabular}{l|r|r|r|r|r|r|r|r|r}
\hline \multicolumn{1}{c|}{ Município } & $\mathbf{1 9 4 9}$ & \multicolumn{1}{|c|}{$\mathbf{1 9 5 9}$} & \multicolumn{1}{c|}{$\mathbf{1 9 7 0}$} & \multicolumn{1}{c}{$\mathbf{1 9 7 5}$} & \multicolumn{1}{c|}{$\mathbf{1 9 8 0}$} & \multicolumn{1}{c}{$\mathbf{1 9 9 6}$} & \multicolumn{1}{c|}{$\mathbf{2 0 0 0}$} & \multicolumn{1}{c}{$\mathbf{2 0 0 4}$} & \multicolumn{1}{c}{$\mathbf{2 0 1 0}$} \\
\hline Araguaína & & 1.825 & 44.045 & 99.755 & 272.634 & 267.297 & 443.060 & 651.105 & 857.958 \\
Gurupi & & 11.344 & 29.685 & 48.467 & 96.938 & 243.363 & 341.235 & 389.104 & 492.113 \\
Itacajá & & 5.891 & 5.625 & 7.284 & 13.105 & 5.727 & 11.709 & 18.004 & 25.465 \\
Pedro Afonso & 12.853 & 7.008 & 6.365 & 7.663 & 12.482 & 17.832 & 62.291 & 103.833 & 98.491 \\
Porto Nacional & 21.303 & 17.094 & 23.729 & 40.172 & 78.841 & 105.700 & 116.046 & 191.848 & 299.361 \\
\hline
\end{tabular}

Fonte: IPEA (2014, adaptado pelo autor)

O PIB no município de Araguaína, com uma economia em constante crescimento e bastante expressivo para o estado do Tocantins, e que atualmente representa em torno de $11 \%$ de participação no estado, período em que ocorreu a incorporação ao estado, entre 1996 e 2000, foi acrescido em suas economias por um PIB de por volta de $66 \%$. O município, mantendo-se em constante crescimento, nos últimos dados aqui apresentados, no período de 2006 a 2010, percebeu uma evolução de $22 \%$, acima, portanto, dos valores estaduais e nacionais.

O empreendedorismo no município de Araguaína tem um crescimento médio anual de 15\%, o mesmo percentual de crescimento de empresas no estado do Tocantins, conforme CNC (2015). Quanto à sobrevivência dessas empresas após abertura, a taxa é superior ao percentual de empresas que sobrevivem no estado do Tocantins, ultrapassando inclusive a capital Palmas. Na cidade, a cada 100 empresas abertas, 81 permanecem no mercado até dois anos após sua abertura. Esta taxa corresponde a $81 \%$, ultrapassando a taxa da capital Palmas que é de $71 \%$ e do próprio estado que é de 74\%, segundo ACIARA (2015).

Das razões da considerável taxa de sobrevivência e crescimento de empresas do município de Araguaína, não se pode deixar de destacar os incentivos dados pela prefeitura do município, como por exemplo, o programa "Minha Empresa Minha Vida", seguido de um pacote de projetos de lei lançados em 2013, garante a redução da carga tributária para alguns segmentos econômicos, diminuição da burocracia para transações empresariais, ampliação de oportunidades de infraestrutura física, regularização, capacitação empreendedora, financiamentos para pequenas e micro empresas, empreendedores individuais e empreendimentos solidários (ASCOM, 2013).

\subsection{ASPECTOS DO DESENVOLVIMENTO ECONÔMICO}

Apesar de estudiosos afirmarem que o desenvolvimento econômico adentrou o norte do estado de Goiás a partir da abertura da rodovia Transbrasiliana, tal desenvolvimento não foi homogêneo. O 
desenvolvimento da região norte do estado conservou-se, em parte, às margens da rodovia, em um corredor central, onde tornou-se possível a movimentação de pessoas e transporte de bens e serviços produzidos.

Com isso, a população das cidades não contempladas com acesso pavimentado, especialmente as que ficaram à margem direita do rio Tocantins, continuou com baixo desenvolvimento humano, alto índice de analfabetismo, renda muito baixa, poucas cidades com sistema de abastecimento de água pluvial e sem tratamento, baixa expectativa de vida ao nascer, poucas cidades com ruas pavimentadas de forma geral condições de vida inferior as condições de vida da população atendida pela rodovia.

Em proporções menores ao crescimento econômico, o desenvolvimento econômico de Araguaína também apresenta notável evolução no pós-abertura da rodovia Transbrasiliana. Apesar de, inicialmente, o desenvolvimento econômico não ter conseguido acompanhar o crescimento populacional, não deixou de ser expressivo em relação as outras cidades que vêm sendo mencionadas ao longo deste trabalho.

Ribeiro et al (2013) faz referência ao que se considera como o ponto de partida do desenvolvimento econômico de Araguaína:

O autêntico desenvolvimento econômico-social do município começou na realidade a partir de 1960, com a construção da rodovia Belém-Brasília, o que fez com que a cidade crescesse exorbitantemente em relação às demais cidades próximas que eram maiores e mais antigas que ela. No período de 1960 a 1975, Araguaína atingiu um estágio de desenvolvimento sem precedentes na história do Estado de Goiás (...) (RIBEIRO ET AL, 2013).

Araguaína exerce influência com os elementos que compõem o desenvolvimento econômico em cidades do estado do Tocantins, inclusive dos estados do Maranhão e Pará, no mesmo raio que exerce influência com o crescimento econômico, que é de aproximadamente $200 \mathrm{~km}$.

A educação, saúde ou longevidade e a renda, elementos que, internacionalmente, são utilizados nos indicadores de desenvolvimento econômico em uma série histórica, a partir da abertura da rodovia Transbrasiliana, conjuntamente com outros dados apresentados neste trabalho, serão estudados para avaliar a relação do desenvolvimento econômico de Araguaína com a abertura da rodovia. 
Os índices de desenvolvimento humano de Araguaína, entre os anos de 1970 e 1980, foram disponibilizados pelo IPEA e os do período de 1991 a 2010 foram também disponibilizados pelo Atlas do Desenvolvimento Humano disponibilizado pelo PNUD em 2013, contudo, verificaramse divergências nos cálculos apresentados entre ambas instituições. A partir do censo de 2000, introduziu-se no cálculo os índices complementares como Indicadores de Desenvolvimento Humano ajustado à Desigualdade (IDHAD); Índice de Desigualdade de Gênero (IDG) e Índice de Pobreza Multidimensional (IPM).

Tendo em vista as alterações ocorridas nos cálculos constantes nas bases de dados das instituições nos períodos que seguem à abertura da rodovia BR-153, optou-se por apresentar o desenvolvimento econômico de Araguaína em dois períodos distintos: o pós abertura da BR-153, entre os anos de 1970 a 1980, com o intuito de apresentar os efeitos econômicos e sociais provocados no município com a construção da rodovia e também o status do município no pós criação do estado do Tocantins, período entre 1991 a 2010.

Transcorrido o período que o desenvolvimento econômico de Araguaína com seu indicador IDHM em constante crescimento, que, conforme levantamentos feitos, foi alavancado pela construção da BR-153 no final dos anos 80, iniciou-se uma nova fase do desenvolvimento econômico do município: a divisão do estado de Goiás, criação do estado do Tocantins e indexação de Araguaína ao recém estado criado.

No período observado, no pós-criação do estado do Tocantins, 1991 a 2010, enquanto Araguaína e Gurupi tiveram incremento no desenvolvimento humano de $67 \%$ e $53 \%$, respectivamente, Itacajá teve $97 \%$, Pedro Afonso 74\% e Porto Nacional 75\%, taxas maiores do que as duas primeiras que apresentam índices econômicos muito maiores no pós-abertura da BR-153, entre 1970 a 1980 (Tabela 5.7).

Tabela 5.7: Taxa do desenvolvimento humano entre os anos 1970 a 2010

\begin{tabular}{l|c|c|c|c}
\hline \multicolumn{1}{c|}{ Município } & $\begin{array}{c}\mathbf{1 9 7 0 /} \\
\mathbf{1 9 8 0}(\boldsymbol{\%})\end{array}$ & $\begin{array}{c}\mathbf{1 9 9 1 /} \\
\mathbf{2 0 0 0}(\boldsymbol{\%})\end{array}$ & $\begin{array}{c}\mathbf{2 0 0 0 /} \\
\mathbf{2 0 1 0}(\boldsymbol{\%})\end{array}$ & $\begin{array}{c}\mathbf{1 9 9 1 /} \\
\mathbf{2 0 1 0}(\boldsymbol{\%})\end{array}$ \\
\hline Araguaína & 66 & 29 & 30 & 67 \\
Gurupí & 86 & 23 & 24 & 53 \\
Itacajá & 28 & 37 & 44 & 97 \\
Pedro Afonso & 31 & 30 & 34 & 74 \\
Porto Nacional & 48 & 33 & 32 & 75 \\
\hline
\end{tabular}

Fonte: IPEA e PNUD (2009 e 2013, adaptado pelo autor) 
Considerando a evolução das dimensões que compõem o desenvolvimento humano em Araguaína, principal cidade objeto deste trabalho, entre os 1970 e 1980, pode-se afirmar que houve um alto nível de desenvolvimento, pois apresenta um crescimento de 66\%. Esse resultado deve-se, especialmente, à elevação da renda, que foi aproximadamente três vezes. Os demais elementos que compõem o IDHM, educação e longevidade, acompanharam com crescimento muito menores de $27 \%$ e $35 \%$, respectivamente.

A Tabela 5.8 apresenta os valores absolutos das dimensões consolidadas do IDHM extraídas das duas bases de dados do IPEA e PNUD.

Tabela 5.8: IDHM nos anos 1970, 1980, 1991, 2000, 2010

\begin{tabular}{l|r|r|r|r|r}
\hline \multicolumn{1}{c|}{ Araguaína } & $\mathbf{1 9 7 0}$ & $\mathbf{1 9 8 0}$ & $\mathbf{1 9 9 1}$ & $\mathbf{2 0 0 0}$ & $\mathbf{2 0 1 0}$ \\
\hline Educação & 0,379 & 0,481 & 0,230 & 0,431 & 0,712 \\
Longevidade & 0,389 & 0,525 & 0,647 & 0,708 & 0,821 \\
Renda & 0,252 & 0,693 & 0,616 & 0,638 & 0,727 \\
Total da média do município & 0,340 & 0,566 & 0,451 & 0,580 & 0,752 \\
\hline
\end{tabular}

Fonte: IPEA e PNUD (2010 e 2013, adaptado pelo autor)

No período da construção da rodovia BR-153 houve expressiva evolução da renda, com o desencadeamento econômico proporcionado pela indústria, comércio e serviços. A Educação e a Longevidade que, nesse período, tiveram índices menores de crescimento, foram afetadas pelo crescimento exponencial da população e, pelo fato do município não ter conseguido demandar escolas e serviços relacionados, as taxas relativas à educação não tiveram expressividade de crescimento em relação as demais cidades. Quanto à Longevidade, somada às questões de saúde pública, faziam-se presentes os casos de violência urbana os quais, no auge da expansão econômica do município, eram muito comuns em toda a população, afetando diretamente o indicador longevidade.

Segundo os primeiros dados obtidos do PNUD, dos 5.565 municípios brasileiros no ano de 1991, Araguaína ocupava a $1572^{a}$ posição do ranking nacional; em 2010 ocupa a $508^{\circ}$ posição, ficando acima da média do Brasil, do próprio estado do Tocantins, de mais 22 estados e de 9 capitais brasileiras. Em relação aos 139 municípios tocantinenses, Araguaína ocupa a $4^{a}$ posição do IDHM, sendo que 3 (2,16\%) municípios estão em situação melhor e $136(97,84 \%)$ municípios estão em situação pior ou igual, ficando atrás apenas das cidades de Palmas, a capital, Paraíso e Gurupi. O Índice de Desenvolvimento Humano Municipal (IDHM) de Araguaína foi de 0,752, em 2010. O município está situado na faixa de Desenvolvimento Humano Alto entre 0,7 e 0,799. 
Considerando-se as dimensões do desenvolvimento humano, pode-se afirmar que a renda do araguainense é alta, a longevidade muito alta e a educação alta. Em relação ao índice geral de Araguaína esse pode ser considerado na faixa do IDHM como alto. Apesar da longevidade ter o maior nível do desenvolvimento humano, foi a educação que mais cresceu. Entre os anos de 1991 e 2010 cresceu em torno de $210 \%$, enquanto a longevidade cresceu $27 \%$ e a renda $18 \%$.

Quanto à longevidade, o nível de vida está em torno de 74 anos, enquanto que, em 1991, a expectativa de vida era de 64 anos. Quanto à renda per capita, em 1991 girava em torno de R\$ 370,00; já em 2010, essa passou para $\mathrm{R}$ \$ 737,63, um pouco acima do valor do salário mínimo atual que é de $\mathrm{R} \$ 724,00$.

Nos parágrafos a seguir apresenta-se, com maior detalhamento, cada dimensão do desenvolvimento humano, privilegiando as dimensões as quais tem à disposição dados da série histórica.

\subsubsection{Renda}

A dimensão Renda do IDHM usa como critério para calcular a renda média de cada pessoa a renda municipal per capita, ou seja, a renda média de cada residente no município. Para se chegar a esse valor, soma-se a renda de todos os residentes e divide-se pelo número de pessoas que moram no município, inclusive crianças ou pessoas com renda igual a zero. A cidade brasileira que possui o maior IDHM Renda é São Caetano do Sul SP, seguida de Niterói-RJ e Vitória - ES com 0,891, 0,887 e 0,876 , respectivamente.

Entretanto, nesse quesito os três IDHM Renda mais baixos do país estão no estado do Maranhão e são os municípios de Marajá do Sena, Fernando Falcão e Belágua com os índices 0,400, 0,417 e 0,417, respectivamente. Conforme níveis definidos pelo PNUD, Araguaína está num nível alto do ranking geral, abaixo da média de renda brasileira e acima da média de renda tocantinense, cujo valor medido em 2010 foi de 0,727 .

Na comparação entre os períodos 1970/1980 e 1991/2010, que compreendem a construção da BR153 e a criação do estado do Tocantins, no primeiro, as cidades tocantinenses apontam crescimento exponencial da renda acima do segundo, com destaque para Gurupi que cresceu a mais, duas vezes e meio, exceto Itacajá que cresceu 51\%. No segundo período 1991/2010, o contrário ocorre com 
as cidades de Itacajá e Gurupi, delas a que mais cresceu foi Itacajá e a que menos cresceu Gurupi, as demais cidades ficaram com média de 17\% (Tabela 5.9).

Observa-se que a criação do estado do Tocantins privilegia as cidades com menores taxas de crescimento da dimensão Renda. Verifica-se, ainda, a cidade que tem a maior dimensão Renda é Gurupi com 0,736 e quem tem a menor é Itacajá com 0,585.

Tabela 5.9: Crescimento da dimensão Renda do IDHM

\begin{tabular}{l|c|c|c|c|c}
\hline \multicolumn{1}{c|}{ Município } & $\begin{array}{c}\text { IDHM-R } \\
1970 \mathrm{i}\end{array}$ & $\begin{array}{c}\text { IDHM-R } \\
1980 \mathrm{i}\end{array}$ & $\begin{array}{c}\text { IDHM-R } \\
1991 \mathrm{a}\end{array}$ & $\begin{array}{c}\text { IDHM-R } \\
2000 \mathrm{a}\end{array}$ & $\begin{array}{c}\text { IDHM-R } \\
2010 \mathrm{a}\end{array}$ \\
\hline Araguaína & 0,252 & 0,693 & 0,616 & 0,638 & 0,727 \\
Gurupi & 0,235 & 0,820 & 0,662 & 0,659 & 0,736 \\
Itacajá & 0,122 & 0,184 & 0,440 & 0,536 & 0,585 \\
Pedro Afonso & 0,142 & 0,305 & 0,572 & 0,592 & 0,699 \\
Porto Nacional & 0,153 & 0,408 & 0,588 & 0,619 & 0,699 \\
\hline
\end{tabular}

Fonte: IPEA (2014, adaptado pelo autor)

$\mathrm{Na}$ Tabela 5.10, observa-se que a população economicamente ativa do município de Araguaína corresponde a $68,9 \%$ do total de habitantes ocupados, havendo uma taxa de atividade de $84,4 \%$, enquanto a taxa de desocupação alcançou 34,4\% para o ano de 2010.

Tabela 5.10: Indicadores de ocupação no mercado de trabalho

Ocupação da população de Araguaína

\begin{tabular}{l|r}
\hline População em idade ativa (10 anos e mais) & 124.535 \\
Aposentados & 4.109 \\
População Economicamente Ativa PEA & 105.142 \\
População ocupada & 68.938 \\
População desocupada & 36.204 \\
Taxa de atividade & $84,4 \%$ \\
Taxa de desocupação & $34,4 \%$ \\
População total & 150.484 \\
\hline
\end{tabular}

Fonte: IBGE (2010)

No aspecto da distribuição de renda apresentado na Tabela 5.11, mostra-se que, no período de 2000 a 2010, houve uma pequena queda na faixa dos $10 \%$ e $20 \%$ mais ricos para todas as cidades; dos $20 \%$ mais pobres, praticamente todos tiveram uma ligeira elevação, exceto Itacajá, que foi a que teve ligeira redução; tiveram elevação todos os municípios que estão nas faixas $60 \%$ e $80 \%$ mais pobres. $\mathrm{O}$ explicitado na tabela deixa claro que há uma tendência de melhor distribuição da renda pelo decréscimo do percentual das camadas mais ricas da população. 
Tabela 5.11: Percentual de Apropriação da Renda por Extratos da População do Brasil, Tocantins e alguns municípios do Tocantins, indicadores de 2000 e 2010

\begin{tabular}{l|c|c|c|c|c|c|c|c|c|c|c|c}
\hline \multirow{2}{*}{ Lugar } & \multicolumn{2}{|c|}{$\begin{array}{c}\mathbf{1 0 \%} \text { mais } \\
\text { ricos }\end{array}$} & \multicolumn{2}{c|}{$\begin{array}{c}\mathbf{2 0 \%} \text { mais } \\
\text { ricos }\end{array}$} & \multicolumn{2}{c|}{$\begin{array}{c}\mathbf{2 0 \%} \text { mais } \\
\text { pobres }\end{array}$} & \multicolumn{2}{c|}{$\begin{array}{c}\text { 40\% mais } \\
\text { pobres }\end{array}$} & \multicolumn{2}{c|}{$\begin{array}{c}\text { 60\% mais } \\
\text { pobres }\end{array}$} & \multicolumn{2}{c}{$\begin{array}{c}\text { 80\% mais } \\
\text { pobres }\end{array}$} \\
\cline { 2 - 11 } & $\mathbf{2 0 0 0}$ & $\mathbf{2 0 1 0}$ & $\mathbf{2 0 0 0}$ & $\mathbf{2 0 1 0}$ & $\mathbf{2 0 0 0}$ & $\mathbf{2 0 1 0}$ & $\mathbf{2 0 0 0}$ & $\mathbf{2 0 1 0}$ & $\mathbf{2 0 0 0}$ & $\mathbf{2 0 1 0}$ & $\mathbf{2 0 0 0}$ & $\mathbf{2 0 1 0}$ \\
\hline Brasil & 51,94 & 48,93 & 67,56 & 63,40 & 1,84 & 2,41 & 6,85 & 8,59 & 15,90 & 19,23 & 32,44 & 36,60 \\
Tocantins & 54,15 & 49,03 & 68,28 & 64,01 & 1,58 & 2,24 & 6,84 & 8,41 & 15,96 & 18,67 & 31,78 & 35,99 \\
Araguaína & 49,58 & 46,12 & 64,51 & 61,24 & 2,73 & 3,42 & 8,97 & 10,41 & 18,90 & 21,43 & 35,49 & 38,76 \\
Gurupi & 45,86 & 44,38 & 62,73 & 59,16 & 3,16 & 3,96 & 9,43 & 11,48 & 19,61 & 23,00 & 37,27 & 40,84 \\
Itacajáy & 48,86 & 44,73 & 64,22 & 60,79 & 1,93 & 1,49 & 7,61 & 7,30 & 18,23 & 19,59 & 35,78 & 39,21 \\
Pedro Afonso & 49,95 & 39,32 & 63,71 & 54,72 & 3,16 & 3,84 & 9,72 & 12,13 & 19,81 & 24,57 & 36,29 & 45,28 \\
Porto Nacional & 48,97 & 44,01 & 64,62 & 58,72 & 2,46 & 3,65 & 8,45 & 11,02 & 18,20 & 22,87 & 35,38 & 41,28 \\
\hline
\end{tabular}

Fonte: PNUD (2014, adaptado pelo autor)

Segundo os dados do Censo 2010 do IBGE em relação ao perfil do estado do Tocantins, somadas as classes de rendimento que percebem até 1 salário mínimo $(69,4 \%)$ e de mais de 1 até 2 salários $(15,5 \%)$, pode-se constatar que a maior parte da população está concentrada nesse patamar, com um percentual de aproximadamente $85,0 \%$. Contudo, as faixas de rendimentos maiores de 10 salários mínimos representam apenas $0,8 \%$. O restante, $14,2 \%$, concentra as camadas médias com rendimentos que variam de mais de 2 a 10 salários mínimos e as pessoas que receberam benefícios (Tabela 5.12).

Tabela 5.12: Número de pessoas segundo faixa de rendimento mensal do estado do Tocantins e município de Araguaína

\begin{tabular}{l|c|c|c|c}
\hline \multirow{2}{*}{$\begin{array}{c}\text { Faixa de renda mensal (em } \\
\text { salários mínimos) }\end{array}$} & \multicolumn{2}{c|}{ Tocantins } & \multicolumn{2}{c}{ Araguaína } \\
\cline { 2 - 5 } & Pessoas & Taxa (\%) & Pessoas & Taxa (\%) \\
\hline Até 1/8 salário mínimo & 105.677 & 7,67 & 3.081 & 2,06 \\
Mais de 1/8 a 1/4 de salário mínimo & 141.480 & 10,27 & 10.562 & 7,04 \\
Mais de 1/4 a 1/2 de salário mínimo & 334.367 & 24,27 & 31.036 & 20,70 \\
Mais de 1/2 a 1 de salário mínimo & 375.408 & 27,25 & 46.357 & 30,92 \\
Mais de 1 a 2 de salário mínimo & 213.485 & 15,5 & 32.145 & 21,44 \\
Mais de 2 a 3 de salário mínimo & 66.210 & 4,81 & 9.678 & 6,46 \\
Mais de 3 a 5 de salário mínimo & 45.850 & 3,33 & 7.083 & 4,72 \\
Mais de 5 a 10 de salário mínimo & 29.224 & 2,12 & 3.755 & 2,50 \\
Mais de 10 & 11.693 & 0,85 & 1.706 & 1,14 \\
Com rendimento de sem rendimento & 54.340 & 3,94 & 4.520 & 3,01 \\
\multicolumn{1}{c}{ Total } & 1.377 .734 & 100 & 149.923 & 100 \\
\hline \multicolumn{2}{|c|}{}
\end{tabular}

Fonte: IBGE (2010)

A exemplo do que ocorre no estado, o município de Araguaína possui desníveis acentuados na distribuição da renda da população. Existe, no entanto, ligeira melhoria na distribuição do rendimento mensal quando se compara aos valores estaduais, onde os dados apontam que 60,7\% da população do município de Araguaína encontra-se na faixa de até 1 salário mínimo, 21,4\% 
recebem até 2 salários, 6,4\% ganham de 2 a 3 salários mínimos e o somatório das classes de 3 a 10 salários resulta em $7,2 \%$, enquanto $1,1 \%$ da população residente encontra-se nas faixas de rendimentos superiores a $10 \mathrm{SM}$. Os 3,0\% restantes correspondem à faixa da população que recebeu somente benefícios (Tabela 5.13).

Tabela 5.13: Taxa de ocupação da população com mais de 18 anos

\begin{tabular}{l|r|r}
\hline Ocupação da população de 18 anos ou mais - Araguaína - TO & $\mathbf{2 0 0 0 ( \% )}$ & $\mathbf{2 0 1 0 ( \% )}$ \\
\hline Taxa de atividade - 18 anos ou mais & 67,63 & 69,61 \\
Taxa de desocupação - 18 anos ou mais & 15,71 & 6,42 \\
Grau de formalização dos ocupados - 18 anos ou mais & 43,96 & 55,89 \\
\hline
\end{tabular}

Fonte: PNUD (2014)

Quanto à população com 18 anos ou mais, segundo levantamento do Atlas do Desenvolvimento entre 2000 e 2010, o percentual dessa população economicamente ativa em Araguaína passou de 67,63\%, em 2000, para 69,61\%, em 2010. Ao mesmo tempo, sua taxa de desocupação, ou seja, o percentual da população economicamente ativa que estava desocupada, passou de 15,71\% em 2000, para 6,42\% em 2010 (Tabela 5.14).

Tabela 5.14: Nível educacional da população ocupada com mais de 18 anos

\begin{tabular}{l|r|r}
\hline \multicolumn{1}{c|}{ Nível educacional dos ocupados - Araguaína - TO } & $\mathbf{2 0 0 0 ( \% )}$ & $\mathbf{2 0 1 0}(\boldsymbol{\%})$ \\
\hline Taxa dos ocupados com fundamental completo - 18 anos ou mais & 47,88 & 70,5 \\
Taxa dos ocupados com médio completo - 18 anos ou mais & 30,15 & 52,25 \\
\hline
\end{tabular}

Fonte: PNUD (2014)

Relacionando o número de pessoas com 18 anos ou mais, dos economicamente ativos, nos anos 2000 e 2010, observa-se um crescimento significativo numa taxa aproximada de 68\%. Quanto à população com ensino médio completo com 18 anos ou mais, a taxa de crescimento no mesmo período, foi ainda maior, por volta de $92 \%$, comprovando-se crescimento na formação da classe trabalhadora (Tabela 5.14).

\subsubsection{Educação}

Antes da emancipação de Araguaína, por volta dos anos de 1930, e meio século depois da chegada dos primeiros moradores na região em residência particular, iniciou-se a alfabetização dos moradores do povoado e região. Anos mais tarde, em 1955, foi construída pelo padre católico orionita Pacífico Mecozzi a primeira escola, com bancos de assentos e carteiras coletivas, pregadas em paus enfiados no chão batido, tendo como cobertura palha de babaçu. $\mathrm{O}$ transporte dos materiais 
para a construção da escola foi feito por carroça puxada por juntas de bois (BRUNO, 2008). A partir de então, surgiram outras escolas construídas por particulares, pelo governo e instituições evangélicas.

De acordo com Bruno (2008), os orionitas, dando continuidade aos trabalhos educacionais, em 1963, fundaram uma escola para o ensino fundamental e, em 1971, iniciou-se o ensino médio.

Apesar dos esforços do governo e das igrejas católica e evangélica para tentarem tirar da escuridão do analfabetismo os moradores do município de Araguaína, a avalancha de trabalhadores braçais analfabetos vindos de outras regiões, tanto para trabalhar na construção da rodovia BR-153, quanto para aventurar a sorte nesta nova fronteira agrícola, fez com que Araguaína apresentasse em 1960 uma taxa altíssima de analfabetismo de $60 \%$ entre pessoas com 15 anos e mais, em uma população de 9.103 habitantes (IBGE, 1960). Cidades como Itacajá, Pedro Afonso e Porto Nacional, que não sofreram com imigrações de forma elevada no mesmo ano, apresentam taxas menores de analfabetismo.

Os indicadores dos anos subsequentes, com o incremento de recursos advindos dos incentivos do governo, agropecuária, indústria, comércio e prestação de serviços, fazem com que Araguaína supere as cidades usadas como fator de comparação e apresente taxas menores de analfabetismo.

Conforme apresentado anteriormente no IDHM 2010 do município de Araguaína, a Educação ${ }^{11}$ foi a dimensão que apresentou o maior crescimento da série histórica. Cabe ressaltar, que este componente é responsável pela qualificação dos recursos humanos capazes de gerar riquezas em vários aspectos da economia e da sociedade. Basta observar, nos mais diversos levantamentos e indicadores nacionais e internacionais relacionados à educação, que existe uma relação direta entre o desenvolvimento humano, as riquezas de um país ou uma região e a formação do indivíduo.

A relevância do tema justifica-se na medida em que o processo educativo é visto como propulsor do desenvolvimento integral de um indivíduo e a permanência deste na escola. Fator que possibilita a consolidação do conhecimento dos seus direitos, deveres e valores sociais, à integração e interação harmônica e construtiva com a sociedade, além de contribuir com a melhoria na

\footnotetext{
11 Índice sintético da dimensão Educação que é um dos 3 componentes do IDHM. É obtido através da média geométrica do sub-índice de frequência de crianças e jovens à escola, com peso de $2 / 3$, e do sub-índice de escolaridade da população adulta, com peso de $1 / 3$.
} 
qualificação da mão de obra, aumento da empregabilidade, redução da violência, de boa parte dos casos de saúde pública e demais situações relacionadas à formação do caráter do indivíduo.

Embora o IDHM da cidade de Gurupi tenha ficado maior que o de Araguaína, a dimensão Educação de Araguaína foi maior que a das demais cidades, maior inclusive que a de Gurupi. O crescimento da educação em Araguaína entre 1960 a 1970 cresceu 46\%; vale ressaltar que a maior expressão do crescimento do IDHM de Araguaína foi apresentada entre os anos de 1991 e 2000, após a criação do estado do Tocantins, com um crescimento em torno de $87 \%$, saindo do valor absoluto de 0,230 em 1991 para 0,431 em 2000 (Tabela 5.15).

Tabela 5.15: Crescimento da dimensão Educação do IDHM

\begin{tabular}{l|c|c|c|c|c|c}
\hline \multicolumn{1}{c|}{ Município } & IDHM_E & IDHM_E & IDHM_E & IDHM_E & IDHM_E & IDHM_E \\
& $\mathbf{1 9 6 0}$ & $\mathbf{1 9 7 0}$ & $\mathbf{1 9 8 0}$ & $\mathbf{1 9 9 1}$ & $\mathbf{2 0 0 0}$ & $\mathbf{2 0 1 0}$ \\
\hline Araguaína & 0,222 & 0,379 & 0,481 & 0,230 & 0,431 & 0,712 \\
Gurupi & 0,226 & 0,435 & 0,574 & 0,305 & 0,371 & 0,437 \\
Itacajá & O,207 & 0,367 & 0,400 & 0,111 & 0,218 & 0,491 \\
Pedro Afonso & 0,262 & 0,411 & 0,472 & 0,204 & 0,376 & 0,664 \\
Porto Nacional & 0,253 & 0,394 & 0,478 & 0,203 & 0,406 & 0,701 \\
\hline
\end{tabular}

Fonte: IPEA e PNUD (2014, adaptado pelo autor)

Na Tabela 5.16, observa-se ainda que, em 1960 e 1970, a taxa da dimensão Educação de Porto Nacional e Pedro Afonso ainda era superior à taxa das cidades de Araguaína, Gurupi e Itacajá. Em 1980 e 1991, os dois últimos povoamentos superam às demais. Em 2000 e 2010 a dimensão Educação em Araguaína e Porto Nacional apresentam-se muito superiores que as das demais cidades. Com a criação do estado do Tocantins, as duas cidades viraram pólos educacionais, possuindo, dentre outros cursos superiores, o curso de Medicina.

O primeiro momento do levantamento de dados acerca do contexto educativo da cidade de Araguaína, buscou-se apresentar um estudo histórico comparativo relacionando o nível do IDHM Educação antes e depois da construção da rodovia federal Transbrasiliana (BR-153). A seguir, objetiva-se quantificar e apresentar o desenvolvimento da educação araguainense, após a criação do estado do Tocantins,

Em termos percentuais e absoluto, a partir do ano de 1991, com uma abordagem mais detalhada da rede educacional disponível no município e com números de escolas municipais e estaduais, bem como de universidades e/ou faculdades e os respectivos cursos ofertados e, também, 
disponibilizar dados relacionados à taxa de analfabetismo ${ }^{12}$, índices de desenvolvimento da educação básica e demais dados do nível de escolaridade da população do município.

Ainda sobre o sub índice da dimensão Educação do IDHM, das cidades às margens da BR-153, Araguaína é a que tem a maior taxa de analfabetismo em todas as faixas de idade acima de 15 anos. Entretanto, possui uma taxa de analfabetismo abaixo das cidades Pedro Afonso e Itacajá, com destaque para Itacajá que tem a maior taxa de analfabetismo das cidades. Quanto a Porto Nacional, Araguaína tem taxa superior de analfabetismo entre 15 a 59 anos; acima dos 59 anos, a taxa de analfabetismo de Porto Nacional torna-se inferior à taxa de analfabetismo de Araguaína. Infere-se, com isso, que a elevada taxa de analfabetos de Araguaína pertença ao grupo dos imigrantes que vieram para a construção da Transbrasiliana e da cidade (Tabela 5.16).

Tabela 5.16: Taxa de analfabetismo da população de 15 anos ou mais de idade por grupos de idade $(\%)$

\begin{tabular}{l|c|c|c|c|c|c|c|c}
\hline \multirow{2}{*}{ Municípios } & \multicolumn{2}{|c|}{ Total (\%) } & \multicolumn{2}{c|}{$\begin{array}{c}\text { 15 anos a } \\
\mathbf{2 4} \text { anos (\%) }\end{array}$} & \multicolumn{2}{c|}{$\begin{array}{c}\text { 25 anos a } \\
\text { 59os (\%) }\end{array}$} & \multicolumn{2}{c}{$\begin{array}{c}\text { 60 anos ou } \\
\text { mais (\%) }\end{array}$} \\
\cline { 2 - 9 } & $\mathbf{2 0 0 0}$ & $\mathbf{2 0 1 0}$ & $\mathbf{2 0 0 0}$ & $\mathbf{2 0 1 0}$ & $\mathbf{2 0 0 0}$ & $\mathbf{2 0 1 0}$ & $\mathbf{2 0 0 0}$ & $\mathbf{2 0 1 0}$ \\
\hline Araguaína & 13,4 & 8,6 & 3,8 & 1,2 & 13,3 & 7,2 & 50,9 & 38,7 \\
Gurupi & 9,4 & 6,4 & 2,4 & 1,0 & 8,5 & 5,0 & 39,5 & 27,6 \\
Itacajá & 26,4 & 18,2 & 13,0 & 7,0 & 25,0 & 16,1 & 57,7 & 43,3 \\
Pedro Afonso & 15,9 & 10,5 & 5,0 & 2,0 & 14,9 & 8,5 & 47,6 & 41,0 \\
Porto Nacional & 14,5 & 9,2 & 4,7 & 1,6 & 14,1 & 7,8 & 47,5 & 33,7 \\
\hline
\end{tabular}

Fonte: IBGE (2014, adaptado pelo autor)

As próximas tabelas apresentam a situação de Araguaína comparada aos municípios mais populosos do estado para os anos censitários de 1991 e 2000, no que se refere à frequência à escola, taxa de alfabetização e frequência a curso superior. É possível notar que Araguaína mostrou um crescimento de $24,0 \%$ na taxa de crescimento de frequência à escola. Os resultados mais expressivos verificaram-se em Palmas, com 53\% e Paraíso do Tocantins, com 40\%. Neste sentido, Araguaína apresenta uma taxa menor em relação as demais cidades, 24\% (Tabela 5.17).

\footnotetext{
12 De acordo com o IBGE, a taxa de analfabetismo é a percentagem das pessoas analfabetas (pessoa que não sabe ler e escrever um bilhete simples no idioma que conhece) de um grupo etário, em relação ao total de pessoas do mesmo grupo etário.
} 
Tabela 5.17: Taxa de crescimento de frequência escolar e total de estudantes que frequentavam as redes de ensino em todos os níveis

\begin{tabular}{l|c|c|c}
\hline \multirow{2}{*}{ Municípios } & \multicolumn{2}{c|}{ Anos } & $\begin{array}{c}\text { \% de } \\
\text { incremento }\end{array}$ \\
\cline { 2 - 3 } & $\mathbf{2 0 0 0}$ & $\mathbf{2 0 1 0}$ & 24 \\
Araguaína & 71,56 & 88,74 & 28 \\
Gurupi & 72,62 & 92,64 & 28 \\
Miracema do Tocantins & 63,98 & 82,13 & 53 \\
Palmas & 60,72 & 92,81 & 40 \\
Paraíso do Tocantins & 65,45 & 91,76 & 35 \\
Porto Nacional & 72,65 & 97,75 & \\
\hline
\end{tabular}

Fonte: IBGE (2000 e 2010, adaptado pelo autor)

O crescimento da frequência ao curso superior no período de 1991 a 2000 em praticamente todos os municípios do estado do Tocantins com disponibilidade de educação superior foi acima de 100\%. Embora Araguaína também tenha ficado acima de $100 \%$, ou seja, mais do que dobrou o resultado, não obteve taxa tão satisfatória quando comparada aos outros municípios com os mais altos IDHM do estado. Dos municípios que têm uma relativa representação econômica no Tocantins, Porto Nacional apresenta a menor taxa de crescimento da frequência ao ensino superior, 92\% mantendo-se abaixo da taxa de Araguaína. O maior crescimento da taxa de frequência ao curso superior é apresentado por Miracema, superior inclusive a capital Palmas que tem a maior taxa de frequência escolar no estado (Tabela 5.18).

As taxas de frequência das cidades ao ensino superior podem ser submetidas a outras avaliações, como, por exemplo, Porto Nacional que, apesar de ser um dos polos educacionais do estado, tem a menor taxa de estudantes neste nível, seguido por Araguaína. O que se supõe é que exista um número considerável de pessoas formadas nestas cidades.

Tabela 5.18: Taxa de frequência a curso superior

\begin{tabular}{l|c|c|c}
\hline \multirow{2}{*}{\multicolumn{1}{c}{ Lugar/município }} & \multicolumn{3}{|c}{ Taxa de frequência bruta ao ensino } \\
& $\mathbf{1 9 9 1}$ & $\mathbf{2 0 0 0}$ & $\begin{array}{c}\text { Incremento } \\
\text { \% }\end{array}$ \\
\cline { 2 - 4 } & 6,03 & 13,40 & 122 \\
Araguaína & 6,84 & 22,52 & 229 \\
Gurupi & 0,16 & 7,76 & 4750 \\
Miracema do Tocantins & 0,97 & 23,71 & 2344 \\
Palmas & 1,43 & 16,22 & 1034 \\
Paraíso do Tocantins & 8,59 & 16,53 & 92 \\
Porto Nacional &
\end{tabular}

Fonte: PNUD (2014, adaptado pelo autor) 
O desenvolvimento da educação básica brasileira, a partir de 2007, também passou a ser medido pelo Índice de Desenvolvimento da Educação Básica (IDEB) ${ }^{13}$. Este indicador é calculado com base no desempenho do estudante em avaliações do Instituto Nacional de Estudos e Pesquisas Educacionais Anísio Teixeira (INEP) e em taxas de aprovação. Assim, para que o IDEB de uma escola ou rede cresça é preciso que o aluno aprenda, não repita o ano e frequente a sala de aula. Os dados acerca do IDEB na cidade de Araguaína superaram todas as metas definidas pelo MEC e estão demonstrados na Tabela 5.19, abaixo:

Tabela 5.19: Índice de Desenvolvimento da Educação Básica de Araguaína

\begin{tabular}{|c|c|c|c|c|c|c|c|}
\hline & \multirow{2}{*}{ Ano } & \multicolumn{2}{|c|}{$\begin{array}{c}\text { Anos Iniciais do } \\
\text { Ensino Fundamental }\end{array}$} & \multicolumn{2}{|c|}{$\begin{array}{c}\text { Anos Finais do } \\
\text { Ensino Fundamental }\end{array}$} & \multicolumn{2}{|c|}{ Ensino Médio } \\
\hline & & $\begin{array}{c}\text { IDEB } \\
\text { Observado }\end{array}$ & Metas & $\begin{array}{c}\text { IDEB } \\
\text { Observado }\end{array}$ & Metas & $\begin{array}{c}\text { IDEB } \\
\text { Observado }\end{array}$ & Metas \\
\hline \multirow{5}{*}{ Total } & 2005 & 3.8 & - & 3.5 & - & 3.4 & - \\
\hline & 2007 & 4.2 & 3.9 & 3.8 & 3.5 & 3.5 & 3.4 \\
\hline & 2009 & 4.6 & 4.2 & 4.0 & 3.7 & 3.6 & 3.5 \\
\hline & 2021 & - & 6.0 & - & 5.5 & - & 5.2 \\
\hline & 2005 & 3.6 & - & 3.2 & - & 3.1 & - \\
\hline \multirow{3}{*}{$\begin{array}{c}\text { Rede } \\
\text { Pública }\end{array}$} & 2007 & 4.0 & 3.6 & 3.5 & 3.3 & 3.2 & 3.1 \\
\hline & 2009 & 4.4 & 4.0 & 3.7 & 3.4 & 3.4 & 3.2 \\
\hline & 2021 & - & 5.8 & - & 5.2 & - & 4.9 \\
\hline \multirow{4}{*}{$\begin{array}{c}\text { Rede } \\
\text { Privada }\end{array}$} & 2005 & 5.9 & - & 5.8 & - & 5.6 & - \\
\hline & 2007 & 6.0 & 6.0 & 5.8 & 5.8 & 5.6 & 5.6 \\
\hline & 2009 & 6.4 & 6.3 & 5.9 & 6.0 & 5.6 & 5.7 \\
\hline & 2021 & - & 7.5 & - & 7.3 & - & 7.0 \\
\hline \multirow{4}{*}{$\begin{array}{l}\text { Rede Estadual do } \\
\text { Município de } \\
\text { Araguaína }\end{array}$} & 2005 & 4.1 & - & 3.6 & - & - & - \\
\hline & 2007 & 4.3 & 4.2 & 3.6 & 3.6 & - & - \\
\hline & 2009 & 4.6 & 4.5 & 3.9 & 3.8 & - & - \\
\hline & 2021 & - & 6.2 & - & 5.6 & - & - \\
\hline \multirow{4}{*}{$\begin{array}{c}\text { Rede Municipal de } \\
\text { Araguaína }\end{array}$} & 2005 & 4.2 & - & - & - & - & - \\
\hline & 2007 & 4.4 & 4.3 & 3.9 & - & - & - \\
\hline & 2009 & 5.1 & 4.6 & 4.6 & 4.0 & - & - \\
\hline & 2021 & - & 6.3 & - & 5.6 & - & \\
\hline
\end{tabular}

Fonte: Fonte: MEC (2014, adaptado pelo autor)

Por meio da Tabela 5.20 de dados educacionais do INEP do período 2007 a 2010, concernentes ao município de Araguaína, é apresentada a evolução da infraestrutura da rede educacional Municipal e Estadual da educação infantil, ensino fundamental e médio. Nela é demonstrada, também, a oferta da infraestrutura educacional do meio urbano e rural. É importante observar que até 2007, na zona rural não existia qualquer escola de educação infantil; em 2008 teve um salto para 16 escolas e, em

\footnotetext{
${ }^{13}$ Indicador do Ministério da Educação (MEC), utilizado para avaliar o desenvolvimento da educação básica brasileira.
} 
2010, teve o acréscimo de mais uma instalada num assentamento do município, totalizando 17 escolas infantis.

Tabela 5.20: Número de Escolas por Etapa de Ensino - Estadual e Municipal de Ensino em Araguaína

\begin{tabular}{c|c|c|c|c|c|c|c|c|c}
\hline \multirow{2}{*}{ Ano } & \multicolumn{3}{|c|}{ Educação Infantil } & \multicolumn{3}{c|}{ Ensino Fundamental } & \multicolumn{3}{c}{ Ensino Médio } \\
\cline { 2 - 9 } & Urbana & Rural & Total & Urbana & Rural & Total & Urbana & Rural & Total \\
\hline 2007 & 18 & 0 & 18 & 60 & 16 & 76 & 18 & 0 & 18 \\
2008 & 39 & 16 & 55 & 60 & 16 & 76 & 18 & 0 & 18 \\
2009 & 42 & 16 & 58 & 60 & 17 & 77 & 18 & 0 & 18 \\
2010 & 46 & 17 & 63 & 60 & 17 & 77 & 18 & 0 & 18 \\
\hline
\end{tabular}

Fonte: MEC (2014, adaptado pelo autor)

Todo investimento na educação infantil da zona urbana e rural é feito pelo município. Aliás, na zona rural do município não existe escola ofertada pela rede estadual de educação. São 77 as escolas do ensino fundamental, 31 ofertadas pelo estado, 29 pelo município na zona urbana e 17 na zona rural; o ensino médio é 100\% ofertado pela rede estadual e não houve crescimento entre 2007 a 2010.

Os níveis de formação dos professores atuantes na Educação Básica da cidade de Araguaína são bastante diversificados; são compostos por professores com pós-graduação, graduação, licenciatura, ensino médio, normal médio. Em 2009 ainda existia professor sem ensino médio. O município apresentava também variações nos níveis de formação entre os professores da rede estadual e municipal de ensino: os professores da rede estadual possuíam nível de formação maior que os professores da rede municipal. No que concerne ao cenário da educação superior, foi verificado que a formação apresentada pelos professores está entre pós-graduação latu sensu e stricto sensu; observou-se, também, que a rede educacional superior é composta por campi das universidades e faculdades FACDO, ITPAC, FAHESA e UFT.

A Faculdade Católica Dom Orione (FACDO) possui casas e obras assistenciais presentes nos cinco continentes do planeta, sendo a única Instituição de Ensino Superior da congregação no mundo e oferta dois cursos de graduação: Administração e Direito, além dos seguintes cursos de pósgraduação: Gestão em Agronegócios, Gestão Estratégica com ênfase em Logística, Gestão Hospitalar e Saúde Pública e Metodologia do Ensino Superior.

O Instituto Tocantinense Presidente Antônio Carlos (ITPAC) é o mantenedor da Faculdade de Ciências Humanas, Econômicas e da Saúde de Araguaína (FAHESA), que funciona nas mesmas 
dependências do Instituto. Em conjunto, oferecem 11 cursos de graduação, a saber: Administração, Ciências Contábeis, Direito, Educação Física, Enfermagem, Farmácia, Medicina, Odontologia, Pedagogia e Sistema de informação e o mais recente curso de Engenharia de Produção, lançado em 2013. O ITPAC/FAHESA também oferece 5 cursos de pós-graduação lato sensu: Docência Universitária, MBA em Gestão Financeira, com ênfase em Gestão de Custos e Resultados, Treinamento Esportivo, Contabilidade e Direito Tributário e Administração de Banco de Dados.

A Universidade Federal do Tocantins - UFT, criada no ano de 2000, iniciou suas atividades em 2003 com a posse dos primeiros professores efetivos. A UFT tem como missão tornar-se um diferencial na educação e no desenvolvimento de pesquisas e projetos inseridos no contexto socioeconômico e cultural do Estado. O Campus Universitário de Araguaína oferece os seguintes cursos de graduação: Ciências com Habilitação em Matemática, Geografia, História, Letras, Medicina Veterinária e Zootecnia e em nível de pós-graduação stricto sensu Mestrado em Ciência Animal.

O Centro de Educação pólo Araguaína, pertencente à Universidade Anhanguera, oferece apenas os cursos Administração, Ciências Contábeis e Tecnologia em Gestão Hospitalar na modalidade à distância.

\subsubsection{Longevidade}

Apesar dos serviços de saúde terem começado em 1952 com um enfermeiro formado pela Cruz Vermelha Internacional, somente em 1972 inicia-se por católicos orionitas, a construção do primeiro hospital do município de Araguaína, chamado Hospital e Maternidade "Dom Orione", uma instituição particular e filantrópica. A instalação de um hospital público na região também ocorreu após os anos 70, com uma concepção de "bem comum" e "bem estar social", que influiu profundamente nas ações de combate às enfermidades ocorrentes em Araguaína e sua microrregião (DIMAS, 2009).

A dimensão do IDHM, Longevidade sintetiza exatamente as condições de saúde e salubridade de um determinado local, uma vez que, quanto mais mortes houver nas faixas etárias mais precoces, menor será a expectativa de vida observada do local (RIBEIRO ET AL, 2013).

Em Araguaína, embora tenha ocorrido uma melhora na dimensão Longevidade, em torno de 35\% entre os anos de 1970/1980 e 27\% entre os anos de 1991 a 2010, ainda permanece abaixo de boa 
parte das maiores e algumas menores cidades do estado do Tocantins, dentre as quais podemos mencionar Gurupi, Porto Nacional e Pedro Afonso, ficando acima apenas de Itacajá (Tabela 5.21).

Tabela 5.21: Crescimento da dimensão Longevidade do IDHM

\begin{tabular}{l|c|c|c|c|c}
\hline \multicolumn{1}{c|}{ Município } & $\begin{array}{c}\text { IDHM_LL } \\
1970 \mathrm{i}\end{array}$ & $\begin{array}{c}\text { IDHM_L } \\
1980 \mathrm{i}\end{array}$ & $\begin{array}{c}\text { IDHM_L } \\
1991 \mathrm{a}\end{array}$ & $\begin{array}{c}\text { IDHM_L } \\
\text { 2000a }\end{array}$ & $\begin{array}{c}\text { IDHM_L } \\
2010 \mathrm{a}\end{array}$ \\
\hline Araguaína & 0,389 & 0,525 & 0,647 & 0,708 & 0,821 \\
Gurupi & 0,354 & 0,507 & 0,658 & 0,778 & 0,843 \\
Itacajá & 0,388 & 0,535 & 0,613 & 0,662 & 0,798 \\
Pedro Afonso & 0,427 & 0,511 & 0,640 & 0,730 & 0,846 \\
Porto Nacional & 0,415 & 0,538 & 0,640 & 0,708 & 0,826 \\
\hline
\end{tabular}

Fonte: IPEA e PNUD (2014, adaptado pelo autor)

Conforme PNUD (2013), como parte integrante da dimensão Longevidade, a expectativa de vida ao nascer é verificada pelo número médio de anos que um indivíduo viverá a partir do nascimento; entre as cidades do Tocantins, a esperança de vida, tem uma variação média de quatro anos. Em 1970 a expectativa de vida do norte goiano, hoje estado do Tocantins, girava em torno de 50,74 anos; dez anos mais tarde, há um incremento de aproximados 11\%, subindo para 56,49 anos. Após a criação do estado do Tocantins, entre os anos 1991 e 2000, verifica-se um crescimento de mais $7 \%$ ficando com 66,28 anos (IPEA, 2014).

Em 1970, Araguaína apresentava expectativa de vida abaixo da média do estado com 48,36 anos, abaixo inclusive de cidades como Pedro Afonso e Porto Nacional, no entanto, acima de Gurupi e Itacajá que possuíam expectativa de vida menor que Araguaína.

Entre os anos de 1970 e 1980 Araguaína, Gurupi e Itacajá foram as cidades que tiveram as maiores taxas de crescimento da expectativa de vida, acima de Pedro Afonso e Porto Nacional. Das cidades em tela, a que tem a maior quantidade de recurso hospitalares é Araguaína. No estado, Araguaína só não tem mais recursos hospitalares que a capital Palmas. Nos anos subsequentes 1991, 2000 e 2010, todas cidades expostas preservam constantes taxas de crescimento da esperança de vida ao nascer, sendo que Pedro Afonso fica com a maior expectativa de vida, 75,77 anos (Tabela 5.22).

Tabela 5.22: Ranking de Esperança de Vida ao Nascer

\begin{tabular}{l|c|c|c|c|c}
\hline \multicolumn{1}{c|}{ Município } & $1970 \mathrm{i}$ & $1980 \mathrm{i}$ & $1991 \mathrm{i}$ & $2000 \mathrm{i}$ & $2010 \mathrm{a}$ \\
\hline Araguaína & 48,36 & 56,49 & 63,84 & 67,46 & 74,23 \\
Gurupi & 46,22 & 55,39 & 64,45 & 71,68 & 75,60 \\
Itacajá & 48,25 & 57,11 & 63,86 & 70,04 & 72,87 \\
Pedro Afonso & 50,62 & 55,67 & 63,39 & 67,65 & 75,77 \\
Porto Nacional & 49,87 & 57,25 & 63,39 & 67,48 & 74,56 \\
\hline
\end{tabular}


Mortalidade infantil - este indicador contribui com a informação dos níveis de saúde de uma população e, simultaneamente, referencia a qualidade do sistema de saúde e o seu grau de desenvolvimento social e econômico. Em más condições sanitárias o segmento mais afetado é o relativo às crianças. Envolve, portanto, a responsabilidade dos setores públicos na implantação de políticas com relação ao abastecimento de água potável, coleta e destinação do lixo, tratamento de esgotos e a outros serviços públicos que expõem a população a doenças epidemiológicas, infecciosas e de veiculação hídrica como amebíase, giardíase, gastroenterite, febres tifóide e paratifóide, hepatite infecciosa e cólera, entre outras (RIBEIRO ET AL, 2013).

Conforme a Organização Mundial da Saúde (OMS), existem três classificações de Coeficiente de Mortalidade Infantil: Alto - para 50 ou mais óbitos por mil crianças nascidas vivas; Médio - entre 20 e 49 e Baixo, para menos de 20 crianças. O ideal desse índice seria o coeficiente de apenas um dígito, como nos países desenvolvidos como, por exemplo, Suécia com 2,75.

No Tocantins, as cidades, em 1970, tinham um alto coeficiente de mortalidade infantil, uma média de 95,24 óbitos por mil crianças nascidas vivas. As mais jovens cidades Gurupi, Araguaína e Itacajá tinham coeficientes maiores ainda, com 126,34, 110,36 e 111,16 respectivamente. Pedro Afonso e Porto Nacional, cidades mais antiga tinham, coeficientes menores 95,04 e 99,99.

Em 1980, o coeficiente de óbitos infantis em Araguaína cai 44,39\%, tornando-se menor que o de Pedro Afonso, o qual, anteriormente, era menor; mesmo assim, Itacajá e Porto Nacional preservam taxas menores que as de Araguaína. Após a criação do estado do Tocantins, a mortalidade infantil das cidades expressas, entre os anos de 1991 a 2010, teve acentuada queda, ficando abaixo da média nacional, a qual, em 2010, apresentou a taxa de 16,7. Quanto à média estadual, somente Itacajá, com 18,80, não ficou abaixo da média, 19,6, em 2010 (Tabela 5.23).

Tabela 5.23: Coeficiente de Mortalidade Infantil.

\begin{tabular}{l|c|c|c|c|c}
\hline \multicolumn{1}{c|}{ Município } & $\begin{array}{c}\text { Mortalidade } \\
\text { infantil } \\
1970 \mathrm{i}\end{array}$ & $\begin{array}{c}\text { Mortalidade } \\
\text { infantil } \\
1980 \mathrm{i}\end{array}$ & $\begin{array}{c}\text { Mortalidade } \\
\text { infantil } \\
1991 \mathrm{a}\end{array}$ & $\begin{array}{c}\text { Mortalidade } \\
\text { infantil } \\
2000 \mathrm{a}\end{array}$ & $\begin{array}{c}\text { Mortalidade } \\
\text { infantil } \\
2010 \mathrm{a}\end{array}$ \\
\hline Araguaína & 110,36 & 61,37 & 47,90 & 35,38 & 13,06 \\
Gurupi & 126,34 & 67,03 & 45,63 & 23,2 & 12,7 \\
Itacajá & 111,16 & 58,34 & 55,95 & 44,62 & 18,80 \\
Pedro Afonso & 95,04 & 65,55 & 49,61 & 31,25 & 12,40 \\
Porto Nacional & 99,99 & 57,65 & 49,61 & 35,32 & 14,90 \\
\hline \multicolumn{5}{c}{ Fonte: IPEA e PNUD (2014, adaptado pelo autor) }
\end{tabular}


Com base nos índices de internação por doenças infecciosas e parasitárias apresentadas pelo Cadastro Nacional de Estabelecimento de Saúde (CNES), Ribeiro (2013) afirma que Araguaína apresenta quase todos seus índices abaixo dos valores apresentados no estado do Tocantins e no Brasil, excetuando-se apenas a faixa etária de 5 a 9 anos.

Expondo sobre a mortalidade infantil por causa comum, a situação é bastante divergente, apresentando altas taxas, todas maiores que o índice Estadual e Federal, com destaque para a faixa etária de 1 a 4 anos, onde o percentual é muito superior à porcentagem apresentada pelo estado, que é de 19,5\%. Verifica-se, com isso, que a mortalidade está mais associada à eficácia e efetividade do atendimento médico, enquanto a internação está associada ao saneamento básico propriamente dito, o qual pode ser a causa da veiculação e transmissão das doenças Ribeiro (2013).

Saneamento ambiental pode ser definido como conjunto de serviços, obras e ações prioritários em programas de saúde pública. Abrange desde o sistema de abastecimento de água, o cuidado com a destinação do esgotamento sanitário e, as melhorias sanitárias domiciliares até obras de drenagem urbana, controle e foco nas doenças transmissíveis, vetores e roedores, não podendo excluir a preocupação a melhoria das condições sanitária, ambiental, habitação e educação.

Tabela 5.24: Sistema de esgotamento sanitário e resíduo sólido

\begin{tabular}{|c|c|c|c|c|}
\hline \multirow{2}{*}{$\begin{array}{c}\text { Araguaína } \\
\text { Destino Resíduos } \\
\text { sólidos/líquidos }\end{array}$} & \multicolumn{3}{|c|}{ Anos \% } & \multirow{2}{*}{$\begin{array}{l}\text { Nacional } \\
\text { (2013) \% }\end{array}$} \\
\hline & 1998 & 2008 & 2013 & \\
\hline Sistema de Esgoto & 0 & 2 & 5,5 & 41,9 \\
\hline Fossa & 92,8 & 89,7 & 90,6 & 47,8 \\
\hline Céu aberto & 7,2 & 8,3 & 3,9 & 10,3 \\
\hline
\end{tabular}

Os dados da tabela acima demonstram que ainda é recorrente a utilização de fossa pela população de Araguaína, como se pode verificar, em 2013, pelo percentual de quase $91 \%$ da população utilizando, ainda, este tipo de destino de resíduos, não havendo muita alteração no referido percentual se comparado ao ano de 1998, quando o índice era de quase 93\%, demostrando-se, com isso, que ainda é precário o atendimento de sistema de esgoto. 
Tabela 5.25: Sistema de abastecimento de água

\begin{tabular}{c|l|l|l|c}
\hline Araguaína & \multicolumn{3}{|c|}{ Anos \% } & Nacional \\
\cline { 2 - 5 } Abastecimento de água & $\mathbf{1 9 9 8}$ & $\mathbf{2 0 0 8}$ & $\mathbf{2 0 1 3}$ & $\mathbf{( 2 0 1 3 ) \%}$ \\
\hline Rede pública & 87,4 & 89,6 & 87,4 & 77,6 \\
Poço ou nascente & 11,8 & 7,5 & 10,3 & 18,3 \\
Outros & 0,8 & 2,8 & 2,3 & 4,1 \\
\hline
\end{tabular}

Fonte: SIAB (2013)

Quanto ao sistema de rede pública de abastecimento de água em 2013, o índice de 87,4\%, em relação a 1998, mostrou-se inalterado, ou seja, considerando-se que houve aumento na população entre esses anos, significa que, ao se observar o ano de 2008 que teve um percentual de 89,6\%, há deficiências também; contudo, se comparado ao nível da média nacional, que foi de 77,6\%, Araguaína, quanto a esse quesito, superou a média nacional (Tabela 5.25).

Tabela 5.26: Fornecimento de energia elétrica

\begin{tabular}{c|c|c|c|c}
\hline $\begin{array}{c}\text { Araguaína } \\
\text { Fornecimento de } \\
\text { Energia Elétrica }\end{array}$ & $\mathbf{1 9 9 8}$ & $\mathbf{2 0 0 8}$ & $\mathbf{2 0 1 3}$ & \begin{tabular}{c} 
Nacional \\
\cline { 2 - 5 }$(\mathbf{2 0 1 3}) \%$
\end{tabular} \\
\hline Famílias & 13.913 & 39.547 & 39.379 & \\
Percentual & 97,3 & 94,1 & 96,7 & 95,5 \\
\hline
\end{tabular}

Fonte: SIAB (2013)

Ao se analisar os dados da Tabela 5.26 referentes ao fornecimento de energia elétrica do município de Araguaína, verifica-se que a média no município, de quase 97\%, é superior ao nível nacional, o qual também representa um bom índice, em torno de $95 \%$.

Tabela 5.27: Coleta de lixo

\begin{tabular}{l|l|l|l|c}
\hline \multirow{2}{*}{$\begin{array}{c}\text { Araguaína } \\
\text { Serviço de Coleta de Lixo }\end{array}$} & \multicolumn{3}{|c|}{ Anos \% } & $\begin{array}{c}\text { Nacional } \\
\text { (2013) \% }\end{array}$ \\
\hline Coleta pública & 0 & 2 & 6 & 42 \\
Queimado/Enterrado & 93 & 90 & 91 & 48 \\
Céu aberto & 7 & 8 & 4 & 10 \\
\hline
\end{tabular}

Fonte: SIAB (2013)

Com relação ao serviço de coleta de lixo urbano visto na Tabela 5.27, os índices do município de Araguaína referentes aos três parâmetros de coleta pública, queimado ou a céu aberto, apresentamse bem superiores quando comparados ao índice nacional, principalmente o lixo a céu aberto, que 
representa apenas $1,4 \%$, contra $7 \%$ do índice nacional. O índice de coleta pública do município é de 94,2\%, o nacional, de 79,6; portanto, o sistema de coleta de lixo é bem favorável.

Quanto à assistência à saúde em Araguaína no ano de 2009, verifica-se pela Tabela 5.28, que o investimento em saúde pela iniciativa privada é de mais de $100 \%$, em relação à pública, somada à filantropia.

Tabela 5.28: Unidades de Saúde em Araguaína, por Mantenedor

\begin{tabular}{l|c|c|c|c}
\hline \multicolumn{1}{c}{ Tipos de estabelecimentos } & Público & Filantróp. & Privado & Total \\
\hline Centro de Atenção Psicossocial & - & - & 1 & 1 \\
Centro de Saúde/Unidade Básica de Saúde & 20 & - & 1 & 21 \\
Clínica Especializada/Ambulatório Especializado & 3 & 1 & 9 & 13 \\
Consultório Isolado & - & - & 52 & 52 \\
Farmácia Medic. Excecional e Prog. Farmácia Popular & 3 & - & - & 3 \\
Hospital Especializado & 1 & - & 1 & 2 \\
Hospital Geral & 2 & 1 & 1 & 4 \\
Pronto Socorro Especializado & - & - & 2 & 2 \\
Secretaria de Saúde & 1 & - & - & 1 \\
Unidade de Serviço de Apoio diagnose e Terapia & 1 & - & 14 & 15 \\
Unidade de Vigilância em Saúde & 2 & - & - & 2 \\
Unidade Móvel Terrestre & 1 & - & - & 1 \\
& $\mathbf{3 4}$ & $\mathbf{2}$ & $\mathbf{8 1}$ & $\mathbf{1 1 7}$ \\
\hline
\end{tabular}

Fonte: CNES (2009); Org.: RIBEIRO, et al., (2013)

Somados os ambulatórios, postos, centros e unidades básicas de saúde (UBS), o número de unidades da rede pública representa $29 \%$ da cobertura da rede básica, enquanto que a rede privada, com consultórios, clínicas e serviços especializados, supera em $69 \%$ e a filantropia em $2 \%$ em número de estabelecimentos e, pela amostra, o serviço público no atendimento à saúde, mostra-se precário CNES (2009). 


\section{ANÁLISE E AVALIAÇÃO DOS IMPACTOS DA IMPLANTAÇÃO DA BR-153 NO DESENVOLVIMENTO E CRESCIMENTO DE ARAGUAÍNA}

\subsection{INTRODUÇÃO}

Existem diferenças econômicas bastante significativas entre as regiões brasileiras que sugerem, no entanto, uma discussão por vários vieses, especialmente o da infraestrutura de transporte, ressaltando-se sua importância na economia de cada região, com sua situação peculiar, apontando os segmentos dentro da economia que mais se destacam.

Os primeiros traçados de uma extensão longitudinal de infraestrutura de transporte rodoviário pertencem aos planos que faziam parte de um pacote de medidas, os quais objetivavam o desenvolvimento homogêneo do Brasil com a interiorização ou integração nacional, através da construção de uma rodovia na região central do país. Denominaram de tronco médio quatro (TM4), em seguida, mudaram os termos técnicos para BR-14, ficando assim até 1964; a partir desse ano, as rodovias brasileiras passaram por novas definições e o trecho que corta Tocantins e Goiás, que anteriormente era a BR-14, foi redefinida como BR-153 e nos estados do Maranhão e Pará, BR-010 (MAZURAS, 2013).

A referida BR trouxe significativos ganhos para as cidades, as quais estão, conforme dito anteriormente, às margens dela, como por exemplo Araguaína:

Antes da abertura da BR-14, essas terras de matas estavam pràticamente vazias, pois aos rudes fazendeiros, que aí criavam gado à sôlta, interessavam apenas as terras de campo; nas matas se faziam apenas pequenas roças de subsistência. A rodovia, dando acesso aos mercados, valorizou as matas. Uma vigorosa corrente de povoamento afluiu rápida para essas áreas, constituídas de lavradores pobres e sem terras, vindos do Sertão do Nordeste, do Maranhão e Piauí. (VALVERDE e DIAS, 1967).

Somente com o plano de metas do Presidente Juscelino Kubitschek, com a construção da rodovia BR-153, Transbrasiliana, Araguaína teve um novo estímulo para seu crescimento, começando pelos trabalhadores que vieram de diversas partes do país, principalmente dos Estados do Pará, Maranhão e Piauí para a construção da rodovia e pelos serviços gerados em função do número de imigrantes. 
No período da construção da rodovia, no fim dos anos 60 a paisagem típica de predominância era o cerradão e matas de segunda, e as das circunvizinhanças de Araguaína, típica do chapadão, predominante do divisor das bacias dos rios Tocantins e Araguaia, numa faixa de $64 \mathrm{~km}$ por onde atravessava a atual BR-153 (VALVERDE e DIAS, 1967).

Com uma economia voltada para a agropecuária de subsistência, Araguaína, em menos de duas décadas, a contar do início da abertura da rodovia BR-153 no fim dos anos 50, torna-se provedora de produtos primários ao mercado local e nacional; mais tarde torna-se provedora também para o mercado mundial. Neste sentido, mesmo não sendo a principal atividade econômica, sustenta e estende poder político e econômico no espaço urbano e região, apoiando-se em marketing e apropriando-se de investimentos públicos e privados (SILVA, 2012).

Segundo Silva (2012), Araguaína possui infraestrutura urbana e regional e também funciona como cidade mediadora de acumulação capitalista no espaço urbano de empresas privadas nacionais e multinacionais que controlam o beneficiamento e a comercialização da produção regional e nacional. Informa, ainda, que são vários os corredores principais os quais se especializam na distribuição de bens e serviços de apoio à agropecuária capitalista, condição que caracteriza a cidade como expressão desta atividade econômica.

Com a construção da rodovia e possibilidade de escoamento da produção do agronegócio e de madeira, o comércio também teve seu destaque na economia. À margem da BR-153 existia um comércio desordenado, sem separação em setores, composto por lojas como relojoeiro, barbeiro, casas de tecidos e até mesmo instituto de beleza. Juntamente com os estabelecimentos comerciais, negociava-se de tudo, num aspecto de feira livre.

Empresas de Goiânia e Anápolis observando a próspera cidade numa rápida ascensão, não hesitaram em abrir suas filiais na cidade. Podem-se destacar as mais fortes empresas especializadas no comércio de algodão, amendoim, arroz, babaçu, gergelim, semente de girassol e mamona. Como uma das mais importantes empresas destacava-se a Companhia Boa Sorte (VALVERDE E DIAS, 1967).

Para o abastecimento e suprimento das necessidades do comércio existia certa concorrência entre os mercados das regiões do sul e do norte; precisamente de Belém vinham os combustíveis como 
a gasolina, lubrificantes e o gás de cozinha e também outros produtos como telha e sal. Praticamente todos os demais produtos vinham dos mercados do sul. De Anápolis chegava o cimento, feijão roxo, queijo tipo Minas; o comércio de artigos de papelaria era de exclusividade do Rio de Janeiro; o álcool de Goiás; de São Paulo juntamente com Goiás, biscoito; do Rio de Janeiro, medicamentos; de Belo Horizonte, tecidos; de Recife, ferragem e perfumaria. Todo o ferro proveniente de São Paulo era redistribuído em Anápolis (VALVERDE e DIAS, 1967).

Para Brito (2009) a importância da Transbrasiliana foi além da simples via de transporte rodoviário, ela concretizou uma viabilidade econômica para uma região isolada que sofria dificuldades para se desenvolver. O fluxo migratório que se direcionou para o campo, a criação de novos núcleos urbanos e "a reanimação econômica" de outras cidades na região estabeleceram uma nova fase de consolidação e organização socioeconômica. "A rodovia tornou-se um grande eixo de escoamento da produção e de interligação entre o sul que fornece produtos industrializados e o norte, matériasprimas" (BRITO, 2009).

\subsection{CONTRIBUIÇÕES DA BR-153 À ATIVIDADE ECONÔMICA DA CIDADE DE ARAGUAÍNA E MUNICÍPIO}

Um país jovem como o Brasil, pertencente ao grupo dos maiores países do mundo em dimensão territorial e que foi tratado como colônia exclusiva de Portugal e sob domínio da Holanda também, até a recém proclamação da república, servia apenas para extração, exportação e contrabando dos recursos naturais como pedras preciosas, madeira e pele de animais silvestres, aonde muitas pessoas viviam em extrema pobreza, cativas de poucos senhores fazendeiros.

Neste sentido, sendo este povo uma nação que trouxe em seu surgimento, um processo inconsciente de formação, assim como diversos outros, ainda levará alguns anos para a equalização dos recursos econômicos de maneira que as desigualdades sociais não sejam tão grandes quanto àquelas que são vistas por meio dos indicadores socioeconômicos.

Uma das contribuições que tem evidenciado o desenvolvimento e também o crescimento das atividades econômicas são as vias transportes. Para um país novo, com muitas necessidades e deficiências em vários setores da sociedade, torna-se muito pesado o investimento em infraestrutura de transportes; entretanto, este elemento, sob vários aspectos, tira do isolamento o ser humano e a região servida por este recurso. 
Tal realidade é comprovada através de investigações e pesquisas feitas sobre o caso Araguaína, jovem cidade que, outrora isolada e, com apenas 30 anos de existência em 1988 na região mais pobre do estado de Goiás, apresenta-se à frente de várias cidades centenárias de todo estado e se torna a quarta cidade mais importante em atividade econômica. Neste sentido, logo após a criação do estado do Tocantins, Araguaína se tornou a cidade mais importante do recém criado estado e, tempos depois, sua posição no ranking é ocupada pela capital Palmas, que recebe investimentos para ser a sede do governo estadual.

\subsubsection{Caracterização da nomenclatura das rodovias}

Para se entender a nomenclatura dada à rodovia BR-153, verificou-se que, segundo informações disponíveis no Ministério dos Transportes (2014) e Plano Nacional de Viação (1974), a designação das siglas que denominam as rodovias é composta por duas letras seguidas por três números, onde as duas primeiras letras representam por quem é controlada a rodovia: se pelo governo de uma Unidade da Federação ou se pelo próprio Governo Federal; pode-se citar, por exemplo, que uma sigla iniciada por BR identifica que o órgão controlador pertence ao Governo Federal e quando iniciada por TO, é controlada pelo estado do Tocantins. Já os números, que compõem tanto as rodovias federais quanto as estaduais, indicam as direções das rodovias e são eles:

- 0 (zero), para as rodovias radiais;

- 1 (um), para as rodovias longitudinais;

- 2 (dois), para as rodovias transversais;

- 3 (três), para as rodovias diagonais; e

- 4 (quatro) para as rodovias de ligação;

Assim, a rodovia Transbrasiliana, designada pela sigla BR-153, cuja origem foi abordada acima, é uma rodovia longitudinal que atravessa o Brasil pela região central, com o aproveitamento de outras rodovias, fazendo a interligação de Aceguá/RS a Belém/PA e, através da BR-060, interliga o Distrito Federal com as regiões Norte e Sul do país. Nos nove estados, entre Rio Grande do Sul e Pará, pelos quais a rodovia em evidência passa, são poucos os trechos duplicados; existe ainda parte dela na região sul sem pavimentação. O trecho duplicado está entre as cidades de Anápolis GO e Prata-MG e os sem a conclusão da pavimentação, estão nos estados do Paraná e Rio Grande do Sul; a parte da rodovia que passa por Aragaína-TO está pavimentada desde a década de 70. 


\subsubsection{Características das BR's 153 e 010 que cortam o Estado de Tocantins}

Quanto à extensão da BR-153 dentro do estado de Tocantins, essa é de 799,3 km no sentido nortesul, começando em São Geraldo do Araguaia, na divisa de Tocantins com o Pará, e terminando em Talismã na divisa com Goiás. A rodovia cruza as seguintes cidades do estado: Xambioá, Wanderlândia, Araguaína, Nova Olinda, São Sebastião, Colinas do Tocantins, Brasilândia do Tocantins, Presidente Kennedy, Guaraí, Fortaleza do Tabocão, Miranorte, Barrolândia, Paraíso do Tocantins, Pugmil, Nova Rosalândia, Aliança do Tocantins, Gurupí, Figueirópolis, Alvorada, Talismã, e sua classificação é de rodovia longitudinal (DNIT, 2011).

Já a extensão da BR-010 no estado de Tocantins, essa é de 789,1 km; na classificação do tipo de rodovia é uma radial e as cidades em que ela passa são: sentido Brasília-Belém começa na divisa de Tocantins com Goiás e termina em Goiatins, na divisa com o Maranhão e as cidades por onde passa são Paranã, Natividade, Chapada da Natividade, Santa Rosa do Tocantins, Silvanópolis, Monte do Carmo, Palmas, Aparecida do Rio Negro, Rio Sono, Santa Maria do Tocantins, Itacajá e Goiatins (DNIT, 2011).

Sob o aspecto das cidades nas proximidades ou às margens de rodovias federais como a BR-010, em trechos não pavimentados ou sem infraestrutura capaz de fomentar a economia regional e de rodovias como a BR-153, em boas condições de trafegabilidade, é possível perceber, através do IDH com os dados pesquisados no PNUD (2014) e IPEA (2014), que as condições socioeconômicas das cidades localizadas às margens da BR-153 são superiores às cidades que estão às margens da BR-010

Para maior aprofundamento da análise, verificou-se também que, excluindo-se Palmas, que é a maior cidade às margens da BR-010, e Araguaína, que é a maior cidade às margens da BR-153, observa-se maior impacto negativo à média do IDH nas cidades que estão às margens da BR-010. É possível afirmar, no entanto, que a rodovia BR-153 por ser toda pavimentada no estado do Tocantins produz distribuição homogênea do desenvolvimento e recursos econômicos.

Semelhantemente ao que ocorre com o IDH, verifica-se que o PIB mantém o mesmo comportamento, só que em um percentual muito maior que a diferença da taxa média do IDH das cidades que estão às margens da BR-153 e BR-010. Excluindo Palmas, que é a capital do estado, com um PIB cinco vezes maior que a somatória do PIB das demais cidades que estão às margens 
da BR-010 e Araguaína, a qual tem o $2^{\circ}$ maior PIB tocantinense e é a maior das cidades que estão às margens da BR-153, a média (2010) das cidades que estão às margens da BR-010 é menos da metade do que a média do PIB das cidades que estão às margens da BR-153. Cabe observar que, em 1959, o PIB das cidades que estavam às margens da BR-010 era 14\% superior ao das cidades que estão às margens da BR-153 e, em 1970, o contrário ocorrera, com uma diferença de 47\% do PIB das cidades às margens de uma rodovia em relação as cidades que estão às margens da outra.

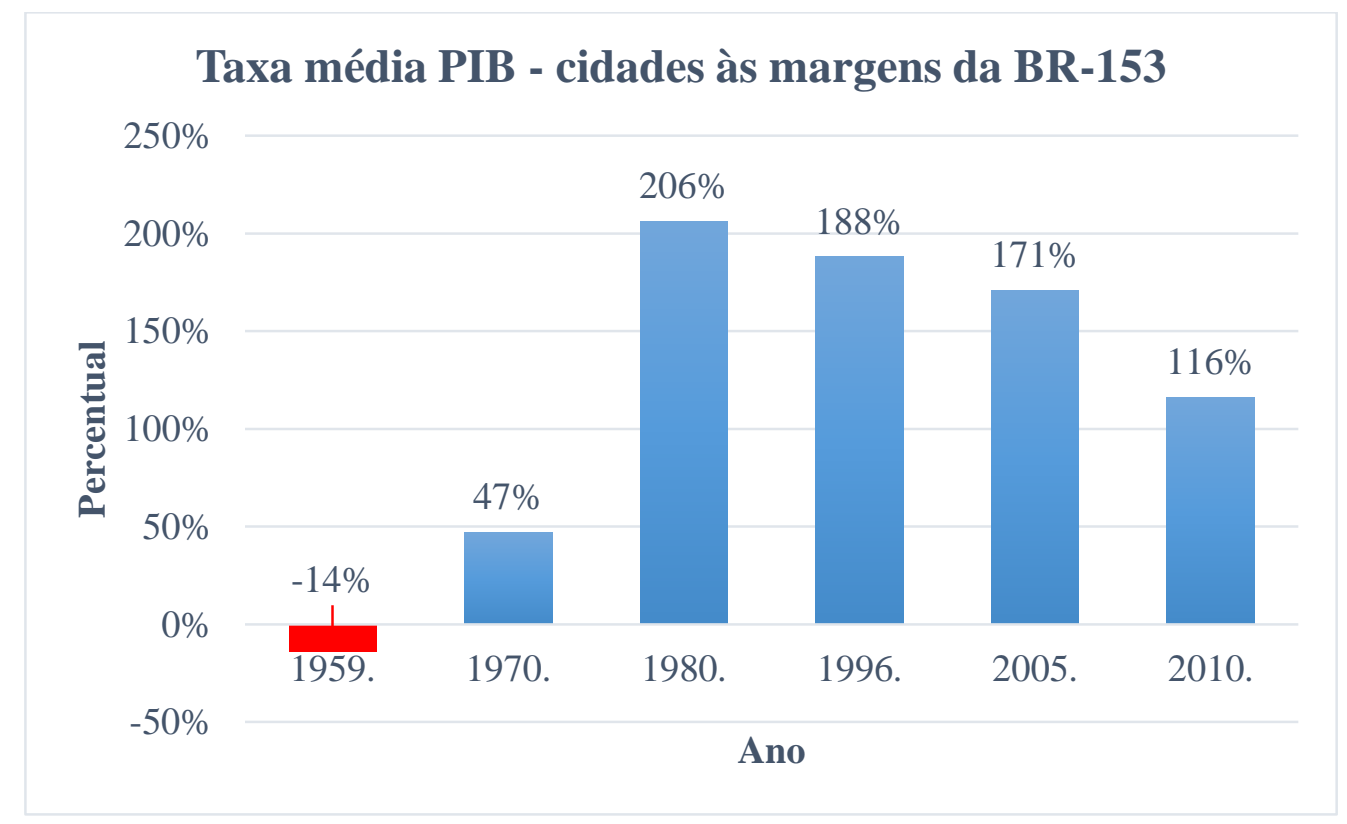

Figura 6.1: Percentual do PIB dos municípios às margens da BR-153 superior ao PIB das cidades às margens da BR-010

Fonte: IPEA (, adaptado pelo autor 2014)

Quanto à apresentação das condições das BR's 153 e 010 no estado do Tocantins, existem pontos críticos praticamente em toda a extensão da BR-010, apontando-se condições boas de trafegabilidade somente entre os trechos que alimentam a capital Palmas. Já a BR-153 encontra-se boa em praticamente toda sua extensão, exigindo apenas atenção entre Figueirópolis e Talismã (Figura 6.2). 


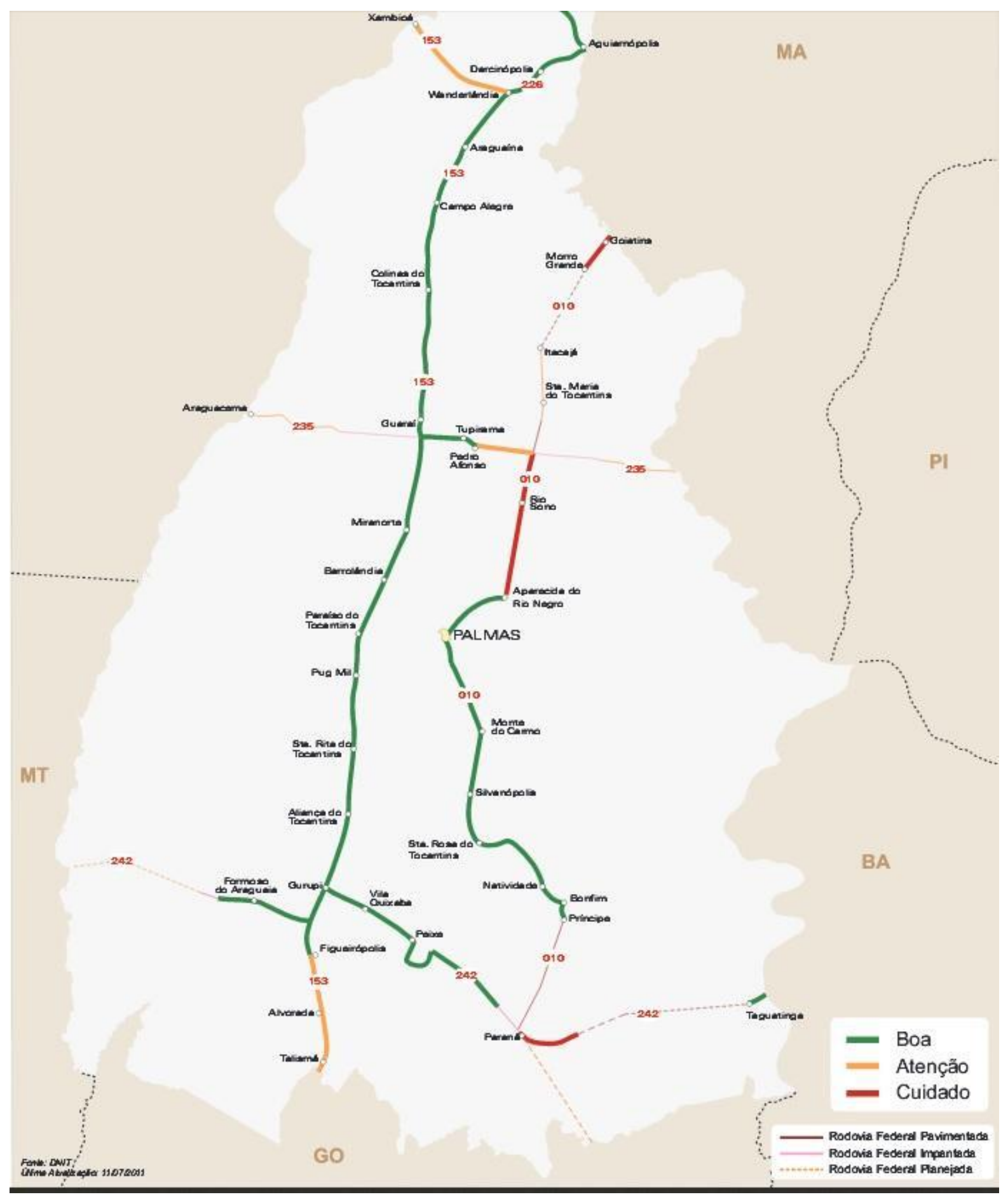

Figura 6.2: Condições das rodovias federais BRs 153 e 010 Fonte: (BIT, 2014)

As péssimas condições da pavimentação das estradas consoante relatório da Agência Nacional de Transportes Terrestres (ANTT) (2006) e totalizam-se apenas 12\% das estradas, correspondendo na prática em $196.244 \mathrm{~km}$ de vias municipais, estaduais e federais. Essa realidade descrita pela ANTT 
é seguida do mau estado de conservação em que se encontram as rodovias, pois 54\% das vias pavimentadas estão em mau estado, $70 \%$ apresentam deficiências na sinalização, $78 \%$ indicam problemas de geometria e 39\% não tem acostamento (VIANA, 2006).

O incremento de custos nas operações de transportes também está relacionado às condições das vias, onde se pode estabelecer uma relação entre o status da rodovia, o crescimento e desenvolvimento econômico, de forma que se for alto o custo em face das deficiências constatadas nas rodovias, a economia será substancialmente prejudicada.

O crescimento de até $58 \%$ no consumo de combustíveis, acréscimo de $40 \%$ no custo operacional dos veículos, aumento de 50\% no índice de acidentes e de até $100 \%$ do tempo de viagem dá-se pela ausência de manutenção das rodovias, que implica reflexos negativos para a atividade econômica. Inclui-se, também, a deterioração de um patrimônio avaliado em US\$ 200 bilhões para os cofres públicos (DNIT, 2005).

Torna-se compreensível que, para cidades como Itacajá, que vivem um isolamento econômico relativo em função da ausência da pavimentação em seus acessos, que interligam a outras cidades, em especial aos centros econômicos existentes no próprio estado do Tocantins. Além disso, a situação permanece pela falta de comprometimento político com as anomalias da geografia espacial do contexto da política pública. A ausência de meios adequados de comunicações "era a causa de grandes perturbações na vida econômica e social dos estados" (GALVÃO, 1996).

Galvão (1996) legitima através da história dos transportes a pavimentação de rodovias e sua perfeita utilização:

O virtual abandono da ideia de se desenvolverem as outras modalidades de transporte esteve sempre baseado na crença de que um moderno sistema de rodovias constituiria a forma mais rápida de se alcançar o grande objetivo nacional da integração social, econômica e política do país. A preferência pela rodovia teria sido, portanto, uma resposta à incapacidade revelada pelas outras modalidades de transporte para atenderem às aspirações nacionais, tendo em vista que os sistemas de transportes existentes eram considerados como inadequados, antiquados, ineficientes e absolutamente incapazes de responderem aos anseios nacionais da unificação territorial do país.

Há ainda de se observar que as desigualdades socioeconômicas, como por exemplo entre Itacajá e Araguaína, relativamente à BR-153, apresentam-se tal qual em face da resultante globalização 
provocada pelo modelo neoliberal. De acordo os setores do PIB e das dimensões do IDH, as cidades tocantinenses expressas neste estudo, a economia, não produziu melhor correspondência entre crescimento econômico e desenvolvimento econômico.

Ocorre que as disparidades econômicas entre regiões e setores da economia estão consubstanciadas em razões muito mais profundas, o que se verifica a priori, por exemplo, para Galbraith (2002) que existem alguns eventos econômicos de escala global, além da inexperiência de governos; contribuem para promover as condições de não redução das desigualdades socioeconômicas. Por sua vez cita Kerstenetzky (2002) que: a razão para a existência de desigualdades no plano dos governos estaria no que há a convicção de que enfrentar a desigualdade não é politicamente realista, além de não haver horizonte normativo para ser respeitado ao mesmo tempo que factível.

Um dos fatores que provoca desigualdades em setores da economia é a redução e corte nos investimentos em setores vitais ao crescimento do país, enquanto políticas públicas, é o que causa maior custo para o setor de transportes, em lugar do equilíbrio da malha rodoviária e, automaticamente, da economia. Neste caso, ainda não se alcançou o pleno desenvolvimento econômico, já que a renda é mal distribuída, causando consequências em diversos outros setores econômicos.

Tomando-se como exemplo a abertura da estrada Transbrasiliana, os incentivos do Estado neste sentido, recentemente, possibilitaram aos agricultores da região aumentar seu excedente comerciável, isto é, viabilizou-se a caminhões chegarem à redondeza, oriundos do sul, em busca de arroz. Destaque para o Banco do Brasil sobre o fomento mercantil ofertado a agricultores para patrocinar suas atividades econômicas (MELLATI, 1967).

A partir da articulação de políticas públicas, pode-se estreitar a distância entre regiões que não possuíam ligação, acessibilidade ao desenvolvimento econômico, bem como a eficiente comunicação entre os setores industriais internos. Observa Mellati (1967): “Assim, indivíduos que cultivavam antes roças de cerca de três tarefas, passaram a plantar extensões de oito ou mais tarefas, sendo obrigados a procurar outros trabalhadores que os ajudassem como diaristas ou empreiteiros."

Já Owen afirma:

Para o transporte rodoviário, substancial capital público é necessário para 
construir a estrada, porém a quantidade pode ser adequada à necessidade, projetando-se estradas de baixo custo para pouco trânsito. O equipamento para o transporte necessário pode exigir mais capital do que as estradas, mas alguma vantagem no fato de que o material rodante é geralmente adquirido pelo setor privado e que um investimento relativamente pequeno para a compra de um caminhão, ou ônibus, é tudo que se necessita para se iniciar o serviço de transporte rodoviário. (OWEN, 1975).

Pelo contexto apresentado sobre os aspectos e os impactos da implantação de rodovias, demostraram trazer mais benefícios para Araguaína do que os aspectos negativos que impactam certamente. Neste momento, passar-se-á para as considerações acerca de todo o trabalho de pesquisa realizado, porém, o assunto não se esgota aqui, pois sempre é considerável abordar outros aspectos e ou mudanças.

A partir de 1960, com a construção da BR-153, Araguaína passou a ser um importante entreposto no extremo norte do então Estado de Goiás, devido à sua localização geográfica, e transformou-se num importante elo entre Norte/Nordeste (RIBEIRO ET AL, 2013). Com isso, começou a alcançar notoriedade econômica na região, tendo como fatores desencadeadores do crescimento econômico a expansão das atividades agropecuária, indústria, comércio e serviços.

\subsubsection{Contribuições à Araguaína advindas da BR-153}

Sob o aspecto rodoviário, Araguaína fez parte de projetos de integração entre as cidades brasileiras fomentados pela rodovia Transbrasiliana BR-153, também conhecida por rodovia BelémBrasília e Rodovia Bernardo Sayão. A BR-153 é um patrimônio rodoviário que liga vários estados federados enquanto resultado do processo de construção do mercado interno brasileiro.

Antes da construção da BR-153, a atividade econômica em Araguaína era eminentemente pequena, porém, com a construção da rodovia e incentivos do governo, surgiram grandes estabelecimentos agropecuários, industriais, escolas, hospitais e elementos que compõem o contexto do crescimento e desenvolvimento econômico representado pelo PIB (Figura 6.3) e IDH, transformando a cidade num grande centro para a região, nos aspectos, sociais, econômicos e populacionais. No entanto, prejudicou cidades não contempladas com rodovias, que eram referências econômicas, como Porto Nacional/TO e Pedro Afonso/TO. 


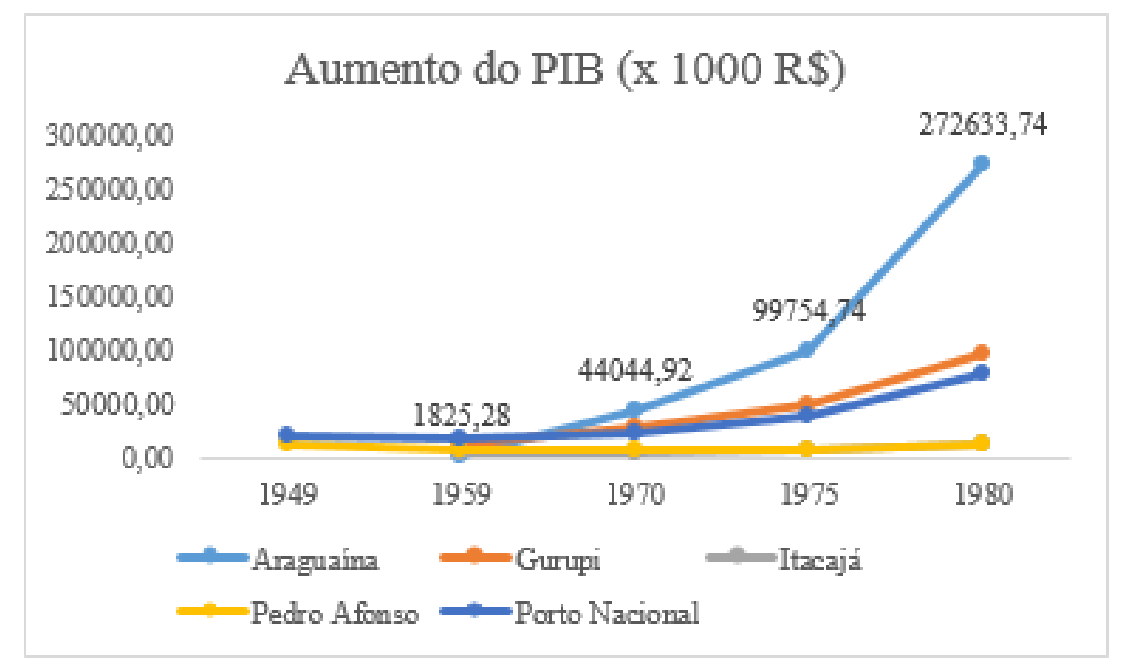

Figura 6.3: Faz referência ao crescimento econômico de antes e depois da BR-153 de Araguaína e cidades correlatas

Fonte: IBGE (2012, adaptado pelo autor)

Nas concepções de Lopes (2008), com referidas ações a sociedade pioneira da região avançou em rumo à atividade agrícola. Vale lembrar, também, que, através da BR-153 e parte da BR-010, o Norte acessa a Região Geoeconômica Centro-Sul do Brasil e, tendo por certo grande fluxo de veículos nessa rodovia, promove, assim, a integração nacional brasileira.

Não muito diferente de Lopes, Peixoto (1977) ao explanar a historiografia dos transportes e a importância deles, com o intuito de mostrar como o pioneirismo contribuiu para a instalação de intenso fluxo de transportes nas rodovias, disse que:

A função pioneira e desbravadora, até então atribuída às ferrovias, foi gradativamente se transferindo para as rodovias, e o contínuo aperfeiçoamento dos veículos automóveis se encarregou de elevar cada vez mais a importância econômica, social e política do transporte rodoviário. A função primordial das estradas de ferro passou a ser o transporte de cargas a grandes distâncias. Onde não houvesse grande volume de carga a transportar, não podia haver exploração ferroviária econômica. Nossa rede ferroviária, construída ao sabor das circunstâncias, fora de qualquer plano de conjunto e já estão operando em precárias condições, não acompanhou a expansão rodoviária. O abandono a que foram relegadas as ferrovias afugentou os fretes para as rodovias, agravando assim o déficit de quase todas as empresas ferroviárias do País. A participação da rodovia nos transportes foi crescendo de maneira absorvente.

Nesse aspecto sobre a função da rede ferroviária à época, Oliveira Júnior (1996), também apresenta o seguinte comentário: 
A ferrovia traz soluções tanto no nível urbano quanto no nível regional, respectivamente, no deslocamento urbano e no escoamento da produção. A utilização da intermodalidade dos transportes juntamente com outras políticas públicas estaduais é condição suficiente ao desenvolvimento regional.

De outra forma, o capital expandiu-se em direção à agricultura pois, devido à localização de Araguaína, ocorreu a entrada de grande contingente populacional, demonstrado na, de origem de várias regiões do Brasil a fim de praticar a pecuária. Em Araguaína expandiram-se, de forma ideal, a propriedade privada, a vida dos negócios financeiros e, consequentemente, a exploração da propriedade pelos donos dos meios de produção. Reforça-se que, com a implantação da rodovia BR-153, o desenvolvimento econômico não mais se manteve circunscrito aos limites territoriais "rígidos” de Araguaína (GONÇALVES, 2009).

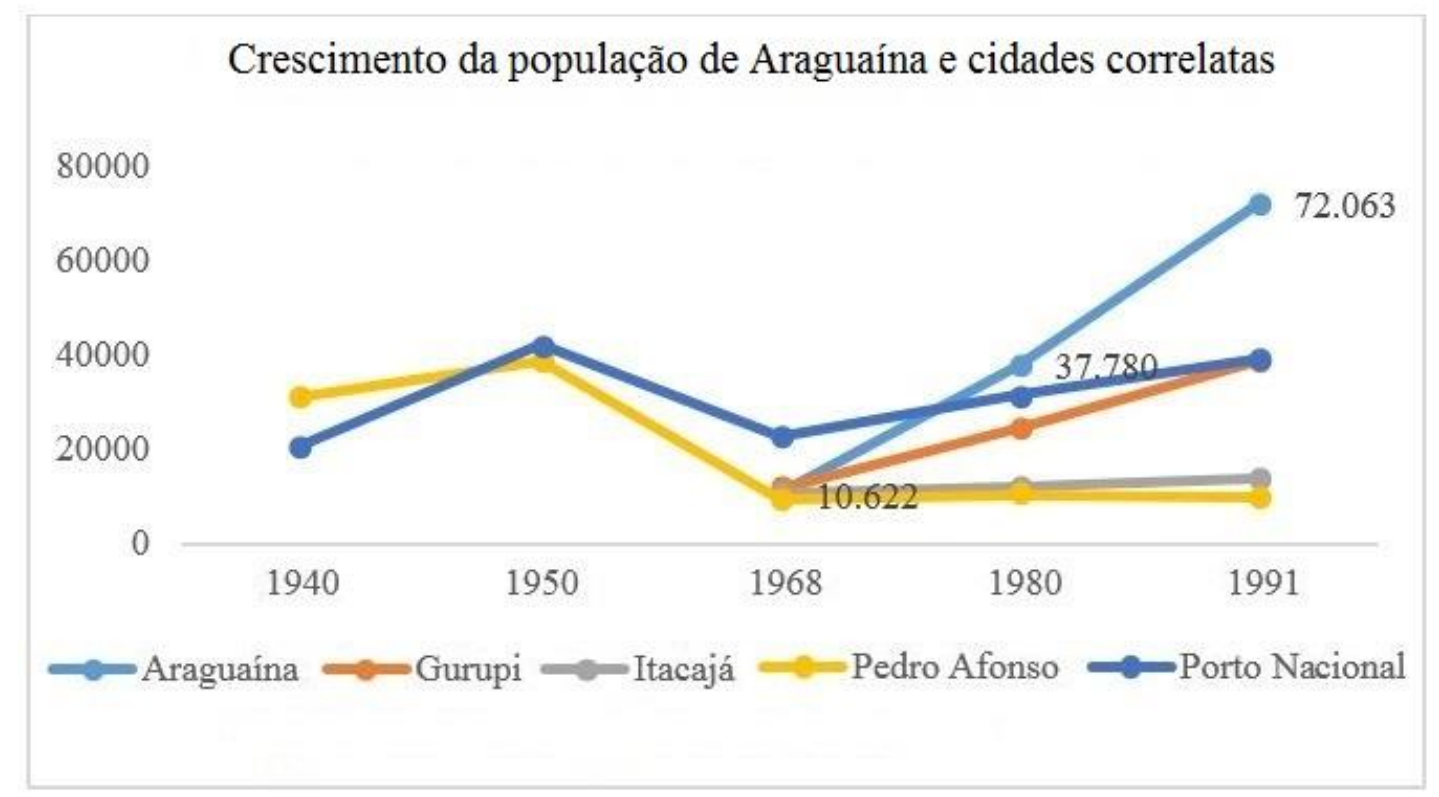

Figura 6.4: Faz referência à população antes e depois da BR-153, de Araguaína e cidades correlatas

Fonte: IBGE (2012, adaptado pelo autor)

Com a promoção de um tráfego mais ágil pela criação da rodovia Transbrasiliana, em Araguaína, houve a intensificação do desenvolvimento no que se refere à qualidade de vida das pessoas promovida pela saúde, educação e renda, representado pelo IDH (Figura 6.5), foram expandidos os espaços da produção econômica por indivíduos, também, como resultante da rodovia. Esse incremento se estende à intensa atividade econômica naquela região que dá subsídios aos transportes, destacando-se várias concessionárias de caminhões, de tratores, veículos de alto luxo, empresas que trabalham com transporte, diversas lojas, oficinas de manutenção de tratores e 
caminhões.

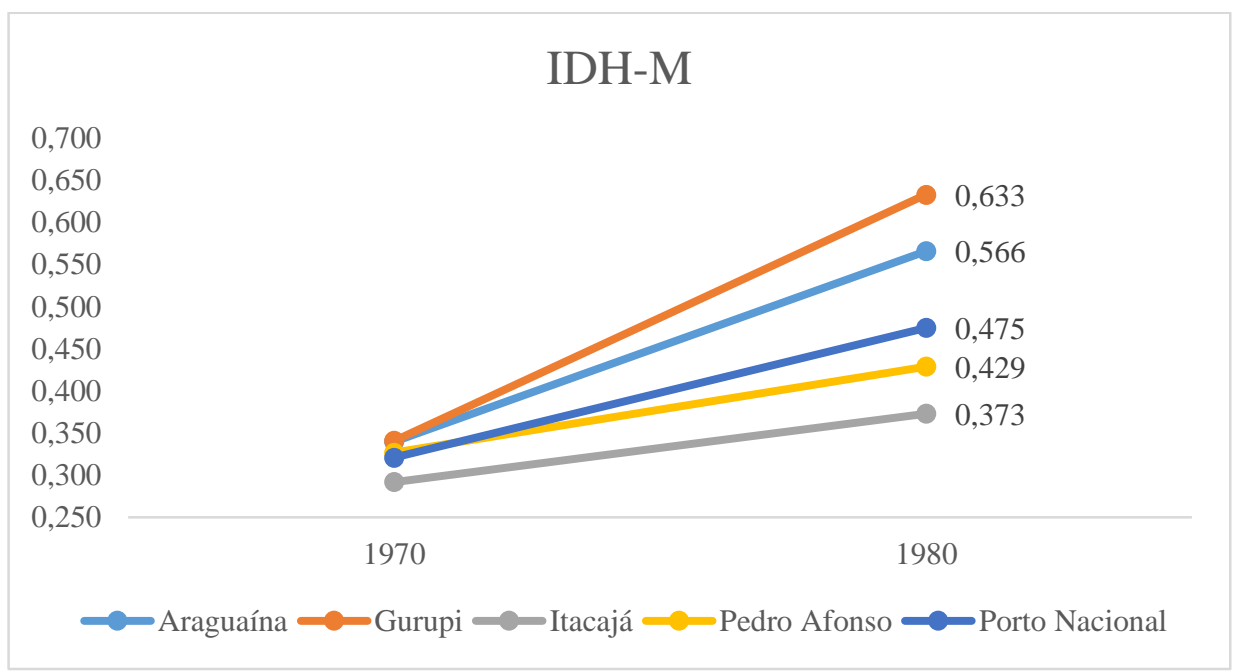

Figura 6.5: Faz referência ao desenvolvimento econômico de antes e depois da BR-153 de Araguaína e cidades correlatas

.Fonte: IBGE (2012, adaptado pelo autor)

Dos impactos da BR 153 em Araguaína resultou o grande fluxo de pessoas e de capitais. Percebese, ainda, nítido impacto na redução dos custos dos transportes para a região.

Ao investigar a história de Araguaína, é possível comprovar que o município possuía precária atividade econômica antes da abertura da rodovia BR-153. Com a BR-153, passou à organização no que tange à distribuição e produção de mercadoria, em especial quando se verificava que a sua rede urbana fora formada. Neste sentido, vale citar as palavras de Ballou (1993): "Sob qualquer ponto de vista-econômico, político e militar, o transporte é, inquestionavelmente, a indústria mais importante do mundo". Beneficiando-se do mesmo entendimento, vislumbra-se Bastidas et al (2001) quando diz que o transporte rodoviário de carga é uma atividade essencial à economia do país.

Evidencia-se, também, os impactos das rodovias na economia interna brasileira devido à essencialidade dos transportes ao plano econômico nacional, afinal o abastecimento dos centros industriais e comerciais depende dos modos de transportes e, principalmente, porque funcionam como estratégias para o crescimento e desenvolvimento econômico e social de uma determinada região.

Freitas (2004) produz amparo literário suficiente ao apresentar pontos positivos do transporte de 
cargas no Brasil:

Em países como o Brasil, com dimensões continentais, o transporte rodoviário apresenta-se como um modo de grande flexibilidade, possibilitando a integração de diferentes e remotas regiões do país. Pode-se destacar que este modo possibilita uma disponibilidade maior para o embarcador, ou seja, sua flexibilidade em termos de tempo e espaço possibilita esta pronta disponibilidade.

Lembrando que o fluxo de transportes não pode ser determinado apenas pelo tempo e espaço, mas também pela conjuntura econômica, aspecto esse que define a implicação direta entre crescimento da economia e condições operacionais dos transportes, especialmente pela melhoria dos acessos aos centros de produção. O fluxo do transporte de carga fica dependente das demandas de mercado, as quais referem-se às diferenças entre o custo e preço, maior oferta do que demanda e, nos casos de efeitos negativos da economia, poder-se-á até incorrer em uma concorrência desigual.

Para melhor confronto da relação feita entre os fatores positivos e negativos do transporte de carga, não apenas os pontos positivos do transporte de cargas devem ser pontuados, conforme amparo literário de Freitas (2004):

As falhas no processo de recuperação das rodovias impedem que o escoamento das cargas seja realizado de forma mais rápida e eficaz prejudicando o desenvolvimento econômico da nação. Outro fator considerável diz respeito à segurança dos usuários que é afetada pela falta de sinalização e conservação em vários trechos das estradas. $\mathrm{O}$ governo disponibiliza recursos para a manutenção das rodovias, no entanto a falta de projetos e planejamentos dificulta a execução das obras.

Ao comparar Araguaína beneficiada com a BR-153 pavimentada, mesmo que, em determinados momentos seu estado de conservação esteja prejudicado, com outro município de aproximadamente mesma idade, sem benefício de rodovia pavimentada, como o caso de Itacajá com a BR-010 sem pavimentação, tem-se em Bonfim (2011) que afirma ser atribuído a Itacajá o isolamento, em face do plano de obras rodoviárias do Estado ou da União, em meio às cidades do nordeste tocantinense, comparar Figura 6.6, em que se verifica que o custo dos transportes em Itacajá é muito superior aos custos das demais cidades . Em que pese à geografia espacial de Itacajá, são disponibilizados praticamente todos os recursos constantes de suas cidades irmãs, menos uma estrada que preste (BONFIM, 2011). 


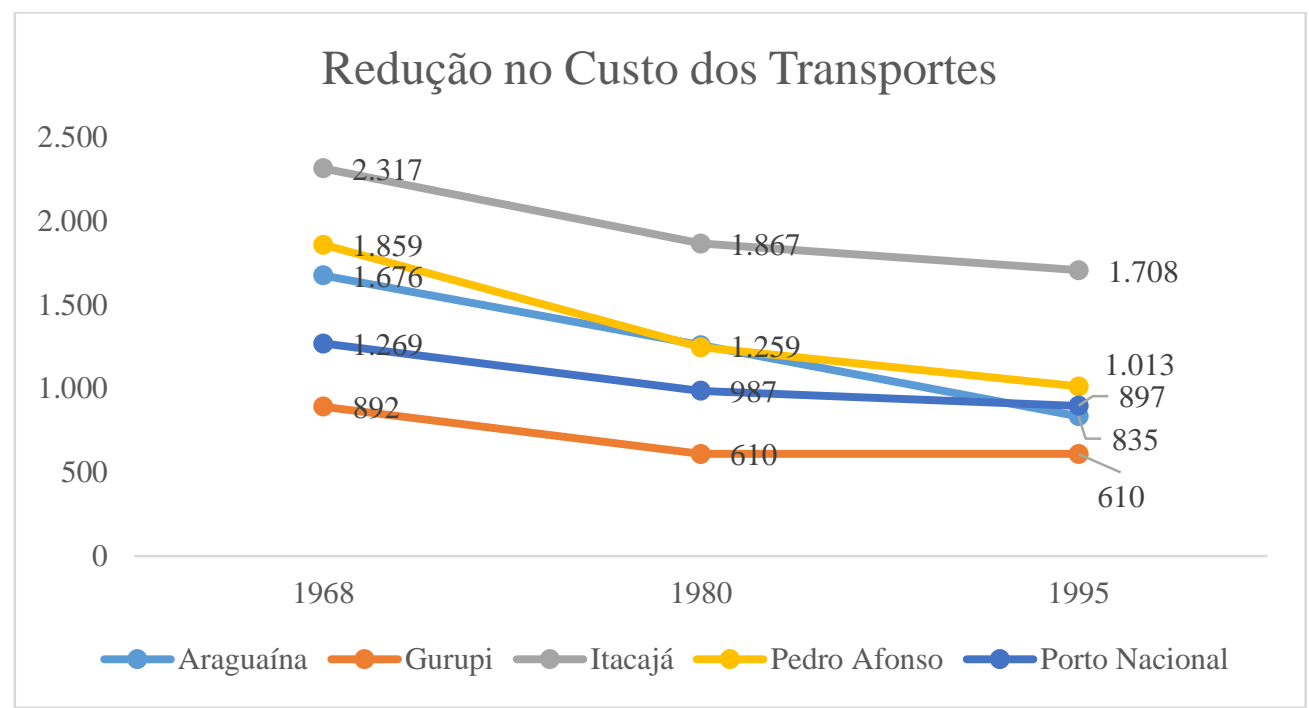

Figura 6.6: Faz referência a redução dos transportes com a melhoria das vias rodoviárias Fonte: IBGE (2012, adaptado pelo autor)

Descreve ainda Bonfim (2011) que os habitantes de Itacajá sentem-se excluídos, visto que há inúmeras dificuldades espaciais para que as pessoas tenham acesso à cidade. De outra forma, há obstáculos no que diz respeito ao estabelecimento de vias de ligação entre Pedro Afonso e Santa Maria/TO. Especificamente o trecho a 50 km de Itacajá como plano Federal da BR-010 e 36 km ao plano Estadual através da TO-239 também não alcançou progresso no âmbito do projeto de rodovias e acessibilidade às demais regiões. Inviabilizou-se a ligação Itacajá e aos demais municípios com vistas a beneficiar escoamento da produção de Itacajá.

\subsubsection{Relação do Crescimento e Desenvolvimento Econômico das cidades às margens versus cidades que estão distantes da rodovia BR-153.}

Do ponto de vista socioeconômico, após a abertura da rodovia BR-153, verifica-se que existem diferenças significativas entre as cidades de Araguaína e Gurupi, as quais foram contempladas com a construção da rodovia BR-153 e Itacajá, Pedro Afonso e Porto Nacional, que ficaram afastadas da rodovia.

Com a finalidade de se apresentar as diferenças encontradas, foram abordados tanto os aspectos do crescimento econômico com base nos setores do PIB, Agropecuária, Indústria e Serviços quanto os do desenvolvimento econômico apresentados nas dimensões do IDH Municipal, Longevidade, Educação e Renda per capita. 
Ao avaliar o PIB Agropecuário de Araguaína e cidades correlatas com base nos dados censitários de 1970 a 1996, a custo de fatores, a nível estadual do IBGE, que usa a estimativa do valor adicionado calculado pela soma do valor da produção e outras receitas menos as despesas de consumo intermediário, é possível constatar-se que, entre os anos de 1959 a 1970, considerados como o auge da construção da BR-153, Araguaína, no ano de 1970, teve um crescimento cinco vezes maior que o ocorrido no ano de 1959.

Embora, em 1970, Araguaína tenha apresentado um expressivo crescimento da agropecuária e valores adicionados muito maiores que os das cidades de Itacajá, Pedro Afonso e Porto Nacional, apresentou valores menores em relação a Gurupi, em torno de $28 \%$. Vale ressaltar que a produção agropecuária de Araguaína, em 1959, era muito menor que a das demais cidades e, em 1970, há praticamente uma inversão de valores, apresentando-se superior a Porto Nacional em torno de $1 \%$ e, em relação a Itacajá e Pedro Afonso, a diferença foi de mais que o dobro.

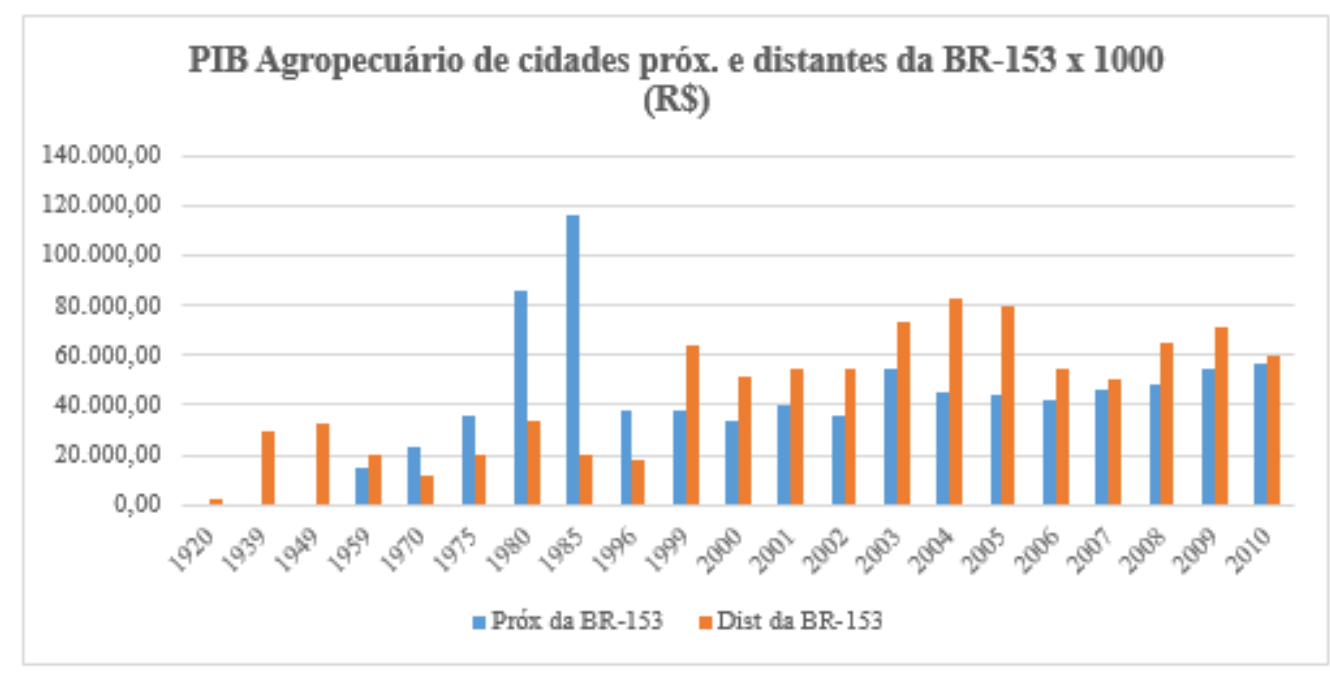

Figura 6.7: PIB Agropecuário de cidades próximas e distantes da BR-153 x 1000 (R\$) Fonte: IBGE (2014, adaptado pelo autor)

Vale ressaltar, ainda, que, conforme Figura 6.7, a soma do PIB Agropecuário em valor agregado das cidades às margens da BR-153, desde o início de sua construção até próximo à criação do estado do Tocantins em 1989, apresenta-se superior ao PIB das cidades afastadas da mesma rodovia. Após a criação do estado do Tocantins, o PIB agropecuário das cidades próximas da rodovia passou a ser menor que o PIB agropecuário das cidades afastadas da BR-153. Uma hipótese 
a ser estudada em outros trabalhos é a de que a criação do estado do Tocantins em 1989 fez com que as cidades afastadas da BR-153 tivessem elevação do PIB.

Das cidades em estudo no presente trabalho, dentre as que foram fundadas na década de 50, apenas Gurupi, no ano de 1959, apresentava PIB industrial, que já estava acima do PIB da bicentenária Porto Nacional, tendo ambas PIBs industriais inferiores ao atingido por Pedro Afonso. Onze anos após, em 1970, Araguaína apresenta PIB industrial em valor agregado de 8.998,47, multiplicado por mil reais, três vezes superior ao de Gurupi, sessenta e nove vezes superior ao de Itacajá, vinte e duas vezes superior ao de Pedro Afonso, que anteriormente possuía PIB superior aos das demais cidades e três vezes superior ao de Porto Nacional. Ressalta-se, ainda, que, quanto ao PIB industrial, Gurupi e Porto Nacional tiveram ganho, Itacajá inexpressivo aumento e Pedro Afonso perda.

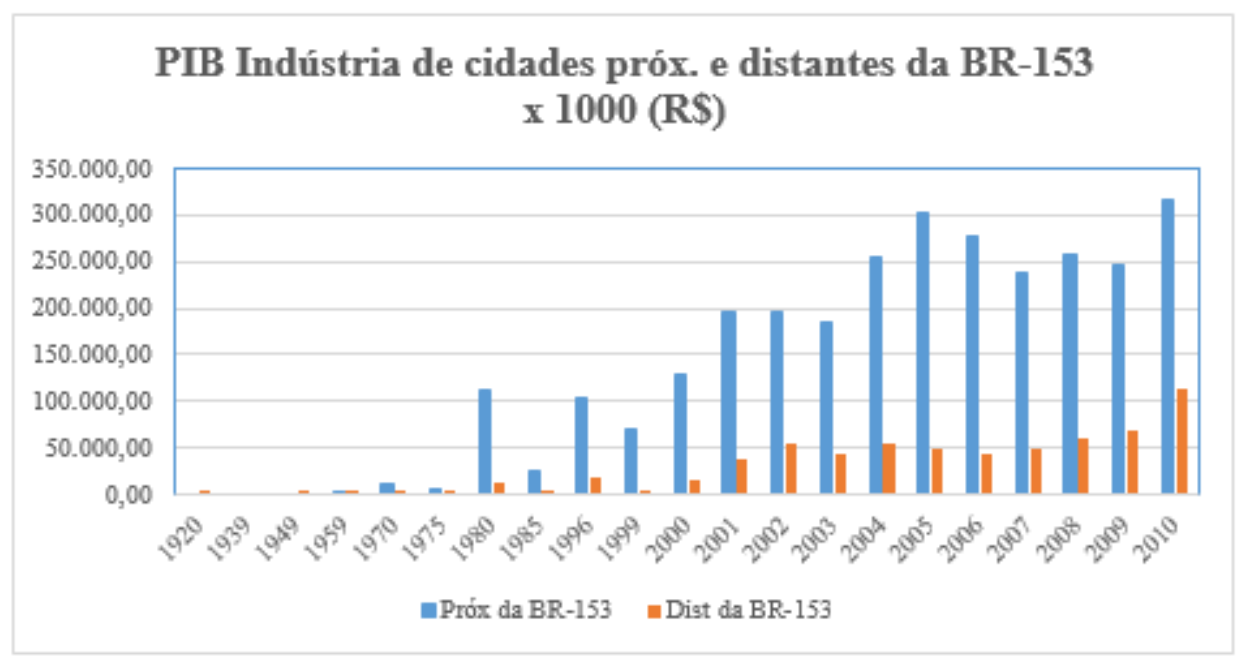

Figura 6.8: PIB Indústria de cidades próximas e distante da BR-153 x 1000 (R \$) Fonte: IBGE (2014, adaptado pelo autor)

Quanto a este setor do PIB, o crescimento da indústria nas cidades que estão às margens da BR153 e nas que estão distantes da rodovia teve um comportamento diferente em relação ao ocorrido com o crescimento da Agropecuária. Enquanto que, na agropecuária houve interseção do valor adicionado no período que compreende a construção da BR-153 e também após a formação do estado Tocantins, no crescimento da indústria, tanto nas cidades às margens da mesma rodovia quanto nas que estão distantes não houve intercessão; as que estão distantes da rodovia tiveram 
crescimento relativamente constante e as que estão próximas da rodovia tiveram crescimento maiores, com sobressaltos e pequenos recuos (Figura 6.8).

Em 1959, o setor de serviços aponta significativas diferenças do valor adicionado entre as cidades; Araguaína apresenta um valor adicionado de 91,53 multiplicado por mil reais, mais de três vezes menor do que Itacajá, que possui o segundo menor valor adicionado e que, até aos dias atuais sofre com baixíssimos índices econômicos, se comparado as demais cidades do estado do Tocantins; Gurupi apresenta o maior valor adicionado entre as cidades em estudo, maior, inclusive, que o de Araguaína quarenta e duas vezes. No ano de 1970 o oposto ocorre, Araguaína passa a ter o maior PIB serviços entre as cidades, sendo superior ao segundo maior PIB serviços em $67 \%$.

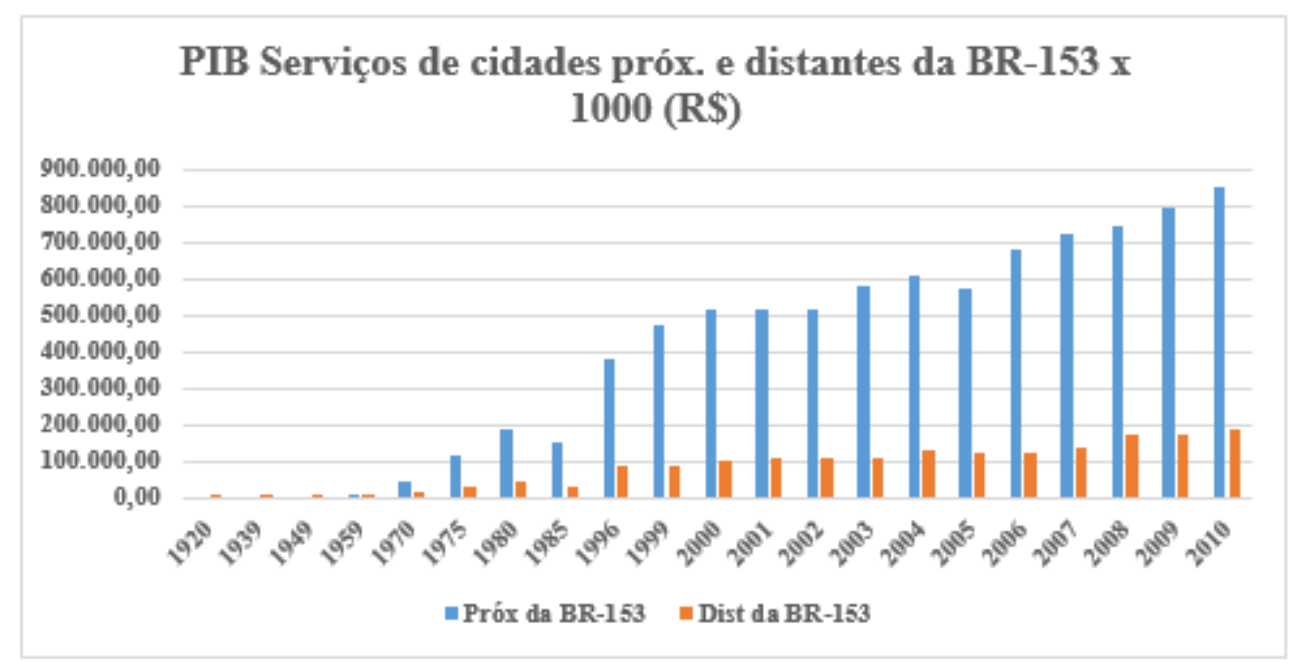

Figura 6.9: PIB Serviços de cidades próximas e distantes da BR-153 x 1000 (R \$) Fonte: IBGE (2014, adaptado pelo autor)

De acordo com a Figura 6.9 o setor de serviços do PIB foi o que mais cresceu entre as cidades que estão às margens da BR-153, com ascensão constante desde 1959 até o último ano apresentado pelo IBGE/IPEA, 2010. Em 1959, as cidades às margens da BR-153 apresentaram PIB Serviços superior em 26\% em relação às cidades distantes da rodovia; em 1970, o PIB serviços foi três vezes maior; em 1975, quatro vezes e em 2010 cinco vezes maior, comparado ao PIB serviços das cidades distantes da BR-153.

Quanto à soma do valor agregado dos setores que compõem o PIB (Agropecuária, Serviços e Indústria) das cidades em estudo, verifica-se que Araguaína, antes do período da construção da BR-153, era a que tinha o menor valor agregado de 1.825,28 multiplicado por mil reais; nos anos 
finais da construção da rodovia, em 1970, apresenta um valor adicionado astronômico de 44.044,92 multiplicado por mil reais, ultrapassando Porto Nacional que, em 1959, tinha um PIB nove vezes superior ao de Araguaína. Gurupi que também está às margens da mesma rodovia, mantém-se na segunda posição de crescimento, enquanto Pedro Afonso e Itacajá tiveram decréscimo de PIB.

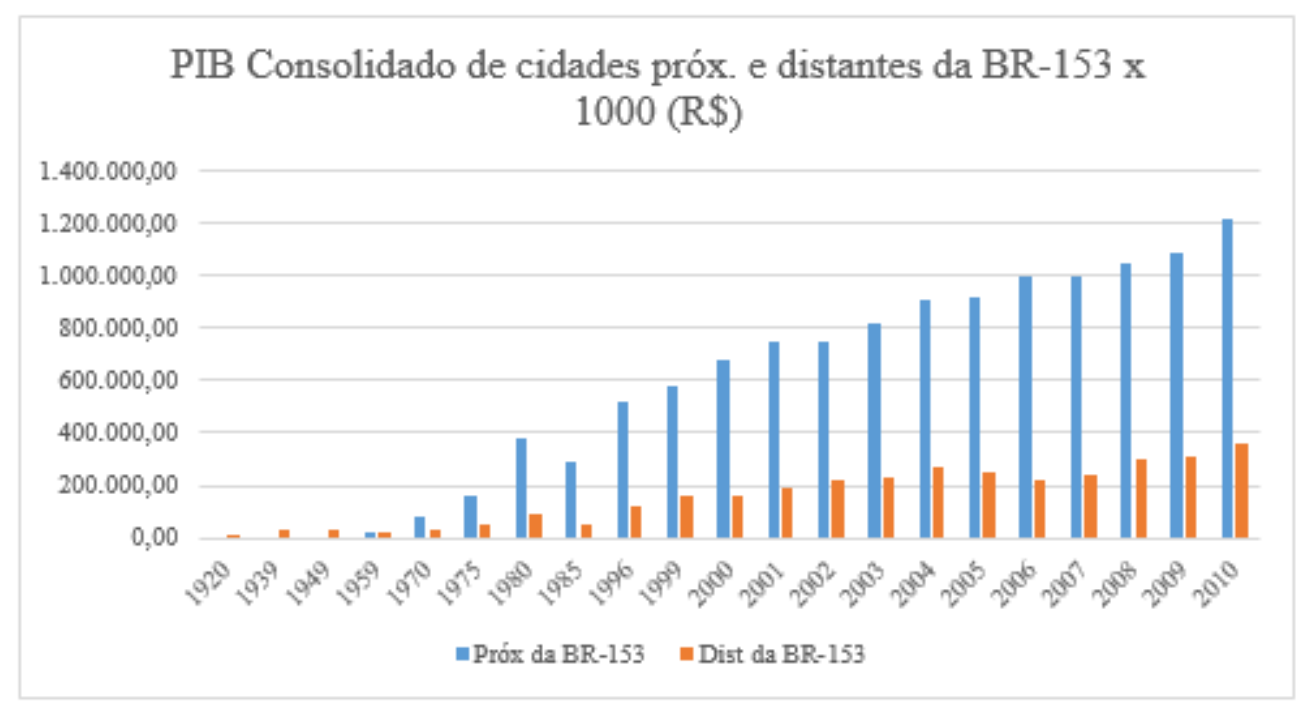

Figura 6.10: PIB Consolidado de cidades próximas e distantes da BR-153 x 1000 (R\$) Fonte: IBGE (2014, adaptado pelo autor)

A Figura 6.10, finaliza a análise com os dados consolidados dos três setores do crescimento econômico expressando que as cidades às margens da BR-153 tiveram ganhos muito superiores em relação às cidades distantes da rodovia, as quais, inclusive, mantiveram um crescimento estável relativamente baixo, se comparado ao crescimento econômico das cidades contempladas com a BR-153.

O IDH dos municípios ou IDHM estudado, que faz referência ao desenvolvimento econômico, não apresentou expressividade de divergências entre as cidades distantes e próximas da BR-153. Apesar do incremento significativo do valor adicionado provocado pelo PIB nas cidades próximas da rodovia BR-153, ele não promoveu significativas diferenças no IDH entre os municípios às margens e afastados da BR-153. Neste sentido vale relembrar que, no caso de Araguaína, onde ocorreu a chegada de um grande número de trabalhadores analfabetos vindos das regiões Norte e Nordeste para trabalhar na construção da BR-153, a dimensão Educação, no ano de 1960, foi afetada negativamente (Figura 6.11). Tal fato dá suporte ao entendimento de que a dimensão 
Longevidade também foi afetada com casos relacionados à violência urbana não sendo possível demandar segurança e números de unidades hospitalares capazes de atender toda procura provocada pelo crescimento físico da cidade, ficando, assim, numa situação mais confortável a Renda per capita provocada pela construção da rodovia.

Em exame da Figura 6.11, verifica-se o comportamento do desenvolvimento humano entre as cidades estudadas e, ao se observar a Tabela 5.7 apresentada no capítulo 5 é possível constatar que Itacajá, Pedro Afonso e Porto Nacional entre os anos de 1960 a 1970, tiveram redução do IDH, ao mesmo tempo Araguaína e Gurupi tiveram aumento do IDH.

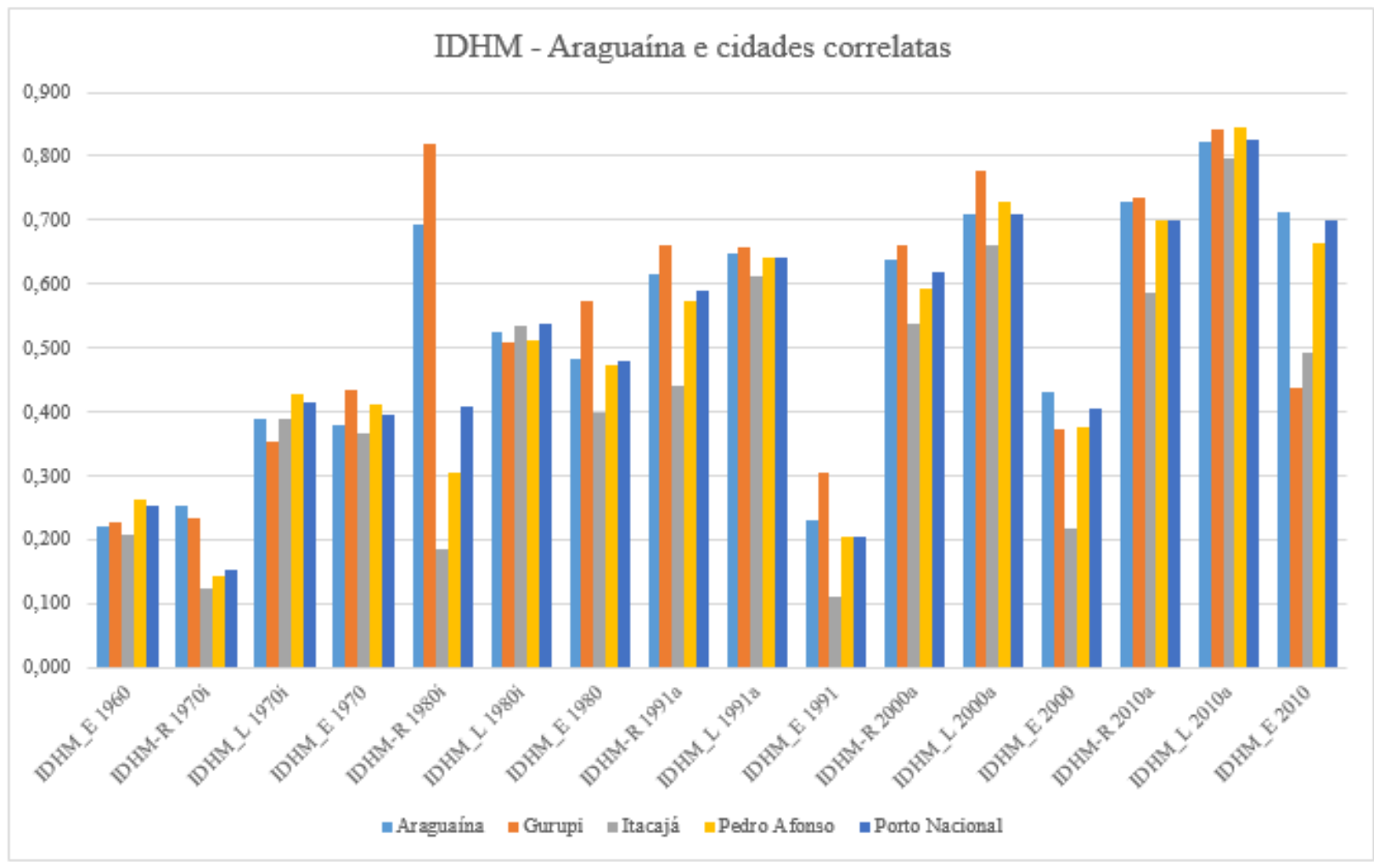

Figura 6.11: IDHM - Araguaína e cidades correlatas Fonte: IBGE (2014, adaptado pelo autor)

Os dados consolidados do IDHM de Araguaína e cidades correlatas expostos na Figura 6.12 demonstram que as cidades distantes da BR-153, no ano de 1970, alcançaram IDHMs superiores aos das cidades próximas desta rodovia. Em 1980 ocorre uma inversão: as cidades às margens da BR-153 ultrapassam as cidades distantes da rodovia e, a partir de 1991, após a criação do estado do Tocantins, ocorrida em 1989, as cidades distantes da rodovia voltam a crescer. Em 2010 o IDHM das cidades distantes da rodovia BR-153 supera o das cidades que estão próximas a ela. 


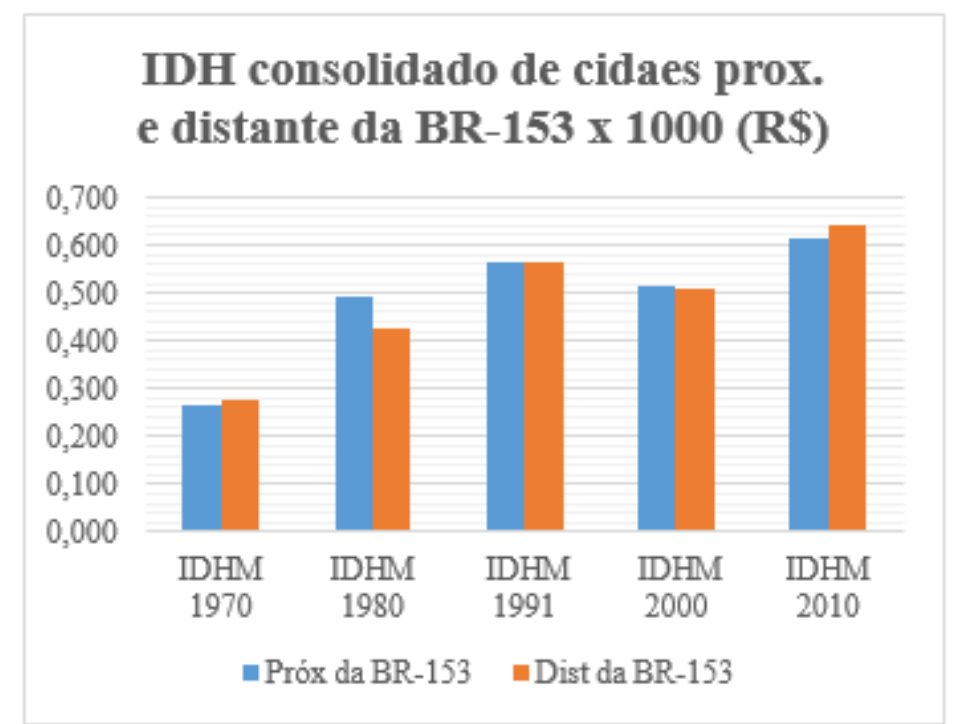

Figura 6.12: IDHM Consolidado de cidades prox. e distantes da BR-153 x 1000 (R\$) Fonte: IBGE (2014, adaptado pelo autor)

Os dados do IDH consolidado das cidades em estudo apresentado na Figura 6.12 foram separados em dois grupos, quais sejam: o das cidades mais próximas da rodovia federal BR-153 composto por Araguaína e Gurupi e o grupo de cidades que estão afastadas da mesma rodovia, composto pelas cidades de Itacajá, Pedro Afonso e Porto Nacional. Através do dados e gráficos apresentados, torna-se possível constatar alterações no comportamento dos distintos grupos do IDHM nos períodos coincidentes com a construção da rodovia BR-153 e a partir da inclusão das cidades ao novo estado do Tocantins. 


\section{CONCLUSÕES E RECOMENDAÇÕES}

"O choro pode durar uma noite; pela manhã, porém, vem o cântico de júbilo...”

(Salmos 30:5)

A construção da presente dissertação teve como objetivo avaliar a influência da rodovia BR-153 no crescimento e desenvolvimento de Araguaína, comparar alguns índices socioeconômicos da cidade de Araguaína, no Estado do Tocantins e fazer a relação do crescimento de Araguaína, antes e depois da construção da rodovia BR-153, com o intuito de demonstrar que a implantação da BR153 foi fundamental para o desenvolvimento e crescimento da cidade de Araguaína.

Araguaína atraiu volumoso contingente populacional, a partir do ano de 1960, e passou, em meio século, de pequeno povoado para o tamanho de grande cidade para o Estado do Tocantins, mais que isto, apresentou-se com rápidas e intensas transformações socioeconômicas. Desse acontecimento, emergiram as seguintes questões: Qual a importância da rodovia BR-153 para o crescimento e desenvolvimento econômico de Araguaína? O que mudou no município de Araguaína e na vida das pessoas após a pavimentação da rodovia BR-153?

A rodovia BR-153 fez com que a cidade de Araguaína crescesse exorbitantemente em relação às demais cidades próximas, que eram maiores e mais antigas que ela. A mobilidade foi expandida, visto que a partir da facilidade do fluxo de transportes, os setores econômicos, serviços, indústrias e comércios foram pontos-chave para melhor articulação espacial regional intra-estadual e interestadual. Esta mesma mobilidade ocasionada pelo facilitado transporte, através da rodovia BR-153, elevou o número de habitantes, onde nordestinos especialmente dos Estados de Maranhão e Piauí, deixaram suas cidades de origem e ali estabeleceram residências gerando as transformações espaciais na cidade de Araguaína. Conforme dados cedidos pelo IBGE, a explosão da população ocorreu entre os anos de 1960 a 2010, passando de 10.826 para 150.484 habitantes.

Quando da criação do município de Araguaína, a economia tinha como base a produção de babaçu, seguida da produção de arroz, amendoim e algodão. Com a construção da rodovia BR-153, Araguaína passou a ser um importante acesso ao extremo norte do então Estado de Goiás, por sua 
posição geográfica, transformando-se num importante elo entre Norte e Nordeste. Com isso, começou a alcançar notoriedade econômica na região, tendo como fatores desencadeadores do crescimento econômico a expansão das atividades agropecuária, indústria, comércio e serviços.

Nesse sentido até os anos de 1950, a agricultura e a pecuária eram de subsistência para atender a necessidade da população da cidade, onde poucas terras eram ocupadas para tal finalidade. Após a construção da rodovia Transbrasiliana houve um incremento astronômico da ocupação das terras para a criação de gado de corte e produção de laticínios.

Em relação ao setor industrial, em 1965, foi criada em Araguaína a indústria da Região Norte Companhia Industrial e Mercantil da Bacia Amazônica (CIMBA) e, em 1967 foi criado o primeiro frigorífico de Araguaína, de propriedade do Grupo Boa Sorte, que além de atender a região, exporta seus cortes para outros países. Houve um grande crescimento da atividade pecuarista e por este motivo a cidade é conhecida como "Capital do Boi Gordo”.

Apesar de ser uma referência da pecuária regional, o setor de comércio e serviços de Araguaína concentra o maior volume de recursos econômicos. Boa parte do comércio se destina a insumos primários, máquinas e implementos agrícolas e pecuários. No senso de 1960 a cidade possuía apenas três unidades de serviços, cinco anos mais tarde, quando a abertura da Transbrasiliana com pavimentação fora concluída, há um incremento de mais $200 \%$ de serviços, compostos por transporte e comunicação, intermediação financeira, administração pública, aluguéis e outros.

Um dos fortes elementos que reflete na economia, a partir da construção da rodovia BR-153 é o movimento de mercadorias, pois as principais vias de circulação do município passaram a se conectar com as rodovias. Desse modo, esses eixos de circulação e, portanto, de ligação regional, passaram a atuar para além da função eminentemente urbana. $\mathrm{O}$ consumo de bens e serviços diversos foi expandido às demais regiões do país, graças à pavimentação da rodovia BR-153, que a partir de então, iniciou processo de passagem de migrantes, além de receber e distribuir produtos industriais transportados em caminhões desde o Sul ao Norte do país e vice-versa.

Vê-se que houve, principalmente, um incremento na economia, com base na apuração do PIB no período tendo em vista a necessidade de investimentos, tanto pelo governo, quanto por indústrias que se instalaram no local, além da maciça prestação de serviços. Verificou-se que antes da 
pavimentação da BR 153 este índice econômico de Araguaína chegou a ser menor que o da cidade de Itacajá, posteriormente apresentou um aumento substancial em 1970 e expõe um crescimento acima de $2.300 \%$ em relação ao ano de 1959. Atualmente, o PIB do município de Araguaína representa em torno de $11 \%$ de participação no Estado do Tocantins, mantendo sua economia em constante crescimento. Atingindo o empreendedorismo municipal, onde o crescimento médio anual é de $15 \%$ tal como o do Estado. A taxa de sobrevivência de empresas após a abertura ultrapassa percentuais até mesmo da capital Palmas, entre as razões destaca-se incentivos dados pela prefeitura com o Programa Minha Empresa Minha Vida, seguido de um pacote de projetos de lei lançados em 2013.

Diante das mudanças ocorridas na cidade de Araguaína após a construção da Rodovia Transbrasiliana, indo desde o aumento do tamanho geográfico, crescimento populacional, acréscimo do consumo de bens e serviços, ampliação da produção agropecuária, incidindo em um maior PIB desde os anos de 1960 até os dias de hoje, tornando-se um significativo índice econômico para o Estado do Tocantins, fica evidente que a vida dos moradores da cidade mudou após a pavimentação da rodovia 153 e, de acordo com o Índice de Desenvolvimento Humano IDH, é possível verificar um crescimento na renda, melhorias na educação e em aspectos relacionados à longevidade da população.

Nos aportes históricos consultados constam dados de que a cidade expandiu-se de forma anormal em razão de que, no princípio da construção do espaço territorial o tipo de arranjo eram as favelas. Dessa descrição histórica e forma de arranjo populacional, vê-se que a precariedade era devido à falta de incentivo governamental, em especial da ausência de infraestrutura na área de mobilidade urbana, o que é afeto à malha rodoviária.

Antes da criação do Estado do Tocantins e da construção da Rodovia Transbrasiliana, a região norte do estado de Goiás era uma região esquecida e distante do desenvolvimento existente no sul do Estado e na maioria dos outros estados brasileiros. Com isso, a população sofria com o baixo desenvolvimento humano, alto índice de analfabetismo, renda muito inferior à renda do sul de Goiás, poucas cidades com sistema de abastecimento de água pluvial e sem tratamento, baixa expectativa de vida ao nascer, maioria das rodovias de interligação entre as cidades eram sem pavimentação e as cidades não possuíam ruas calçadas. 
Devido ao crescimento populacional, passou-se a ter uma preocupação política quanto ao bem estar social que interferiu nas ações de combate às enfermidades. Mostra disso foi que em 1972, católicos oronitas instalaram o primeiro hospital do município. Aliado a isso, houve uma redução nos índices de internação por doenças infecciosas e parasitárias. Atualmente, quanto a assistência à saúde, no que diz respeito ao número de ambulatórios somados a postos, centros e unidades básicas de saúde, pode-se constatar pelos dados apresentados neste trabalho que a cobertura da rede privada é superior à pública pelo fato desta investir efetivamente mais recursos em suas unidades.

Observa-se ainda, que após a construção da rodovia Transbrasiliana e por quase duas décadas houve um aumento da qualidade do serviço de saneamento ambiental. Cabe destacar aqui que, quanto ao sistema de rede pública de abastecimento de água, apesar do aumento da população, teve seu percentual inalterado entre os anos de 1998 e 2013. Outro elemento a ser observado é a coleta de lixo urbano, que em Araguaína apresenta índices de destaque em relação aos percentuais a nível nacional.

Ainda em relação ao aspecto longevidade, no ano de 1970, a expectativa de vida de Araguaína encontrava-se abaixo da média do estado com 48,36 anos, abaixo inclusive de cidades como Pedro Afonso e Porto Nacional; nos 5 anos que se seguiram após o término da pavimentação da rodovia, constatou-se uma melhora na expectativa de vida atingindo uma média de 56,49 anos.

No que diz respeito à educação, dimensão integrante do Índice de Desenvolvimento Humano (IDH), mesmo com as políticas governamentais para redução do analfabetismo ocasionado pelo aumento de trabalhadores braçais vindos de outras regiões para trabalhar na construção da rodovia BR-153, e também para tentar a sorte nesta nova fronteira agrícola, Araguaína apresentou no ano de 1960 uma taxa de analfabetismo de 60\%, taxa essa considerada altíssima entre pessoas com 15 anos e mais, em uma população de 9.103 habitantes conforme fontes pesquisadas. Nos anos subsequentes, com a implementação de recursos governamentais, percebe-se a diminuição do analfabetismo em decorrência dos investimentos empregados na cidade.

Quanto ao elemento renda, no período de 1970 a 1980, é possível notar o aumento desta dimensão do IDH de 0,252 para o patamar de 0,693. Pode-se inferir que a renda do município era excessivamente baixa ou pouco existia renda formal e, com o deslocamento de pessoas para trabalhar na construção da BR-153, passou a existir mais rendas formais. 
Diante do exposto anteriormente, conclui-se que a construção da rodovia BR-153 foi extremamente importante para o crescimento e desenvolvimento econômico de Araguaína, pois trouxe melhorias na condição de vida das pessoas fazendo com que os índices Longevidade, Educação e Renda tivessem aumentos significativos, por conta da quantidade de empregos gerados, investimentos governamentais em políticas públicas, além do desenvolvimento da agropecuária e indústria, bem como a expansão das oportunidades de emprego, gerando renda e aumentando o capital regional com melhoria da riqueza do município.

Aliado às melhorias constatadas, verificou-se os seguintes aspectos que mudaram na vida dos habitantes de Araguaína, após a pavimentação da rodovia Transbrasiliana: influência econômica e política de ordem regional, nacional e mundial, através do intenso processo de urbanização; regionalização econômica, populacional e política, maior acesso à economia de outros Estados, sobretudo maior gama de investimento de capital.

\subsection{IMPORTÂNCIA E RECOMENDAÇÕES PARA TRABALHOS FUTUROS}

No decorrer do tempo deste trabalho, foi possível identificar algumas possibilidades de estudos, de pontos que, na medida em que as condições permitirem, poderão ser desdobrados. Portanto, sugerese a seguir algumas recomendações para trabalhos futuros relacionados ao tema em questão:

- É servir como subsídio para estudos relacionados aos transportes e a economia de um determinado munícipio, bem como subsidiar a políticas do governo no caso de planejamento de transportes na elaboração de que faça com que uma região se desenvolva sem prejudicar outras.

- Estudos das discrepâncias com perdas econômicas provocadas dentro de uma mesma região por construção de rodovias e, levantar dados capazes de identificar e propor ações que evitem tais situações

- Investigação e análise das alterações provocadas no espaço urbano das cidades atendidas por pátio multimodal da ferrovia Norte-Sul nos municípios tocantinenses comparando com outros centros urbanos que a mais tempo é atendido com este modal de transporte.

- Como um planejamento bem feito pode favorecer o crescimento e desenvolvimento de forma homogênea

- Recomendo estudos com maior profundidade dos casos Pedro Afonso e Porto Nacional se a BR153 foi vetor do declínio econômico ocorrido no período de sua construção. 


\subsection{Limitações}

\subsubsection{Cunho material}

Para consolidação mais apurada dos dados estatísticos num estudo temporal, torna-se necessário que as variáveis sejam coincidentes no tempo e, para o estudo em tela, embora suficientes, poucos foram os anos em que o PIB e o IDH apresentaram coincidência de dados.

A localização e disponibilidade de material de estudos nos sítios eletrônicos foi outro fator que dificultou o levantamento de dados. Houve instantes em que determinados dados estavam disponíveis em endereço de sítios eletrônicos do governo e, ao retornar aos dados, estes tinham mudado de endereço dentro do próprio sitio ou estavam indisponível.

Pelo fato de Araguaína ter sido emancipada pouco antes da construção da rodovia BR-153, não foi possível o levantamento de dados socioeconômicos de pelo menos cinco anos antes da construção da rodovia. Parte dos dados levantados da cidade coincidem com o início ou após o início da construção da rodovia.

Confusões feitas nas denominações dadas à BR-153, Transbrasiliana e Belém-Brasília, pelos autores que escreveram sobre a BR-153. Muitos são os autores que usam os referidos nomes para tratar da mesma rodovia, inclusive o próprio governo nos Planos Rodoviários Nacionais, entretanto, cumpre salientar que são rodovias distintas, uma a BR-153 e a outra é a BR-010.

\subsubsection{Cunho Pessoal}

Conciliar o tempo de estudos e pesquisa numa universidade pública, onde as aulas são ministradas no período matutino e vespertino, com trabalho numa empresa privada. 


\section{REFERÊNCIAS}

ACIARA. Portal eletrônico. 2014. Taxa de sobrevivência de empresas em Araguaína é a maior do TO. Disponível em: <http://portalaciara.com.br/taxa-de-sobrevivencia-de-empresas-emaraguaina-e-a-maior-do-to/> . Acesso em: 13 de fevereiro de 2015.

ALBANO, J.F. Efeitos dos excessos de cargas sobre a durabilidade de pavimentos. Tese de doutorado. Universidade Federal do Rio Grande do Sul. Porto Alegre, 2005.

ALMEIDA, C. F. Elaboração de Rede de Transporte Multimodal de Carga para a Região Amazônica sob o Enfoque de Desenvolvimento Econômico. 2008. $251 \mathrm{f}$. Tese de Doutorado em Transportes - Departamento de Engenharia Civil e Ambiental, Universidade de Brasília - UNB, Brasília-DF.

ANDRADE, C.; CORDOVIL, F. A cidade de Maringá, pr. O plano inicial e as "requalificações urbanas". Scripta Nova Revista Electrónica de Geografía Y Ciencias Sociales. Disponível em: <http://www.ub.edu/geocrit/-xcol/55.htm>. Acesso em 16 de janeiro de 2014.

ANSOFF, H. I. A nova estratégia empresarial. 2.ed. São Paulo: Atlas, 1993.

AQUINO, N.A. A Construção da Belém-Brasília e suas Implicações no Processo de Urbanização do Estado do Tocantins. In: GIRALDIN, O. A (Trans)Formação do estado do Tocantins. Goiânia: UFG, 2002.

ASCOM. Notícias. Prefeitura de Araguaína, Araguaína, 20 maio 2013. Disponível em: <http://www.araguaina.to.gov.br/portal/paginas.php?p=not\&not=noticias\&id=9>. Acesso em: 14 de novembro de 2013.

BADER, P. Instituto Goethe, 28 mar 2008. Disponível em: <http://www.goethe.de/ges/umw/dos/nac/den/pt3106180.htm>. Acesso em: 14 de março de 2014.

BALlOU, R. H. Logística Empresarial - Transportes, Administração de Materiais e Distribuição Física. São Paulo: Atlas, 1993.

BARAT, J. A Evolução dos Transportes no Brasil. Rio de Janeiro: Fundação Instituto Brasileiro de Geografia e Estatística: Instituto de Planejamento Econômico e Social, 1978.

. Transporte e industrialização no Brasil no período de 1885-1985: o caso da indústria siderúrgica (Vol. 279). Rio de Janeiro: Biblioteca do Exército Editora, 1991.

. Logística, transporte e desenvolvimento econômico: a visão macroeconômica. São Paulo: CLA Cultural Ltda., 2007.

BARRO, R. J.; SALA-I-MARTIN, X. Economic Growth. 2.ed. Massachusetts, The MIT Press, 2004.

BASTIDAS, G. N. et. al. Uso do QFD no Setor de Serviços: Avaliação de uma Transportadora Rodoviária de Carga. In: Enegep - Encontro Nacional de Engenharia de Produção. 21. 2001. Salvador. Anais... Salvador, 2001.

BCB, B. INDECO - Indicadores Econômicos Consolidados. Disponível em: <https://www.bcb.gov.br/?INDECO>. Acesso em 26 janeiro de 2014.

BECKER, Berta K. Amazônia. São Paulo, 1991. 
BONFIM, C. B. Rememorando Itacajá. Goiânia: Kelps, 2011.

BRASIL. Ato das Disposições Constitucionais Transitórias. Diário Oficial da União, Brasília, 05 de outubro de $1988 . \quad$ Disponível em: <http://www.planalto.gov.br/ccivil_03/constituicao/constituicao.htm\#adct>. Acesso em 12 de fevereiro de 2014.

BRASIL. Decreto Lei n. 200 de 25 de fevereiro de 1967. Dispõe sobre a organização da Administração Federal, estabelece diretrizes para a Reforma Administrativa e dá outras providências. Diário Oficial da União, Brasília, 27 de fevereiro de 1967. Disponível em: <http://www.planalto.gov.br/ccivil_03/decreto-lei/del0200.htm>. Acesso em 22 de fevereiro de 2014.

BRASIL. Decreto n. 862 de 16 de outubro de 1890. Concede privilegio, garantia de juros e mais favores para o estabelecimento de um systema de viação geral ligando diversos Estados da União á Capital Federal. Coleção de Leis do Brasil de 1890, Rio de Janeiro, 16 de outubro de 1890. Disponível em: <http://www2.camara.leg.br/legin/fed/decret/1824-1899/decreto-862-16-outubro1890-523759-publicacaooriginal-1-pe.html>. Acesso em: 30 de janeiro de 2014.

BRASIL. Decreto n. 5.141 de 5 de janeiro de 1927. Cria o Fundo Especial para Construção e Conservação de Estradas de Rodagem Federais, constituído por um adicional aos impostos de importação para consumo a que estão sujeitos: gasolina, automóveis, auto-ônibus, auto caminhões, chassis para automóveis, pneumáticos, câmaras de ar, rodas maciças, motocicletas, bicicletas, sidecar e acessórios para automóveis, e dá outras providencias. Diário Oficial da República Federativa do Brasil, Rio de Janeiro, 5 jan.1927. Disponível em: $<$ http://legis.senado.gov.br/legislacao/ListaNormas.action?numero=5141\&tipo_norma=DEC\&dat $\mathrm{a}=19270105$ \&link=s $>$. Acesso em: 04 de fevereiro de 2014.

BRASIL. Decreto n. 8.324 de 7 de outubro de 1910. Aprova o regulamento para o serviço subvencionado de transportes por automóveis. Diário Oficial da República Federativa do Brasil, Rio de Janeiro, 28 out $1910 . \quad$ Disponível em: http://legis.senado.gov.br/legislacao/ListaTextoIntegral.action?id=42474\&norma=58210. Acesso em: 05 de fevereiro de 2014.

BRASIL. Decreto n. 24.497 de 29 de junho de 1934. Aprova o plano geral de viação nacional e dá outras providências. Diário Oficial da República Federativa do Brasil, Rio de Janeiro, 30 junho de $1934 . \quad$ Disponível em: <http://legis.senado.gov.br/legislacao/ListaTextoIntegral.action?id=13557\&norma=28357>. Acesso em: 10 de fevereiro de 2014.

BRASIL. Lei $\mathrm{n}^{\circ} 801$ de $1^{\circ}$ dezembro de 1887. Criação da Vila Pedro Afonso. Diário Oficial do Estado de Goiás. Goiânia, 28 out 1910. http://www.casacivil.go.gov.br/post/ver/155258/criacaodos-municipios>. Acesso em 07 de fevereiro 2013.

BRASIL. Lei n. 4.592 de 29 de dezembro de 1964. Aprova o Plano Nacional de Viação. Diário Oficial da União, Brasília, 30 de dezembro de 1964. Disponível em: < http://www.planalto.gov.br/ccivil_03/leis/1950-1969/L4592.htm.>. Acesso em: 22 de fevereiro de 2014.

BRASIL. Lei n. 5.173 de 27 de outubro de 1966. Dispõe sobre o Plano de Valorização Econômica da Amazônia; extingue a Superintendência do Plano de Valorização Econômica da Amazônia (SPVEA), cria a Superintendência do Desenvolvimento da Amazônia (SUDAM), e dá outras 
providências. Diário Oficial da União, Brasília 28 de outubro de 1966. Disponível em: < http://www.planalto.gov.br/ccivil_03/leis/L5173.htm>. Acesso em: 24 de março de 2014.

BRASIL. Ministério da Agricultura. Economia e Emprego, 28 fevereiro de 2014. Disponível em: <http://www.brasil.gov.br/economia-e-emprego/2014/02/agropecuaria-permanece-entredestaque-do-pib-brasileiro>. Acesso em: 22 de abril de 2014.

BRASIL. Ministério do Trabalho e Emprego. Trabalho escravo no Brasil em retrospectiva: referências para estudos e pesquisas. Jan 2012. Disponível em: <http://portal.mte.gov.br/data/files/8A7C816A350AC882013543FDF74540AB/retrospec_trab_es cravo.pdf $>$. Acesso em: 20 de maio de 2014.

BRASIL. Ministério dos Transportes - Conselho Nacional de Transportes. Plano Nacional de Viação. Rio de Janeiro: 1973.

BRASIL. Ministério dos Transportes. Plano Nacional de Viação: Conferência para a Associação dos Diplomados da Escola Superior de Guerra - Delegacia de Juiz de Fora. Juiz de Fora, 1973.

BRASIL. Ministério dos Transportes - Conselho Nacional de Transportes. Planos de Viação Evolução Histórica (1808 - 1973). Rio de Janeiro: Cia. Brasileira de Artes Gráficas, 1974.

BRASIL.M.D., BARBOSA, R.A. Plano Nacional de Viação: Conferência para a Associação dos Diplomados da Escola Superior de Guerra - Delegacia de Juiz de Fora. Juiz de Fora, 1976.

BRASILEIRO, A.et al. Transportes no Brasil: história e reflexões. Recife: Editora Universitária da UFPE, 2001.

BRITO, E. P. O papel de Palmas - TO na rede de integração regional. Faculdade de Ciências Humanas. Dourados, MS: Universidade Federal da Grande Dourados, 2009.

BRUNO, A. Araguaína - Cidade Orionita, 30 de janeiro de 2008. Disponível em: <http://www.orionitas.com.br/destaques_orionitas_araguana.php>. Acesso em: 13 de julho de 2014.

CNC - Confederação Nacional do Comércio de Bens, Serviços e Turismo. Estatísticas. Disponível em: 〈http://empresometro.cnc.org.br/Estatisticas〉. Acesso em 25 de março de 2015.

CNES, C. Arquivos Completos, Módulo Download, 23 de dezembro 2009. Disponível em: <http://cnes.datasus.gov.br/Mod_Arquivos_Completos_Brasil.asp>. Acesso em: 17 de março de 2014.

CNT - Confederação Nacional do Transporte. Pesquisa rodoviária 2006: Relatório gerencial. Disponível em:<http://www.cnt.org.br>. Acesso em: 23 de janeiro de 2014.

CORREIA, P. S. Abrindo os arquivos. Goiânia: Kelps, (2001).

DAMÁSIO, B. Centro de Estudos sobre África, Ásia e América Latina, 31 de dezembro de 2013. Disponível em: <http://pascal.iseg.utl.pt/ cesa/index.php/dicionario-da-cooperacao/Glossary1/\%C3\%8D/\%C3\%8Dndice-de-Desenvolvimento-Humano-(IDH)-261/>. Acesso em: 28 de fevereiro de 2014.

DATASUS, T.; IBGE. Indicadores de Saúde e Pactuações. Disponível em: <http://www2.datasus.gov.br/DATASUS/index.php?area=0201>. Acesso em: 14 de março de 2014. 
DATASUS, T.; IBGE. Indicadores populacionais e de saúde. 12 nov 2013. Disponível em: <http://tabnet.datasus.gov.br/cgi/deftohtm.exe?ibge/censo/cnv/alfto.def>. Acesso em: 12 de novembro de 2013.

DATASUS, T.; IBGE. Índice demográfico $e$ socioeconômico. Disponível em: <http://www2.datasus.gov.br/DATASUS/index.php?area=0206>. Acesso em: 14 de março de 2014.

DIAS, J.; DIAS, m.h.a. Crescimento Econômico e as Políticas de Distribuição de Renda e Investimento em Educação nos Estados Brasileiros: Teoria e Análise Econométrica. Estudo Econ., 2007. Disponível em: <http://www.scielo.br/pdf/ee/v37n4/a01v37n4.pdf>. Acesso em 10 de outubro de 2013.

DIAS, S.; BRITO, E. Uma análise territorial da rodovia Belém-Brasília em Araguaína-TO. Revista Tocantinense de Geografia, 80-92, jul - dez 2012. Disponível em: <http://www.revista.uft.edu.br/index.php/geografia/article/viewFile/533/pdf>. Acesso em: 20 de dezembro de 2013.

DIMAS, J. Revista Científica do ITPAC, 30 out 2009. Disponível em: <http://www.itpac.br/arquivos/Revista/24/7.pdf>. Acesso em: 25 de março de 2014.

DINIZ, C. C., \& CROCCO, M. Economia Regional e Urbana. Belo Horizonte: Editora UFMG, 2006.

DNIT. Portal eletrônico - Mapa Condições das Rodovias, 2011. Disponível em: <http://www2.transportes.gov.br/bit/02-rodo/4-cond-rodo/to.pdf>. Acesso em: 10 de junho de 2014.

FACDO, F. Faculdade Dom Orione, 09 fev 2014. Disponível em: <http://www.catolicaorione.edu.br/portal/> . Acesso em: 09 de fevereiro de 2014.

FARIAS, P.; ALMEIDA, D. A problemática da formação do espaço urbano do município de Araguaína/TO. XVI Encontro Nacional dos Geógrafos. Porto Alegre, 2010.

FIRMINO, A. C., \& WRIGHT, C. L. Financiamento do Setor de Transporte no Brasil. Washington: IDB Bookstore, 2001.

FREITAS, M. B. Transporte Rodoviário de Cargas e sua Respectiva Responsabilidade Civil. Jus Navigandi, 17 maio 2004. Disponível em: < http://jus2.uol.com.br/doutrina/texto.asp?id=5231>. Acesso em: 01 de fevereiro de 2014.

FROMM, G. Transportes e desenvolvimento econômico. Tradução de Sylvia de S. Jatobá e Vera Jatahy. 1. ed. Rio de Janeiro: Victor Publicações, 1968.

FURTADO, C. Formação econômica do Brasil .2. ed. São Paulo: Editora Nacional, 1975.

GALVÃO, O. J. Desenvolvimento dos transportes e a integração regional do Brasil: uma perspectiva histórica. Planejamento e políticas públicas, $n^{o}$ 13. IPEA, 1996. Disponível em: <http://www.ipea.gov.br/ppp/index.php/PPP/article/viewFile/137/139>. Acesso em: 01 de fevereiro de 2014.

GALBRAITH, J.K. Obra Esencial. Malaga: Critica, 2002.

GASPAR, J. G. Araguaína e sua região: saúde como reforço da polarização. Recife: UFPE, 2002. 
GOIÁS. Lei n. 801, de dezembro de 1887 Disponível em: < http://www.casacivil.go.gov.br/post/ver/155258/criacao-dos-municipios.>. Acesso em: 22 de fevereiro de 2014.

GONÇALVES, C. O progresso em discussão: a construção imaginaria da BR-153 no discurso dos pioneiros de Araguaína. Araguaína: UFT, 2009. Trabalho de Conclusão de Curso TCC.

HAESBAERT, R. Da Desterritorialização à Multiterritorialidade. In: Encontro de Geógrafos da América Latina, 10, 2006, São Paulo. Anais... São Paulo: Universidade de São Paulo, 2006.

HOFFMAN, R. Estatística para Economistas. 4.ed. São Paulo: Pioneira Thomson Learning, 2001.

IBGE - Instituto Brasileiro de Geografia e Estatística. Censo Industrial de 1960. Rio de Janeiro: Biblioteca do IBGE, 1960.

IBGE - Instituto Brasileiro de Geografia e Estatística. Dados Estatísticos do Produto Interno Bruto, 12 dezembro 2013.2 Disponível em: <http://www.ibge.gov.br/home/estatistica/indicadores/pib/defaultcnt.shtm>. Acesso em: 16 de dezembro de 2013.

IBGE - Instituto Brasileiro de Geografia e Estatística. Portal eletrônico: Tocantins, 01 jun 2014. Disponível em: <http://www.cidades.ibge.gov.br/xtras/uf.php?lang=\&coduf=17\&search=tocantins>. Acesso em: 15 de dezembro de 2014.

ICHIHARA, S. M. (2007). O Uso Combinado dos Modelos de Insumo-Produto e Técnicas de Geoprocessamento. PhD thesis, Escola Superior de Agricultura "Luiz de Queiroz", Universidade de São Paulo.

INMETRO. Ministério do Desenvolvimento. Quadro Geral de Unidades de Medida no Brasil, 02 dez 2013. Disponível em:〈http://www.inmetro.gov.br/legislacao/rtac/pdf/RTAC002050.pdf $>$. Acesso em: 20 de julho de 2014.

IPEA. Portal eletrônico. 2014. Disponível em: <http://www.ipeadata.gov.br/>. Acesso em: 13 de junho de 2014.

ITPAC. $O$ portal da cidade de Araguaína - Tocantins. Disponível em: $<$ http://www.araguainanoticias.com.br/noticia/4480/itpac-lancara-curso-de-engenharia-deproducao-em-araguaina.html>. Acesso em: 19 de abril de 2013.

ITPAC, Araguaína Notícias. Disponível em: < http://www.itpac.br/arquivos/Revista/24/7.pdf.> . Acesso em: 22 de fevereiro de 2014.

JUNQUEIRA, G. Empreendedorismo, 2013. Disponível em: <http://www.administradores.com.br/artigos/negocios/empreendedorismo/21554/>. Acesso em: 08 de outubro de 2013.

KERSTENETZKY, C.L. Por que se importar com a desigualdade. 2002. Disponível em: < http://www.scielo.br/pdf/dados/v45n4/a04v45n4.pdf>. Acesso em: 09 de outubro de 2013.

KUBITSCHEK, J.). Discurso do Presidente da República. Biblioteca da Presidência da República, 2 fev 1960. Disponível em: <http://www.biblioteca.presidencia.gov.br/expresidentes/jk/discursos-1/1960/05.pdf/download>. Acesso em:13 de março de 2014. 
KUBISTCHECK, J. Por que Construí Brasília / Juscelino Kubistchek (Coleção Brasil 500 Anos). Brasília: Senado Federal, Conselho Editorial, 2000.

LESSA, C. et.al. Desenvolvimento Capitalista no Brasil - Ensaios sobre a crise. São Paulo: Brasiliense, 1982.

LEONTIEF, W. \& STROUT, A. (1963). Multiregional input-output analysis. In Barna, T., editor, Structural Interdependence and Economic Development, chapter 2, pages 119-50. St. Martin's Press, New York.

LUCAS, R. On the Mechanics of Economic Development. Jornaul of Monetary Economics, 1988.

LOPES, A.P. Araguaína-To: A Principal Cidade Econômica do Estado e a Periferia que Esconde as Vítimas do Trabalho Escravo por Dívida. Encontro Nacional de Grupos de Pesquisa - Engrup, 4. São Paulo, 2008.

MAZURAS, M. BR-010 Belém Brasília Uma Estrada Brasileira. São Caetano do Sul: Casa Editora Maior, 2013.

MDIC - Ministério do Desenvolvimento, Indústria e Comércio Exterior. Balança Comercial Brasileira: Dados Consolidados, 2013. Disponível em: <http://www.desenvolvimento.gov.br/arquivos/dwnl_1394635352.pdf >. Acesso em 16 de fevereiro de 2014.

MEC - Ministério da Educação. Índice de Desenvolvimento da Educação Básica - IDEB, 2013. Disponível em: <http://portal.mec.gov.br/index.php?option=com_content \& view=article \&id=180\&Itemid=336\& $\mathrm{msg}=1>$. Acesso em: 26 de março de 2013.

MELATTI, J. C. Índios e criadores. Rio de Janeiro: Universidade Federal do Rio de Janeiro, 1967. MELO, A. Dez Dias Na Belém - Brasília. Rio De Janeiro: Serviço de documentação S.P.V.E.A., 1960.

MILONE, P.C. Crescimento e Desenvolvimento Econômico: Teorias e Evidências Empíricas. In

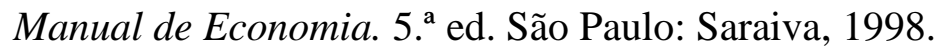

MILONE, P. C. et.al. Manual de Economia. 7.ed. São Paulo: Saraiva, 2009.

MIRA, E. C. IPEA - Instituto de Pesquisas Econômica Aplicada. 2011. Disponível em: <http://www.ipea.gov.br/code2011/chamada2011/pdf/area4/area4-artigo15.pdf>. Acesso em: 18 de fevereiro de 2011.

NETO, F. F. 150 anos de transportes no Brasil 1822/1972. Brasília: Ministério dos Transportes, 1974.

ODIER, L. Os Benefícios Econômicos das Realizações Rodoviárias. Tradução de Daltro Barbosa Leite. Rio de Janeiro: Apex Gráfica e Editora Ltda, 1970.

OLIVEIRA JR. , J.A. Planejamento, política de transportes e desenvolvimento regional. Fortaleza, IPLANCE, 1996.

OWEN, Wilfred. Estratégia para os Transportes. Tradução de David H. Hastings. São Paulo: Pioneira, 1975. 
PEIXOTO, J. B. Os transportes no atual desenvolvimento do Brasil. Rio de Janeiro: Biblioteca do Exército, 1977.

PINTO, A.; FREDES, C. Curso de Economia - Elementos de Teoria Econômica. Tradução de E.A.Cunha. 3.ed. Penha: Forum Editora, 1974.

PMPP - Prefeitura Municipal de Porto Nacional. Um breve histórico sobre a fundação e emancipação política de Porto Nacional, Fonte: Arquivo do Jornal O Pararelo 13. Disponível em: <http://www.portonacional.to.gov.br/pagina-cidade-um-breve-historico-sobre-a-fundacao-eemancipacao-politica-de-porto-nacional.html>. Acesso em: 16 de janeiro de 2015.

PNUD, P. Valores e Desenvolvimento Humano. Brasília: Ultra Digital Gráfica Editora Ltda, 2010. Disponível em: <http://www.pnud.org.br/HDR/Relatorios-Desenvolvimento-HumanoBrasil.aspx?indiceAccordion=2\&li=li_RDHBrasil>. Acesso em: 20 de dezembro de 2013.

PNUD, P. Organização das Nações Unidas, 2013. Disponível em: <http://www.pnud.org.br/Noticia.aspx?id=2583>. Acesso em: 20 de dezembro de 2013.

Portal de Agronegócio e Serviços Rurais. Disponível em: <http://www.mfrural.com.br/cidade/araguaina-to.aspx>. Acesso em: 16 de março de 2014.

REIS, R. Objetividade na Valorização da Amazônia. [S.1.: s.n.], 1948.

RIBEIRO, R. et.al. Plano Municipal de Água e Esgoto Prefeitura Municipal de Araguaína, Secretaria Municipal de Planejamento, Meio Ambiente, Ciência e Tecnologia, 2013. Disponível em: 〈http://araguaina.to.gov.br/portal/pdf/13.pdf>. Acesso em 20 de janeiro de 2013.

RODRIGUES, E. C. Crise nos Transportes. São Paulo: Editora Clássico - Científica, 1975.

RODRIGUES, L. A. O rio dos Tocantins. Rio de Janeiro: Serviço Gráfico IBGE, 1945.

SEBRAE. Estatística Econômica do Tocantins - Araguaína, 2 dez 2005. Disponível em: <http://201.2.114.147/bds/bds.nsf/5A55D11FA22C22B58325730D006F5B0A/\$File/NT00035B EE.pdf > . Acesso em: 21de janeiro de 2014.

SEPLAN, S.; IBGE. Tabela do Produto Interno Bruto a preços correntes, classificação, Valor Adicionado (VA) por sertor, PIB per capita e VA da Administração Pública, segundo municípios Tocantins - 2009.2 Disponível em: <http://www.seplan.to.gov.br/Arquivos/download/20111215142747-

pib_a_precos_correntes_va_por_setor_pib_per_capita_e_va_da_administracao_publica_segundo _municipios_2009.pdf >. Acesso em: 26 de junho de 2013.

SILVA, M. M. Geografia dos Transportes no Brasil. Rio de Janeiro: Serviço Gráfico do IBGE, 1949.

SILVA, R. A.). Dissertação de Mestrado. UECE, 31 dez 2012. Disponível em: <http://www.uece.br/mag/dmdocuments/roberto_silva.pdf>. Acesso em: 23 de fevereiro de 2014.

SOUSA, S. Belém-Brasília: Abrindo fronteiras no Norte Goiano 1958-1975. Goiânia: Universidade Federal de Goiás, 2002.

SOUZA, J. F.; CANDIOTO, R. A. Qualidade de vida e meio ambiente: um debate para mudanças socioeconômicas e políticas no Brasil. Caderno de Direito,17 jun 2013. Disponível em: <https://www.metodista.br/revistas/revistas-unimep/index.php/direito/article/viewArticle/1832>. Acesso em: 14 de abril de 2014. 
SUDAM. Histórico SUDAM. Disponível em: <http://www.sudam.gov.br/acessoainformacao/institucional/historico>. Acesso em: 26 de janeiro de 2015.

Transportes no Brasil. Disponível em: 〈http://www.transportes.gov.br/index/conteudo/id/60924〉. Acesso em: 05 de fevereiro de 2014.

UFT. Campus Universitário de Araguaína, maio 2014. Disponível em: <http://www.site.uft.edu.br/prograd/manual-do-aluno/campus-universitario-de-araguaina.html〉. Acesso em: 02 de maio de 2014.

VALEC. Portal eletrônico. Ações e Programas VALEC. EF-151 Ferrovia Norte-Sul trecho Açailândia/MA Palmas/TO, 26 maio 2014. Disponível em: <http://www.valec.gov.br/acoes_programas/FNSAcailandiaPalmas.php>. Acesso em: 14 de junho de 2014.

VALEC. Portal eletrônico. Ações e Programas VALEC. EF-334 Ferrovia de Integração Oeste Leste trecho Ilhéus/BA Caetité/BA Barreiras/BA Figueirópolis/TO, 26 maio 2014. Disponível em: $<$ http://www.valec.gov.br/acoes_programas/FerroviaIntegracaoOesteLeste.php>. Acesso em: 14 de junho de 2014.

VALVERDE, O.; DIAS, C. V. A Rodovia Belém-Brasília. Rio de Janeiro: Serviço Gráfico da Fundação IBGE, 1967.

VEIGA, José Eli da. Dossiê Teorias Socioambientais. Disponível em: <http://www.scielo.br/scielo.php?script=sci_arttext\&pid=S0103-40142010000100006〉. Acesso em: 25 de novembro de 2014.

VIANNA, G. Carta do Rio de Janeiro por um transporte mais seguro. Fórum Nacional de Segurança para o transporte de carga. Anuário NTC \& Logística No 3, 2006-2007.

VIEIRA, F. V., \& VERÍSSIMO, M. P. Crescimento econômico em economias emergentes selecionadas: Brasil, Rússia, Índia, China (BRIC) e África do Sul. Economia e sociedade, 2009. Disponível em: <http://www.scielo.br/scielo.php?script=sci_arttext\&pid=S010406182009000300004\&lng=pt\&nrm=iso\&tlng=pt $>$. Acesso em: 03 de março de 2014.

VIEIRA, R. Crescimento econômico no estado de São Paulo: uma análise espacial. São Paulo: Cultura Acadêmica, 2009. 